\title{
ATLAS CLIMÁTICO DE LOS ARCHIPIÉLAGOS DE CANARIAS, MADEIRA Y AZORES
}

\section{ATLAS CLIMÁTICO DOS ARQUIPÉLAGOS \\ DAS CANÁRIAS, DA MADEIRA E DOS AÇORES}

CLIMATE ATLAS OF THE ARCHIPELAGOS OF THE CANARY ISLANDS, MADEIRA AND THE AZORES

\section{ESPAÑA}





\section{ATLAS CLIMÁTICO DE LOS ARCHIPIÉLAGOS DE CANARIAS, MADEIRA Y AZORES}

TEMPERATURA DEL AIRE Y PRECIPITACIÓN (1971-2000)

\section{ATLAS CLIMÁTICO DOS ARQUIPÉLAGOS DAS CANÁRIAS, DA MADEIRA E DOS AÇORES}

TEMPERATURA DO AR E PRECIPITAÇÃO (1971-2000)

\section{CLIMATE ATLAS OF THE ARCHIPELAGOS OF THE CANARY ISLANDS, MADEIRA AND THE AZORES}

AIR TEMPERATURE AND PRECIPITATION (1971-2000)
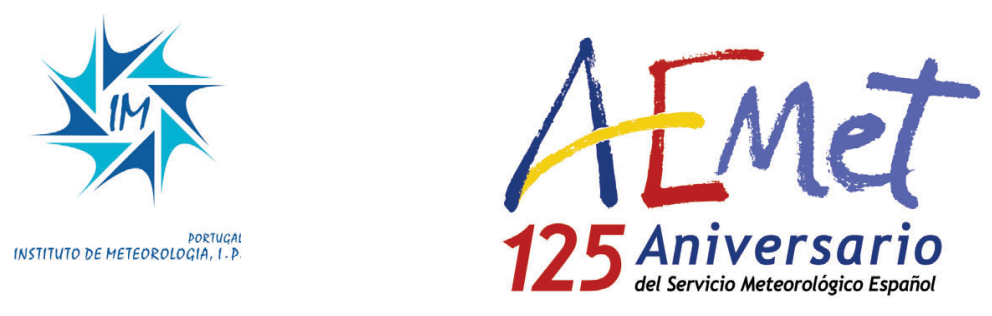
El presente Atlas ha sido elaborado por el Departamento de Producción de la Agencia Estatal de Meteorología de España (Área de Climatología y Aplicaciones Operativas) y por el Departamento de Meteorologia e Clima, Instituto de Meteorologia de Portugal (Divisão de Observação Meteorológica e Clima).

El tratamiento de interpolación y el cartografiado de la precipitación y temperatura del archipiélago de Canarias y la clasificación climática de Köppen de Canarias, Madeira y Azores han sido realizados por Andrés Chazarra Bernabé. El tratamiento de interpolación y el cartografiado de la precipitación y temperatura de los archipiélagos de Madeira y Azores han sido realizados por Sofia Cunha y Álvaro Silva.

Los cuadros y tablas de valores normales de precipitación y temperatura de Canarias han sido confeccionados por Celia Flores Herráez. Los cuadros y tablas de valores normales de precipitación y temperatura de Madeira y Azores han sido confeccionados por Vanda Pires, Jorge Marques, Fernanda Carvalho y Luísa Mendes.

Los textos han sido redactados por Antonio Mestre Barceló, Andrés Chazarra Bernabé, Vanda Pires, Sofia Cunha, Álvaro Silva, Jorge Marques, Fernanda Carvalho, Manuel Mendes y Jorge Neto.

Se ha contado con la colaboración del personal de la Delegación Territorial de la Agencia Estatal de Meteorología en Canarias y del Centro de Investigación Atmosférica de Izaña en la elaboración de los mapas y tablas del archipiélago canario. Este trabajo ha contado también con la colaboración de los delegados regionales del IM en las regiones autónomas de Madeira (Victor Prior) y de las Azores (Diamantino Henriques).

La coordinación técnica del Atlas ha sido llevada a cabo por Antonio Mestre Barceló y Luís Filipe Nunes.

La coordinación de relaciones bilaterales AEMET-IM para el proyecto ha sido llevada a cabo por Gemma Sánchez Fernández y Carlos Direitinho Tavares.

La coordinación de la edición de la publicación ha sido llevada a cabo por Miguel Ángel García Couto de la Unidad de Documentación de AEMET.

O presente Atlas foi elaborado pelo Departamento de Producción da Agência Estatal de Meteorologia de Espanha (Área de Climatología y Aplicaciones Operativas) e pelo Departamento de Meteorologia e Clima (Divisão de Observação Meteorológica e Clima), do Instituto de Meteorologia - Portugal.

A interpolação e a cartografia da temperatura e da precipitação no arquipélago das Canárias, assim como a classificação de Köppen das Canárias, da Madeira e dos Açores, foram realizados por Andrés Chazarra. A interpolação e a cartografia da temperatura e da precipitação dos arquipélagos da Madeira e dos Açores foram realizadas por Sofia Cunha e Álvaro Silva.

Os quadros e tabelas de valores normais de temperatura e de precipitação das Canárias foram elaborados por Celia Flores Herráez. Os quadros e tabelas de valores normais de temperatura e de precipitação da Madeira e dos Açores foram elaborados por Vanda Pires, Jorge Marques, Fernanda Carvalho e Luísa Mendes.

Os textos foram elaborados por Andrés Chazarra, Antonio Mestre Barceló, Vanda Pires, Sofia Cunha, Álvaro Silva, Jorge Marques, Fernanda Carvalho, Manuel Mendes e Jorge Neto.

Este trabalho contou com a colaboração do pessoal da Delegación Territorial da Agência Estatal de Meteorologia nas Canárias e do Centro de Investigación Atmosférica de Izanha, na elaboraç̃o dos mapas e tabelas do arquipélago das Canárias. Este trabalho contou também com a colaboração dos delegados regionais do IM nas regiões autónomas da Madeira (Victor Prior) e dos Açores (Diamantino Henriques).

A coordenação técnica do Atlas foi da responsabilidade de Antonio Mestre Barceló e Luís Filipe Nunes.

A coordenação das relações bilaterais AEMET-IM, para o projecto, foi da responsabilidade de Gemma Sánchez e Carlos Direitinho Tavares.

A publicação foi da responsabilidade Miguel Ángel García Couto da Unidad de Documentación da AEMET.

This Atlas has been produced by the Production Department of the State Meteorological Agency of Spain (Climatology and Operative Applications Section) and by the Department of Meteorology and Climatology of the Institute of Meteorology, Portugal (Divisão de Observação Meteorológica e Clima).

The interpolation processing and mapping of temperature and precipitation of the Canary Islands, as well as the Köppen classification in the archipelagos of the Canary Islands, Madeira and the Azores, have been carried out by Andrés Chazarra. The interpolation processing and mapping of temperature and precipitation of the archipelagos of Madeira and the Azores have been carried out by Sofia Cunha and Álvaro Silva.

The charts and tables of normal values of temperature and precipitation in the Canary Islands have been drawn up by Celia Flores Herráez. The charts and tables of normal values of temperature and precipitation in Madeira and the Azores have been drawn up by Vanda Pires, Jorge Marques, Fernanda Carvalho and Luísa Mendes.

The texts have been written by Andrés Chazarra, Antonio Mestre Barceló, Vanda Pires, Sofia Cunha, Álvaro Silva, Jorge Marques, Fernanda Carvalho, Manuel Mendes and Jorge Neto.

Staff of Territorial Delegation of the State Meteorological Agency and of the Izaña Atmospheric Research Centre has collaborated in the production of the charts and tables of the canarian archipelago. Regional delegates of the IM in the autonomous regions of Maderia (Victor Prior) and the Azores (Diamantino Henriques) have also collaborated in this work.

Technical coordination of the Atlas has been carried out by Antonio Mestre Barceló and Luís Filipe Nunes.

Coordination of bilateral relations AEMET-IM for the project has been carried out by Gemma Sánchez and Carlos Direitinho Tavares.

The publication has been carried out by Miguel Ángel García Couto of the AEMET Documentation Unit.

Catálogo general de publicaciones oficiales:

https://cpage.mpr.gob.es

Edita: Agencia Estatal de Meteorología (C)

Ministerio de Agricultura, Alimentación y Medio Ambiente, 2012

(C) Instituto de Meteorologia de Portugal, 2012

NIPO: 281-12-006-X

https://doi.org/10.31978/281-12-006-X 


\section{ÍNDICE / ÍNDICE / TABLE OF CONTENTS}

PRÓLOGO

PRÓLOGO

FOREWORD.

PRESENTACIÓN

APRESENTAÇÃO

PRESENTATION

INTRODUCCIÓN/SUMARIO

INTRODUÇÃO/SUMÁRIO

INTRODUCTION/SUMMARY

1. CLIMA

1. CLIMA

1. CLIMATE

1.1. CLASIFICACIÓN DE KÖPPEN PARA CANARIAS, MADEIRA Y AZORES

1.1. CLASSIFICAÇÃO DE KÖPPEN: CANÁRIAS, MADEIRA E AÇORES

1.1. KÖPPEN CLIMATE CLASSIFICATION FOR CANARY ISLANDS, MADEIRA AND AZORES ..

2. OBSERVACIONES METEOROLÓGICAS

2. OBSERVAÇÕES METEOROLÓGICAS

2. METEOROLOGICAL OBSERVATIONS

2.1. OBSERVACIONES EN CANARIAS

2.1. OBSERVAÇÕES NAS CANÁRIAS

2.1. OBSERVATIONS IN THE CANARY ISLANDS

2.2. OBSERVACIONES EN MADEIRA

2.2. OBSERVAÇÕES NA MADEIRA

2.2. OBSERVATIONS IN MADEIRA

2.3. OBSERVACIONES EN AZORES

2.3. OBSERVAÇÕES NOS AÇORES

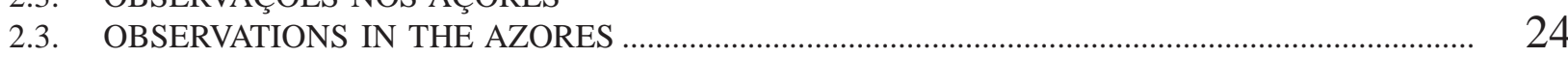

3. METODOLOGÍA

3. METODOLOGIA

3. METHODOLOGY

3.1. NORMALES CLIMATOLÓGICAS

3.1. NORMAIS CLIMATOLÓGICAS

3.1. CLIMATE NORMALS

3.2. CARTOGRAFÍA

3.2. CARTOGRAFIA

3.2. CARTOGRAPHY

4. TEMPERATURA

4. TEMPERATURA

4. TEMPERATURE

4.1. ARCHIPIÉLAGO DE CANARIAS

4.1. ARQUIPÉLAGO DAS CANÁRIAS

4.1. ARCHIPELAGO OF THE CANARY ISLANDS

4.2. ARCHIPIÉLAGOS DE MADEIRA Y AZORES

4.2. ARQUIPÉLAGOS DA MADEIRA E DOS AÇORES

4.2. ARCHIPELAGOS OF MADEIRA AND THE AZORES

5. PRECIPITACIÓN

5. PRECIPITAÇÃO

5. PRECIPITATION

5.1. ARCHIPIÉLAGO DE CANARIAS

5.1. ARQUIPÉLAGO DAS CANÁRIAS

5.1. ARCHIPELAGO OF THE CANARY ISLANDS ...

61

5.2. ARCHIPIÉLAGOS DE MADEIRA Y AZORES

5.2. ARQUIPÉLAGOS DA MADEIRA E DOS AÇORES

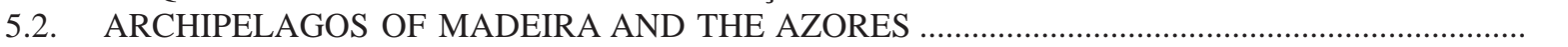

REFERENCIAS

REFERÊNCIAS

REFERENCES 



\section{PRÓLOGO}

Hace ya un año tuve el honor de presentar la primera publicación del Atlas Climático Ibérico como resultado de la fructífera cooperación desde hace ya varios años que llevan a cabo los servicios meteorológicos nacionales de España y Portugal. Aquella primera publicación recogía los mapas y datos de las variables de temperatura y precipitación para la Península Ibérica y, por continuidad geográfica, del archipiélago de Baleares, con el objetivo de presentar una sinopsis climática de esa región geográfica que pueda servir como instrumento para el estudio del Clima de nuestra región.

Dicha publicación ha contado con una gran acogida entre el público en general. Y además, diferentes entidades públicas y universitarias han solicitado la información de las capas SIG climatológicas que se generaron para el uso en sus estudios y aplicaciones, viniendo a corroborar uno de sus objetivos principales que era dar esta información como servicio climático para la sociedad.

Ya en aquella ocasión remarcaba que este era un proyecto "vivo" y que entre los principales objetivos de las siguientes publicaciones estaba estudiar también el espacio geográfico insular atlántico común, que son los archipiélagos de Canarias, Madeira y Azores.

Así que, en esta ocasión tengo el honor de presentar este Atlas Climático de los archipiélagos de Canarias, Madeira y Azores (1971-2000). Esta es una publicación paralela al Atlas Climático Ibérico, publicado hace un año, con la misma estructura y variables aunque para un espacio geográfico insular de características totalmente diferentes.

Quiero resaltar ante todo que esta publicación no sería posible sin la estrecha colaboración de los servicios meteorológicos ibéricos, la Agencia Estatal de Meteorología y el Instituto de Meteorología de Portugal enmarcada dentro del Centro Ibérico de Servicios del Clima (CISCLIMA) en 2010. Nuestros climatólogos y científicos trabajan juntos con el objetivo común de conocer nuestro Clima y dar servicios climáticos que reclama la sociedad actual.

\section{PRÓLOGO}

Há já um ano tive a honra de apresentar a primeira publicação do Atlas Climático Ibérico em resultado da frutífera cooperação de há vários anos entre os serviços meteorológicos nacionais da Espanha e de Portugal. Aquela primeira publicação recolhia os mapas e dados das variáveis de temperatura e precipitação da Península Ibérica e, por continuidade geográfica, do arquipélago das Baleares, com o objectivo de apresentar uma sinopse climática dessa região geográfica que possa servir como instrumento para o estudo do Clima da nossa região.

Tal publicação contou com um bom acolhimento pelo público em geral. E, além disso, diferentes entidades públicas e universitárias solicitaram as informações climatológicas das camadas SIG que foram criadas para as usarem nos seus estudos e aplicações, o que veio corroborar um dos seus objectivos principais que consistia em dar estas informações como serviço climático para a sociedade.

Já naquela ocasião acentuava que este era um projecto "vivo" e que entre os principais objectivos das publicações seguintes se encontrava igualmente o estudo do espaço geográfico insular atlântico comum, que é constituído pelos arquipélagos das Canárias, Madeira e Açores.

Desta forma, nesta ocasião tenho a honra de apresentar este Atlas Climático dos arquipélagos das Canárias, da Madeira e dos Açores (1971-2000). Esta é uma publicação paralela ao Atlas Climático Ibérico, publicado há um ano, com a mesma estrutura e variáveis, embora para um espaço geográfico insular de características totalmente diferentes.

Quero realçar em primeiro lugar que esta publicação não seria possível sem a estreita colaboração dos serviços meteorológicos ibéricos -Agência Estatal de Meteorologia e Instituto de Meteorologia de Portugal- enquadrada no Centro Ibérico de Serviços do Clima (CISCLIMA) em 2010. Os nossos climatologistas e cientistas trabalham juntos com o objectivo comum de conhecerem o nosso Clima e prestarem serviços climáticos reclamados pela sociedade actual.

\section{FOREWORD}

A year ago I had the honour of presenting the first publication of the Iberian Climate Atlas as a result of years of fruitful cooperation between the national weather services of Spain and Portugal. That first publication contained the maps and data relating to temperature and precipitation variables for the Iberian Peninsula and, for geographical continuity, the archipelago of the Balearic Islands, in order to present an overview of the climate of that geographical region so that it might serve as a tool to study the Climate in our region.

That publication has been well received by the general public. Furthermore, various public and university bodies have requested the information from the resulting climate GIS layers for use in their research and applications, thus achieving one of its main objectives, which was to provide this information as a climate service to society.

During that time I commented that this was a "live" project and that the main objectives of the subsequent publications would include also studying the common insular geographic area of the Atlantic which comprises the archipelagos of the $\mathrm{Ca}$ nary Islands, Madeira and the Azores.

Therefore, on this occasion I have the honour of presenting this Climate Atlas of the archipelagos of the Canary Islands, Madeira and the Azores (19712000). This publication is parallel to the Iberian Climate Atlas which was published last year, with the same structure and variables, but for an insular geographical area with completely different characteristics.

Above all I must emphasise that this publication would not have been possible without the close cooperation between the Iberian weather services, the Spanish State Meteorological Service and the Portuguese Meteorological Institute, within the framework of the Iberian Centre for Climate Services (CISCLIMA) in 2010. Our climatologists and scientists work together with the common objective of gaining knowledge about our Climate and to provide the climate services which society currently requires.

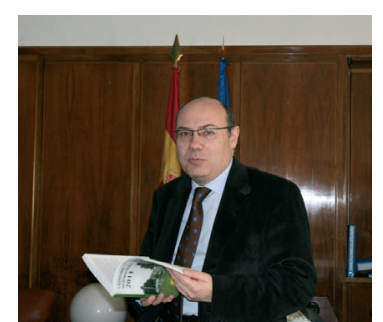

Ricardo García Herrera Presidente de AEMET
Ricardo García Herrera Presidente da AEMET
Ricardo García Herrera President of AEMET 



\section{PRESENTACIÓN}

Como continuación de la publicación del Atlas Climático Ibérico, en marzo de 2011, que incluía las islas Baleares, ahora se publica, de acuerdo con lo previsto, el Atlas climático referente a la temperatura y precipitación, en el período 1971-2000, de los archipiélagos atlánticos de España y Portugal, ampliando la información climática a todas las regiones de ambos países.

Este Atlas es más bien el resultado de la cooperación existente en los diversos ámbitos del área de responsabilidad de los Servicios Meteorológicos Nacionales de Portugal y España, la AEMET y el IM, concretamente en el área de los servicios climáticos, enmarcada en las actividades del CISCLIMA (Centro Ibérico de los Servicios de Clima), establecido por los dos Servicios en 2010 con el objetivo de desarrollar en las dos instituciones productos y servicios que respondan a las necesidades de ambos países en el área del clima.

Siendo el clima un recurso fundamental para el desarrollo de las sociedades, este Atlas, resultado del análisis conjunto de los resultados obtenidos en las redes de las dos instituciones por los investigadores y técnicos de la AEMET y del IM, al caracterizar el clima de los archipiélagos incluidos en este, es una herramienta esencial para la optimización del aprovechamiento de los recursos climáticos en su desarrollo socioeconómico, permitiendo a los encargados tomar decisiones políticas y económicas y a otros usuarios, planificar sus inversiones y sus actividades teniendo en cuenta las condiciones medias existentes, así como la posibilidad de registrar valores extremos que podrían originar desastres naturales.

Siendo los cambios climáticos, por los impactos esperados en la actividad humana, una preocupación creciente de las sociedades, el conocimiento de la evolución del clima emerge como una necesidad cada vez más presente, para poder tomar medidas de adaptación a tiempo, en concreto en inversiones a medio y largo plazo.

Asimismo, será de gran importancia la caracterización del clima reflejada en este Atlas como situación de referencia para el seguimiento de los cambios climáticos y para el desarrollo de escenarios del clima futuro, por lo que esta información se pone a disposición de la investigación científica para mejorar el conocimiento y anticipación de las condiciones climáticas que podrían influir, positiva y negativamente, en los ecosistemas del espacio ibérico.

Adérito Vicente Serrão Presidente del Consejo Directivo (IM, I.P.)

\section{APRESENTAÇÃO}

Na sequência da publicação do Atlas Climático Ibérico, em Março de 2011, que incluía as ilhas Baleares, é agora editado, de acordo com o previsto, o Atlas climático referente à temperatura e precipitação, no período 1971-2000, dos arquipélagos atlânticos de Espanha e Portugal, estendendo a informação climática a todas as regiões dos dois países.

Este Atlas é mais um resultado da cooperação existente nos vários domínios da área de responsabilidade dos Serviços Meteorológicos Nacionais de Portugal e Espanha, a AEMET e o IM, nomeadamente na área dos serviços de clima, enquadrada nas atividades do CISCLIMA (Centro Ibérico dos Servicos de Clima), estabelecido pelos dois Serviços em 2010 com o objetivo de desenvolver nas duas instituições produtos e serviços que respondam às necessidades dos dois países na área do clima.

Sendo o clima um recurso fundamental para o desenvolvimento das sociedades, este Atlas, resultado da análise conjunta dos resultados obtidos nas redes das duas instituições pelos investigadores e técnicos da AEMET e do IM, ao caracterizar o clima dos arquipélagos nele incluídos, é ferramenta essencial para a otimização do aproveitamento dos recursos climáticos no seu desenvolvimento socioeconómico, permitindo aos decisores políticos e económicos e outros utilizadores, planear os seus investimentos e as suas atividades tendo em conta as condições médias existentes, bem como a possibilidade de ocorrência de valores extremos que poderão ser responsáveis por desastres naturais.

Sendo as alterações climáticas, pelos impactos esperados na atividade humana, uma preocupação crescente das sociedades, o conhecimento da evolução do clima emerge como uma necessidade cada vez mais presente, por forma a permitir a tomada tempestiva de medidas de adaptação, designadamente em investimentos de médio e longo prazo.

Igualmente será de extrema importância a caracterização do clima refletida neste Atlas como situação de referência para o acompanhamento das alterações climáticas e para desenvolvimento de cenários do clima futuro, pelo que esta informação é colocada ao dispor da investigação científica para um melhor conhecimento e antecipação das condições climáticas que, positiva e negativamente, serão suscetíveis de influenciar os ecosistemas no espaço ibérico.

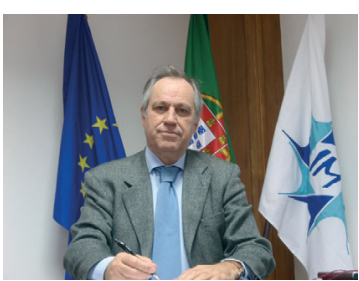

Adérito Vicente Serrão

Presidente do Conselho Directivo (IM, I.P.)

\section{PRESENTATION}

Following the publication of the Iberian Climate Atlas, in March 2011, which included the Balearic Islands, the Climate Atlas on temperature and precipitation is now published as predicted. It covers the period between 1971-2000 of the Atlantic archipelagos of Spain and Portugal, expanding the climatic information for all regions of the two countries.

This Atlas is more the result of existing corporation across different areas of responsibility of the State Meteorological Services of Portugal and Spain, the AEMET and the IM, particularly within the area of climate services, framed within the activities of the CISCLIMA (Iberian Centre for Climate Services). These were established by the two services in 2010 with the aim of developing, within the two institutions, products and services that respond to the needs of the two countries within the area of climate.

Since the climate is a fundamental resource for the development of societies, this Atlas, the result of joint analysis of the results obtained in the networks of the two institutions by the researchers and technicians of AEMET and IM, by characterising the climate of the archipelagos that it includes, is an essential tool for the optimisation of the use of climatic resources in its socio-economic development. It allows political and economic policy makers, as well as other users, to plan their investments and activities, taking into account the average conditions that exist as well as the possibility of extreme values that may be responsible for natural disasters.

Since climate change, with its expected impact on human activity, is a growing concern among societies, knowledge of climate evolution is emerging as an ever more present need in order to allow timely adaptation measures to be taken, in particular with regard to medium and long-term investment.

Likewise, it will be of great importance to characterise the climate shown in this Atlas as a benchmark for monitoring climate change and for the development of future climate scenarios. Therefore, this information is placed at the disposal of scientific research for a better understanding and anticipation of climatic conditions which, both positively and negatively, will be susceptible to influencing the ecosystems of the Iberian Peninsula.

Adérito Vicente Serrão President of the Board (IM, I.P.) 



\section{INTRODUCCIÓN/SUMARIO}

El Atlas Climático de los archipiélagos de Canarias, Madeira y Azores surge a partir de la primera edición del Atlas Ibérico, dedicado a los territorios continentales de Portugal y España e islas Baleares y editado en marzo de 2011, en el marco de la cooperación del Centro Ibérico de Servicios del Clima (CISCLIMA).

Esta nueva edición del Atlas Ibérico, a semejanza de la edición anterior, pretende describir las principales características climatológicas de los territorios de Portugal y de España, esta vez los territorios de las islas de Madeira y de las Azores (Portugal) y de las Canarias (España).

La información básica utilizada en la elaboración del Atlas ha sido, por norma general, la de las normales climatológicas (valores medios) correspondientes al período 1971-2000, según las recomendaciones de la Organización Meteorológica Mundial (OMM), que ha establecido normas para elaborar y publicar Atlas Climatológicos, recomendando que satisfagan las necesidades de un gran número de usuarios y que sirvan también de base a la elaboración de atlas regionales.

Las normales climatológicas se utilizan como información básica en la clasificación del clima de una determinada región, siendo una valiosa información climática que permite, por un lado, apoyar el desarrollo socioeconómico, como la planificación urbana, la agricultura y los bosques, la energía y los transportes, el turismo y el medio ambiente, entre otros, y fundamentando decisiones políticas y de gestión en diversos ámbitos; y por otro lado, es un importante instrumento de referencia para el seguimiento de la variabilidad y de las alteraciones climáticas.

Los elementos climáticos que constan en este volumen son la Temperatura del Aire y la Precipitación, basándose en los datos de observación en estaciones meteorológicas y estaciones pluviométricas de las redes nacionales de Portugal, en Madeira y en las Azores, y España, en las Canarias. La cartografía de los valores medios de la temperatura del aire y de la precipitación se efectúa a través de Sistemas de Información Geográfica (SIG).

Para complementar los mapas de temperatura y precipitación se presenta también la cartografía y clasificación climática de Köppen de las citadas regiones, así como tablas y gráficos de temperatura y de precipitación.

En la Figura 1 se presenta el contexto geográfico de los archipiélagos de las Azores, de Madeira y de las Canarias y en la Figura 2 se presenta su composición y las denominaciones de las respectivas islas y capitales.

Para cada elemento climático, temperatura del aire y precipitación, se presentan los siguientes mapas:

Media mensal, estacional y anual de la temperatura media.

- Media mensual, estacional y anual de la temperatura máxima.

a Media mensual, estacional y anual de la temperatura mínima.

\section{INTRODUÇÃO/SUMÁRIO}

O Atlas Climático dos arquipélagos das Canárias, da Madeira e dos Açores, surge no seguimento da primeira edição do Atlas Ibérico, dedicado aos territórios continentais de Portugal e Espanha e ilhas Baleares e editado em março de 2011, no âmbito da cooperação do Centro Ibérico de Serviços do Clima (CISCLIMA).

Esta nova edição do Atlas Ibérico à semelhança da edição anterior, pretende descrever as principais características climatológicas dos territórios de Portugal e de Espanha, desta feita os territórios das ilhas da Madeira e dos Açores (Portugal) e das Canárias (Espanha).

A informação de base utilizada na elaboração do Atlas foi, em regra, a das normais climatológicas (valores médios) correspondentes ao período 1971-2000, segundo as recomendações da Organização Meteorológica Mundial (OMM), a qual estabeleceu regras com vista à elaboração e publicação de Atlas Climatológicos, recomendando que estes satisfaçam as necessidades de grande número de utilizadores e ainda que sirvam de base à elaboração de atlas regionais.

As normais climatológicas são utilizadas como informação de base na classificação do clima de uma determinada região, sendo uma valiosa informação climática que permite, por um lado, o apoio ao desenvolvimento socioeconómico, como o planeamento urbano, a agricultura e florestas, a energia e transportes, o turismo e o ambiente, entre outras e sustentando decisões políticas e de gestão em vários domínios; e por outro lado é um importante instrumento de referência para o acompanhamento da variabilidade $\mathrm{e}$ das alterações climáticas.

Os elementos climáticos que constam neste volume são a Temperatura do ar e a Precipitação, tendo por base os dados de observação em estações meteorológicas e postos udométricos das redes nacionais de Portugal, na Madeira e nos Açores e Espanha, nas Canárias. A cartografia dos valores médios da temperatura do ar e da precipitação é efetuada através de Sistemas de Informação Geográfica (SIG).

Para complementar os mapas de temperatura e precipitação apresenta-se também o mapeamento a classificação climática de Koppen das referidas regiões, assim como tabelas e gráficos de temperatura e de precipitação.

Na Figura 1 apresenta-se o enquadramento geográfico dos arquipélagos dos Açores, da Madeira e das Canárias e na Figura 2 apresenta-se a constituição dos mesmos e as designações das respetivas ilhas e capitais.

Para cada elemento climático, temperatura do ar e precipitação, apresentam-se as seguintes cartas:

a Média mensal, sazonal e anual da temperatura média.

- Média mensal, sazonal e anual da temperatura máxima.

口 Média mensal, sazonal e anual da temperatura mínima.

\section{INTRODUCTION/SUMMARY}

The Climate Atlas of the archipelagos of the Canary Islands, Madeira and the Azores follows on from the first edition of the Iberian Atlas. It focuses on the mainland territories of Portugal and Spain and the Balearic Islands and was published in March 2011, with the cooperation of the Iberian Centre for Climate Services (CISCLIMA).

This new edition of the Iberian Atlas is similar to the previous edition, which intended to describe the main climatological features of the territories of Portugal and Spain, this time it covers the territories of Madeira and the Azores (Portugal) and the Canary Islands (Spain).

The basis of the information used in preparing the Atlas was, as a rule, the climatological normals (average values) corresponding to the period 19712000 , in accordance with the recommendations of the World Meteorological Organization (WMO), which established rules for the preparation and publication of Climate Atlases. It recommended that they meet the needs of a large number of users and even serve as a basis for developing regional atlases.

The climatological normals are used as background information in the classification of the climate of a specific region. On the one hand it is valuable information that allows support for socio-economic development, such as urban planning, agriculture and forestry, energy and transport, tourism and the environment, among others. It also supports policy making and management in various fields. And on the other hand, it is an important reference tool for the monitoring of variability and climate change.

The climatic elements used in this volume are air temperature and precipitation, based on observation data from meteorological stations and udometer posts of the national networks in Portugal, Madeira and the Azores, and in Spain, the Canary Islands. The mapping of the average values of air temperature and precipitation is achieved via Geographic Information Systems (GIS).

In order to supplement the temperature and precipitation maps the Köppen climate classification map of the abovementioned regions is also shown, as well as tables and graphs showing temperature and precipitation.

Figure 1 shows the geographical setting of the archipelagos of the Azores, Madeira and the Canary Islands and Figure 2 shows their constitution and the names of the respective islands and capitals.

For each climatic element, air temperature and precipitation, the following maps are shown:

$\square$ Annual, seasonal and monthly average for mean air temperature.

- Annual, seasonal and monthly average for maximum air temperature.

Annual, seasonal and monthly average for minimum air temperature. 
$\square$ Media anual del número de días con temperatura:

- mínima $\leq 0{ }^{\circ} \mathrm{C}$ (días de helada)

- mínima $\geq 20^{\circ} \mathrm{C}$ (noches tropicales)

- máxima $\geq 25^{\circ} \mathrm{C}$ (días cálidos)

$\square$ Media de la precipitación total mensual y anual.

- Media anual del número de días con precipitación:

- $\geq 0,1 \mathrm{~mm}$

- $\geq 1 \mathrm{~mm}$

- $\geq 10 \mathrm{~mm}$

- $\geq 30 \mathrm{~mm}$
- Média anual do número de dias com temperatura:

- mínima $\leq 0{ }^{\circ} \mathrm{C}$ (dias de geada)

- mínima $\geq 20{ }^{\circ} \mathrm{C}$ (noites tropicais)

- máxima $\geq 25^{\circ} \mathrm{C}$ (dias quentes)

$\square$ Média da precipitação total mensal e anual.

- Média anual do número de dias com precipitação:
- $\geq 0,1 \mathrm{~mm}$
- $\geq 1 \mathrm{~mm}$
- $\geq 10 \mathrm{~mm}$
- $\geq 30 \mathrm{~mm}$

- Annual average for the number of days regarding: - minimum air temperature $\leq 0{ }^{\circ} \mathrm{C}$ (frost days)

- minimum air temperature $\geq 20^{\circ} \mathrm{C}$ (tropical nights)

- maximum air temperature $\geq 25^{\circ} \mathrm{C}$ (hot days)

Monthly and annual average of total rainfall.

$\square$ Annual average for the number of days with precipitation amounts:

- $\geq 0,1 \mathrm{~mm}$

- $\geq 1 \mathrm{~mm}$

- $\geq 10 \mathrm{~mm}$

- $\geq 30 \mathrm{~mm}$

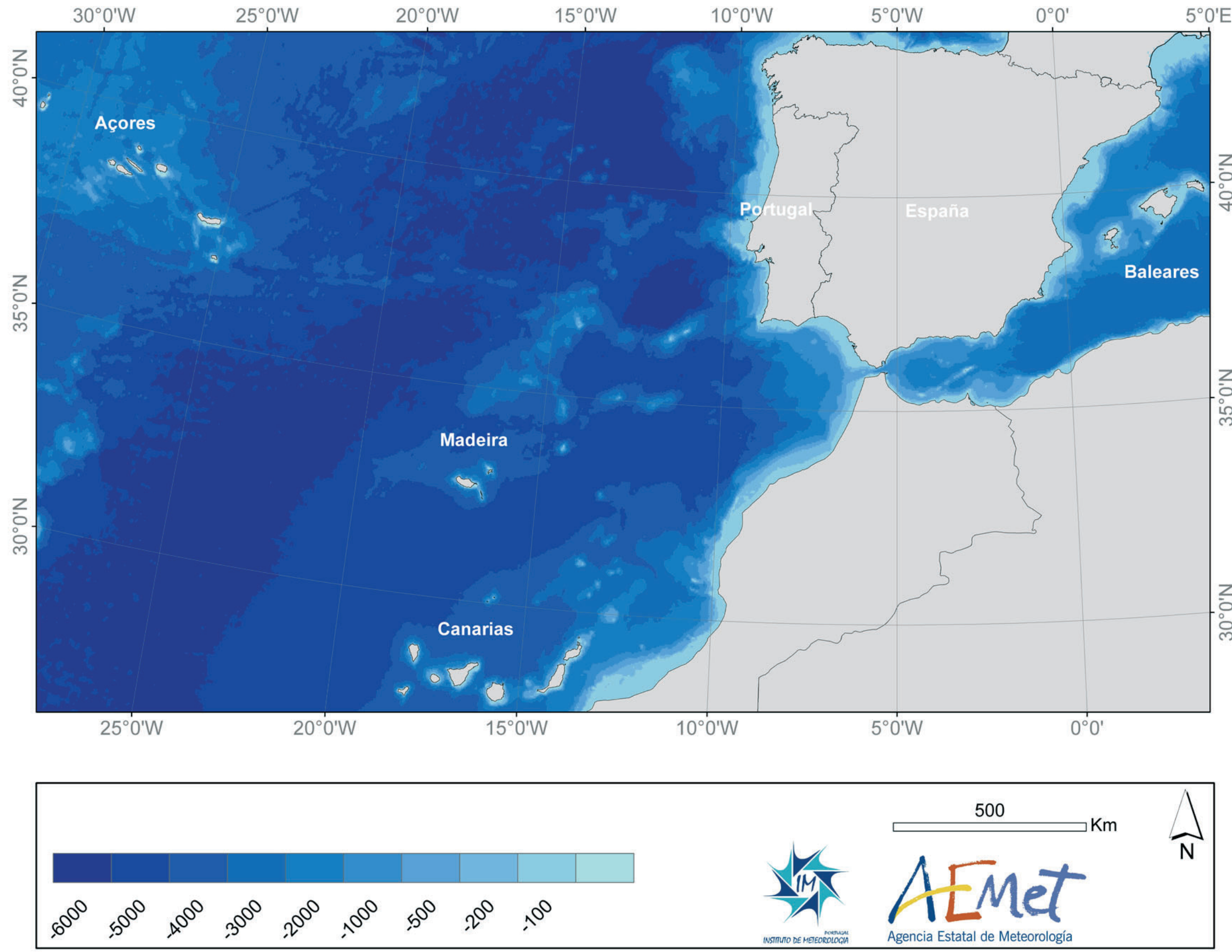

Fig. 1. Situación geográfica de los archipiélagos de Azores, Madeira y Canarias.

Enquadramento geográfico dos arquipélagos dos Açores, da Madeira e das Canárias.

Geographical setting of the archipelagos of the Azores, Madeira and the Canary Islands. 


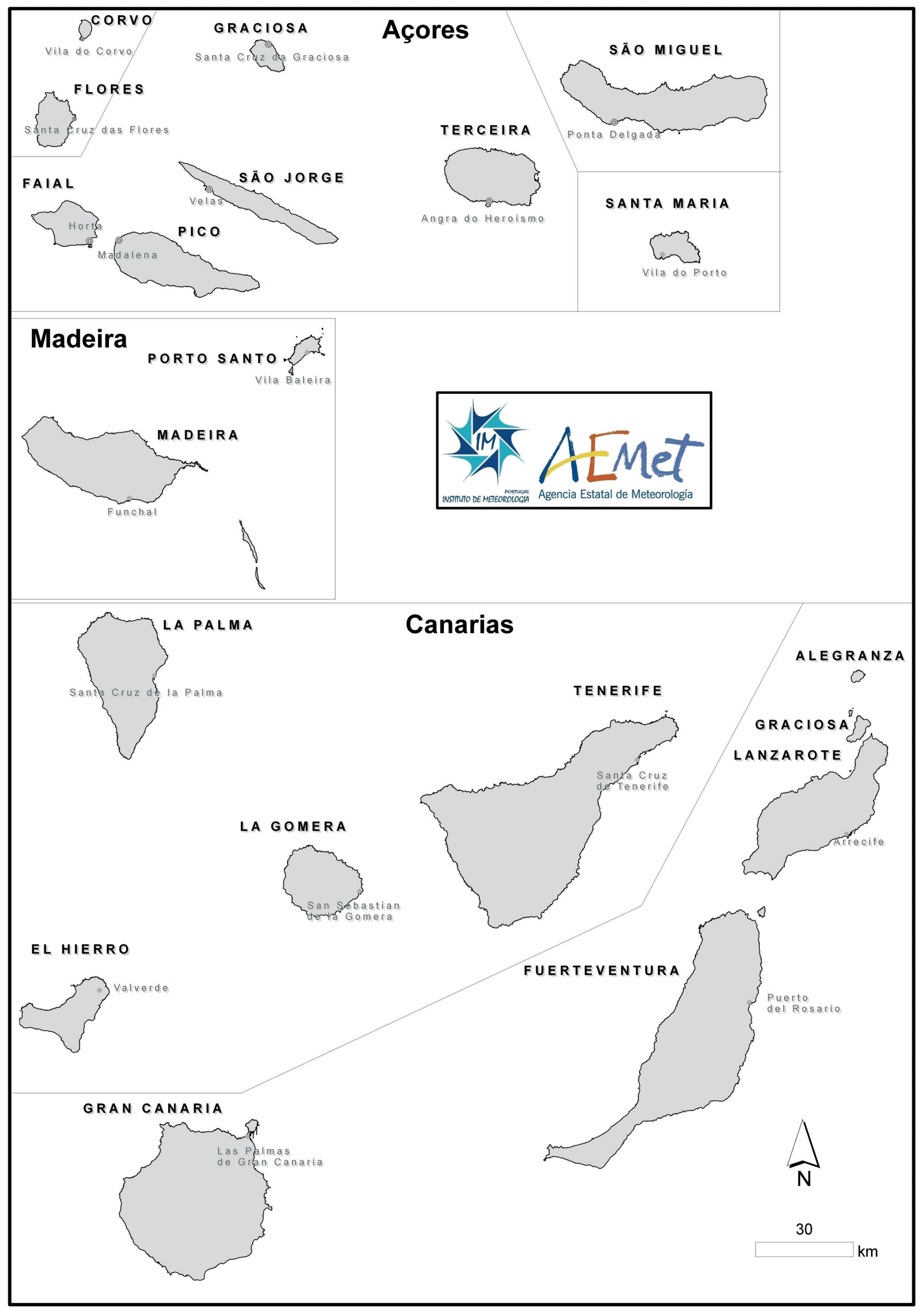

Fig. 2. Composición de los archipiélagos de Azores, Madeira y Canarias.

Constituição dos arquipélagos dos Açores, da Madeira e das Canárias.

Constitution of the archipelagos of the Azores, Madeira and the Canary Islands. 



\section{Clima}

El Clima corresponde a una síntesis del tiempo meteorológico asociada al conjunto de las condiciones meteorológicas, en un momento y lugar determinados. En la definición más común, el clima se refiere a las "condiciones medias del tiempo" y, más concretamente, a la descripción estadística en términos cuantitativos, de la media y de la variabilidad de las magnitudes relevantes, relativas a períodos de tiempo suficientemente largos.

El período de tiempo suficientemente largo adoptado por la OMM es de 30 años, período durante el cual se analizan los elementos climáticos, como la temperatura y la precipitación.

El clima de un lugar determinado puede variar en función del intervalo de tiempo utilizado y no es el mismo para un año, una década o un siglo. En la descripción cuantitativa del clima es necesario indicar el período (intervalo de tiempo) al que corresponden los valores numéricos presentados. De hecho, el clima varía con el tiempo y por eso no deben compararse climas utilizando valores correspondientes a intervalos de tiempo con períodos de años diferentes, o correspondientes al mismo número de años, pero en épocas diferentes.

De esta forma, en este Atlas, más que caracterizar el clima, se describe el estado climático que, en este caso concreto, se refiere al período 1971-2000.

\subsection{Clasificación de Köppen para Canarias, Madeira y Azores}

Para la delimitación de los distintos tipos de clima presentes en los archipiélagos de Canarias, Madeira y Azores se ha utilizado la clasificación climática de Köppen. A pesar de haber sido formulada hace cerca de cien años sigue siendo una de las clasificaciones más habitualmente empleada en estudios climatológicos en todo el mundo.

La clasificación de Köppen define distintos tipos de clima a partir de los valores medios mensuales de la precipitación y de la temperatura; para la delimitación de los distintos tipos de clima establece umbrales de temperatura y precipitación basados principalmente en su influencia sobre la distribución de la vegetación y la actividad humana (EsSENwANGER, 2001).

Originariamente formulada por Wladimir Köppen en 1918, ha experimentado sucesivas modificaciones por parte del propio Köppen y de otros climatólogos. En el presente Atlas climático se ha seguido el esquema propuesto por Köppen en su última revisión de 1936, conocido también como clasificación de Köppen-Geiger, con la única salvedad de la temperatura umbral que separa los tipos templado C y frío D, para la cual se ha escogido el valor de $0{ }^{\circ} \mathrm{C}$ propuesto por Russel, Trewartha, Critchfield y otros autores (Essenwanger, 2001) en lugar de los $-3{ }^{\circ} \mathrm{C}$ de la clasificación original. Este esquema es análogo al empleado en la clasificación actualizada a nivel mundial publicada recientemente por PeEL et aL. (2007).

\section{Clima}

O Clima corresponde a uma síntese do tempo meteorológico, que corresponde ao conjunto das condiçoes meteorológicas, num dado instante e num dado local. Na definição mais comum, o clima, refere-se às "condições médias do tempo" e, mais rigorosamente, à descrição estatística em termos quantitativos, da média e da variabilidade das grandezas relevantes, relativas a períodos de tempo suficientemente longos.

O período de tempo suficientemente longo adotado pela OMM é de 30 anos, período durante o qual se analisam os elementos climáticos, como a temperatura e a precipitação.

O clima de um dado local pode variar em função do intervalo de tempo utilizado e não é o mesmo para um ano, um decénio, ou um século. Na descrição quantitativa do clima é necessário indicar o período (intervalo de tempo) a que correspondem os valores numéricos apresentados. Com efeito, o clima varia com o tempo e por isso não devem compararse climas utilizando valores que correspondam a intervalos de tempo com períodos de anos diferentes, ou que, correspondam ao mesmo número de anos, mas em épocas diferentes.

Desta forma, neste Atlas, mais do que caracterizar o clima, descreve-se o estado climático que, neste caso concreto, se refere ao período 1971-2000.

\subsection{Classificação climática de Köppen: Canárias, Madeira e Açores}

Para a delimitação geográfica dos distintos tipos de clima nos arquipélagos dos Açores, da Madeira e das Canárias, utilizou-se a classificacão climática de Köppen. Esta classificação apesar de ter sido definida há cerca de 100 anos, continua a ser uma das classificações mais utilizadas em estudos climatológicos de todo o mundo.

A classificação de Köppen define distintos tipos de clima a partir dos valores médios mensais da precipitação e da temperatura. Para a delimitação dos diferentes climas estabelecem-se intervalos de temperatura e de precipitaç̃o baseados principalmente na sua influência sobre a distribuição da vegetação e da atividade humana (Essenwanger, 2001).

Originalmente formulada por Wladimir Köppen em 1900, a classificação de Köppen passou por sucessivas modificações pelo próprio Köppen e por outros climatologistas. À semelhança do atlas para a Península Ibérica e Baleares, neste atlas seguiu-se também o esquema proposto por Köppen na sua última revisão de 1936, conhecida também como a classificação de Köppen-Geiger, com a única ressalva de que o limite de temperatura que separa os climas temperados $\mathrm{C}$ e D, se escolheu como sendo $0{ }^{\circ} \mathrm{C}$, conforme proposto por Russel, Trewartha, Critchfield e outros autores (Essenwanger, 2001), em vez de $-3,0{ }^{\circ} \mathrm{C}$ utilizados na classificação original. Este esquema é igual ao utilizado na classificação atualizada a nível mundial, publicada recentemente por PeEL ET AL. (2007).

\section{Climate}

The climate corresponds to an overview of meteorological weather, which corresponds to meteorological conditions as a whole, at a given instant and in any given location. The most common definition, climate, refers to the "average weather conditions", and, more precisely, the statistical description in quantitative terms of the average and of the relevant variability, relating to sufficiently long periods of time.

The sufficiently long period of time adopted by the WMO is 30 years. This is the period during which climatic elements are analysed, such as temperature and precipitation.

The climate in a given location can vary depending on the time interval used and is not the same for a year, a decade or a century. In a quantitative description of climate it is necessary to indicate the period (time interval) to which the numerical values presented correspond. Indeed, the climate varies with time and therefore comparisons should not be made using values that correspond to intervals of time and periods of different years, or values that correspond to the same number of years, but at different times

Therefore, this Atlas, rather than simply characterising the climate, describes the climatic state which, in this specific case, refers to the period between 1971 and 2000 .

\subsection{Köppen climate classification for Canary Islands, Madeira and Azores}

For the geographical delimitation of the different types of climate in the archipelagos of the Azores, Madeira and the Canary Islands, the Köppen Climate Classification was used. Despite the fact that this classification has been established for around 100 years, it remains one of the most used classifications in climatological studies worldwide.

The Köppen Climate Classification defines different types of climate using average monthly precipitation and temperature. In order to define the different climates, ranges of temperature and precipitation are established based primarily on their influence on the distribution of vegetation and human activity (ESSENWANGER, 2001).

Originally formulated by Wladimir Köppen in 1900, the Köppen classification underwent successive modifications by Köppen himself and other climatologists. As with the Iberian Peninsula and Balearic Islands Atlas, this atlas has also followed the framework proposed by Köppen in his latest version of 1936, also known as the Köppen-Geiger Classification. The only exception is that the temperature limit which separates temperate climates $\mathrm{C}$ and $\mathrm{D}$, was chosen as $0{ }^{\circ} \mathrm{C}$, as proposed by Russel, Trewartha, Critchfield and other authors (ESSENWANGER, 2001), instead of $-3.0^{\circ} \mathrm{C}$ used in the original classification. This framework is the same as that used in the internationally updated classification, published recently by PEEL AT AL. (2007). 
La delimitación de las zonas climáticas se ha realizado aplicando técnicas de álgebra de mapas a las capas de temperatura y precipitación medias mensuales que se habían creado previamente para los mapas de temperatura y precipitación del presente Atlas climático.

El resultado de la clasificación muestra los siguientes tipos de clima presentes en Canarias, Madeira y Azores:

\section{a) Climas Secos - Tipo B}

La delimitación de los climas áridos (tipo B) se realiza definiendo tres umbrales diferentes según el régimen anual de precipitaciones para tener en cuenta que la precipitación invernal es más efectiva para el desarrollo de la vegetación que la estival al ser menor la evaporación:

$\square \mathrm{P}=20(\mathrm{~T}+7)$ : precipitación repartida a lo largo del año;

$\square$ P = 20 T: verano seco (el 70\% o más de la precipitación anual se concentra en el semestre comprendido entre octubre y marzo);

口 $\mathrm{P}=20$ ( $\mathrm{T}+14)$ : invierno seco (el 70\% o más de la precipitación anual se concentra en el semestre comprendido entre abril y septiembre);

donde P es la precipitación total anual en mm y T es la temperatura media anual en ${ }^{\circ} \mathrm{C}$. En Canarias, Madeira y Azores únicamente se dan los dos primeros casos.

Köppen distingue entre dos subtipos de clima, BS (estepa) y BW (desierto) según la precipitación anual alcance o no la mitad del valor umbral establecido anteriormente para delimitar los clima de tipo B.

A su vez distingue entre las variedades cálida (letra h) y fría (letra k) según la temperatura media anual esté por encima o por debajo de $18{ }^{\circ} \mathrm{C}$ respectivamente.

\section{BWh (desierto cálido) y BWk (desierto frío)}

La variedad BWh es el clima predominante en las islas de Lanzarote y Fuerteventura, extendiéndose por prácticamente toda la superficie de las islas salvo las zonas más altas. También se distribuye ampliamente por el sur de las islas de Gran Canaria, Tenerife y La Gomera y, en menor medida, en zonas costeras de la isla de El Hierro. La variedad BWk se observa únicamente de forma testimonial en las laderas del suroeste de las islas de Tenerife y La Gomera, entre 500 y 700 m de altitud.

\section{BSh (estepa cálida) y BSk (estepa fría)}

Se observan en todas las islas del archipiélago canario, frecuentemente reemplazando a los climas desérticos al aumentar la altitud. En Fuerteventura y Lanzarote se circunscriben a las cumbres más altas de las islas, mientras que en Gran Canaria se extienden ampliamente por una franja de altitud media-baja en el norte de la isla y a mayor altitud en la vertiente sur. Alcanzan el nivel del mar en el norte y este de las islas de Tenerife, La Gomera y el Hierro, mientras que en La Palma son las variedades de clima predominantes en las zonas más secas situadas en las costas del suroeste.

En el archipiélago de Madeira, el tipo de clima BSh se observa en casi toda la isla de Porto Santo.

\section{b) Climas Templados - Tipo C}

La temperatura media del mes más frío está comprendida entre 0 y $18^{\circ} \mathrm{C}$. Köppen distingue entre los
A delimitação das zonas climáticas realizou-se aplicando técnicas de álgebra de mapas às "grelhas" das médias mensais de temperatura do ar e da precipitação, que foram previamente calculadas para os mapas de temperatura e precipitação do presente Atlas.

$O$ resultado da classificação mostra os seguintes tipos de clima presentes nos arquipélagos dos Açores, da Madeira e das Canárias:

\section{a) Climas Secos - Tipo B}

A delimitação dos climas áridos (tipo B) realiza-se definindo 3 intervalos diferentes conforme o regime anual de precipitação, de forma a ter em conta que a precipitação do Inverno é mais efetiva para o desenvolvimento da vegetação do que a época estival, ao ser menor a evaporação:

$\square \mathrm{P}=20(\mathrm{~T}+7):$ precipitação repartida ao longo do ano;

口 $\mathrm{P}=20$ T: Verão seco $(70 \%$ ou mais da precipitação anual concentra-se no semestre Outono-Inverno);

$\square \mathrm{P}=20(\mathrm{~T}+14)$ : Inverno seco $(70 \%$ ou mais da precipitação anual concentra-se no semestre Primavera-Verão);

onde $\mathrm{P}$ é a precipitação total anual em mm e T é a temperatura média anual em ${ }^{\circ} \mathrm{C}$. Nas Canárias, Madeira e Açores unicamente se observam os dois primeiros casos.

Köppen distingue entre dois subtipos de clima, BS (estepe) e BW (deserto) conforme a precipitação anual atinge ou não respetivamente metade do valor limite estabelecido anteriormente para delimitar os climas de tipo $\mathrm{B}$.

Distingue ainda entre as variedades quente (letra h) e fria (letra k) de acordo com a temperatura média anual, se esta está acima ou abaixo dos $18^{\circ} \mathrm{C}$ respetivamente.

\section{$B W h$ (deserto quente) y $B W k$ (deserto frio)}

A variedade $\mathrm{BWh}$ é o clima predominante nas ilhas de Lanzarote e Fuerteventura, estendendo-se praticamente por toda a superfície das ilhas, com exceção das zonas mais altas. Também se distribui amplamente pelo sul das ilhas da Gran Canária, Tenerife e La Gomera e em menor extensão nas áreas de baixa altitude da ilha de El Hierro. A variedade BWk observa-se unicamente em pequenas zonas do sudoeste das ilhas de Tenerife e La Gomera, numa estreita faixa de altitudes entre 500 e $700 \mathrm{~m}$.

\section{BSh (estepe quente) y BSk (estepe fria)}

Ambas as variedades observam-se em todas as ilhas do arquipélago das Canarias com o aumento da altitude. Em Fuerteventura e Lanzarote apenas ocorre nas áreas mais altas das ilhas, mas na Gran Canária estende-se amplamente por uma faixa de altitude media-baixa no norte da ilha e em maiores altitudes na vertente sul. Também se verifica ao nível médio do mar no norte e este das ilhas de Tenerife, La Gomera e El Hierro, mas em La Palma são as variedades de clima predominantes nas zonas mais secas situadas na costa sudoeste.

No arquipélago da Madeira, o tipo de clima BSh observa-se em quase toda a ilha de Porto Santo.

\section{b) Climas Temperados - Tipo C}

A temperatura média do mês mais frio está compreendida entre 0 e $18{ }^{\circ} \mathrm{C}$. Köppen distingue entre os
The delineation of climatic zones was carried out by applying map algebra techniques to the "grids" of the monthly average air temperature and precipitation, which were previously calculated for the temperature and precipitation maps of this Atlas.

The result of the classification shows the following types of climate found in the archipelagos of the Azores, Madeira and the Canary Islands:

\section{a) Dry Climates - Type B}

The delineation of arid climates (type B) is carried out by defining three different intervals according to the annual precipitation regime, taking into account that the winter precipitation is more effective for the development of vegetation than the summer season, having less evaporation:

$\square \mathrm{P}=20(\mathrm{~T}+7)$ : precipitation spread throughout the year;

$\square \mathrm{P}=20 \mathrm{~T}$ : dry summer $(70 \%$ or more of the annual precipitation is accounted for the Autumn/Winter six month period);

$\square \mathrm{P}=20(\mathrm{~T}+14)$ : dry winter $(70 \%$ or more of the annual precipitation is accounted for the Spring/ Summer six month period);

where $\mathrm{P}$ is the total annual precipitation in $\mathrm{mm}$ and $\mathrm{T}$ is the average annual temperature in ${ }^{\circ} \mathrm{C}$. In the Canary Islands, Madeira and the Azores only the first two cases were observed.

Köppen distinguishes between two subtypes of climate, BS (steppe) and BW (desert) as the annual precipitation reaches, or does not reach, respectively, half of the previously established threshold value in order to determine the climates of type B.

Moreover he distinguishes between the varieties hot (letter h) and cold (letter k) in accordance with the annual average temperature, if same is above or below $18^{\circ} \mathrm{C}$ respectively.

\section{$B W h($ hot desert) and BWk (cold desert)}

The BWh variety is the predominant climate on the islands of Lanzarote and Fuerteventura, stretching almost the entire surface of the islands, except for the higher areas. It is also widely distributed in the south of the islands of Gran Canaria, Tenerife and La Gomera, and to a lesser extent in low-lying areas of the island of El Hierro. The BWK variety is observed only in small areas in the southwest of the islands of Tenerife and La Gomera, in a narrow altitude range between 500 and $700 \mathrm{~m}$.

\section{BSh (hot steppe) y BSk (cold steppe)}

Both varieties are observed in all of the islands of the Canaries, increasing with altitude. In Fuerteventura and Lanzarote it only occurs in the highest areas of the islands, but in Gran Canaria it varies widely over a range of medium-low altitudes in the north of the island and at higher altitudes on the southern slope. Furthermore it is observed at the average sea level in the north and east of the islands of Tenerife, La Gomera and El Hierro. However in La Palma the varieties of climate are those prevailing in the drier areas located on the southwest coast.

On the archipelago of Madeira, the BSh climate is observed in almost the entire island of Porto Santo.

\section{b) Temperate Climates - Type C}

The average temperature of the coldest month is between 0 and $18^{\circ} \mathrm{C}$. Köppen distinguishes between 
subtipos Cs, Cw y Cf según se observe un periodo marcadamente seco en verano (Cs), en invierno (Cw) o bien no haya una estación seca (Cf). El subtipo Cw no aparece en Canarias, Madeira y Azores.

A su vez añade una tercera letra según sea el verano caluroso (temperatura media del mes más cálido superior a $22{ }^{\circ} \mathrm{C}$, letra a), templado (temperatura media del mes más cálido menor o igual a $22^{\circ} \mathrm{C}$ y cuatro o más meses con temperatura media superior a $10{ }^{\circ} \mathrm{C}$, letra b) o fresco (temperatura media del mes más cálido menor o igual a $22^{\circ} \mathrm{C}$ y menos de cuatro meses con temperatura media superior a $10^{\circ} \mathrm{C}$, letra c).

\section{Csa (templado con verano seco y cálido)}

Esta variedad se observa principalmente en zonas costeras del norte y este de la isla de La Palma y a mayor altitud en las islas de Gran Canaria, Tenerife y La Gomera.

En el archipiélago de Madeira esta variedad se observa en las zonas costeras de la isla de Madeira y en algunos lugares puntuales de mayor altitud de la isla de Porto Santo.

En el archipiélago de las Azores el clima Csa se observa en las zonas costeras de las islas de Faial y de Graciosa, en la región oeste de la isla de Pico, en las costas sur y este de la isla Terceira, en parte de la costa sur de la isla de San Miguel y en la región occidental de la isla de Santa María.

\section{Csb (templado con verano seco y templado)}

Se extiende ampliamente por el interior de las islas de La Palma, El Hierro, La Gomera y Tenerife, así como en las zonas más elevadas de Gran Canaria.

En el archipiélago de Madeira esta variedad es la predominante en la isla de Madeira y en la isla de Porto Santo solo se encuentra en las áreas de mayor altitud.

En el archipiélago de las Azores el clima del tipo Csb se observa principalmente en las islas del grupo Central y Oriental, en concreto en la región oeste de la isla de Faial, en una pequeña franja del noroeste de la isla de Pico, en algunas zonas de la isla de Graciosa, en la punta sureste de la isla de San Jorge, en gran parte de la franja costera de las islas de Terceira y de San Miguel y en la mayor parte de la isla de Santa María.

\section{Csc (templado con verano seco y fresco)}

En las islas Canarias se observa únicamente en una estrecha franja alrededor del Pico del Teide en la isla de Tenerife, entre 2600 y $2900 \mathrm{~m}$ de altitud aproximadamente.

En el archipiélago de Madeira la clasificación de tipo Csc se observa en las pequeñas áreas de altitud del Pico Ruivo y del Pico do Areeiro. En las Azores no se observa esta variedad de clima.

Cfa (templado sin estación seca con verano caluroso)

No se observa en las islas Canarias ni en Madeira. En las Azores se observa en las áreas costeras del sur, nordeste y este de la isla de Pico y en pequeñas áreas del litoral de las islas de Corvo, de Flores y de San Jorge.

Cfb (templado sin estación seca con verano templado)

No se observa en las islas Canarias ni en Madeira En el Archipiélago de las Azores este tipo de clima subtipos $\mathrm{Cs}$, $\mathrm{Cw}$ e $\mathrm{Cf}$, conforme se observa um período marcadamente seco no Verão $(\mathrm{Cs})$, no Inverno $(\mathrm{Cw})$, ou se não há uma estação seca $(\mathrm{Cf})$. $\mathrm{O}$ subtipo $\mathrm{Cw}$ não se observa nas ilhas dos Açores, Madeira e Canárias.

Existe ainda uma terceira letra conforme o Verão é quente (temperatura média do mês mais quente superior a $22^{\circ} \mathrm{C}$, letra a), é temperado (temperatura média do mês mais quente menor ou igual a $22{ }^{\circ} \mathrm{C}$ e com quatro meses, ou mais, com temperatura média superior a $10{ }^{\circ} \mathrm{C}$, letra b), ou é frio (temperatura média do mês mais quente menor ou igual a $22^{\circ} \mathrm{C}$ e com menos de quatro meses com temperatura média superior a $10{ }^{\circ} \mathrm{C}$, letra c).

\section{Csa (temperado com Verão seco e quente)}

Esta variedade observa-se principalmente nas zonas costeiras do norte e este da ilha de La Palma e nas altitudes mais elevadas das ilhas da Gran Canária, Tenerife e La Gomera.

No arquipélago da Madeira, esta variedade observa-se nas zonas costeiras da ilha da Madeira e nalguns locais pontuais de maior altitude da ilha de Porto Santo.

No arquipélago dos Açores o clima Csa observase nas zonas costeiras das ilhas do Faial e da Graciosa, na região oeste da ilha do Pico, nas costas sul e este da ilha Terceira, parte da costa sul da ilha de São Miguel e na região oeste da ilha de Santa Maria.

\section{Csb (temperado com Verão seco e temperado)}

Estende-se amplamente pelo interior das ilhas de La Palma, El Hierro, La Gomera y Tenerife, assim como nas zonas mais elevadas da Gran Canária.

No arquipélago da Madeira, esta variedade é a predominante na ilha da Madeira e na ilha de Porto Santo ocorre apenas nas áreas de maior altitude.

No arquipélago dos Açores o clima do tipo Csb observa-se essencialmente nas ilhas do grupo Central e Oriental, em particular na região oeste da ilha do Faial, numa pequena faixa do noroeste da ilha do Pico, nalgumas zonas da ilha da Graciosa, na ponta sueste da ilha de São Jorge, em grande parte da faixa litoral das ilhas da Terceira e de São Miguel e na maior parte da ilha de Santa Maria.

\section{Csc (temperado com Verão seco e fresco)}

A variedade Csc nas ilhas Canárias observa-se unicamente numa estreita faixa em redor do pico de Teide, entre 2600 e $2900 \mathrm{~m}$ de altitude aproximadamente.

No arquipélago da Madeira a classificação do tipo Csc observa-se nas pequenas áreas de altitude do Pico Ruivo e do Pico do Areeiro. Nos Açores não se observa esta variedade de clima.

\section{Cfa (temperado sem estacão seca com Verão} quente)

Não se observa nas ilhas Canárias nem na Madeira. Nos Açores observa-se nas áreas costeiras sul, nordeste e este da ilha do Pico e em pequenas áreas do litoral das ilhas do Corvo, das Flores e de São Jorge.

\section{Cfb (temperado sem estacão seca com Verão temperado)}

Não se observa nas ilhas Canárias nem na Madeira. No Arquipélago dos Açores este tipo de clima é o subtypes $\mathrm{Cs}, \mathrm{Cw}$ and $\mathrm{Cf}$, as observed in a markedly dry summer $(\mathrm{Cs})$ period, in winter $(\mathrm{Cw})$, or if there is a dry season (Cf). The subtype $\mathrm{Cw}$ is not observed in the Azores, Madeira and the Canaries.

Further still, there is a third letter when the summer is hot (average temperature of the warmest month above $22{ }^{\circ} \mathrm{C}$, letter a), is temperate (average temperature of the warmest month less than or equal to $22{ }^{\circ} \mathrm{C}$ and with four months or more with an average temperature of more than $10^{\circ} \mathrm{C}$, letter b), or is cold (average temperature of the warmest month less than or equal to $22{ }^{\circ} \mathrm{C}$ and less than four months with an average temperature above $10{ }^{\circ} \mathrm{C}$, letter c).

\section{Csa (temperate with hot and dry summer)}

This variety is observed in coastal areas of the north and east of the island of La Palma and in the higher elevations of the islands of Gran Canaria, Tenerife and La Gomera.

On the archipelago of Madeira, this variety is observed in the coastal zones of Madeira and in some places with the highest altitude on the island of Porto Santo.

On the archipelago of the Azores the Csa climate is observed in coastal areas of the island of Faial and Graciosa, in the west of the island of Pico, in the south and east coasts of the island of Terceira, part of the southern coast of São Miguel and west of the island of Santa Maria.

\section{Csb (temperate with dry and warm summers)}

It extends widely through the interior of the islands of La Palma, El Hierro, La Gomera and Tenerife, as well as in higher areas of Gran Canaria.

In the archipelago of Madeira, this variety is predominant on the island of Madeira, and on the island of Porto Santo it only occurs in areas of higher altitude.

In the archipelago of the Azores the Csb climate variant is observed mainly on the islands of the Central and Eastern group, particularly in the western part of the island of Faial, on a small strip on the north-west of the island of Pico, in some areas of the island of Graciosa, the south-eastern tip of the island of São Jorge, a large part of the coastline of the islands of Terceira and São Miguel and most of the island of Santa Maria.

\section{Csc (temperate with dry and cool summers)}

The Csc variety in the Canary Islands is only observed in a narrow band around the Pico de Teide, between altitudes of approximately 2600 and $2900 \mathrm{~m}$

In the archipelago of Madeira the classification of the Csc variant is observed in small areas of altitude of Pico Ruivo and of Pico do Areeiro. This variety of climate is not observed in the Azores.

Cfa (temperate with no dry season and with hot summer)

It is not observed in the Canary Islands or in $\mathrm{Ma}$ deira. In the Azores it is observed in the southern, northern and eastern coastal areas of Pico Island and in small coastal areas of the islands of Corvo, Flores and São Jorge.

\section{Cfb (temperate with no dry season with a mild} summer)

Not observed in the Canary Islands or Madeira. In the Azores this type of climate is prevalent in 
es el predominante en casi todas las islas, solo en las islas de Santa María y de Graciosa no se observa esta variedad en la mayor parte del territorio.

Cfc (templado sin estación seca con verano corto $y$ fresco)

Este tipo de clima apenas se observa en el archipiélago de las Azores, en una estrecha franja alrededor de la montaña de Pico, en la isla homónima.

\section{c) Climas Fríos - Tipo D}

La temperatura media del mes más frío es inferior a $0{ }^{\circ} \mathrm{C}$ y la temperatura media del mes más calido es superior a $10^{\circ} \mathrm{C}$. Los umbrales para los subtipos y variedades del clima D son análogos a los del clima $\mathrm{C}$, con el añadido de una cuarta variante para la tercera letra correspondiente a climas con inviernos muy fríos (temperatura del mes más frío inferior a $-38{ }^{\circ} \mathrm{C}$, letra d) que no se observa en Canarias, Madeira y Azores.

\section{Dfc (frío sin estación seca y verano fresco)}

Se localiza únicamente en las zonas más altas de la isla de Tenerife, desde unos $2900 \mathrm{~m}$ de altitud hasta la cima del Teide.

\section{d) Climas Polares - Tipo E}

La temperatura media del mes más cálido es inferior a $10^{\circ} \mathrm{C}$. Köppen define dos subtipos: ET (tundra, la temperatura media del mes más cálido es superior a $0{ }^{\circ} \mathrm{C}$ ) y EF (glacial, la temperatura media del mes más cálido es inferior a $0{ }^{\circ} \mathrm{C}$ ). El subtipo EF no se da en Canarias, Madeira y Azores.

\section{ET (tundra)}

Se observa únicamente en las Azores, en la montaña del Pico (isla de Pico) a partir de los 1600 metros de altitude. predominante em quase todas as ilhas, apenas nas ilhas de Santa Maria e da Graciosa não se observa esta variedade na maior parte do território.

Cfc (temperado sem estacão seca com Verão curto e fresco)

Este tipo de clima apenas se observa no arquipélago dos Açores, numa estreita faixa em redor da montanha do Pico na ilha do Pico.

\section{c) Climas Frios - Tipo D}

A temperatura média do mês mais frio é inferior a $0{ }^{\circ} \mathrm{C}$ e a temperatura média do mês mais quente é superior a $10{ }^{\circ} \mathrm{C}$. Os intervalos considerados para os subtipos e variedades do clima D são análogos aos do clima $\mathrm{C}$, com a adição de uma quarta variante para a terceira letra correspondente a climas com invernos muito frios (temperatura do mês mais frio inferior a $-38{ }^{\circ} \mathrm{C}$, letra d) que não se observa nas Canárias, na Madeira e nos Açores.

\section{Dfc (frio sem estacão seca e Verão fresco)}

Observa-se unicamente nas zonas mais altas de ilha de Tenerife, desde os $2900 \mathrm{~m}$ de altitude até ao cimo do Pico de Teide.

\section{d) Climas Polares - Tipo E}

A temperatura média do mês mais quente é inferior a $10{ }^{\circ} \mathrm{C}$. Köppen define dois subtipos: ET (tundra: a temperatura média do mês mais quente é superior a $0{ }^{\circ} \mathrm{C}$ ) e EF (glacial: a temperatura media do mês mais quente é inferior a $\left({ }^{\circ} \mathrm{C}\right.$ ). $\mathrm{O}$ subtipo $\mathrm{EF}$ não se observa nas Canárias, nem na Madeira, nem nos Açores.

\section{ET (tundra)}

Observa-se unicamente no Açores, na montanha do Pico (ilha do Pico) a partir de cerca de 1600 metros de altitude. nearly all the islands. It is only on the islands of Santa Maria and Graciosa that this variety is not seen in most of the territory.

Cfc (temperate with no dry season with a short and cool summer)

This type of climate is observed only in the archipelago of the Azores, in a narrow band around Mount Pico on the island of Pico.

\section{c) Cold Climates - Type D}

The average temperature of the coldest month is less than $0{ }^{\circ} \mathrm{C}$ and the average temperature of the warmest month is over $10^{\circ} \mathrm{C}$. The ranges considered for subtypes and climate varieties $\mathrm{D}$ are similar to that of climate type $\mathrm{C}$, with the addition of a fourth option for the third letter for climates with very cold winters (temperature of the coldest month below $-38^{\circ} \mathrm{C}$, letter d) that is not observed in the Canary Islands and Madeira or in the Azores.

Dfc (cold without a dry season and a fresh summer)

It is observed only in the highest areas of the island of Tenerife, from an altitude of $2900 \mathrm{~m}$ to the top of Pico de Teide.

\section{d) Polar Climates - Type E}

The average temperature of the warmest month is less than $10^{\circ} \mathrm{C}$. Köppen defines two subtypes: ET (tundra: the average temperature of the warmest month is above $0^{\circ} \mathrm{C}$ ) and $\mathrm{EF}$ (glacial: the average temperature of the warmest month is less than $0^{\circ} \mathrm{C}$ ). The subtype EF is not observed in the Canary Islands and Madeira or in the Azores.

\section{ET (tundra)}

It is only observed in the Azores, in Mount Pico (Island of Pico) from an altitude of around 1600 metres. 


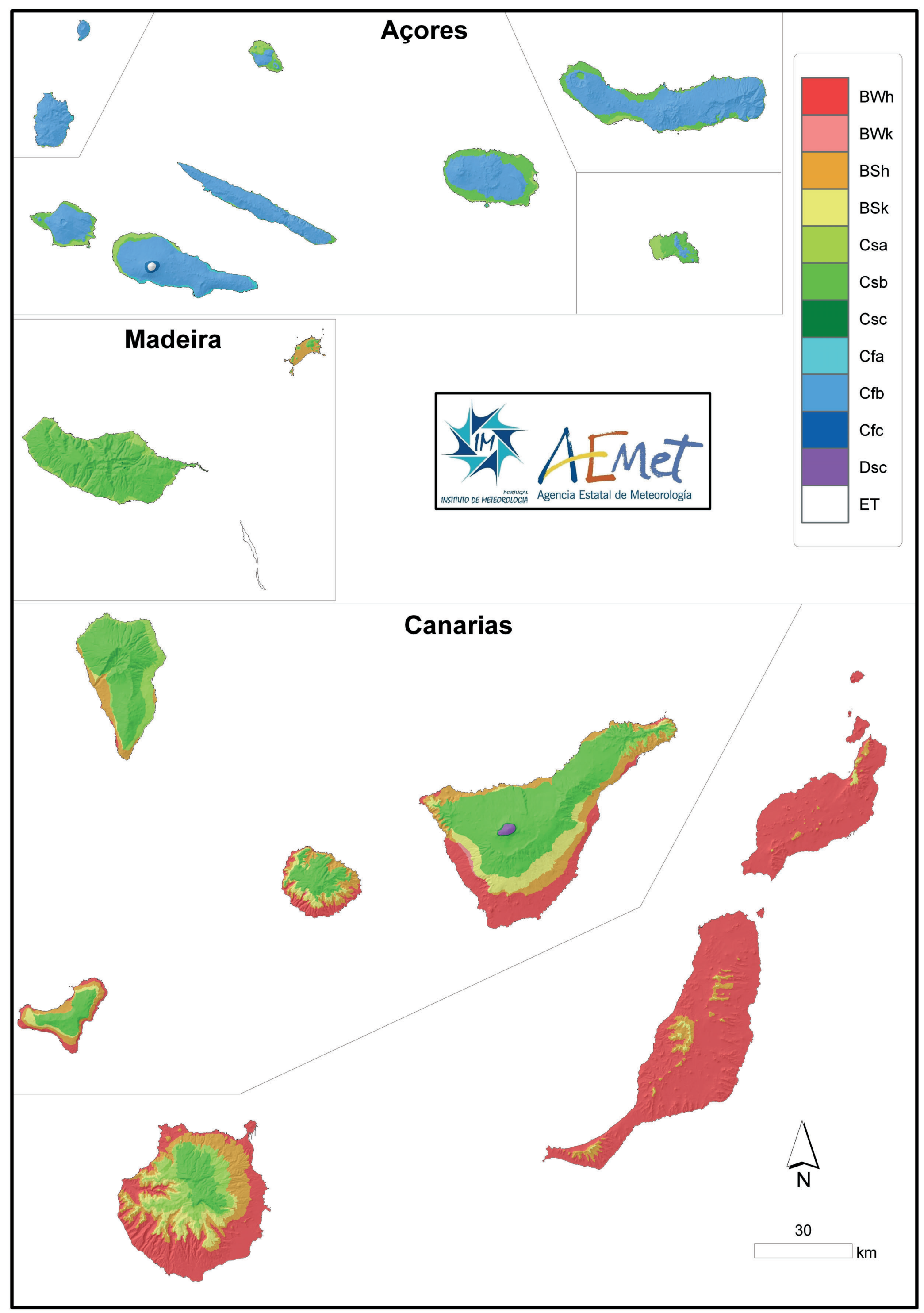

Fig. 3. Clasificación climática de Köppen-Geiger en los archipiélagos de Azores, Madeira y Canarias.

Classificaç̃o climática de Köppen-Geiger nos arquipélagos dos Açores, da Madeira e das Canárias.

Köppen-Geiger climate classification in the archipelagos of the Azores, Madeira and the Canary Islands. 



\section{Observaciones meteorológicas}

Las observaciones meteorológicas han sido y son utilizadas para registrar las condiciones meteorológicas de cada lugar y su evolución, a fin de caracterizar los respectivos climas. Con vistas a la comparación de resultados entre diferentes regiones ha sido necesario definir criterios y procedimientos para las redes de estaciones según normas internacionales, relacionadas con la resolución espacio-temporal de los fenómenos meteorológicos.

\subsection{Observaciones en Canarias}

Las singulares características del archipiélago canario, su ubicación geográfica, su compleja orografía y la especificidad de su fauna, flora y clima ha atraído desde hace siglos un notable interés científico, que hizo que Alexander Von Humbold visitara Tenerife en 1799 y escalara el Teide tomando medidas de temperatura del aire y presión. En la primera mitad del siglo XIX ya hay reseñas del clima canario y se confeccionan los primeros planes para establecer un observatorio en Tenerife.

Los primeros datos meteorológicos oficiales en Canarias datan de enero de 1865 cuando se inician las

\section{Observações meteorológicas}

As observações meteorológicas foram e são utilizadas para registar as condições meteorológicas de cada local e a sua evolução, a fim de caracterizar os respectivos climas. Com vista à comparação de resultados, entre diferentes regiões, tornou-se necessário definir critérios e procedimentos para as redes de estações segundo normas internacionais, relacionadas com a resolução espácio-temporal dos fenómenos meteorológicos.

\subsection{Observações nas Canárias}

As características singulares do arquipélago das Canárias, a sua localização geográfica, a sua orografia complexa e a especificidade da sua fauna, flora e clima, atraíram desde há vários séculos um notável interesse científico, que trouxe Alexander Von Humbold a visitar Tenerife em 1799 e a escalar o Teide, fazendo medições de temperatura do ar da pressão. Na primeira metade do século XIX já havia resumos do clima das Canárias e preparavam-se os primeiros planos para estabelecer um observatório em Tenerife.

Os primeiros dados meteorológicos oficiais nas Canárias datam de janeiro de 1865 , data em que se

\section{Meteorological observations}

Meteorological observations were used, and continue to be used, to record meteorological conditions in each location, as well as any climatic changes, in order to classify the respective climates. In order to compare results between different regions, criteria and processes were defined across the networks of weather stations, in accordance with international standards, related to the time-space resolution of meteorological phenomena.

\subsection{Observations in the Canary Islands}

The unique features of the Canary Islands, their geographical location, their complex orography and specificity of its flora, fauna and climate, have attracted a notable scientific interest over several centuries that brought Alexander Von Humboldt to visit Tenerife in 1799 , climbing Mount Teide, taking pressure and air temperature measurements. In the first half of the nineteenth century outlines of the climate of the Canary Islands, had already been established and the first plans to establish an observatory in Tenerife had been laid.

The first official meteorological data in the Canary Islands date back to January 1865, data which

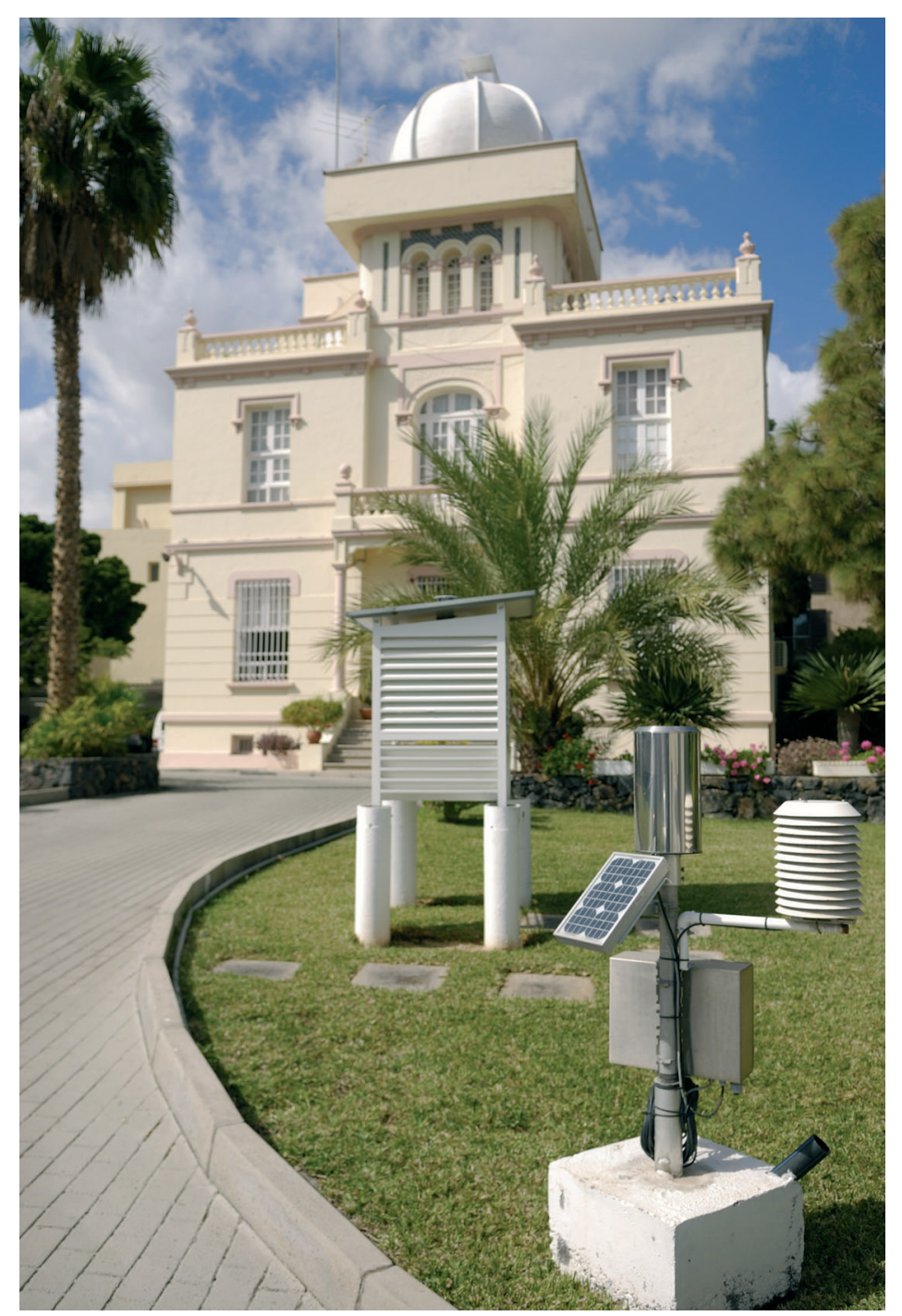

Centro meteorológico de Santa Cruz de Tenerife.

Centro meteorológico de Santa Cruz de Tenerife.

Meteorological centre of Santa Cruz de Tenerife. 


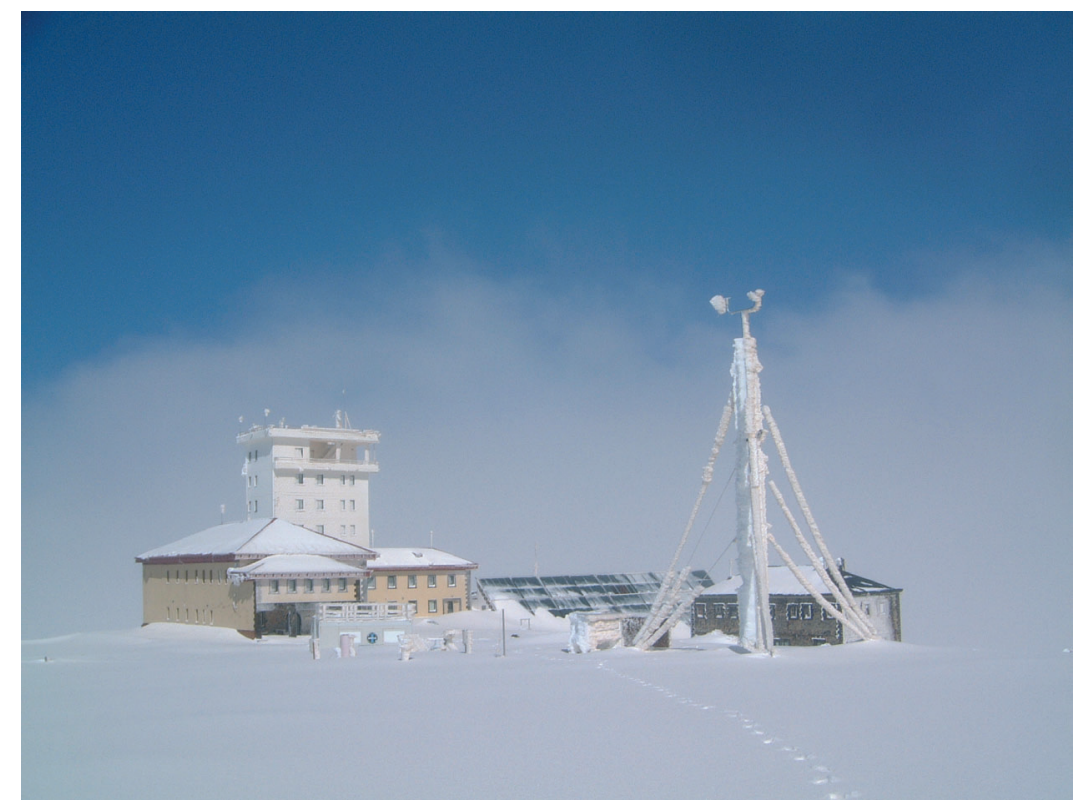

Observatorio meteorológico de Izaña. Observatório meteorológico de Izanha. Meteorological observatory of Izaña.

observaciones en el observatorio de Santa Cruz de Tenerife, que entonces se ubicaba en el Ayuntamiento. En 1869 se inician también las observaciones en el observatorio de La Laguna y en 1881 en el de Las Palmas de Gran Canaria. A lo largo de la primera mitad del siglo XX la red de estaciones meteorológicas se fue incrementando lentamente y ya a partir de 1945 el número de estaciones aumenta rápidamente disponiéndose en torno a 1950 de un total de 100 estaciones pluviométricas y 20 estaciones termométricas. A finales de la década de 1980 el número de estaciones pluviométricas llegó a 600 mientras que el de termométricas superaba las 130, disminuyendo ambos valores de forma gradual a partir de ese momento. A partir de 1985, en el contexto de la modernización del entonces Instituto Nacional de Meteorología, se inicia el proceso de automatización de la red de superficie con la adquisición e instalación de estaciones meteorológicas automáticas y más recientemente se ha abordado también la automatización progresiva de la red climatológica secundaria con la implantación de nuevas estaciones automáticas, de forma que actualmente la red de observación meteorológica de AEMET en el archipiélago, gestionada por la Delegación Territorial de AEMET en Canarias, cuenta con 11 estaciones principales, 61 estaciones meteorológicas automáticas, 48 estaciones termométricas y 215 estaciones pluviométricas.

Por su carácter singular merece la pena referirse con cierto detalle al observatorio de Izaña, situado a $2367 \mathrm{~m}$ de altitud en el macizo del Teide. Este observatorio se inaugura el primer día del año 1916, si bien ya en los primeros años del siglo XX existía un gran interés internacional en establecer un observatorio permanente en el pico del Teide que se enmarcaba en el establecimiento de una red aerológica en el hemisferio norte y en el año 1909 científicos alemanes ya habían establecido una estación meteorológica permanente en las Cañadas del Teide, en un emplazamiento cercano al que ocupa actualmente el observatorio de Izaña. A partir de 1916 el observatorio de Izaña desarrolla su actividad de observación meteorológica al tiempo que por su localización privilegiada para las investigaciones atmosféricas acoge numerosos experimentos e investigaciones atmosféricas por la comunidad científica internacional. En 1984, por acuerdo de los Gobiernos de España y Alemania, el Observatorio se incorporó a la Red de Vigilancia de la Contaminación de Fondo (Red BAPMoN de la OMM). En 1990 la red BAPMoN y el Sistema Mundial de Observación del Ozono se funden en el nuevo programa de la Vigilancia Atmosférica Global (VAG), programa en el iniciam as observações no observatório de Santa Cruz de Tenerife, que estava instalado no "Ayuntamiento". Em 1869 iniciam-se também as observações no observatório de La Laguna e em 1881 no observatório de Las Palmas de Gran Canária. Ao longo da primeira metade do siglo XX a rede de estações meteorológicas foi crescendo progressivamente e a partir de 1945 o número de estações aumenta rapidamente dispondose em cerca de 1950 de um total de 100 estações udométricas e de 20 estações termométricas. Em finais da década de 1980 o número de estações udométricas chegou a 600, enquanto as termométricas ultrapassava as 130 , diminuindo ambos os números de forma gradual desde essa altura. A partir de 1985, no contexto da modernização do ex-Instituto Nacional de Meteorologia, inicia-se o processo de automatização da rede de superfície com a aquisição e instalação de Estações Meteorológicas Automáticas e, mais recentemente, foi também abordada a automatização progressiva da rede climatológica secundária, com a implantação de novas Estações Automáticas, de forma que atualmente a rede de observação meteorológica da AEMET no arquipélago, gerida pela Delegação da AEMET nas Canárias, conta com 11 estações principais, 61 Estações Meteorológicas Automáticas, 48 estações termométricas e 215 estações udométricas.

Pelo seu carácter singular, merece a pena referir-se com certo detalhe o observatório de Izaña, localizado a $2367 \mathrm{~m}$ de altitude no maciço do Teide. Este observatório foi inaugurado no primeiro dia do ano 1916, uma vez que nos primeiros anos do século XX existia um grande interesse internacional em estabelecer um observatório permanente no pico do Teide, que se enquadrava no estabelecimento de uma rede aerológica no Hemisfério Norte e, no ano de 1909 cientistas alemães tinham já estabelecido uma estação meteorológica permanente nas "Cañadas del Teide", num local próximo do que ocupa atualmente o observatório de Izaña. A partir de 1916 o Observatório de Izaña desenvolve a sua atividade de observação meteorológica e em simultâneo, devido à sua localização privilegiada para a investigação atmosférica, acolhe numerosas experiências e projetos atmosféricos da comunidade científica internacional. Em 1984, por acordo dos Governos de Espanha e da Alemanha, o observatório passou a integrar a Rede de Vigilância de da Poluição de Fundo (Rede BAPMoN da OMM). Em 1990 a rede BAPMoN e o Sistema Mundial de Observação do Ozono fundem-se num novo programa de Vigilância Atmosférica Global (VAG), programa no qual a estação de Izaña initiated the observations at the observatory of Santa Cruz de Tenerife, which was installed in the "Town Hall". In 1869 observations also begin at the observatory in La Laguna, and in 1881 at the observatory in Las Palmas de Gran Canaria. During the first half of the twentieth century a network of meteorological stations progressively grew and in 1945 the number of stations increased rapidly using, in around 1950, a total of 100 udometer stations and 20 thermometric stations. In the late 1980s the number of udometer stations reached 600 , while the thermometric stations surpassed 130, with both numbers decreasing gradually since then. From 1985, in the context of the modernization of the former National Institute of Meteorology, the process of automating surface network began with the acquisition and installation of Automatic Weather Stations and more recently, the progressive automation of the secondary climatological network was addressed, with the implementation of new automatic stations Therefore now the network of meteorological observation of the Spanish Meteorological Service (AEMET) in the archipelago, managed by the Delegation of the Spanish Meteorological Service (AEMET) in the Canary Islands, has 11 main stations, 61 automatic meteorological stations, 48 thermometric stations and 215 udometer stations.

Due to its unique character, it is worth referring in some detail to the Izaña observatory, located at an altitude of $2367 \mathrm{~m}$ on the massif of Mount Teide. This observatory was opened on the first day of the year in 1916. Since the early years of the twentieth century there was a great international interest in establishing a permanent observatory on the peak of Mount Teide. This encapsulated the establishment of an aerological network in the Northern Hemisphere and in 1909 German scientists had already established a permanent meteorological station in the "Cañadas del Teide", a location close to what is currently the Izaña observatory. From 1916 the Izaña observatory undertook its activity of meteorological observation and, simultaneously, due to its prime location for atmospheric research, it hosted numerous experiments and atmospheric projects of the international scientific community. In 1984, by means of an agreement between the Governments of Spain and Germany, the Centre integrated the Background Station Surveillance Network (BAPMoN Network of the WMO). In 1990 the BAPMoN network and the Global Ozone Observing System merged into a new programme for the Global Atmospheric Watch 
Estación meteorológica del Pico do Areeiro en los años 50.

Estação meteorológica do Pico do Areeiro nos anos 50

Meteorological station at Pico do Areeiro in the 1950's.

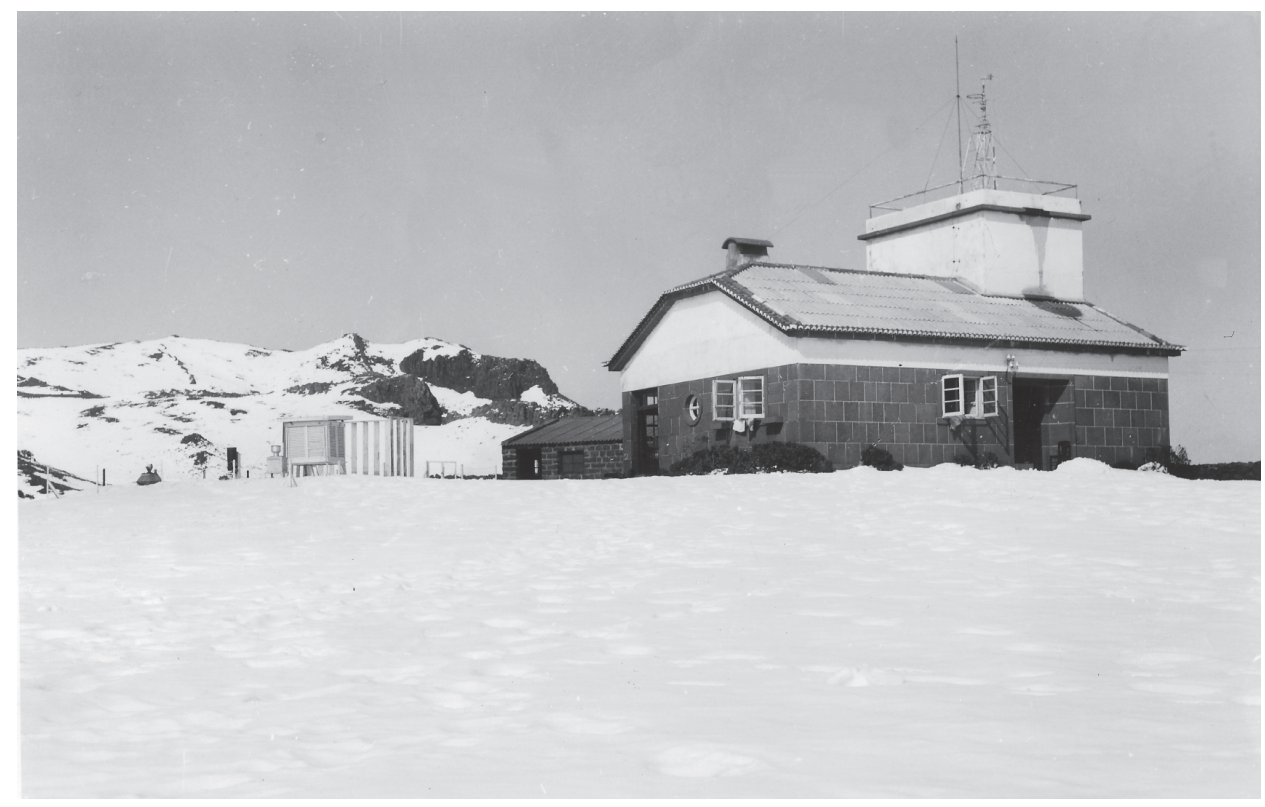

que la estación de Izaña desempeña un importante papel. En los últimos años el Centro de Investigación Atmosférica de Izaña ha participado en numerosos programas y experimentos como los de la Red de Detección de Cambios Estratosféricos (NSDC) y desarrolla actividades, con amplia colaboración internacional, en vigilancia de gases de efecto invernadero, seguimiento de la capa de ozono, investigación en aerosoles atmosféricos y calidad del aire.

\subsection{Observaciones en Madeira}

Las observaciones meteorológicas más antiguas realizadas en Portugal con continuidad, durante un intervalo razonable de tiempo y con resultados publicados o accesibles, son las del médico Tomás Heberden en Funchal, de 1747 a 1753, publicadas en Philosophical Transaction de la Sociedad Real de Londres.

Fradesso da Silveira se encargó de solicitar a las entidades locales, en abril de 1864, la instalación de estaciones meteorológicas. El 1 de diciembre de 1864 comenzaron las observaciones en la estación meteorológica, situada en el baluarte central de la fortaleza de San Lorenzo. Desde entonces se han publicado regularmente en los Anales del Observatorio y después en el Anuario del Servicio Meteorológico Nacional. El primer Director del Servicio Meteorológico de Funchal fue el Teniente-Coronel Azevedo.

Los resultados de las observaciones realizadas en Funchal solo pudieron aprovecharse en los trabajos de previsión del tiempo a partir de 1874, momento en que el cable telegráfico conectó el archipiélago de Madeira con Lisboa.

Guilherme Teles de Meneses realizó, en agosto de 1894, observaciones en Poiso (1 400 m de altitud), en Areeiro (1 $600 \mathrm{~m}$ de altitud), de junio a octubre de 1895.

En la isla de Porto Santo se realizaron observaciones meteorológicas en 1900-1902 por Adolfo C. de Noronha y los resultados están publicados en un artículo de Carlos A. De Meneses en el mismo Boletín (1927). No hay noticias de ejecución de observaciones meteorológicas regulares en las islas Desiertas ni en las Salvajes.

El Servicio Meteorológico de la Marina tuvo una estación meteorológica en Funchal, anexa a la estación radiotelegráfica instalada en el Forte do Pico. Los resultados de las observaciones se incluían en el Comunicado Colectivo Nacional. Esta estación dejó de funcionar en 1948 con la creación del Servicio desempenha um importante papel. Nos últimos anos o "Centro de Investigación Atmosférica de Izaña” participou em numerosos programas e experiências, como os da "Red de Detección de Cambios Estratosféricos" (NSDC) e desenvolve atividades com ampla colaboração internacional, na vigilância de gases com efeito de estufa, monitorização da camada de ozono, investigação em aerossóis atmosféricos e qualidade do ar.

\subsection{Observações na Madeira}

As observações meteorológicas mais antigas executadas em Portugal com continuidade, durante uma extensão razoável de tempo e com resultados publicados ou acessíveis, são as do médico Tomás Heberden no Funchal, de 1747 a 1753, publicadas em Philosophical Transaction da Sociedade Real de Londres.

Foi Fradesso da Silveira que diligenciou junto das entidades locais, em abril de 1864, a instalação de postos meteorológicos. Em 1 de dezembro de 1864 começaram as observações no posto meteorológico, situado no baluarte central da fortaleza de São Lourenço. Foram desde então regularmente publicadas nos Anais do Observatório e depois no Anuário do Serviço Meteorológico Nacional. O primeiro Diretor do Serviço Meteorológico do Funchal foi o TenenteCoronel Azevedo.

Os resultados das observaçoes executadas no Funchal só puderam ser aproveitados nos trabalhos de previsão do tempo a partir de 1874, altura em que o Cabo telegráfico fez a ligação do arquipélago da Madeira com Lisboa.

Guilherme Teles de Meneses executou, em agosto de 1894, observações no Poiso (1 400 m de altitude) -no Areeiro (1 $600 \mathrm{~m}$ de altitude) de junho a outubro de 1895

Na ilha de Porto Santo foram executadas observações meteorológicas em 1900-1902 por Adolfo C. de Noronha e os resultados encontram-se publicados num artigo de Carlos A. De Meneses no mesmo Boletim (1927). Não há notícias de execução de observações meteorológicas regulares nas ilhas Desertas nem nas Selvagens.

O Serviço Meteorológico da Marinha teve no Funchal uma estação meteorológica, anexa ao posto radiotelegráfico instalado no Forte do Pico. Os resultados das observações eram incluídos no Comunicado Coletivo Nacional. Esta estacão deixou de funcionar em 1948 com a criação do Serviço Meteorológico
(GAW) programme, in which the Izaña station now plays an important role. In recent years the "Izaña Atmospheric Research Centre" participated in numerous programmes and experiments, such as the "Network for the Detection of Stratospheric Change" (NDSC) and develops its activities with broad international collaboration in monitoring greenhouse gases, observing the ozone layer as well as carrying out research on atmospheric aerosols and air quality.

\subsection{Observations in Madeira}

The oldest continuous meteorological observations carried out in Portugal, for a reasonable period of time and with results published or otherwise accessible, are those of the physician Thomas Heberden, in Funchal, from 1747 to 1753 , published in Philosophical Transaction of the Royal Society of London.

It was Fradesso da Silveira who strove with the local authorities, in April 1864, to install meteorological posts. On December 1, 1864 the observations in the meteorological station began, situated in the central bastion of the fortress of São Lourenço. They have since been regularly published in the Annals of the Observatory and then in the National Weather Service Yearbook. The first Director of the Meteorological Service of Funchal was Lieutenant Colonel Azevedo.

The results of observations performed in Funchal could only be used in the work of weather forecasting from the year 1874, when the telegraph cable became available to connect the Islands of Madeira and Lisbon.

In August 1894 Guilherme Teles de Meneses carried out observations in Poiso (at an altitude of $1400 \mathrm{~m}$ ) — in Areeiro (at an altitude of $1600 \mathrm{~m}$ ) between June and October of 1895.

Meteorological observations were performed on the island of Porto Santo in 1900-1902 by Adolfo C. de Noronha, and the results were published in an article by Carlos A. De Meneses in the same Bulletin (1927). There is no news regarding the undertaking of regular meteorological observations on the 'Desertas' islands or in the 'Salvagens' islands.

The Naval Meteorological Service had a meteorological station in Funchal, attached to the radiotelegraph station installed at Forte Pico. The results of the observations were included in the National Press Information. This station stopped operating in 1948 with the creation of the National Meteorologi- 


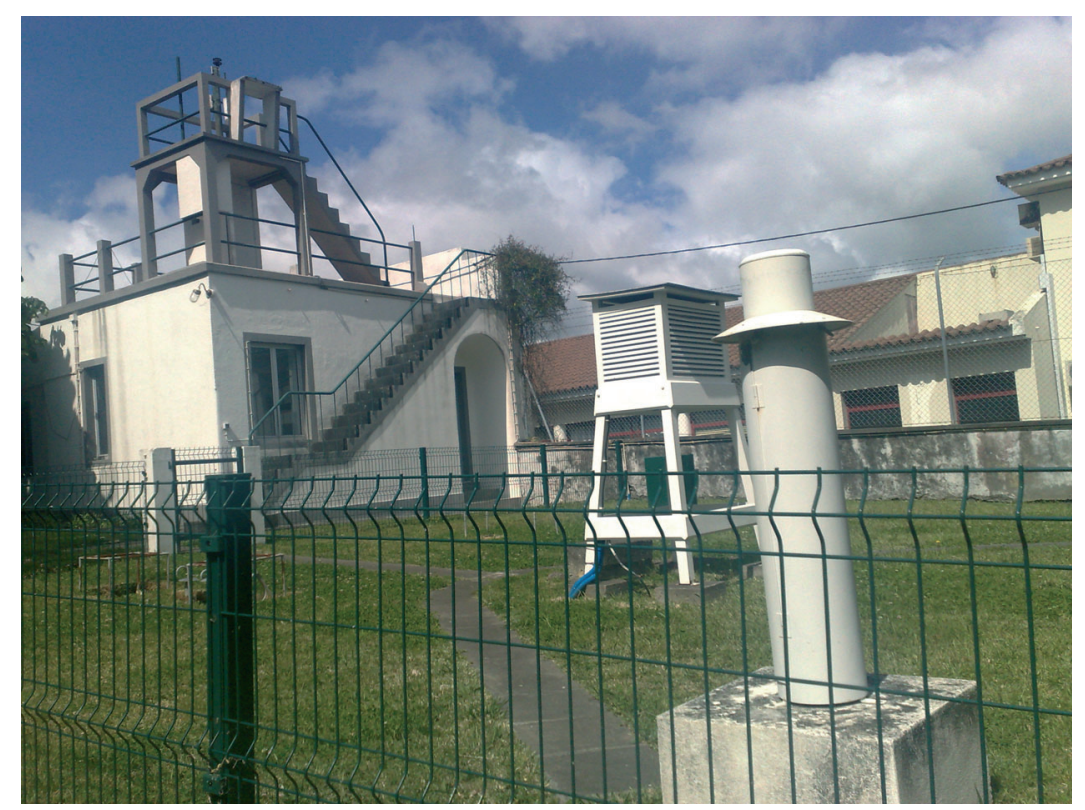

Estación meteorológica del observatorio Afonso Chaves (Ponta Delgada).

Estação meteorológica do Observatório Afonso Chaves (Ponta Delgada).

Meteorological station at the observatory of Afonso Chaves (Ponta Delgada).

Meteorológico Nacional. Debido a las condiciones topográficas de la isla, y en especial de Funchal, la información del viento incluida en el Comunicado era de la estación anemográfica instalada en la Ponta de São Lourenço, extremo este de la isla de Madeira.

A partir de 1937 la red meteorológica del Archipiélago se amplió de manera considerable.

En 1995 se instalaron en el archipiélago de Madeira las dos primeras estaciones meteorológicas automáticas (Funchal y Porto Santo). Actualmente, la red meteorológica automática de superficie, en el archipiélago de Madeira, cuenta con 15 estaciones.

\subsection{Observaciones en las Azores}

Aunque el vínculo de las Azores a la meteorología se remonta al siglo XV con el descubrimiento de los vientos alisios por Diogo de Teive, poblador de la isla Terceira, las observaciones meteorológicas más antiguas realizadas en las Azores (1817-1818) son las del geólogo americano Webster. Una descripción del clima de las Azores, así como las tablas con los resultados de las observaciones y registros gráficos de la presión y de la temperatura, realizados por Webster durante 6 meses (octubre de 1817 a marzo de 1818) se recogen en su libro "A Description of the Island of St. Michael” publicado en 1821.

En diciembre de 1818, llegan a la isla de San Miguel los hermanos Joseph y Henry Bullar. El hecho de que Joseph era médico y de que su hermano tenía tuberculosis, y también la idea extendida de las importantes ventajas que tendría para el tuberculoso el pasar el invierno en San Miguel (y no en Inglaterra) descrita en su libro "Un invierno en las Azores y un verano en el Vale das Furnas", contribuyó definitivamente en suscitar su interés a la hora de estudiar y relacionar los climas de Inglaterra, Madeira, San Miguel y otros lugares aconsejados como lugares de curación. Por ello deciden realizar observaciones meteorológicas de la temperatura y del viento en diversos lugares de San Miguel, Ponta Delgada, Vila Franca do Campo y en el Vale das Furnas. Estas observaciones se realizaron entre diciembre de 1938 y abril de 1939, estando estas tablas publicadas (Bullar, 1986).

El caso de los hermanos Bullar sería uno de los más interesantes sobre la percepción de la influencia del tiempo y del clima en la evolución de la salud humana, a semejanza de Dorno, que en Davos realizó sus primeras mediciones de radiación UV para comprender su influencia en la evolución del raquitismo.
Nacional. Devido às condições topográficas da ilha e em especial do Funchal, as informações do vento incluídas no Comunicado eram do posto anemográfico instalado na Ponta de São Lourenço, extremo leste da ilha da Madeira.

A partir de 1937 a rede meteorológica do arquipélago foi largamente ampliada.

Em 1995 foram instaladas no arquipélago da Madeira as duas primeiras estações meteorológicas automáticas (Funchal e Porto Santo). Atualmente, a rede meteorológica automática de superfície, no arquipélago da Madeira, conta com 15 estações.

\subsection{Observações nos Açores}

Muito embora a ligação dos Açores à meteorologia remonte ao século $\mathrm{XV}$ com a descoberta dos ventos Alísios por Diogo de Teive, povoador da Ilha Terceira, as observações meteorológicas mais antigas executadas nos Açores (1817-1818) são as do geólogo americano Webster. Uma descrição do clima dos Açores, bem como as tabelas com os resultados das observações e registos gráficos da pressão e da temperatura, realizados por Webster durante 6 meses (outubro de 1817 a março de 1818) encontram-se no seu livro "A Description of the Island of St. Michael" publicado em 1821.

Em dezembro de 1838, chegam à ilha de São Miguel os irmãos Joseph e Henry Bullar. O fato de Joseph ser médico e do seu irmão se encontrar tuberculoso, e ainda a divulgada ideia sobre consideráveis vantagens que para o paciente desta enfermidade teria se este passasse o inverno em São Miguel (e não em Inglaterra) descrita no seu livro "Um inverno nos Açores e um verão no Vale das Furnas”, contribuiu definitivamente para o seu interesse em estudar e relacionar os climas de Inglaterra, da Madeira, de São Miguel bem como o de outros locais aconselhados como estações de cura. Decidem pois, realizar observações meteorológicas da temperatura e do vento em diversos locais de São Miguel: Ponta Delgada, Vila Franca do Campo e no Vale das Furnas. Estas observacões realizaram-se entre dezembro de 1938 e abril de 1939, estando as estas tabelas publicadas (Bullar, 1986).

O caso dos irmãos Bullar terá sido um dos mais interessantes casos da perceção da influência do tempo e do clima na evolução da saúde humana aliás, à semelhança de Dorno, que em Davos realizou as primeiras medições de radiação UV e perceber a sua influência na evolução do raquitismo. cal Service. Due to the topographical conditions of the island and in particular Funchal, the wind information contained in the information came from the anemographic post installed at Ponta de São Lourenço, at the eastern end of Madeira.

From 1937 the meteorological network of the archipelago was widely expanded.

In 1995 the first two automatic meteorological stations were installed in the archipelago of Madeira (Funchal and Porto Santo). Currently, the automatic meteorological surface network in the archipelago has 15 stations.

\subsection{Observations in the Azores}

Although the connection of the Azores with meteorology goes back to the fifteenth century, with the discovery of trade winds by Diogo Teive, a settler from Terceira Island, the oldest meteorological observations performed in the Azores (1817-1818) are those of the American geologist Webster. A description of the climate in the Azores, as well as tables with the results of observations and graphic records of pressure and temperature, made by Webster for 6 months (October 1817 to March 1818) appear in his book "The Description of the Island of St. Michael" published in 1821.

In December 1838, the brothers Joseph and Henry Bullar arrived on the island of São Miguel. The fact that Joseph was a doctor and that tuberculosis was found in his brother, along with widespread idea about the considerable advantages that the patient with this disease would have by staying in São Miguel for the winter period (and not in England) as described in his book, "A Winter in the Azores, and a Summer at the Baths of the Furnas", definitely contributed to his interest in studying and relating the climates of England, Madeira, São Miguel and the other local stations as a recommended cure. They therefore decided to make meteorological observations of temperature and wind at several locations in São Miguel: Ponta Delgada, Vila Franca do Campo and Vale das Furnas. These observations took place between December 1938 and April 1939, these being the published tables (BulLar, 1986).

The case of the Bullar brothers has to be one of the most interesting cases in understanding the influence of weather and climate on the evolution of human health, moreover, like Dorno, who in Davos made the first UV measurements radiation and realized their influence in the evolution of rickets. 
Estación meteorológica del observatorio Príncipe Alberto de Mónaco (Horta) Estação meteorológica do Observatório Príncipe Alberto de Mónaco (Horta) Príncipe Alberto de Mónaco meteorological observatory station (Horta)

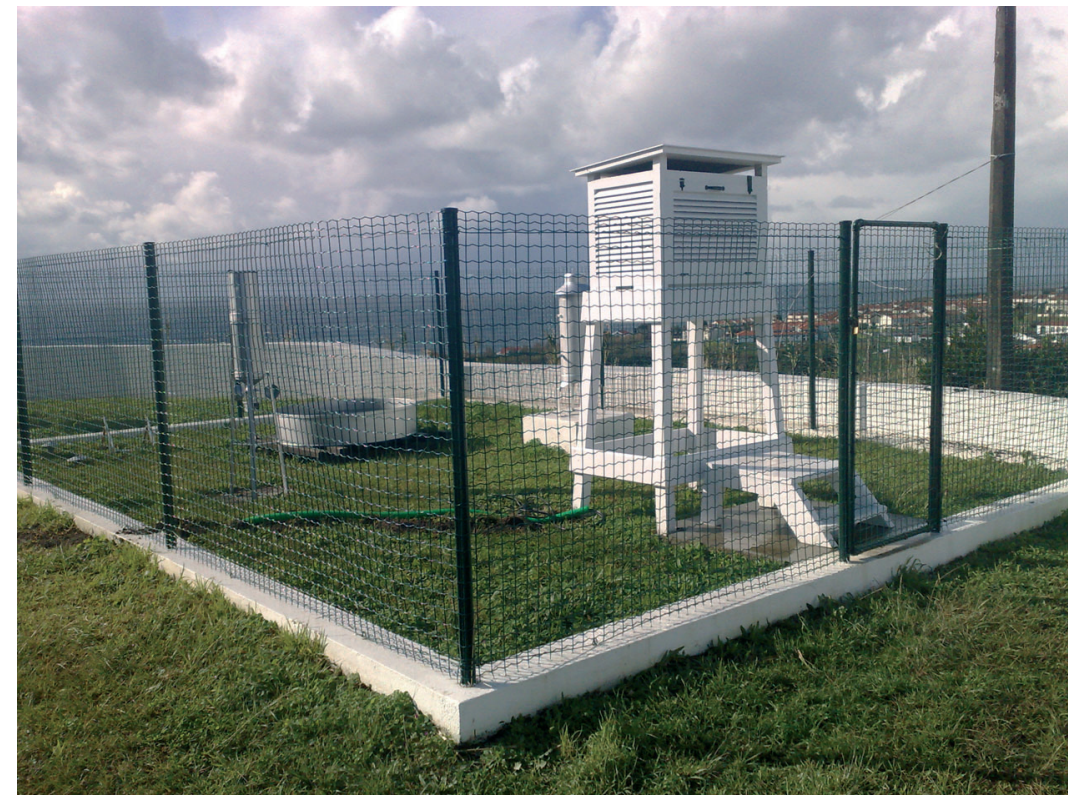

Del 1 de enero de 1840 al 31 de diciembre de 1849, Thomas Carew Hunt, Benemérito Cónsul de Su Majestad Británica en las Azores, se hizo cargo de un nuevo programa de observaciones meteorológicas: en el Almanaque Rural de las Azores del año 1951 están publicados los resultados de las observaciones de estos diez años de observaciones meteorológicas realizadas en Ponta Delgada.

También en los años cuarenta encontramos información sobre observaciones meteorológicas realizadas en San Miguel por el Capitán del Cuerpo de Ingenieros, el Sr. Caetano Alberto Maia, de diciembre de 1842 a noviembre de 1843, cuyos resultados constan en el Archivo de las Azores (1888).

Fradesso da Silveira, Director del Observatorio del Infante D. Luís (OIDL), reconociendo en el Informe de este Observatorio (1964) que "Los estudios meteorológicos en las Azores eran una necesidad reclamada desde hacía mucho por las exigencias de los científicos, tanto nacionales como extranjeros. La mayoría de las tempestades que azotan las costas occidentales de Europa, se forman en el océano Atlántico en las cercanías de las Azores, o pasan por estas islas ya formadas desde las costas del continente americano. Después de que los trabajos del Capitán Maury hiciesen especial hincapié en el estudio de las corrientes aéreas y revelaran algunas de las leyes que rigen la formación y propagación de las tempestades (ciclones), todos los pueblos cultos, viendo al alcance práctico de estos estudios, se han esforzado por conseguir un número de observaciones grande y variado, para basarse en ellas o perfeccionar la teoría, y quizá conseguir nuevos resultados", el 25 de abril de 1864 recurre a los gobernadores civiles de Ponta Delgada y de Horta y al rector del liceo de Angra do Heroísmo, solicitando ayuda para que en cada uno de estos lugares funcionase una estación meteorológica. De este modo, en enero de 1865 todas las estaciones meteorológicas previstas empiezan a funcionar.

En el Archivo de las Azores están publicados los mapas con los resúmenes de las observaciones efectuadas en la Estación Meteorológica de Ponta Delgada, en el período de 1865 a 1885, además de su publicación en los Anales del Observatorio del OIDL.

A finales del año 1935, la estación situada en la torre del antiguo Convento de la Gracia y denominada "Observatorio Afonso Chaves" fue transferida a las actuales instalaciones en el sitio de Relvão, en la costa de la ciudad.

El 1 de octubre de 1864 empezó a funcionar la Estación Meteorológica de Angra do Heroísmo, ins-
De 1 de janeiro de 1840 a 31 de dezembro de 1849, Thomas Carew Hunt, Benemérito Cônsul de Sua Majestade Britânica nos Açores, manteve sob sua responsabilidade um novo programa de observações meteorológicas: no Almanaque Rural dos Açores do ano de 1951 estão publicados os resultados das observações destes dez anos de observações meteorológicas realizadas em Ponta Delgada.

Ainda nos anos quarenta encontramos informação sobre observações meteorológicas realizadas em São Miguel pelo Capitão do corpo de Engenheiros, Sr. Caetano Alberto Maia, de dezembro de 1842 a novembro de 1843 , cujos resultados constam do Arquivo dos Açores (1888)

Fradesso da Silveira, Diretor do Observatório do Infante D. Luís (OIDL), reconhecendo no Relatório deste Observatório (1964) que "Os estudos meteorológicos nos Açores eram uma necessidade há muito reclamada pelas exigências dos homens da sciencia, tanto nacionaes como estrangeiros. A maior parte das tempestades que accometem as costas occidentaes da $\mathrm{Eu}$ ropa, forman-se no occeano atlântico nas vizinhanças dos Açores, ou passam por estas ilhas já formados das costas do continente americano. Depois, que os trabaIhos do Capitão Maury, chamaram a atenção geral para o estudo das correntes aéreas e revelaram algumas das leis, que regem a formação e propagação das tempestades (cyclones), todos os povos cultos, vendo o alcance prático de taes estudos, tem-se esforçado em alcançar grande e variado numero de observaçoes a fim de n'ellas basear ou aperfeiçoar a theoria, e porventura attingir novos resultados", a 25 de abril de 1864 oficia aos governadores civis de Ponta Delgada e da Horta e ao reitor do liceu de Angra do Heroísmo, solicitando auxilio para que em cada um daqueles locais funcionasse um posto meteorológico. Assim, sensivelmente desde janeiro de 1865 todos os postos meteorológicos previstos iniciaram o seu funcionamento.

No Arquivo dos Açores encontram-se publicados os mapas com os resumos das observações efetuadas no Posto Meteorológico de Ponta Delgada, no período de 1865 a 1885, para além da sua publicação nos Anais do Observatório do OIDL.

No fim do ano de 1935, o posto localizado na torre do antigo Convento da Graça e denominado "Observatório Afonso Chaves" foi transferido para as atuais instalações no sítio do Relvão, na orla da cidade.

A 1 de outubro de 1864 começou a funcionar o Posto Meteorológico de Angra do Heroísmo, instala-
From 1 January 1840 to December 31, 1849, Thomas Carew Hunt, Honorary Consul of His British Majesty in the Azores, was in charge of a new meteorological observation programme: In Almanaque Rural in the Azores in the year 1951 were published the results of observations of these ten years of meteorological observations made in Ponta Delgada.

Even in the forties we find information on weather observations taken in São Miguel by the Captain of the Engineer Corp, Mr. Caetano Alberto Maia, from December 1842 to November 1843, whose results appear in the Archive of the Azores (1888)

Fradesso da Silveira, Director of the Observatory of the young D. Luís (OIDL), recognising in the report of the Observatory (1964) stating "The meteorological studies in the Azores were a necessity long-claimed by the demands of men of science, both nationals and foreigners. Most of the storms that afflict the western coast of Europe are formed in the Atlantic Ocean, in the vicinity of the Azores, or pass through these islands having formed on the back of the American continent. After that the work of Captain Maury drew general attention to the study of air currents and revealed some of the laws governing the formation and propagation of storms (cyclones), all those learned people seeing the practical range of such studies, have been pushed to reach a large and varied number of observations in order to build or improve on that theory, and to perbaps strike new results", on $25^{\text {th }}$ of April 1864 officiates to the civil governors of Ponta Delgada and Horta and the Dean of the school of Angra do Heroísmo, asked for help so that a meteorological station could be put into operation in each of those sites. Thus, significantly al meteorological stations started their operation from January 1865 .

In the Archive of the Azores there are maps published with summaries of the observations made in the Meteorological Station of Ponta Delgada in the period 1865 to 1885 , as well as publications in the Annals of the Observatory of OIDL.

In late 1935, the post located in the tower of the former Convent of Grace and named the "Afonso Chaves Observatory" was transferred to existing facilities at the site of Relvão, on the outskirts of the town.

On the 1 of October 1864 the Meteorological Station of Angra do Heroism began its operation, 


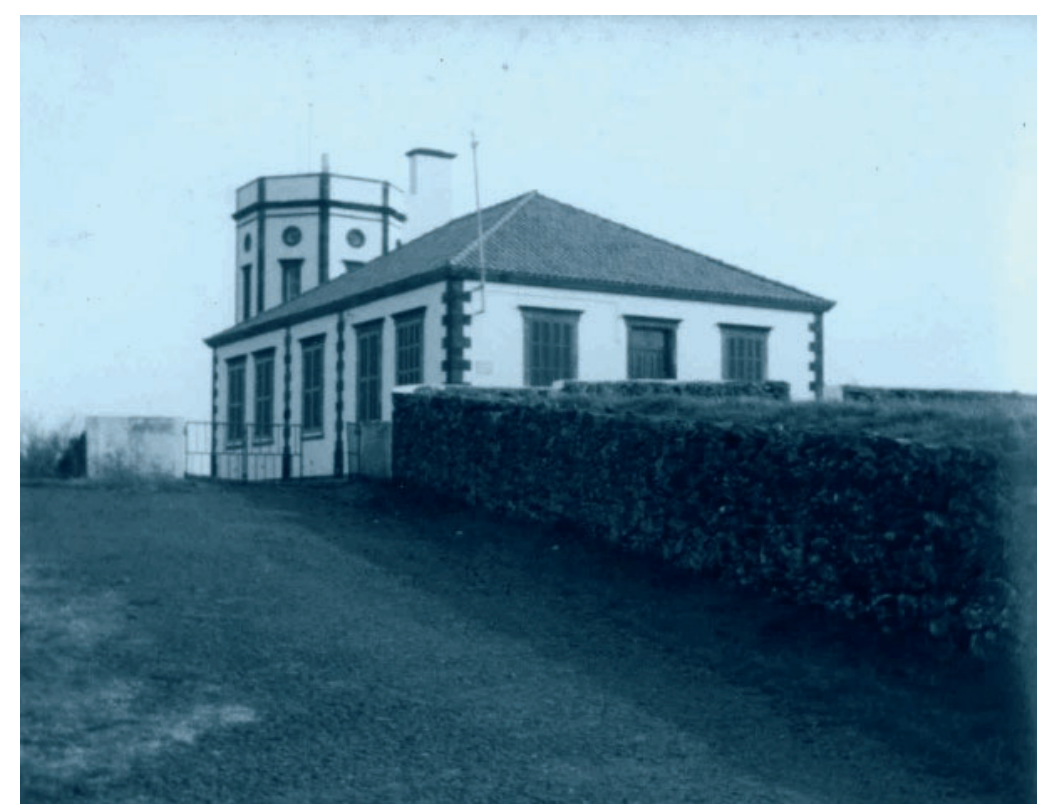

Observatorio de la isla de Flores (1980).

Observatório das Flores (1980).

Observatory of "das Flores" (1980).

talada en el liceo de la misma ciudad. Los resultados de las observaciones de diciembre de ese mismo año están publicados en los Anales del Observatorio del OIDL. En 1879 la estación se transfiere al atrio de la torre de la iglesia del Colegio, donde funcionó hasta finales de 1940, siendo transferida, ya con la designación de Observatorio, a las actuales instalaciones en el sitio de Santa Luzia, en la costa de la ciudad. El 10 de noviembre de 1976, manda el Gobierno de la República Portuguesa, a través de los Ministros de la República para las Azores y de Transportes y Comunicaciones, que el Observatorio del Servicio Meteorológico Nacional en Angra do Heroísmo se denomine "Observatorio José Agostinho".

En 1857 el OIDL al servicio de la meteorología internacional enviaba los resultados de las observaciones a su congénere en París. En ese momento Portugal ya estaba conectado mediante telégrafo al resto de Europa. En este mismo año se publicaban en el Boletín Internacional registros de más de cincuenta observatorios y estaciones meteorológicas.

Habiendo funcionando en la ciudad de Horta (isla de Faial) una estación meteorológica en el período de 1857 a 1858, solo a partir de enero de 1901 comenzó su funcionamiento en la terraza del edificio del Gobierno Civil. En julio de 1915 esa estación, ya denominada “Observatorio del Príncipe de Mónaco”, fue transferida a las actuales instalaciones en el Monte das Moças.

En 1897, en Santa Cruz (isla de Flores), empezaron a realizarse observaciones meteorológicas regulares en la estación meteorológica instalada en una dependencia de la casa en la que funcionaba la sección de Obras Públicas. Esta estación se trasladó en 1921 al nuevo edificio construido en el Castelo do Moio.

El 28 de agosto de 1893 se inauguró la conexión por cable submarino entre Ponta Delgada y Cascais. Por fin se reunían las condiciones para que el proyecto del Príncipe de Mónaco, apoyado por el director del Servicio Meteorológico Francés, se realizase: este proyecto pretendía crear observatorios en las principales islas del océano y lejos de los continentes. El cable permitía también utilizar los resultados de las observaciones meteorológicas realizadas en las Azores en la previsión del tiempo.

El 12 de junio de 1901 y por Carta de Ley, fue instituido el Servicio Meteorológico de las Azores, con sede en Ponta Delgada, siendo su primer director el Capitán Francisco Afonso Chaves. El Servicio do no liceu da mesma cidade. Os resultados das observações de dezembro desse mesmo ano encontram-se publicados nos Anais do Observatório do OIDL. Em 1879 o posto foi transferido para o eirado da torre da igreja do Colégio, onde funcionou até ao fim de 1940, tendo sido transferido, já com a designação de Observatório, para as atuais instalações no sítio de Santa Luzia, na orla da cidade. A 10 de novembro de 1976, manda o Governo da República Portuguesa, pelos Ministros da República para os Açores e dos Transportes e Comunicações, que o Observatório do Serviço Meteorológico Nacional em Angra do Heroísmo seja denominado "Observatório José Agostinho".

Em 1857, o OIDL ao serviço da meteorologia internacional, enviava os resultados das observações para o seu congénere em Paris. Nesta altura já Portugal se encontrava ligado pelo telégrafo ao resto da Europa. Neste mesmo ano, eram publicadas no Boletim Internacional registos de mais de cinquenta observatórios e postos meteorológicos.

Na cidade da Horta (ilha do Faial) tendo funcionado um posto meteorológico no período de 1857 a 1858, só a partir de janeiro de 1901 iniciou o seu funcionamento no terraço do edifício do Governo Civil. Em julho de 1915 esse posto, já denominado "Observatório do Príncipe do Mónaco", foi transferido para as atuais instalações no Monte das Moças.

Em 1897, em Santa Cruz (ilha das Flores), começaram a executar-se observações meteorológicas regulares no posto meteorológico instalado numa dependência da casa onde funcionava a secção de Obras Públicas. Este posto foi transferido em 1921 para o novo edifício construído no Castelo do Moio.

A 28 de agosto de 1893 foi inaugurada a ligação por cabo submarino entre Ponta Delgada e Cascais. Estavam finalmente reunidas as condições para que o projeto do Príncipe do Mónaco, apoiado pelo diretor do Serviço Meteorológico Francês, se realizasse: este projeto visava a criação de Observatórios nas principais ilhas do Oceano e longe dos continentes. O cabo permitia ainda que os resultados das observações meteorológicas executadas nos Açores pudessem ser utilizados na previsão do tempo.

A 12 de junho de 1901 e por Carta de Lei, foi instituído o Serviço Meteorológico dos Açores, com sede em Ponta Delgada, tendo sido o seu primeiro diretor o Capitão Francisco Afonso Chaves. O Servi- installed at the high school of the town. The results of observations in December of that year are published in the Annals of the Observatory of OIDL. In 1879 the station was transferred to the roof of the church tower of the College, where it operated until the end of 1940, having been transferred to the current facilities at the site of Santa Luzia on the outskirts of town, it was now known as the Observatory. On 10 November, 1976, by means of the Ministers of the Republic for the Azores and Transport and Communications, the Government of the Portuguese Republic ordered the National Meteorological Observatory Centre in Angra do Heroism to be called the "José Agostinho Observatory".

In 1857 the OIDL, the service of international meteorology, sent the results of the observations to their counterpart in Paris. By this time Portugal was linked by telegraph to the rest of Europe. That same year records of more than fifty observatories and weather stations were published in the International Bulletin.

In the city Horta (Island of Faial) having operated a meteorological station during the period 1857 to 1858 , it was only from January 1901 that operations started from the terrace of the Civil Government. In July 1915 the post, now called the "Príncipe do Mónaco Observatory", was transferred to existing facilities on Monte das Moças.

In 1897, in Santa Cruz (Island of Flores), regular meteorological operations began at the meteorological station installed in a dependence of the house where it operated in the public works section. In 1921 this station was transferred to the new building constructed in the Castelo do Moio Castle.

On $28^{\text {th }}$ August 1893 the undersea cable linking Ponta Delgada and Cascais was inaugurated. Conditions where now in place for the Prince of Monaco project, supported by the Director of the French Meteorological Service, to get up and running. This project aimed at setting up observatories on the main islands of the Ocean and far away from the continents. Furthermore the cable made it possible for the results from the meteorological observations performed in the Azores to be used in weather forecasting.

On the 12 of June 1901 and by Letter of Law, the Meteorological Service of the Azores was instituted, based in Ponta Delgada, and Captain Francisco Afonso Chaves was its first Director. The Meteoro- 
Estación meteorológica del aeropuerto de Santa María Estação meteorológica do Aeroporto de Santa Maria. Meteorological station of the Airport of Santa Maria.

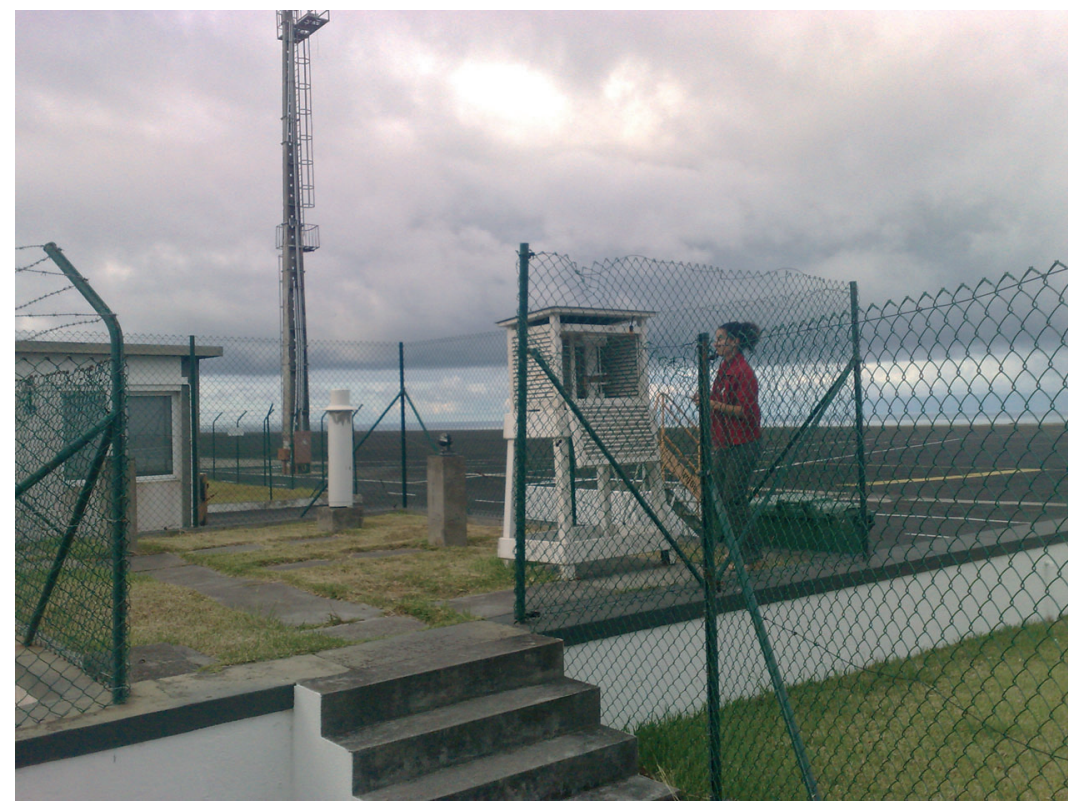

Meteorológico de las Azores fue extinguido por el Decreto-Ley n. ${ }^{\circ} 35$ 836, el 29 de agosto de 1946, e incorporado a partir del 1 de octubre del mismo año al Servicio Meteorológico Nacional instituido en el mismo documento.

En el altiplano de Achada das Furnas (San Miguel), a $550 \mathrm{~m}$ de altitud, funciona desde el verano de 1935 una estación meteorológica inicialmente mantenida por la Junta General del Distrito de Ponta Delgada.

En los aeródromos de Santa María, Santana (San Miguel) y Lajes (Terceira) se han realizado observaciones meteorológicas desde 1943 o 1944, inicialmente a cargo de las fuerzas aéreas británicas o de los EE.UU. que prestaban servicio en ellos.

En Corvo la estación meteorológica funciona desde septiembre de 1945, instalada junto a la estación radiotelegráfica de Correos y Telégrafos.

La instalación de estaciones pluviométricas, iniciada en 1916 en la Fajã de Cima (Observatorio Magnético), Ferraria, en San Miguel y en los Capelinhos, en Faial, se expandió rápidamente a partir de 1935 y en todo el archipiélago.

Actualmente en las Azores, la red de superficie está constituida, además de por las nueve estaciones meteorológicas para fines sinópticos, climatológicos y de aeronáutica, instaladas en los aeródromos, por dos observatorios más (San Miguel y Faial) ejecutando programas de observación con fines sinópticos y climatológicos, un observatorio (Terceira) con programas de observación con fines sinópticos, climatológicos, radiación y composición de la atmósfera y tres estaciones climatológicas. Diversas estaciones pluviométricas dispersas en el archipiélago son controladas por varias instituciones regionales además del Instituto de Meteorología. Funciona también en las Lajes (Terceira) una estación aerológica, operada por la Fuerza Aérea Portuguesa.

Los resultados de las observaciones meteorológicas, utilizados para realizar este Atlas, proceden del sistema clásico de estaciones meteorológicas manipuladas. ço Meteorológico dos Açores foi extinto pelo Decreto-Lei n. 35 836, de 29 de agosto de 1946, e incorporado a partir a 1 de outubro do mesmo ano no Serviço Meteorológico Nacional instituído no mesmo diploma.

No planalto da Achada das Furnas (São Miguel), a $550 \mathrm{~m}$ de altitude funciona, desde o verão de 1935 , uma estação meteorológica inicialmente mantida pela Junta Geral do Distrito de Ponta Delgada.

Nos aeródromos de Santa Maria, Santana (São Miguel) e Lajes (Terceira) executam-se observações meteorológicas desde 1943 ou 1944, inicialmente a cargo das forças aéreas britânicas ou dos EUA que neles prestavam serviço.

No Corvo, a estação meteorológica funciona desde setembro de 1945, instalada junto ao posto radiotelegráfico dos CTT.

A instalação de postos udométricos, iniciada em 1916 na Fajã de Cima (Observatório Magnético), Ferraria, em São Miguel e nos Capelinhos, no Faial, teve rápida expansão a partir de 1935 e em todo o arquipélago.

Atualmente nos Açores, a rede de superfície é constituída, além das nove estações meteorológicas para fins sinópticos, climatológicos e de aeronáutica, instaladas nos aeródromos, por mais 2 Observatórios (São Miguel e Faial) executando programas de observação para fins sinópticos e climatológicos, 1 Observatório (Terceira) com programas de observação para fins sinópticos, climatológicos, radiação e composição da atmosfera e 3 estações climatológicas. Diversas estações udométricas dispersas no Arquipélago são operadas por diversas instituições regionais para além do Instituto de Meteorologia. Funciona ainda nas Lajes (Terceira) uma estação aerológica, operada pela Força Aérea Portuguesa.

Os resultados das observações meteorológicas, utilizados para a realização deste Atlas resultaram do sistema clássico de estações meteorológicas manipuladas. logical Service of the Azores was abolished by Decree-Law No. 35836 on 29 August 1946, and the National Meteorological Service was built from the 1 st of October of the same year and established under the same Act.

On the plateau of Achada Furnas (São Miguel) at an altitude of $550 \mathrm{~m}$, a meteorological station, initially maintained by the General Board of the Dis trict of Ponta Delgada, has operated since the summer of 1935

From airfields in Santa Maria, Santana (São Miguel) and Lajes (Terceira) meteorological observations were carried out from 1943 or 1944, initially in the charge of the British and U.S Air Forces to whom they provided services.

In Corvo, the meteorological station has been operating since September 1945, located at the radiotelegraph station of the CTT.

The installation of udometric posts begun in 1916 in "Fajã de Cima" (Magnetic Observatory), Ferraria in São Miguel and Capelinhos in Faial. It saw a rapid expansion from 1935 and throughout the archipelago.

Currently in the Azores, the surface network is constituted, apart from the nine weather stations for synoptic, climatological and aeronautic purposes, installed at the airfields, by two other Observatories (São Miguel and Faial). These carry out observation programmes for synoptic and climatological purposes. One Observatory (Terceira) with observation programmes for synoptic, climatological, radiation and atmospheric purposes and three meteorological stations. Several udometric stations scattered across the archipelago are operated by several regional institutions outside of the Institute of Meteorology. There is even an aerological station in Lajes (Terceira) operated by the Portuguese Air Force.

The results of the meteorological observations used in the preparation of this Atlas come from the classical system of meteorological stations. 



\section{Metodología}

\subsection{Normales climatológicas}

Las normales climatológicas se refieren a cálculos estadísticos realizados sobre valores climáticos de magnitudes meteorológicas observadas, en un determinado lugar y en un determinado período de tiempo. El uso de un período de 30 años es un convenio adoptado internacionalmente por la Organización Meteorológica Mundial (OMM) y se asume como un período suficiente para filtrar las fluctuaciones de menor escala temporal de las observaciones del clima como, por ejemplo, la variabilidad interanual.

Los períodos de referencia de 30 años se denominan Normales Climatológicas de Referencia: 1901-1930, 1931-1960, 1961-1990, aunque la OMM recomienda también actualizar las normales climatológicas al final de cada década, obteniendo así las normales intermedias como las de 1971-2000 (WMOTD/No. 341).

El proceso de las normales climatológicas se realiza sobre series de datos de observación, debidamente validados por procesos de control de calidad, siguiendo las recomendaciones establecidas por la $\mathrm{OMM}$, en lo que se refiere a los procedimientos de validación de la información meteorológica y a los criterios a adoptar en situaciones de ausencia de datos (WMO, 1983).

Para calcular las normales 1971-2000 se determinan, a partir de los datos diarios, en primer lugar los valores mensuales de cada parámetro, que servirán de base para determinar los valores anuales y, a continuación, los valores medios en los 30 años. La normal anual se obtiene calculando la media (para la temperatura) o el total acumulado (para la precipitación) de los valores normales mensuales.

Los resultados presentados siguen las definiciones adoptadas internacionalmente para las estaciones del año, en términos climatológicos, donde el invierno incluye los meses de diciembre, enero y febrero, la primavera incluye los meses de marzo, abril y mayo, el verano incluye los meses de junio, julio y agosto y el otoño incluye los meses de septiembre, octubre y noviembre.

\subsection{Cartografía}

La cartografía de la temperatura del aire y de la precipitación se obtuvo recurriendo a métodos de interpolación disponibles en software de Sistemas de Información Geográfica.

Teniendo en cuenta la diversidad geográfica de este trabajo, la selección de los métodos de interpolación a aplicar se efectuó consultando otros trabajos realizados para el territorio considerado, pero también mediante ensayos sucesivos, probando varios métodos disponibles.

Para la temperatura del aire y número de días con temperatura superior o inferior a determinados límites, se ha utilizado en cada uno de los archipiélagos, Azores, Madeira y Canarias, una regresión lineal múltiple con la altitud, latitud y longitud, como variables auxiliares, interpolándose la componente residual mediante Inverse Distance Weighting (IDW).

\section{Metodologia}

\subsection{Normais climatológicas}

As normais climatológicas referem-se a cálculos estatísticos realizados sobre valores climáticos de grandezas meteorológicas observadas, num determinado local e num determinado período de tempo. A utilização de um período de 30 anos é uma convenção adotada internacionalmente pela Organização Meteorológica Mundial (OMM) e assume-se como um período suficiente para que sejam filtradas as flutuações de menor escala temporal do clima observado, como, por exemplo, a variabilidade interanual.

Os períodos de referência de 30 anos são designados por Normais Climatológicas de Referência: 19011930, 1931-1960, 1961-1990, no entanto a OMM recomenda também, que as normais climatológicas sejam atualizadas no fim de cada década, obtendo-se assim as normais intercalares como as de 1971-2000 (WMO-TD/No. 341).

O processamento das normais climatológicas é efetuado sobre séries de dados observacionais, devidamente validados por processos de controlo de qualidade, seguindo as recomendações estabelecidas pela OMM, no que diz respeito aos procedimentos de validação da informação meteorológica e aos critérios a adotar em situações de ausência de dados (WMO, 1983).

Para o cálculo das normais 1971-2000 determinam-se, a partir dos dados diários, primeiro os apuramentos dos valores mensais de cada parâmetro, com base nos quais se determinam os valores anuais e em seguida os valores médios nos 30 anos. A normal anual é calculada pela média (para a temperatura) ou pelo total (para a precipitação) dos valores normais mensais.

Os resultados apresentados seguem as definições adotadas internacionalmente para as estações do ano, em termos climatológicos, em que o inverno inclui os meses de dezembro, janeiro e fevereiro, a primavera inclui os meses de març, abril e maio, o verão inclui os meses de junho, julho e agosto e o outono inclui os meses de setembro, outubro e novembro.

\subsection{Cartografia}

A obtenção da cartografia da temperatura do ar e da precipitação foi efetuada recorrendo a métodos de interpolação disponíveis em software de Sistemas de Informação Geográfica.

Tendo em conta a diversidade geográfica deste trabalho, a seleção dos métodos de interpolação a aplicar, foi efetuada consultando outros trabalhos realizados para o território considerado, mas também por aproximações, testando vários métodos disponíveis.

Para a temperatura do ar e número de dias com temperatura acima ou abaixo de determinados limites, utilizou-se em cada um dos arquipélagos, Açores, Madeira e Canárias, a regressão linear múltipla com a altitude, latitude e longitude, como variáveis auxiliares, interpolando-se a componente residual através de Inverse Distance Weighting (IDW).

\section{Methodology}

\subsection{Climate normals}

Climatic normals refer to statistical calculations performed on climatic values of meteorological quantities observed in a given location and within a given time period. The use of a period of 30 years is a convention used by the World Meteorological Organization (WMO) and is assumed as a sufficient period for observing fluctuations on a smaller climate timescale, for example, in the observation of interannual variability.

The reference periods of 30 years are called climatological normals of Reference: 1901-1930, 19311960, 1961-1990, however the WMO recommends that the climatological normals are updated at the end of each decade, thus obtaining interim normals such as those of 1971-2000 (WMO-TD/No. 341).

The processing of the climatological normals is carried out on observational data sets, duly validated by quality control processes, following the recommendations established by the WMO with regard to validation procedures of meteorological information and the criteria to be adopted in the event of absence of data (WMO, 1983).

For calculation of the normals of 1971-2000, it is firstly determined, from daily data, the findings of the monthly values of each parameter, on which the annual average values based and subsequently the average over 30 years is determined. An annual normal is calculated by the average (for temperature) or total (for precipitation) of the monthly values of the normals.

The results presented follow the internationally accepted definitions for the seasons, in climatological terms, which includes for the winter months December, January and February, for spring the months of March, April and May, for summer the months of June, July and August and for autumn the months of September, October and November.

\subsection{Cartography}

Obtaining the mapping of air temperature and precipitation was performed using interpolation methods available from Geographic Information Systems software.

Given the geographic diversity of this work, the selection of interpolation methods to be applied was made in consultation with other work carried out for the territory in question, but also by means of approximations and testing various available methods

For the air temperature and number of days with temperatures above or below certain limits, the method used in each of the archipelagos, the Azores, Madeira and the Canary Islands, was the multiple linear regression method, with altitude, latitude and longitude as auxiliary variables, interpolating the residual component by means of Inverse Distance Weighting (IDW). 

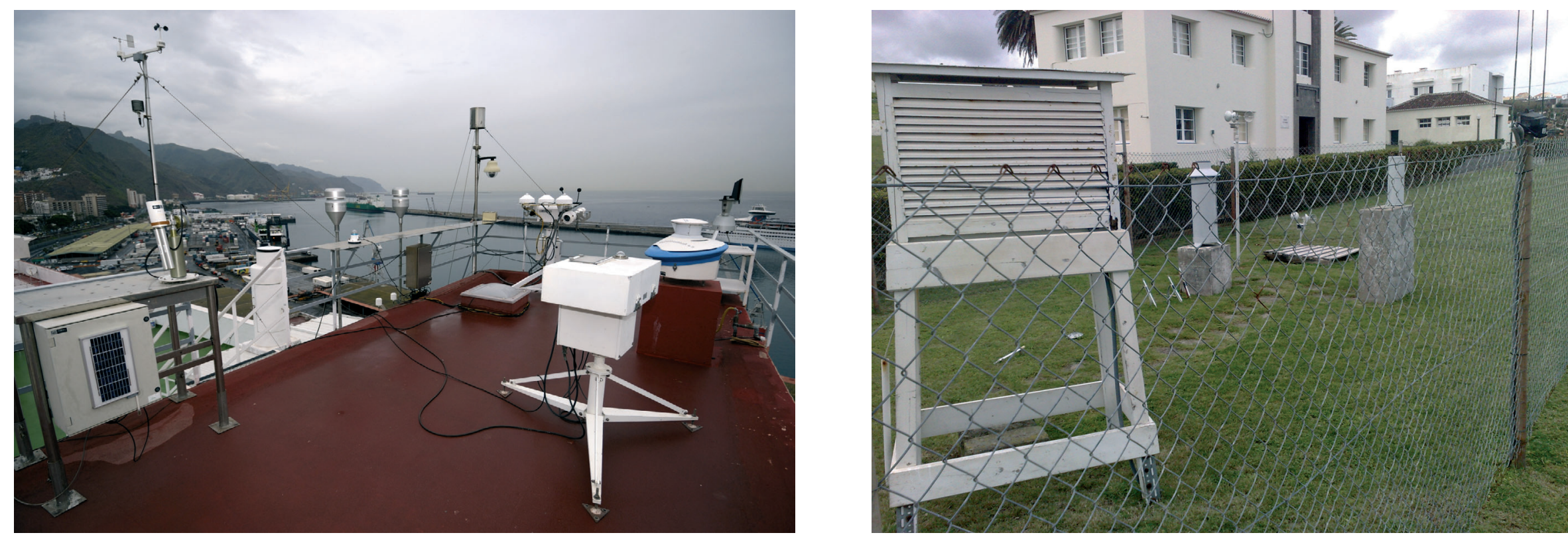

Azotea del Centro de investigación atmosférica de Izaña (Sta. C. de Tenerife—Canarias) (izquierda) y Estación meteorológica del observatorio “José Agostinho” (Angra do Heroísmo-Azores) (derecha).

Terraço do Centro de investigación atmosférica de Izanha (Santa Cruz de Tenerife-Canárias) (esquerda) e Estação meteorológica do observatório "José Agostinho" (Angra do Heroísmo-Açores) (direita).

Flat roof of the Centro de investigación atmosférica of Izanha (Santa Cruz de Tenerife-Canary Islands) (left) and José Agostinho meteorological observatory station (Angra do Heroísmo-Azores) (right).

En el caso de la precipitación, la gran variabilidad de este elemento, muy influenciado por factores locales, ha dificultado bastante la tarea de modelado, aplicándose un método diferente en cada archipiélago. En las Azores se ha utilizado la regresión lineal múltiple con la altitud, latitud y longitud como variables auxiliares e IDW de los residuos. La inexistencia de estaciones pluviométricas a cotas de altitud superiores a 1000 metros hace que exista una extrapolación, sobre todo en la montaña de Pico, en la isla de Pico. De este modo, se ha optado por colocar una máscara "sin información” (no data) en las estimaciones mensuales y anual de precipitación por encima de la cota de los 1200 metros, ya que no parece aceptable que los valores de precipitación sigan aumentando a partir de determinada cota de altitud (más bien al contrario) y que en la cima del Pico se registren valores de precipitación más elevados que en el altiplano, como indicaba el modelo de regresión. En el caso del número de días con precipitación $\geq 0,1 \mathrm{~mm}$ y $\geq 1 \mathrm{~mm}$ se ha utilizado un krigeado normal, un método de interpolación univariado, dada la escasa relación con los factores físicos referidos.

En Madeira el método aplicado en el modelado de la precipitación ha sido una regresión polinomial de $2 .^{\circ}$ grado con la altitud, latitud y longitud como variables auxiliares. La interpolación tuvo como limitación la baja densidad de la red de observación para la complejidad y variabilidad del campo de la precipitación existente en esta isla. También debemos mencionar que una extensión considerable de la isla de Madeira (región oeste) carece de observaciones en el período considerado (área sujeta a extrapolación). También en la isla de Porto Santo se disponía únicamente de datos de una estación por lo que, al contrario de lo que se hizo con la temperatura, en este caso no se ha aplicado el modelo de regresión, construido a partir de los valores de las estaciones de la isla de Madeira, habiéndose atribuido a toda la isla el valor de precipitación observado en la estación de Porto de Santo/Aeropuerto. Sin embargo, es importante mencionar que, aunque no existan cotas
No caso da precipitação, a grande variabilidade deste elemento, fortemente influenciado por fatores locais, dificultou bastante a tarefa de modelação, tendo sido aplicados diferentes métodos por arquipélago. Nos Açores utilizou-se a regressão linear múltipla com a altitude, latitude e longitude como variáveis auxiliares e IDW dos resíduos. A inexistência de estações ou postos udométricos a cotas de altitude superiores a 1000 metros faz com que haja uma extrapolação, sobretudo na montanha do Pico, na ilha do Pico. Deste modo, optou-se por colocar uma máscara "sem informação" (no data) nas estimativas mensais e anual de precipitação acima da cota de 1200 metros, porque não parece aceitável que os valores de precipitação continuem a aumentar a partir de determinada cota de altitude (antes pelo contrário) e que no topo do Pico ocorram valores de precipitação mais elevados que no planalto, como indicava o modelo de regressão. No caso do número de dias com precipitação $\geq 0,1 \mathrm{~mm}$ e $\geq 1 \mathrm{~mm}$ utilizou-se a krigagem normal, um método de interpolação univariado, dada a muito fraca relação com os fatores físicos referidos.

Na Madeira o método aplicado na modelação da precipitação foi a regressão polinomial de 2 o grau com a altitude, latitude e longitude como variáveis auxiliares. A interpolação teve como limitação a densidade da rede de observação para a complexidade e variabilidade do campo da precipitação existente nesta ilha. De referir ainda que uma considerável extensão da ilha da Madeira (região Oeste) não tem observações no período considerado (área sujeita a extrapolação). Também na ilha de Porto Santo apenas se dispunha de dados de uma estação, pelo que, ao contrário do que se fez com a temperatura, neste caso, não se aplicou o modelo de regressão, construído com base nos valores das estações da ilha da Madeira, tendo-se atribuído a toda a ilha o valor de precipitação observado na estação de Porto de Santo/Aeroporto. Não obstante, é importante mencionar que, ainda que se não verifiquem cotas de altitude elevada na ilha, os
In the case of precipitation, the great variability of this element, strongly influenced by local factors, greatly hindered the model, having applied different methods according to each archipelago. In the Azores, the multiple linear regression method was used with altitude, latitude and longitude as auxiliary variables and IDW was used for residual components. The lack of udometric stations or posts at altitudes of over 1000 meters means extrapolation is necessary, especially on Mount Pico on Pico Island. Thus, it was decided to cover a gap where there was no information (regarding date) with a "bandage" covering the monthly and annual estimates of precipitation over the height of 1200 meters. This is because it does not seem acceptable that the precipitation values would continue to increase over a certain altitude (previously to the contrary) and that on the peak of Mount Pico there are precipitation values higher than on the plateau, as indicated by the regression model. In the case of the number of days with precipitation being $\geq 0.1 \mathrm{~mm}$ and $\geq 1 \mathrm{~mm}$ the krigagem normal is used, an unvaried interpolation method, due to the minimal relationship with said physical factors.

In Madeira, the method applied in the precipitation model was the second degree polynomial regression model with altitude, latitude and longitude as auxiliary variables. The interpolation was limited to the density of the observation network for the complexity and variability of the precipitation field existing on this island. It should also be noted that a considerable extension of the Island of Madeira (western part) has no recorded observations during the period in question (area subject to extrapolation). Moreover on the island of Porto Santo data was only available from one station, therefore, contrary to that carried out with the temperature, in this case the regression model was not applied, constructed based on the values of the stations on the island of $\mathrm{Ma}$ deira, the value of precipitation observed at the station of Porto Santo/Airport was assigned to the island. Nevertheless, it is important to mention that 
de altitud elevada en la isla, los relieves existentes (Pico do Castelo, Pico do Facho, Pico Juliana...), pueden ser suficientes para que exista cierta diferenciación espacial en la distribución de la precipitación en la isla de Porto Santo.

En las Canarias la complejidad de la distribución espacial de la precipitación debido a la orografía, con máximos de precipitación que se producen en las cotas de altitud intermedias, en las vertientes orientadas al norte y noroeste, ha dificultado la aplicación de modelos de regresión con variables explicativas, como la altitud. Sin embargo, la elevada densidad de estaciones pluviométricas ha permitido la aplicación satisfactoria de un krigeado universal con la altitud como variable auxiliar, de tal modo que la variación local de la precipitación con la altitud se tiene en cuenta en la interpolación, siendo diferente para las diversas cotas de altitud y exposición de vertientes.

Para la interpolación del número medio de días de precipitación superior a determinados umbrales $(0,1 \mathrm{~mm}, 1,0 \mathrm{~mm}, 10,0 \mathrm{~mm}$ y $30,0 \mathrm{~mm})$, debido a que el número de observaciones es mucho menor, en comparación con los totales de precipitación, se ha optado por aplicar un krigeado universal local considerando como variable auxiliar el campo de la precipitación total anual media obtenido anteriormente, en lugar de la altitud.

En relación a la validación de las rejillas obtenidas y además de las consideraciones descritas anteriormente sobre las dificultades de modelado de algunos elementos hay que mencionar que los valores del error —obtenidos por validación cruzada — de las diversas rejillas dependen de la variabilidad de cada elemento y de la densidad de la red de estaciones correspondiente, así como también de la correlación con las variables explicativas utilizadas y, en particular, con la altitud.

\section{Sistema de proyección}

El sistema de referencia adoptado ha sido el ITRF93 (International Terrestrial Reference Frame 1993), recomendado por el Instituto Geográfico Portugués (IGP) para las Azores y para Madeira y equivalente al sistema de referencia geodésico REGCAN95, oficial en España para las islas Canarias. Aunque el IGP sugiere una aplicación de la proyección cartográfica Universal Transversal de Mercator (UTM) según los husos en que se encuentra cada región, se optó por utilizar para todas las islas de las Azores el UTM26N ya que el meridiano central está a $27^{\circ} \mathrm{W}$ y dista unos $4^{\circ}$ de la isla de Flores, la más occidental (cerca de $31,25^{\circ} \mathrm{W}$ ), no provocando una distorsión que impida su uso y permitiendo utilizar una rejilla para este territorio.

A continuación se presentan los respectivos parámetros:

\section{Azores:}

\section{ITRF93/UTM 26N}

Elipsoide de referencia: GRS80 (Geodetic Reference System 1980)

Proyección cartográfica: UTM (Universal Transversal de Mercator) - huso 26

Latitud del origen de las coordenadas rectangulares: $0^{\circ}$

Longitud del origen de las coordenadas rectangulares: $27^{\circ} \mathrm{W}$

Falso origen de las coordenadas rectangulares: En E (Easting): $500000 \mathrm{~m}$

En N (Northing): $0 \mathrm{~m}$

Factor de escala en el meridiano central: 0,9996 relevos que existem (Pico do Castelo, Pico do Facho, Pico Juliana...), podem ser suficientes para que haja alguma diferenciação espacial na distribuição da precipitação na ilha de Porto Santo.

Nas Canárias a complexidade da distribuição espacial da precipitação devido à orografia, com máximos de precipitação que ocorrem nas cotas de altitude intermédias, nas vertentes orientadas a norte $\mathrm{e}$ nordeste, dificultou a aplicação de modelos de regressão com variáveis explicativas, como a altitude. Contudo, a densidade de postos udométricos, permitiu a aplicação satisfatória da krigagem universal com a altitude como covariável, de tal modo que a variação local da precipitação com a altitude é tida em conta na interpolação, sendo diferente para as várias cotas de altitude e exposição de vertentes.

Para a interpolação do número médio de dias de precipitação superior a determinados limiares $(0,1 \mathrm{~mm}$, $1,0 \mathrm{~mm}, 10,0 \mathrm{~mm}$ e $30,0 \mathrm{~mm}$ ), devido ao número muito inferior de observações, comparativamente aos totais de precipitação, optou-se por aplicar a krigagem universal local, considerando como variável auxiliar o campo da precipitação total anual média, obtido anteriormente, em detrimento da altitude.

Relativamente à validação das grelhas obtidas e para além das considerações descritas anteriormente, sobre as dificuldades de modelação de alguns elementos, é de referir que os valores de erro, obtidos por validação cruzada, das diversas grelhas, estão em geral de acordo com a maior ou menor variabilidade do elemento em análise e respectiva densidade de rede de estações, mas também, com a relação com as variáveis explicativas utilizadas, em particular, com a altitude.

\section{Sistema de projeção}

O sistema de referenciação adotado foi o ITRF93 (International Terrestrial Reference Frame 1993), recomendado pelo Instituto Geográfico Português (IGP) para os Açores e para a Madeira e o equivalente ao sistema de referência geodésico REGCAN95, oficial em Espanha, para as ilhas Canárias. Embora o IGP, sugira uma aplicação da projeção cartográfica Transversa de Mercator Universal (UTM) segundo os fusos em que se encontra cada região, foi sugerido para os Açores utilizar para todas as ilhas o UTM26N uma vez que o meridiano central é a $27^{\circ} \mathrm{W}$ e dista cerca de $4^{\circ}$ da ilha das Flores, mais ocidental (cerca de $31,25^{\circ} \mathrm{W}$ ), não provocando uma distorção que impeça a sua utilização e possibilitando uma grelha única para este território.

Seguidamente apresentam-se os respetivos parâmetros:

\section{Açores:}

ITRF93/UTM 26N

Elipsoide de referência: GRS80 (Geodetic Reference System 1980)

Projeção cartográfica: UTM (Universal Transverse Mercator) - fuso 26

Latitude da origem das coordenadas retangulares: $0^{\circ}$

Longitude da origem das coordenadas retangulares: $27^{\circ} \mathrm{W}$

Falsa origem das coordenadas retangulares:

Em E (Easting): $500000 \mathrm{~m}$

Em N (Northing): $0 \mathrm{~m}$

Fator de escala no meridiano central: 0,9996 even if higher altitudes on the island are not verified the uplands there (Pico do Castelo, Pico do Facho, Pico Juliana...) may be sufficient for there to be some differentiation in the spatial distribution of rainfall on the island of Porto Santo.

In the Canary Islands the complexity of the spatial distribution of the precipitation due to topography, with maximum precipitation occurring at intermediate altitudes, the slopes facing the north and northeast, has hampered the application of regression models with explanatory variables such as altitude. However, density of udometric posts allows for the satisfactory application of the krigagem universal with altitude as the covariate, so that the local variation of the precipitation with altitude is taken into account in the interpolation. This is different for the various dimensions of height and exposure of slopes.

For the interpolation of the average number of days of precipitation above certain thresholds $(0.1 \mathrm{~mm}, 1.0 \mathrm{~mm}, 10.0 \mathrm{~mm}$ and $30.0 \mathrm{~mm})$, due to the much lower number of observations, compared to total precipitation, it was decided to apply the local krigagem universal method, taking into account the total annual precipitation field as an auxiliary variable previously obtained at the expense of altitude.

Regarding the grids validation, and concerning the modelling difficulties of some variables, the error values obtained by cross-validation between observed and estimated values, are strongly dependent on the spatial variability of each climatic element, as well as on the climatological network density and also on the correlation with geographical factors, mainly with altitude.

\section{Projection system}

The referencing system adopted was the ITRF93 (International Terrestrial Reference Frame 1993), recommended by the Portuguese Geographic Institute (IGP) for the Azores and Madeira and the equivalent REGCAN95 Geodetic Reference System, used officially in Spain for the Canary Islands. Although the IGP suggests the application of the Universal Transverse Mercator map projection system (UTM) according to the zones of each region, it was suggested to use the UTM26N for all the islands of the Azores since the central meridian is $27^{\circ} \mathrm{W}$ and around $4^{\circ}$ from the island of Flores, the westernmost point (around $31.25^{\circ} \mathrm{W}$ ). This way no distortion is caused that prevents its use, allowing a single grid for this territory.

The respective parameters are shown below:

\section{Azores:}

ITRF93/UTM 26N

Reference ellipsoid: GRS80 (Geodetic Reference System 1980)

Cartographic projection: UTM (Universal Transverse Mercator) - zone 26

Latitude of the origin of rectangular coordinates: $0^{\circ}$

Longitude of the origin of rectangular coordinates: $27^{\circ} \mathrm{W}$

False origin of the rectangular coordinates: In E (Easting): $500000 \mathrm{~m}$ In $\mathrm{N}$ (Northing): $0 \mathrm{~m}$

Scale factor in the central meridian: 0,9996 


\section{Madeira y Canarias:}

ITRF93/UTM 28N

Elipsoide de referencia: GRS80 (Geodetic Reference System 1980)

Proyección cartográfica: UTM (Universal Transversal de Mercator) - huso 28

Latitud del origen de las coordenadas rectangulares: $0^{\circ}$

Longitud del origen de las coordenadas rectangulares: $15^{\circ} \mathrm{W}$

Falso origen de las coordenadas rectangulares: En E (Easting): $500000 \mathrm{~m}$

En $\mathrm{N}$ (Northing): $0 \mathrm{~m}$

Factor de escala en el meridiano central: 0,9996

\section{Información de base}

Se ha utilizado el Mapa Administrativo Oficial de Portugal - MAOP, versión 2011, para la cartografía de las Azores y de Madeira, que de acuerdo con metadatos del IGP "se estructuró basándose en el Catálogo de Entidades descrito de acuerdo con las normas ISO, y según un modelo de datos con entidades del tipo área y línea, con atributos armonizados de acuerdo con el proyecto EuroBoundaryMap versión 3.0 de Eurogeographics (EBM V3.0)”.

El MAOP insular está disponible en el sistema ITRF93 (International Terrestrial Reference Frame 1993) adoptado para la cartografía del Atlas.

Para la cartografía de las islas Canarias se ha utilizado la Base de Datos de Líneas Límite 1:25 000 del Instituto Geográfico Nacional Español (IGN), con la división administrativa correspondiente.

\section{Información de soporte}

La información de soporte utilizada se refiere al Modelo Digital del Terreno (MDT), que ha servido de base a todos los cálculos de regresión efectuados.

En relación al modelo digital del terreno y sus respectivos valores de altitud, se ha utilizado el SRTM (NASA Shuttle Radar Topographic Mission) de USGS (United States Geological Survey), en la versión 4 reprocesada y corregida por el CGIAR-CSI (Consortium for Spatial Information), con una resolución de 3 segundos de arco, aproximadamente 90 metros. Como el SRTM se presenta en una rejilla de latitud/ longitud, tomando como datum horizontal el WGS84 y como datum vertical el EGM96, ha sido necesario proyectarlo en el sistema de referenciación utilizado (ITRF93-UTM), habiéndose optado por una resolución final de 100 metros. Esta resolución ha sido la elegida para elaborar toda la cartografía.

\section{Madeira e Canárias:}

ITRF93/UTM 28N

Elipsoide de referência: GRS80 (Geodetic Reference System 1980)

Projeção cartográfica: UTM (Universal Transverse Mercator) - fuso 28

Latitude da origem das coordenadas retangulares: $0^{\circ}$

Longitude da origem das coordenadas retangulares: $15^{\circ} \mathrm{W}$

Falsa origem das coordenadas retangulares:

Em E (Easting): $500000 \mathrm{~m}$

Em N (Northing): $0 \mathrm{~m}$

Fator de escala no meridiano central: 0,9996

\section{Informação estruturante}

Foi utilisada a Carta Administrativa Oficial de Portugal - CAOP, versão 2011, para a cartografia dos Açores e da Madeira, que de acordo com metadata do IGP foi "estruturada tendo por base o Catálogo de Entidades descrito de acordo com as normas ISO, e segundo um modelo de dados com entidades do tipo área e linha, com atributos harmonizados de acordo com o projeto EuroBoundaryMap versão 3.0 da Eurogeographics (EBM V3.0)".

A CAOP insular é já disponibilizada no sistema ITRF93 (International Terrestrial Reference Frame 1993) adotado para a cartografia do Atlas.

Para a cartografia das ilhas Canárias, utilizou-se a Base de Dados de Linhas Limite 1:25 000 do Instituto Geográfico Nacional de Espanha (IGN), com a divisão administrativa correspondente.

\section{Informação de suporte}

A informação de suporte utilizada diz respeito ao Modelo Digital do Terreno - MDT, que serviu de base a todos os cálculos de regressão efetuados.

Relativamente ao modelo digital do terreno e respetivos valores de altitude, utilizou-se o SRTM (NASA Shuttle Radar Topographic Mission) da USGS (United States Geological Survey), na versão 4 reprocessada e corrigida pela CGIAR-CSI (Consortium for Spatial Information), com uma resolução de 3 segundos de arco, aproximadamente 90 metros. Como o SRTM é disponibilizado numa grelha de latitude/ longitude, tendo como datum horizontal o WGS84 e como datum vertical o EGM96, houve a necessidade de o projetar para o sistema de referenciação utilizado (ITRF93-UTM), tendo-se optado por uma resolucão final de 100 metros. Esta resolução foi a escolhida para a produção de toda a cartografia.
Madeira e Canárias:

ITRF93/UTM 28N

Reference ellipsoid: GRS80 (Geodetic Reference System 1980)

Cartographic projection: UTM (Universal Transverse Mercator) — zone 28

Latitude of the origin of rectangular coordinates: $0^{\circ}$

Longitude of the origin of rectangular coordinates: $15^{\circ} \mathrm{W}$

False origin of the rectangular coordinates: In E (Easting): $500000 \mathrm{~m}$

In $\mathrm{N}$ (Northing): $0 \mathrm{~m}$

Scale factor in the central meridian: 0,9996

\section{Structuring information}

The Official Administrative Letter of Portugal CAOP, version 2011, was used for the mapping of the Azores and Madeira, which according to the metadata of the IGP was "structured based on the Catalogue of Entities described in accordance with ISO standards, and in accordance with a data model with area and line entities. Said model had attributes harmonized in accordance with the design of EuroBoundaryMap version 3.0 of EuroGeographics (EBM V3.0)".

The separate CAOP is already available in the ITRF93 system (International Terrestrial Reference Frame 1993) adopted for the mapping of the Atlas.

For the mapping of the Canary Islands the 1:25000 Line Limit of the database is used, taken from the National Geographic Institute of Spain (NGI), with the corresponding administrative division.

\section{Supporting information}

The supporting information used relates to the Digital Terrain Model — DTM, which formed the basis of all regression calculations performed.

For the digital terrain model and respective values of altitude, the SRTM (NASA Shuttle Radar Topographic Mission) of the USGS (United States Geological Survey) was used, in version 4 reprocessed and corrected by the CGIAR-CSI (Consortium for Spatial Information) with a resolution of 3 arc seconds, approximately 90 meters. Since the SRTM is available on a grid of latitude/longitude, with WGS84 as the horizontal datum and EGM96 as the vertical datum, it was necessary for it to be designed for the reference system used (ITRF93-UTM), with a final resolution of 100 meters being chosen. This resolution was chosen for the production of all mapping. 


\section{Temperatura}

Se presentan los mapas de los valores medios anuales y mensuales correspondientes a las medias de los valores máximos y mínimos diarios observados de la temperatura del aire. Los números medios de días por año con temperatura máxima igual o superior a $25^{\circ} \mathrm{C}$, y con temperatura mínima igual o superior a $20^{\circ} \mathrm{C}$ e igual o inferior a $0{ }^{\circ} \mathrm{C}$ dan información sobre la frecuencia de registro de valores elevados o bajos de temperatura.

\section{Temperatura}

São apresentadas as cartas dos valores médios no ano e no mês, que correspondem às médias dos valores máximos e mínimos diários observados da temperatura do ar. Os números médios de dias no ano com temperatura máxima igual ou superior a $25^{\circ} \mathrm{C}$, e com temperatura mínima igual ou superior a $20{ }^{\circ} \mathrm{C}$ e igual ou inferior a $0{ }^{\circ} \mathrm{C}$ dá informação sobre a frequência da ocorrência de valores elevados ou baixos de temperatura.

\section{Temperature}

The average value maps are shown for the year and month, which correspond to the average values of maximum and minimum daily air temperature observed. The average number of days in the year with a maximum temperature equal to or above $25^{\circ} \mathrm{C}$ and with a minimum temperature of no less than $20^{\circ} \mathrm{C}$ and not exceeding $0^{\circ} \mathrm{C}$ offers information on the frequency of occurrence of high or low temperatures.

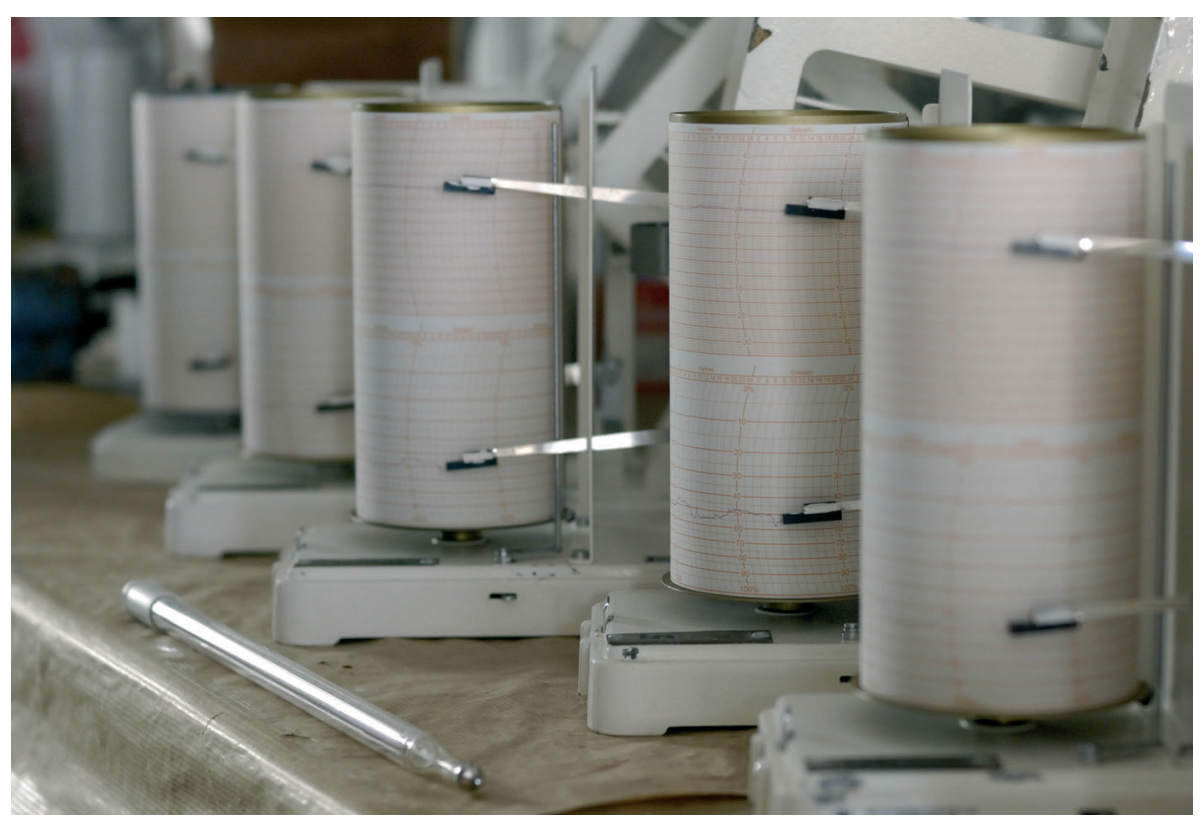

\subsection{Archipiélago de Canarias}

Los valores de la temperatura media anual del aire en el archipiélago de Canarias dependen básicamente de la orografía y varían desde $20^{\circ} \mathrm{C}-21^{\circ} \mathrm{C}$ en las áreas situadas al nivel del mar hasta llegar a valores inferiores a $4{ }^{\circ} \mathrm{C}$ en el pico del Teide en la isla de Tenerife. También se aprecian áreas con temperaturas medias anuales por debajo de los $10{ }^{\circ} \mathrm{C}$ en las zonas más elevadas de la isla de La Palma, mientras que en las islas de El Hierro, Gran Canaria y La Gomera los valores de la temperatura media anual en las zonas más elevadas del centro de las mismas se sitúan en torno a los $12{ }^{\circ} \mathrm{C}$.

Las temperaturas medias mensuales en Canarias varían de forma regular a lo largo del año, con una amplitud térmica anual del orden de los $6^{\circ} \mathrm{C}$ a $7^{\circ} \mathrm{C}$ en los observatorios situados al nivel del mar, siendo la amplitud ligeramente más elevada en las islas más orientales del archipiélago y menor en las islas más occidentales (El Hierro y La Palma). Esta amplitud térmica se incrementa con la altitud, de forma que en el observatorio de Izaña, a 2371 metros sobre el nivel del mar, alcanza un valor de $14{ }^{\circ} \mathrm{C}$.

Las temperaturas medias más elevadas en las zonas situadas a nivel del mar se registran en la segunda mitad del verano, en los meses de agosto y septiem-

\subsection{Arquipélago das Canárias}

Os valores da temperatura média do ar anual no arquipélago das Canárias dependem basicamente da orografia e variam desde $20^{\circ} \mathrm{C}-21{ }^{\circ} \mathrm{C}$, nas áreas situadas ao nível do mar até valores inferiores a $4{ }^{\circ} \mathrm{C}$ no Pico de Teide na ilha de Tenerife. Também se encontram áreas com temperaturas médias anuais inferiores a $10{ }^{\circ} \mathrm{C}$ em zonas mais elevadas da ilha de Palma, ao passo que nas ilhas de Hierro, Gran Canária e La Gomera os valores da temperatura média anual ocorrem nas zonas mais elevadas do interior das mesmas, próximos de $12^{\circ} \mathrm{C}$.

As temperaturas médias mensais nas Canárias variam de forma regular ao longo do ano, com uma amplitude térmica anual da ordem de $6{ }^{\circ} \mathrm{C}$ a $7{ }^{\circ} \mathrm{C}$ nas estações meteorológicas situadas ao nível do mar, sendo a amplitude ligeiramente mais elevada nas ilhas mais orientais do arquipélago e menor nas ocidentais (em Hierro e La Palma). Esta amplitude térmica aumenta com a altitude, sendo que na estação meteorológica de Izaña, a 2371 metros sobre o nível do mar, regista-se um valor de $14{ }^{\circ} \mathrm{C}$.

As temperaturas médias mais elevadas situadas ao nível do mar, ocorrem nos meses de agosto e setembro, com valores de cerca de $24{ }^{\circ} \mathrm{C}$. Nas ilhas

\subsection{Archipelago of the Canary Islands}

The values of annual average air temperature in the archipelago of the Canary Islands basically depends on the terrain and varies between $20^{\circ} \mathrm{C}$ and $21^{\circ} \mathrm{C}$, for the areas located at sea level; while values below $4{ }^{\circ} \mathrm{C}$ are found on the "Pico de Teide" on the island of Tenerife. Areas with annual average temperatures below $10^{\circ} \mathrm{C}$ in higher areas of the island of Palma were also found, while on the islands of $\mathrm{El}$ Hierro, in Gran Canaria and La Gomera, the average annual temperature values occur in the higher areas of the interior of the islands, around $12{ }^{\circ} \mathrm{C}$.

The monthly average temperatures in the Canary Islands vary on a regular basis throughout the year, with an annual temperature range of about $6{ }^{\circ} \mathrm{C}$ to $7^{\circ} \mathrm{C}$ in the meteorological stations located at sea level. The magnitude is slightly higher on the most easterly island of the archipelago and the smaller island on the west of the archipelago (El Hierro and $\mathrm{La} \mathrm{Pal-}$ ma). This temperature range increases with altitude, with the meteorological station at Izaña, some 2371 meters above sea level, registering a value of $14^{\circ} \mathrm{C}$.

The higher average temperatures located at sea level are recorded in August and September, with values of around $24^{\circ} \mathrm{C}$. In the most easterly islands 
bre, con valores en torno a $24^{\circ} \mathrm{C}$. En las islas más orientales estos valores son ligeramente más altos que en las occidentales. En las zonas elevadas el máximo anual de temperaturas se produce en los meses de julio y agosto. Las temperaturas medias mensuales más bajas se registran en todas las zonas del archipiélago en los meses de enero y febrero, con temperaturas medias a nivel del mar de $17^{\circ} \mathrm{C}$ a $18^{\circ} \mathrm{C}$, valores que son ligeramente más bajos en las islas de Lanzarote y Fuerteventura. En las zonas más altas de la isla de Tenerife las temperaturas medias mensuales del mes de enero están por debajo de $-2{ }^{\circ} \mathrm{C}$.

Los valores medios anuales de las temperaturas máximas diarias en Canarias varían desde $24^{\circ} \mathrm{C}$ en las zonas costeras hasta valores por debajo de $10^{\circ} \mathrm{C}$ en la cima del Teide. En los meses de verano los valores medios de temperatura máxima diaria alcanzan los $28{ }^{\circ} \mathrm{C}$ en las zonas costeras de Lanzarote y Fuerteventura y en las costas de las islas de Tenerife y Gran Canaria no orientadas al norte, mientras que en el resto de las áreas a nivel del mar se sitúan en torno a $26^{\circ} \mathrm{C}$. Los valores medios anuales de las temperaturas máximas diarias más bajos en los meses de verano se producen en la cima del Teide donde no alcanzan los $20^{\circ} \mathrm{C}$. En los meses de invierno las temperaturas máximas medias alcanzan los $22^{\circ} \mathrm{C}$ en el sur de la isla de Tenerife, mientras en el resto de las zonas costeras son del orden de $20^{\circ} \mathrm{C}$. En los puntos más altos del macizo del Teide estos valores están por debajo de los $2{ }^{\circ} \mathrm{C}$.

La media anual de las temperaturas mínimas diarias en Canarias registra valores en torno a $18^{\circ} \mathrm{C}$ en zonas costeras, situándose ligeramente por debajo de este valor en las islas orientales de Fuerteventura y Lanzarote. En el pico del Teide son inferiores a los $-2^{\circ} \mathrm{C}$. En los meses más cálidos de verano (agosto y septiembre) los valores medios de temperatura mínima diaria alcanzan los $20^{\circ} \mathrm{C}-21^{\circ} \mathrm{C}$ a nivel del mar, disminuyendo con la altura y llegando en la cima del Teide a valores por debajo de $6{ }^{\circ} \mathrm{C}$. En los meses invernales las temperaturas mínimas medias diarias son del orden de $14^{\circ} \mathrm{C}$ en las áreas costeras de las islas de Fuerteventura y Lanzarote y de $15{ }^{\circ} \mathrm{C}$ en el resto de las islas del archipiélago, mientras en la cima del Teide alcanza valores por debajo de los $-6^{\circ} \mathrm{C}$.

En el archipiélago canario las heladas solo se observan en zonas con altitud superior a 1000 metros sobre el nivel del mar. Los valores más altos del número anual de días con temperatura mínima inferior o igual a $0{ }^{\circ} \mathrm{C}$ se producen en las cumbres del macizo del Teide donde se superan los 100 días. Por otro lado, el número anual de días con temperatura mínima igual o superior a $20^{\circ} \mathrm{C}$ presenta valores máximos superiores a 120 días en las áreas costeras mientras que en las zonas más altas de las islas de Gran Canaria, La Palma, El Hierro y La Gomera, así como en todo el macizo del Teide este número es inferior a 1. El número de días con valores de temperatura máxima superiores o iguales a $25{ }^{\circ} \mathrm{C}$ supera el valor de 150 en áreas costeras de Lanzarote y algunas zonas a nivel del mar de Tenerife y Gran Canaria. Este valor disminuye con la altitud siendo inferior a 1 día en las zonas más altas de La Palma $y$ en el macizo del Teide.

\subsection{Archipiélagos de Madeira y Azores}

Los valores medios anuales de la temperatura media del aire en las Azores y en Madeira dependen claramente de la altitud del lugar y disminuyen a medida que aumenta la altitud. De este modo, los valores medios oscilan de $14^{\circ} \mathrm{C}$ a $18^{\circ} \mathrm{C}$ en las regiones costeras y de $6{ }^{\circ} \mathrm{C}$ a $12{ }^{\circ} \mathrm{C}$ en las áreas de mayor altitud, excepto en el punto más alto de la isla de Pico (montaña del Pico) donde la temperatura es inferior a $2{ }^{\circ} \mathrm{C}$. mais orientais estes valores são ligeiramente mais elevados do que nas ocidentais. Em cotas mais elevadas, o máximo anual das temperaturas ocorre nos meses de julho e de agosto. As temperaturas médias mensais mais baixas registam-se em todas as zonas do arquipélago, nos meses de janeiro e fevereiro, com temperaturas médias ao nível do mar de $17{ }^{\circ} \mathrm{C}$ a $18{ }^{\circ} \mathrm{C}$, valores que são ligeiramente mais baixos nas ilhas de Lanzarote e Fuerteventura. Nas cotas mais elevadas da ilha de Tenerife as temperaturas médias mensais do mês de janeiro são inferiores a $-2,0{ }^{\circ} \mathrm{C}$.

Os valores médios anuais das temperaturas máximas diárias nas Canárias variam entre $24{ }^{\circ} \mathrm{C}$ nas zonas costeiras até valores inferiores a $10{ }^{\circ} \mathrm{C}$ no Pico de Teide. Em todos os meses de verão os valores médios da temperatura máxima diária alcançam $28{ }^{\circ} \mathrm{C}$ em zonas costeiras de Lanzarote e Fuerteventura e nas costas das ilhas de Tenerife e Gran Canária não orientadas a Norte, enquanto que o resto das áreas ao nível do mar se situam com valores de cerca de $26^{\circ} \mathrm{C}$. Os valores médios anuais das temperaturas máximas diárias mais baixos nos meses de verão, ocorrem no Pico de Teide onde alcançam os $20{ }^{\circ} \mathrm{C}$. Nos meses de inverno, a média das temperaturas máximas é de $22{ }^{\circ} \mathrm{C}$ ao sul da ilha de Tenerife, enquanto que nas restantes zonas costeiras são da ordem de $20{ }^{\circ} \mathrm{C}$. Nos pontos mais elevados do maciço de Teide estes valores são inferiores a $2{ }^{\circ} \mathrm{C}$.

A média anual da temperatura mínima diária nas Canárias regista valores próximo dos $18{ }^{\circ} \mathrm{C}$ em zonas costeiras, situando-se ligeiramente abaixo deste valor nas ilhas orientais de Fuerteventura e Lanzarote. No Pico de Teide são inferiores a $-2{ }^{\circ} \mathrm{C}$. Nos meses mais quentes (agosto e setembro) os valores médios da temperatura mínima diária alcançam $20{ }^{\circ} \mathrm{C}-21{ }^{\circ} \mathrm{C}$ ao nível do mar, diminuindo com a altitude e alcançando no Pico de Teide valores inferiores a $6{ }^{\circ} \mathrm{C}$. Nos meses invernais a média da temperatura mínima diária é da ordem de $14{ }^{\circ} \mathrm{C}$ em áreas costeiras das ilhas de Fuerteventura e Lanzarote e de $15{ }^{\circ} \mathrm{C}$ no resto das ilhas do arquipélago, enquanto que no Pico de Teide os valores podem ser inferiores a $-6{ }^{\circ} \mathrm{C}$.

No arquipélago das Canárias, o número de dias com temperatura mínima do ar inferior ou igual a $0{ }^{\circ} \mathrm{C}$, observam-se em altitudes superiores a 1000 metros. Os valores mais elevados do número anual de dias com temperatura mínima do ar inferior ou igual a $0{ }^{\circ} \mathrm{C}$, ocorrem no maciço de Teide, onde superam os 100 dias. Por outro lado, o número anual de dias com temperatura mínima superior ou igual a $20{ }^{\circ} \mathrm{C}$ apresenta valores máximos superiores a 120 dias em áreas costeiras, enquanto que nas zonas de maior altitude das ilhas de Gran Canária, La Palma, Hierro e La Gomera, assim como no maciço de Teide este número é inferior a 1 dia. O número de dias com valores de temperatura máxima do ar superior ou igual a $25^{\circ} \mathrm{C}$ supera os 150 dias em áreas costeiras de Lanzarote e algumas zonas ao nivel do mar de Tenerife e Gran Canária. Este valor diminui com a latitude sendo inferior a 1 dia nas zonas mais elevadas de La Palma e no maciço de Teide.

\subsection{Arquipélagos da Madeira e dos Açores}

Os valores médios anuais da temperatura média do ar nos arquipélagos dos Açores e da Madeira dependem nitidamente da altitude do local e diminuem quando a altitude aumenta. Assim, os valores médios variam entre $14{ }^{\circ} \mathrm{C}$ e $18{ }^{\circ} \mathrm{C}$ nas regiões costeiras e entre $6{ }^{\circ} \mathrm{C}$ e $12^{\circ} \mathrm{C}$ nas áreas de maior altitude, exceto no ponto mais alto da ilha do Pico (montanha do Pico) onde a temperatura é inferior a $2{ }^{\circ} \mathrm{C}$. these values are slightly higher than in the more westerly islands. In higher altitudes, the maximum annual temperatures occur in July and August. The lowest average monthly temperatures are recorded in all areas of the archipelago in the months of January and February with temperatures at sea level of between $17^{\circ} \mathrm{C}$ and $18^{\circ} \mathrm{C}$. These values are slightly lower on the islands of Lanzarote and Fuerteventura. At higher altitudes of the island of Tenerife the monthly average temperatures for January are below $-2.0^{\circ} \mathrm{C}$.

The annual average maximum temperatures in the Canary Islands range from $24^{\circ} \mathrm{C}$ in coastal areas to values below $10^{\circ} \mathrm{C}$ in the Pico de Teide. In all summer months the maximum average daily temperature reaches $28{ }^{\circ} \mathrm{C}$ in coastal areas of Lanzarote and Fuerteventura and those coastal areas of the islands of Tenerife and Gran Canaria which are not north-facing, while the rest of the areas at sea level have values of around $26^{\circ} \mathrm{C}$. The lowest annual average of maximum temperatures in the summer months, occur on Pico de Teide where they reach $20{ }^{\circ} \mathrm{C}$. In the winter months, the average maximum temperature is $22^{\circ} \mathrm{C}$ in the south of Tenerife, while in other coastal areas they are around $20^{\circ} \mathrm{C}$. At the highest points of the mountain of Mount Teide the values fall below $2{ }^{\circ} \mathrm{C}$.

The annual average daily minimum temperature in the Canary Islands is recorded with values close to $18{ }^{\circ} \mathrm{C}$ in coastal areas, and at slightly below this value in the eastern islands of Fuerteventura and Lanzarote. On the Pico de Teide the value is below $-2{ }^{\circ} \mathrm{C}$. In the warmer months (between August and September) the average minimum daily temperature reaches between $20^{\circ} \mathrm{C}$ and $21^{\circ} \mathrm{C}$ at sea level, decreasing with altitude and reaching values below $6{ }^{\circ} \mathrm{C}$ on Pico de Teide. In winter months the average daily minimum temperature is around $14{ }^{\circ} \mathrm{C}$ in coastal areas of the islands of Fuerteventura and Lanzarote and $15{ }^{\circ} \mathrm{C}$ in the rest of the islands of the archipelago, while in the Pico de Teide values may be lower than $-6{ }^{\circ} \mathrm{C}$.

In the Canaries the number of days with a minimum air temperature of less than or equal to $0{ }^{\circ} \mathrm{C}$ can be observed at altitudes above 1000 meters. The highest values of the annual number of days with a minimum temperature less than or equal to $0^{\circ} \mathrm{C}$ occur on the mountain of Mount Teide, which exceed 100 days. On the other hand, the annual number of days with minimum temperatures greater than or equal to $20^{\circ} \mathrm{C}$ shows maximum values in excess of 120 days in coastal areas, while in the more elevated areas of the islands of Gran Canaria, La Palma, El Hierro and La Gomera, as well as in the mountain of Mount Teide, this number is less than 1 day. The number of days with values of maximum air temperature greater than or equal to $25^{\circ} \mathrm{C}$ exceeds 150 days in coastal areas of Lanzarote and some areas at sea level of Tenerife and Gran Canaria. This value decreases with latitude and is less than 1day in higher areas of La Palma and Mount Teide.

\subsection{Archipelagos of Madeira and the Azores}

The average annual air temperature in the archipelago of the Azores and Madeira depends markedly on the altitude of the area in question and decreases when the altitude increases. Thus the average values vary between $14^{\circ} \mathrm{C}$ and $18{ }^{\circ} \mathrm{C}$ in coastal areas and between $6{ }^{\circ} \mathrm{C}$ and $12{ }^{\circ} \mathrm{C}$ in the areas of higher altitude, except at the highest point of the island of Pico (Pico Mountain) where the temperature is below $2{ }^{\circ} \mathrm{C}$. 
Los valores de la temperatura media mensual varían regularmente durante el año, alcanzando los valores máximos en verano, sobre todo en el mes de agosto, y los valores mínimos en invierno, principalmente en los meses de enero y febrero.

Los valores medios mensuales más bajos de la temperatura media del aire en enero y en febrero se registran en las áreas de mayor altitud de las Azores y de Madeira y varían entre $4{ }^{\circ} \mathrm{C}$ y $8{ }^{\circ} \mathrm{C}$, excepto en la montaña del Pico (Ponta do Pico) donde se observan valores todavía más bajos, inferiores a $0{ }^{\circ} \mathrm{C}$. En el mes más cálido, agosto, los valores más altos en el archipiélago de las Azores, cercanos a los $22^{\circ} \mathrm{C}$, se registran en algunas áreas costeras de todas las islas, pero en concreto en Santa María (área oeste), en São Miguel (área sur), en Corvo, en Pico y en Faial (área sudeste). En Madeira los valores más elevados (superiores a $22^{\circ} \mathrm{C}$ ) se registran en las áreas costeras de la isla de Madeira y en casi toda la isla de Porto Santo.

Los valores medios anuales de la temperatura máxima del aire en las Azores y en Madeira varían entre $12{ }^{\circ} \mathrm{C}$ y $14^{\circ} \mathrm{C}$ en las áreas de altitudes más elevadas, siendo incluso inferior a $8{ }^{\circ} \mathrm{C}$ en Ponta do Pico —en la isla de Pico- en las Azores. Los valores más elevados de la temperatura máxima del aire en las Azores, superiores a $20^{\circ} \mathrm{C}$, se registran en algunas áreas costeras de las islas de São Miguel, de Santa María, de Terceira, de Graciosa y de Pico. En Madeira, los valores medios más elevados de la temperatura máxima del aire también superan los $20^{\circ} \mathrm{C}$ en las regiones costeras de la isla de Madeira y en casi toda la isla de Porto Santo, superando incluso los $22^{\circ} \mathrm{C}$ en la franja litoral sur y noroeste de la isla de Madeira.

En verano los valores medios de la temperatura máxima del aire en las Azores varían entre $18^{\circ} \mathrm{C}$ en las regiones de mayor altitud y $24^{\circ} \mathrm{C}$ en las regiones de menor altitud. El mes de agosto presenta los valores medios más elevados, entre $24{ }^{\circ} \mathrm{C}$ y $26{ }^{\circ} \mathrm{C}$ en las regiones costeras.

En el archipiélago de Madeira los valores de la temperatura máxima del aire en verano varían entre los $17{ }^{\circ} \mathrm{C}$ (en la región de Pico do Arieiro) y $26^{\circ} \mathrm{C}$ en las áreas costeras de Madeira y en Porto Santo. También en Madeira el mes de agosto presenta los valores medios más elevados, entre $18^{\circ} \mathrm{C}$ en el Pico do Areeiro y $28^{\circ} \mathrm{C}$ en una pequeña franja litoral de la vertiente sur de la isla de Madeira.

Los valores más bajos de la temperatura máxima se registran en invierno (inferiores a $12{ }^{\circ} \mathrm{C}$ ) en las regiones de mayor altitud de las islas de São Miguel, de Terceira, de São Jorge, de Pico y de Faial en las Azores y en la isla de Madeira. Los valores mínimos de la temperatura máxima del aire se registran en los meses de enero y de febrero y tienen lugar en Ponta do Pico en las Azores, inferiores a $0^{\circ} \mathrm{C}$, y en el Pico do Arieiro y en Bica da Cana en Madeira, inferiores a $8{ }^{\circ} \mathrm{C}$.

Los valores medios anuales de la temperatura mínima del aire en las Azores y en Madeira varían entre $4^{\circ} \mathrm{C}$ y $8^{\circ} \mathrm{C}$ en las áreas de mayor altitud, siendo incluso inferiores a $0^{\circ} \mathrm{C}$ en la montaña del Pico y valores superiores a $12{ }^{\circ} \mathrm{C}$ en las zonas costeras.

Los valores medios mensuales más bajos de la temperatura mínima del aire (inferiores a $8^{\circ} \mathrm{C}$ ) se registran en los meses de diciembre a febrero (período de invierno) en las áreas de mayor altitud y los valores más altos (superiores a $16{ }^{\circ} \mathrm{C}$ ) se registran en los meses de julio y de agosto, en las zonas costeras de la isla de Madeira y en toda la isla de Porto Santo y en las Azores en las islas de Santa María, Corvo y de Graciosa y también en las zonas costeras de las islas de São Miguel, Terceira, São Jorge, Pico, Faial y Flores.

El número de días por año con temperatura mínima inferior o igual a $0^{\circ} \mathrm{C}$, en el archipiélago de las
Os valores da temperatura média mensal variam regularmente durante o ano, atingindo os valores máximos no verão nomeadamente no mês de agosto e os valores mínimos no inverno, nomeadamente nos meses de janeiro e de fevereiro.

Os valores médios mensais mais baixos da temperatura média do ar em janeiro e em fevereiro, ocorrem nas áreas de maior altitude dos Arquipélagos dos Açores e da Madeira e variam entre $4{ }^{\circ} \mathrm{C}$ e $8{ }^{\circ} \mathrm{C}$, exceto na montanha do Pico (Ponta do Pico) onde se observam valores ainda mais baixos, inferiores a $0{ }^{\circ} \mathrm{C}$. No mês mais quente, agosto, os valores mais altos no arquipélago dos Açores, próximos dos $22{ }^{\circ} \mathrm{C}$, ocorrem nalgumas áreas costeiras de todas as ilhas, mas em particular em Santa Maria (área oeste), em São Miguel (área Sul), no Corvo, no Pico e no Faial (área sueste). $\mathrm{Na}$ Madeira os valores mais elevados (superiores a $22{ }^{\circ} \mathrm{C}$ ) ocorrem nas áreas costeiras da ilha da Madeira e em quase toda a ilha de Porto Santo.

Os valores médios anuais da temperatura máxima do ar nos arquipélagos dos Açores e da Madeira variam entre $12{ }^{\circ} \mathrm{C}$ a $14{ }^{\circ} \mathrm{C}$ nas áreas de altitudes mais elevadas, sendo mesmo inferior a $8{ }^{\circ} \mathrm{C}$ na Ponta do Pico na ilha do Pico nos Açores. Os valores mais elevados da temperatura máxima do ar nos Açores, superiores a $20{ }^{\circ} \mathrm{C}$, ocorrem em algumas áreas costeiras das ilhas de São Miguel, de Santa Maria, da Terceira, da Graciosa e do Pico. Na Madeira, os valores médios mais elevados da temperatura máxima do ar, também são superiores a $20{ }^{\circ} \mathrm{C}$ nas regiões costeiras da ilha da Madeira e em quase toda a ilha de Porto Santo, sendo mesmo superior a $22{ }^{\circ} \mathrm{C}$ na faixa litoral Sul e Noroeste da ilha da Madeira.

No verão os valores médios da temperatura máxima do ar nos Açores variam entre $18{ }^{\circ} \mathrm{C}$ nas regiões de maior altitude e $24{ }^{\circ} \mathrm{C}$ nas regiões de menor altitude. $\mathrm{O}$ mês de agosto apresenta os maiores valores médios, entre $24{ }^{\circ} \mathrm{C}$ e $26{ }^{\circ} \mathrm{C}$ nas regiões costeiras.

No arquipélago da Madeira os valores da temperatura máxima do ar no verão têm uma variação entre $17{ }^{\circ} \mathrm{C}$ (na região do Pico do Arieiro) e $26{ }^{\circ} \mathrm{C}$ nas áreas costeiras da Madeira e em Porto Santo. Também na Madeira o mês de agosto é o que apresenta os maiores valores médios, entre $18^{\circ} \mathrm{C}$ no Pico do Areeiro e $28{ }^{\circ} \mathrm{C}$ numa pequena faixa litoral da vertente sul da ilha da Madeira.

Os valores mais baixos da temperatura máxima ocorrem no inverno (inferiores a $12{ }^{\circ} \mathrm{C}$ ) nas regiões de maior altitude das ilhas de São Miguel, da Terceira, de São Jorge, do Pico e do Faial nos Açores e na ilha da Madeira. Os valores mínimos da temperatura máxima do ar, ocorrem nos meses de janeiro e de fevereiro e verificam-se na Ponta do Pico nos Açores, inferiores a $0{ }^{\circ} \mathrm{C}$ e no Pico do Arieiro e em Bica da Cana na Madeira, inferiores a $8{ }^{\circ} \mathrm{C}$.

Os valores médios anuais da temperatura mínima do ar nos Açores e na Madeira variam entre $4{ }^{\circ} \mathrm{C}$ a $8{ }^{\circ} \mathrm{C}$ nas áreas de maior altitude, sendo mesmo inferiores a $0{ }^{\circ} \mathrm{C}$ na montanha do Pico e, valores superiores a $12{ }^{\circ} \mathrm{C}$ nas zonas costeiras.

Os valores médios mensais mais baixos da temperatura mínima do ar (inferiores a $8{ }^{\circ} \mathrm{C}$ ), ocorrem nos meses de dezembro a fevereiro (período do inverno) nas áreas de maior altitude e os valores mais altos (superiores a $16{ }^{\circ} \mathrm{C}$ ) ocorrem nos meses de julho e de agosto, nas zonas costeiras da ilha da Madeira e em toda a ilha de Porto Santo e nos Açores nas ilha de Santa Maria, do Corvo e da Graciosa e também nas zonas costeiras das ilhas de São Miguel, Terceira, São Jorge, Pico, Faial e Flores.

O número de dias no ano com temperatura mínima inferior ou igual a $0{ }^{\circ} \mathrm{C}$, no arquipélago dos
The average monthly temperature value varies regularly throughout the year, reaching maximum values in summer months, especially in August, and minimum values in winter, in the months of January and February.

The lowest monthly average air temperature in January and February occurs in areas of higher altitude of the Azores and Madeira and varies between $4{ }^{\circ} \mathrm{C}$ and $8{ }^{\circ} \mathrm{C}$, except in Pico (Ponta do Pico) where even lower values are observed, below $0{ }^{\circ} \mathrm{C}$. In the hottest month, August, the highest values in the archipelago of the Azores, close to $22^{\circ} \mathrm{C}$, occur in some coastal areas of all the islands, but particularly in Santa Maria (western area) in São Miguel (southern area), in Corvo, Pico and Faial (south-eastern area). In Madeira, the highest values (above $22^{\circ} \mathrm{C}$ ) occur in coastal areas of the island of Madeira and in almost the entire island of Porto Santo.

The annual average maximum air temperature in the Azores and Madeira is between $12^{\circ} \mathrm{C}$ and $14^{\circ} \mathrm{C}$ in the areas of higher altitudes, and below $8{ }^{\circ} \mathrm{C}$ in Ponta do Pico on Pico Island in the Azores. The highest maximum air temperature values in the Azores, above $20^{\circ} \mathrm{C}$, occur in some coastal areas of the islands of São Miguel, Santa Maria, Terceira, Graciosa and Pico. In Madeira, the highest average maximum air temperature values are also above $20^{\circ} \mathrm{C}$ in coastal regions of Madeira and in almost the entire island of Porto Santo, where values are even higher than $22^{\circ} \mathrm{C}$ in the southern and north-western coastal strip of the island of Madeira.

In summer the average maximum air temperature in the Azores varies between $18^{\circ} \mathrm{C}$ in regions of higher altitude and $24^{\circ} \mathrm{C}$ in the lower regions. The month of August has the highest average, between $24{ }^{\circ} \mathrm{C}$ and $26{ }^{\circ} \mathrm{C}$ in coastal regions.

In the archipelago of Madeira the maximum air temperature values in summer have a range of between $17{ }^{\circ} \mathrm{C}$ (in the region of Pico do Arieiro) and $26^{\circ} \mathrm{C}$ in coastal areas of Madeira and Porto Santo. Moreover, in Madeira, the month of August has the highest average value; between $18^{\circ} \mathrm{C}$ in Pico Areeiro and $28^{\circ} \mathrm{C}$ in a small coastal strip of the southern slope of Madeira.

The lowest maximum temperature occurs in the winter (below $12^{\circ} \mathrm{C}$ ) in the higher altitudes of the islands of São Miguel, Terceira, São Jorge, Pico and Faial in the Azores and Madeira. The minimum values of maximum air temperature occur in January and February and are recorded at Ponta do Pico in the Azores, below $0{ }^{\circ} \mathrm{C}$ and Pico Arieiro and Bica da Cana in Madeira, below $8^{\circ} \mathrm{C}$.

The average annual minimum temperature in the Azores and Madeira ranges between $4{ }^{\circ} \mathrm{C}$ and $8{ }^{\circ} \mathrm{C}$ in areas of higher altitude, and drops below $0{ }^{\circ} \mathrm{C}$ in Mount Pico, with values above $12^{\circ} \mathrm{C}$ in coastal areas.

The lowest monthly average values of the minimum air temperature (below $8^{\circ} \mathrm{C}$ ) occur in the months from December to February (winter period) in the areas of higher altitude and the higher values (above $16^{\circ} \mathrm{C}$ ) occur in the months of July and August in coastal regions of Madeira and throughout the island of Porto Santo and in the Azores on the islands of Santa Maria, Graciosa and Corvo, as well as in coastal areas of the islands of São Miguel, Terceira, São Jorge, Pico, Faial and Flores.

The number of days in the year with a minimum temperature less than or equal to $0{ }^{\circ} \mathrm{C}$, in the 
Azores solamente no es nulo en la montaña del Pico, en las restantes islas no tienen relevancia temperaturas mínimas inferiores a $0{ }^{\circ} \mathrm{C}$. En el archipiélago de Madeira el número de días por año con temperatura mínima inferior o igual a $0{ }^{\circ} \mathrm{C}$ presenta valores máximos en las regiones de mayor altitud, superior a 20 días.

En los archipiélagos de las Azores y de Madeira el número de días por año con temperatura mínima superior o igual a $20^{\circ} \mathrm{C}$ presenta máximos en todas las regiones costeras, del orden de 20 días.

En cuanto al número de días por año con temperatura máxima superior o igual a $25^{\circ} \mathrm{C}$, es superior a 40 días en gran parte de las zonas costeras del archipiélago de las Azores y en las áreas sur y oeste de la isla de Madeira. nos Açores só não é nulo na montanha do Pico, nas restantes ilhas não têm relevância temperaturas mínimas inferiores a $0{ }^{\circ} \mathrm{C}$. No arquipélago da Madeira o número de dias no ano com temperatura mínima inferior ou igual a $0{ }^{\circ} \mathrm{C}$ apresenta valores máximos nas regiões de maior altitude, superiores a 20 dias.

Nos arquipélagos dos Açores e da Madeira o número de dias no ano com temperatura mínima superior ou igual a $20{ }^{\circ} \mathrm{C}$ apresenta máximos em todas as regiões costeiras, da ordem de 20 dias.

Quanto ao número de dias no ano com temperatura máxima superior ou igual a $25^{\circ} \mathrm{C}$, é superior a 40 dias em grande parte das zonas costeiras do arquipélago dos Açores e nas áreas sul e oeste da ilha da Madeira. archipelago of the Azores is only zero in Mount Pico, the other islands do not have relevant minimum temperatures below $0{ }^{\circ} \mathrm{C}$. On the Madeira Islands the number of days in the year with minimum temperatures less than or equal to $0{ }^{\circ} \mathrm{C}$ shows maximum values at higher altitudes in excess of 20 days.

In the Azores and Madeira the number of days in the year with a minimum temperature greater than or equal to $20^{\circ} \mathrm{C}$, showing maximum values in all coastal regions, is in the order of around 20 days.

Regarding the number of days in the year with a maximum temperature greater than or equal to $25^{\circ} \mathrm{C}$, this is greater than 40 days in most coastal areas in the Azores and in areas south and west of the Island of Madeira. 
Valores medios más altos mensuales y extremos de temperatura máxima y mínima del aire en el período 1971-2000

Maiores valores médios mensais e extremos da temperatura máxima e mínima do ar no período 1971-2000

Highest average monthly values and extreme maximum and minimum air temperature values for the period 1971-2000

\begin{tabular}{|c|c|c|c|c|}
\hline \multicolumn{5}{|c|}{$\begin{array}{l}\text { VALORES MEDIOS ANUALES DE LA TEMPERATURA MEDIA DEL AIRE } \\
\text { VALORES MÉDIOS ANUAIS DA TEMPERATURA MÉDIA DO AR } \\
\text { ANNUAL AVERAGE VALUES FOR MEAN AIR TEMPERATURE }\end{array}$} \\
\hline \multirow{2}{*}{$\begin{array}{l}\text { Archipiélago } \\
\text { Arquipélago } \\
\text { Archipelago }\end{array}$} & \multirow{2}{*}{$\begin{array}{l}\text { Lugar } \\
\text { Local } \\
\text { Location }\end{array}$} & \multirow{2}{*}{$\begin{array}{c}\begin{array}{c}\text { Media anual } \\
\text { Média anual } \\
\text { Annual average }\end{array} \\
\left({ }^{\circ} \mathrm{C}\right)\end{array}$} & \multicolumn{2}{|c|}{$\begin{array}{l}\text { Media más alta } \\
\text { Maior média } \\
\text { Highest average }\end{array}$} \\
\hline & & & $\left({ }^{\circ} \mathrm{C}\right)$ & Año/Ano/Year \\
\hline \multirow{5}{*}{ CANARIAS } & Santa Cruz de Tenerife/Tenerife & 21,2 & 22,7 & 1998 \\
\hline & Gando/Gran Canaria & 20,7 & 22,3 & 1998 \\
\hline & $\left.\right|_{\text {Lanzarote} / \text { Aeropuerto }^{1}}$ & 20,7 & 22,0 & 1997 \\
\hline & Fuerteventura/Aeropuerto & 20,4 & 21,6 & 1990 \\
\hline & El Hierro/Aeropuerto ${ }^{1}$ & 20,4 & 21,8 & 1997 \\
\hline \multirow{5}{*}{ MADEIRA } & Lugar de Baixo & 19,7 & 20,8 & 1998,1999 \\
\hline & Funchal/Observatório & 19,0 & 20,2 & 1995 \\
\hline & Santa Catarina/Aeroporto & 18,9 & 20,0 & 1995 \\
\hline & Porto Santo/Aeroporto & 18,6 & 19,6 & 1995 \\
\hline & Ponta Delgada/Madeira $^{2}$ & 17,8 & 18,9 & 1987 \\
\hline \multirow{5}{*}{ AÇORES } & Horta/Aeroporto ${ }^{3}$ & 17,6 & 18,1 & 1992 \\
\hline & Santa Maria/Aeroporto ${ }^{3}$ & 17,6 & 18,1 & 1991, 1992 \\
\hline & $\begin{array}{l}\text { Ponta Delgada/Observatório Afonso } \\
\text { Chaves/São Miguel }\end{array}$ & 17,5 & 18,4 & 1995 \\
\hline & Santa Cruz/Graciosa ${ }^{4}$ & 17,4 & 18,4 & 1999 \\
\hline & Madalena/Aeródromo/Pico ${ }^{5}$ & 17,4 & 17,8 & 1991 \\
\hline
\end{tabular}

\begin{tabular}{|c|c|c|c|c|}
\hline \multicolumn{5}{|c|}{$\begin{array}{l}\text { VALORES MEDIOS ANUALES MÁS ELEVADOS DE LA TEMPERATURA MÁXIMA DEL AIRE } \\
\text { MAIORES VALORES MÉDIOS ANUAIS DA TEMPERATURA MÁXIMA DO AR } \\
\text { HIGHEST ANNUAL AVERAGE VALUES FOR MAXIMUM AIR TEMPERATURE }\end{array}$} \\
\hline \multirow{2}{*}{$\begin{array}{l}\text { Archipiélago } \\
\text { Arquipélago } \\
\text { Archipelago }\end{array}$} & \multirow{2}{*}{$\begin{array}{l}\text { Lugar } \\
\text { Local } \\
\text { Location }\end{array}$} & \multirow{2}{*}{$\begin{array}{c}\begin{array}{c}\text { Media anual } \\
\text { Média anual } \\
\text { Annual average }\end{array} \\
\left({ }^{\circ} \mathrm{C}\right)\end{array}$} & \multicolumn{2}{|c|}{$\begin{array}{l}\text { Media más alta } \\
\text { Maior média } \\
\text { Highest average }\end{array}$} \\
\hline & & & $\left({ }^{\circ} \mathrm{C}\right)$ & Año/Ano/Year \\
\hline \multirow{5}{*}{ CANARIAS } & Lanzarote/Aeropuerto $^{1}$ & 24,5 & 25,8 & 1997 \\
\hline & Santa Cruz de Tenerife/Tenerife & 24,3 & 25,8 & 1998 \\
\hline & Gando/Gran Canaria & 23,8 & 25,4 & 1998 \\
\hline & Fuerteventura/Aeropuerto & 23,7 & 25,2 & 1990 \\
\hline & El Hierro/Aeropuerto ${ }^{1}$ & 23,0 & 24,1 & 1987 \\
\hline \multirow{5}{*}{ MADEIRA } & Lugar de Baixo & 23,3 & 24,8 & 1995 \\
\hline & Funchal/Observatório & 22,1 & 23,1 & 1995 \\
\hline & Santa Catarina/Aeroporto & 21,5 & 22,6 & 1995 \\
\hline & Porto Santo/Aeroporto & 21,1 & 22,2 & 1995 \\
\hline & Ponta Delgada/Madeira ${ }^{2}$ & 20,8 & 22,0 & 1987 \\
\hline \multirow{5}{*}{ AÇORES } & $\begin{array}{l}\text { Ponta Delgada/Observatório Afonso } \\
\text { Chaves/São Miguel }\end{array}$ & 20,4 & 21,2 & 1995 \\
\hline & Santa Maria/Aeroporto ${ }^{3}$ & 20,3 & 20,9 & 1980 \\
\hline & Lajes/Aeroporto/Terceira & 20,2 & 21,5 & 1995 \\
\hline & Santa Cruz/Graciosa ${ }^{4}$ & 20,1 & 21,0 & 1998 \\
\hline & Madalena/Aeródromo/Pico 5 & 20,1 & 20,7 & 1991 \\
\hline
\end{tabular}

\begin{tabular}{|c|c|c|c|c|}
\hline \multicolumn{5}{|c|}{$\begin{array}{l}\text { VALORES MEDIOS ANUALES MÁS BAJOS DE LA TEMPERATURA MÍNIMA DEL AIRE } \\
\text { MENORES VALORES MÉDIOS ANUAIS DA TEMPERATURA MÍNIMA DO AR } \\
\text { LOWEST ANNUAL AVERAGE VALUES FOR MINIMUM AIR TEMPERATURE }\end{array}$} \\
\hline \multirow{2}{*}{$\begin{array}{l}\text { Archipiélago } \\
\text { Arquipélago } \\
\text { Archipelago }\end{array}$} & \multirow{2}{*}{$\begin{array}{l}\text { Lugar } \\
\text { Local } \\
\text { Location }\end{array}$} & \multirow{2}{*}{$\begin{array}{c}\text { Media anual } \\
\text { Média anual } \\
\text { Annual average } \\
\left({ }^{\circ} \mathrm{C}\right)\end{array}$} & \multicolumn{2}{|c|}{$\begin{array}{l}\text { Media más baja } \\
\text { Menor média } \\
\text { Lowest average }\end{array}$} \\
\hline & & & $\left({ }^{\circ} \mathrm{C}\right)$ & Año/Ano/Year \\
\hline \multirow{5}{*}{ CANARIAS } & Izaña/Tenerife ${ }^{6}$ & 5,9 & 4,3 & 1971 \\
\hline & Los Rodeos/Tenerife 6 & 12,9 & 11,6 & 1972 \\
\hline & Tacoronte-A. S. E. A./Tenerife 7 & 14,4 & 13,2 & 1975 \\
\hline & \begin{tabular}{|l|} 
Fuerteventura/Aeropuerto \\
\end{tabular} & 17,2 & 15,7 & 1975 \\
\hline & Lanzarote/Aeropuerto ${ }^{8}$ & 16,9 & 15,5 & 1974 \\
\hline \multirow{5}{*}{ MADEIRA } & Arieiro $^{3}$ & 5,3 & 2,4 & 1994 \\
\hline & Bica da Cana & 5,6 & 0,9 & 1992 \\
\hline & Santo da Serra ${ }^{9}$ & 9,1 & 5,1 & 1986 \\
\hline & Camacha $^{10}$ & 11,1 & 9,5 & 1972 \\
\hline & Santana & 12,7 & 11,6 & 1972 \\
\hline \multirow{5}{*}{ AÇORES } & Cerrados Bezerros/São Miguel ${ }^{11}$ & 11,3 & 10,7 & 1982 \\
\hline & Furnas/São Miguel ${ }^{12}$ & 11,4 & 8,7 & 1988 \\
\hline & Fontinhas/Santa Maria ${ }^{13}$ & 11,7 & 10,0 & 1976 \\
\hline & Chá de Macela/São Miguel & 12,0 & 9,6 & 1996 \\
\hline & Capelo/Faial ${ }^{14}$ & 13,3 & 11,4 & 1979 \\
\hline
\end{tabular}

Serie de 27 años completos en el período 1971-2000 Série de 27 anos completos no período 1971-2000

Series of 27 complete years in the period $1971-2000$

2 Datos de 1971 a 1989

Dados de 1971 a 1989

Data from 1971 to 1989

3 Datos de 1971 a 1994

Dados de 1971 a 1994

Data from 1971 to 1994

4 Datos de 1978 a 2000

Dados de 1978 a 2000

Data from 1978 to 2000

5 Datos de 1983 a 1996

Dados de 1983 a 1996

Data from 1983 to 1996

6 Serie de 29 años completos en el período 1971-2000 Série de 29 anos completos no período 1971-2000

Series of 29 complete years in the period 1971-2000

Serie de 23 años completos en el período 1971-2000

Série de 23 anos completos no período 1971-2000

Series of 23 complete years in the period 1971-2000

8 Serie de 28 años completos en el período 1971-2000

Série de 28 anos completos no período 1971-2000

Series of 28 complete years in the period 1971-2000

9 Sin datos de temperatura mínima entre octubre de 1980 y diciembre de 1983 y entre febrero y septiembre de 1987

Sem dados de temperatura mínima entre outubro 1980 e dezembro 1983 e entre fevereiro e setembro de 1987

No data for minimum air temperature from October 1980 to

December 1983 and from February 1987 to September 1987

${ }^{10}$ Datos de 1971 a 1987

Dados de 1971 a 1987

Data from 1971 to 1987

${ }^{11}$ Datos de 1973 a 2000

Dados de 1973 a 2000

Data from 1973 to 2000

${ }^{12}$ Datos de 1979 a 2000

Dados de 1979 a 2000

Data from 1979 to 2000

13 Datos de 1971 a 1991

Dados de 1971 a 1991

Data from 1971 to 1991

${ }^{14}$ Datos de 1978 a 1994

Dados de 1978 a 1994

Data from 1978 to 1994 
Valores medios más altos diarios de temperatura máxima y mínima del aire en el período 1971-2000

Maiores valores médios diários da temperatura máxima e mínima do ar no período 1971-2000

Highest average daily values and extreme maximum and minimum air temperature values for the period 1971-2000

\begin{tabular}{|c|c|c|c|}
\hline \multicolumn{4}{|c|}{$\begin{array}{l}\text { VALORES EXTREMOS DE LA TEMPERATURA MÁXIMA DEL AIRE } \\
\text { VALORES EXTREMOS DA TEMPERATURA MÁXIMA DO AR } \\
\text { EXTREME VALUES FOR MAXIMUM AIR TEMPERATURE }\end{array}$} \\
\hline \multirow{2}{*}{$\begin{array}{l}\text { Archipiélago } \\
\text { Arquipélago } \\
\text { Archipelago }\end{array}$} & \multirow{2}{*}{$\begin{array}{l}\text { Lugar } \\
\text { Local } \\
\text { Location }\end{array}$} & \multicolumn{2}{|c|}{$\begin{array}{l}\text { Temperatura máxima }(1971-2000) \\
\text { Temperatura máxima }(1971-2000) \\
\text { Maximum temperature }(1971-2000)\end{array}$} \\
\hline & & $\left({ }^{\circ} \mathrm{C}\right)$ & Fecha/Data/Date \\
\hline \multirow{5}{*}{ CANARIAS } & Buenavista-Masca/Tenerife & 47,5 & $17 / 07 / 1978$ \\
\hline & Sabinar-Lomo Negro/El Hierro & 47,0 & $24 / 08 / 1986$ \\
\hline & Tacoronte-A. S. E. A./Tenerife & 46,0 & 09/08/1976 \\
\hline & \begin{tabular}{|l|} 
Punta Orchilla-Faro/El Hierro \\
\end{tabular} & 45,9 & 06/09/1986 \\
\hline & La Oliva-Taca/Fuerteventura & 45,5 & 04/07/1994 \\
\hline \multirow{5}{*}{ MADEIRA } & Funchal/Observatório & 38,5 & $10 / 08 / 1976$ \\
\hline & Funchal/Observatório & 38,4 & 08/09/1987 \\
\hline & Santa Catarina/Aeroporto & 37,3 & 09/09/1988 \\
\hline & Porto Santo/Aeroporto & 35,3 & 06/08/1990 \\
\hline & Santo da Serra & 35,0 & $10 / 08 / 1976$ \\
\hline \multirow{5}{*}{ AÇORES } & Madalena/Aeródromo/Pico & 32,2 & 07/09/1985 \\
\hline & Horta/Faial & 30,6 & 01/09/1989 \\
\hline & Lajes/Aeroporto/Terceira & 30,5 & $26 / 08 / 1980$ \\
\hline & Santa Cruz Flores/Aeroporto & 30,0 & 10/08/1988 \\
\hline & $\begin{array}{l}\text { Santa Cruz/Graciosa } \\
\text { Cerrados Bezerros/São Miguel }\end{array}$ & 29,5 & $\begin{array}{l}07 / 09 / 1985 \\
05 / 08 / 1991\end{array}$ \\
\hline
\end{tabular}

\begin{tabular}{|c|c|c|c|}
\hline \multicolumn{4}{|c|}{$\begin{array}{l}\text { VALORES EXTREMOS DE LA TEMPERATURA MÍNIMA DEL AIRE } \\
\text { VALORES EXTREMOS DA TEMPERATURA MÍNIMA DO AR } \\
\text { EXTREME VALUES FOR MINIMUM AIR TEMPERATURE }\end{array}$} \\
\hline \multirow{2}{*}{$\begin{array}{l}\text { Archipiélago } \\
\text { Arquipélago } \\
\text { Archipelago }\end{array}$} & \multirow{2}{*}{$\begin{array}{l}\text { Lugar } \\
\text { Local } \\
\text { Location }\end{array}$} & \multicolumn{2}{|c|}{$\begin{array}{l}\text { Temperatura mínima }(1971-2000) \\
\text { Temperatura mínima }(1971-2000) \\
\text { Minimum temperature }(1971-2000)\end{array}$} \\
\hline & & $\left({ }^{\circ} \mathrm{C}\right)$ & Fecha/Data/Date \\
\hline \multirow{5}{*}{ CANARIAS } & Las Cañadas-Pico Teide/Tenerife & $-16,0$ & 17/02/1991 \\
\hline & Izaña/Tenerife & $-9,8$ & 26/02/1971 \\
\hline & Garafía-Roque de los Muchachos/La Palma & $-8,0$ & 28/01/1990 \\
\hline & Tejeda-Cruz de Tejeda/Gran Canaria & $-4,0$ & 21/01/1997 \\
\hline & Vallehermoso-Laguna Grande/La Gomera & $-3,3$ & 16/01/1989 \\
\hline \multirow{5}{*}{ MADEIRA } & Bica da Cana & $-9,5$ & 05/03/1993 \\
\hline & Bica da Cana & $-8,2$ & $31 / 12 / 1992$ \\
\hline & Bica da Cana & $-8,0$ & $02 / 04 / 1993$ \\
\hline & Bica da Cana & $-7,5$ & $\begin{array}{l}30 / 03 / 1992 \\
04 / 04 / 1992 \\
\end{array}$ \\
\hline & Arieiro & $-7,0$ & 06/03/1994 \\
\hline \multirow{5}{*}{ AÇORES } & Cerrados Bezerros/São Miguel & 0,3 & $\begin{array}{l}11 / 03 / 1973 \\
20 / 02 / 1976 \\
\end{array}$ \\
\hline & Cerrados Bezerros/São Miguel & 0,5 & $30 / 04 / 1976$ \\
\hline & Chá de Macela/São Miguel & 0,5 & $15 / 01 / 1975$ \\
\hline & Furnas/São Miguel & 0,5 & $\begin{array}{l}08 / 02 / 1997 \\
31 / 03 / 1989 \\
\end{array}$ \\
\hline & Cerrados Bezerros/São Miguel & 0,6 & 26/01/1973 \\
\hline
\end{tabular}


Normales climatológicas de la temperatura del aire en las Islas Canarias (1971-2000) /

Normais climatológicas da temperatura do ar nas Ilhas Canárias (1971-2000) /

Climate normal values for air temperature in the Canary Islands (1971-2000)
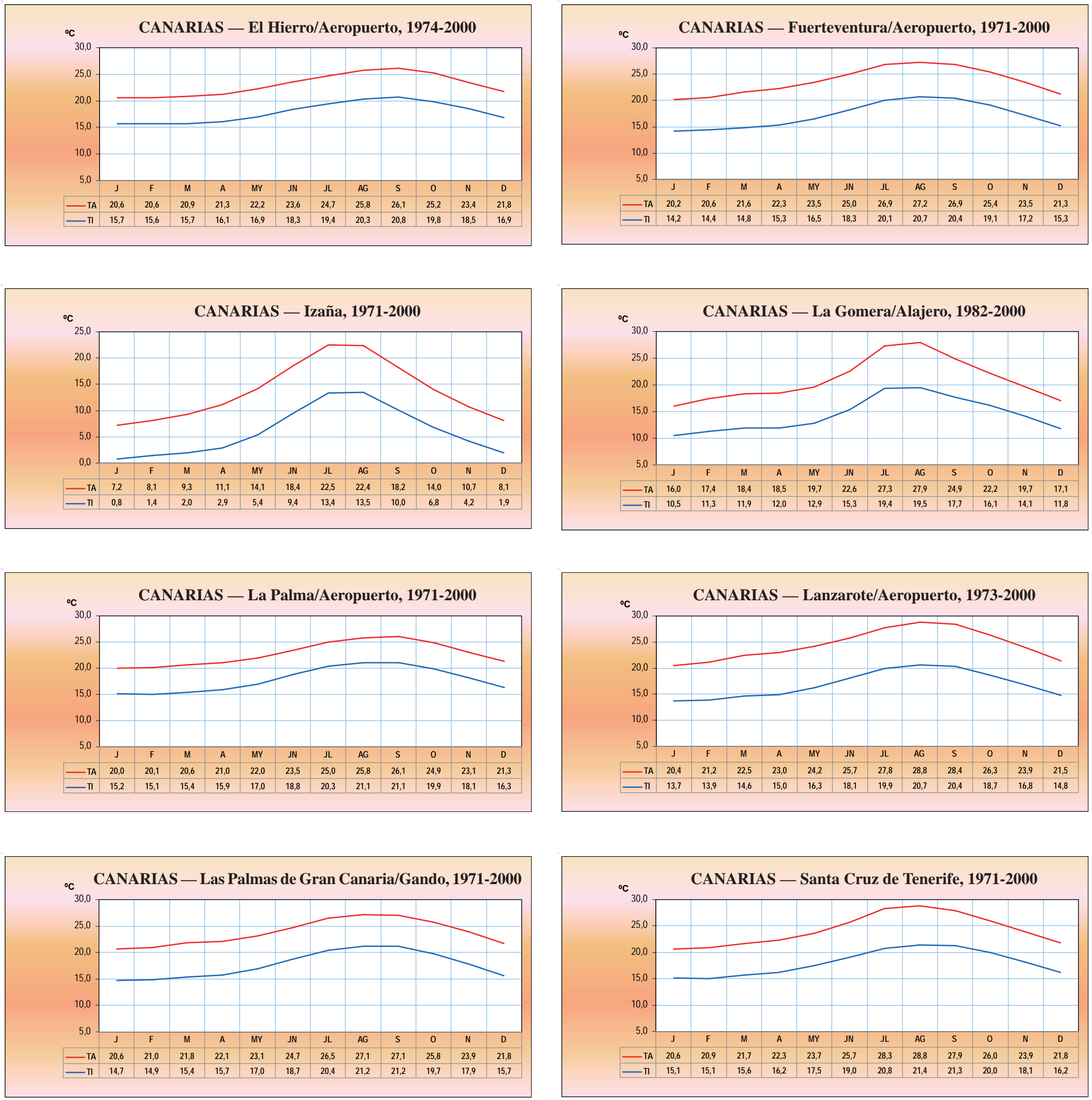

J, F, M, A, MY, JN, JL, AG, S, O, N, D

Enero, febrero, marzo, abril, mayo, junio, julio, agosto, septiembre, octubre, noviembre, diciembre

Enero, Fevereiro, Marco, Abril, Maio, Junho, Julho, Agosto, Setembro, Outubro, Novembro, Dezembro

January, February, March, April, May, June, July, August, September, October, November, December

TA Temperatura media de las máximas

Média da temperatura máxima

Average maximum temperature

TI Temperatura media de las mínimas

Média da temperatura mínima

Average minimum temperature 
Normales climatológicas de la temperatura del aire en el archipiélago de Madeira (1971-2000) /

Normais climatológicas da temperatura do ar no arquipélago da Madeira (1971-2000) /

Climate normal values for air temperature in the archipelago of Madeira (1971-2000)
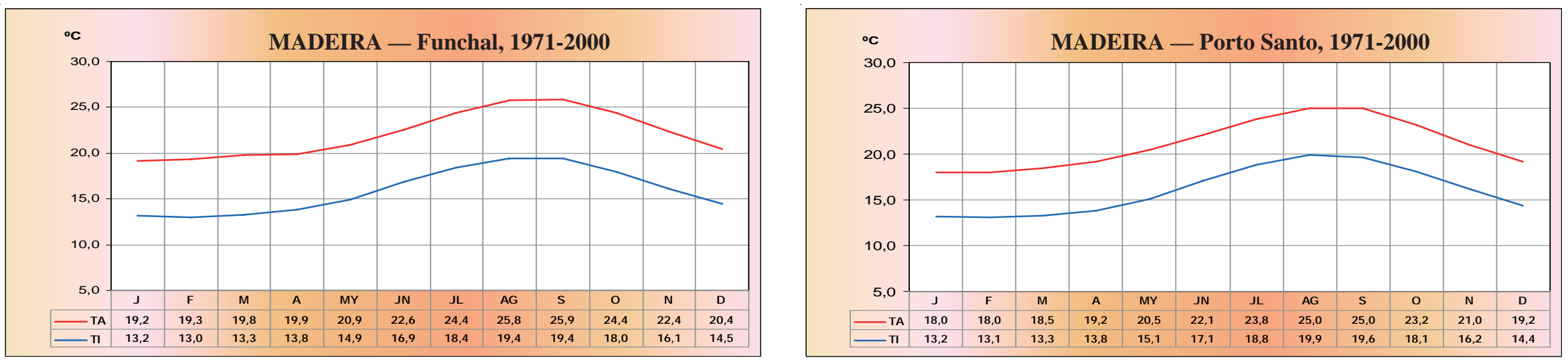

J, F, M, A, MY, JN, JL, AG, S, O, N, D

Enero, febrero, marzo, abril, mayo, junio, julio, agosto, septiembre, octubre, noviembre, diciembre

Enero, Fevereiro, Março, Abril, Maio, Junho, Julho, Agosto, Setembro, Outubro, Novembro, Dezembro

January, February, March, April, May, June, July, August, September, October, November, December

TA Temperatura media de las máximas

Média da temperatura máxima

Average maximum temperature

TI Temperatura media de las mínimas

Média da temperatura mínima

Average minimum temperature 
Normales climatológicas de la temperatura del aire en el archipiélago de Azores (1971-2000) /

Normais climatológicas da temperatura do ar no arquipélago dos Açores (1971-2000) /

Climate normal values for air temperature in the archipelago of the Azores (1971-2000)
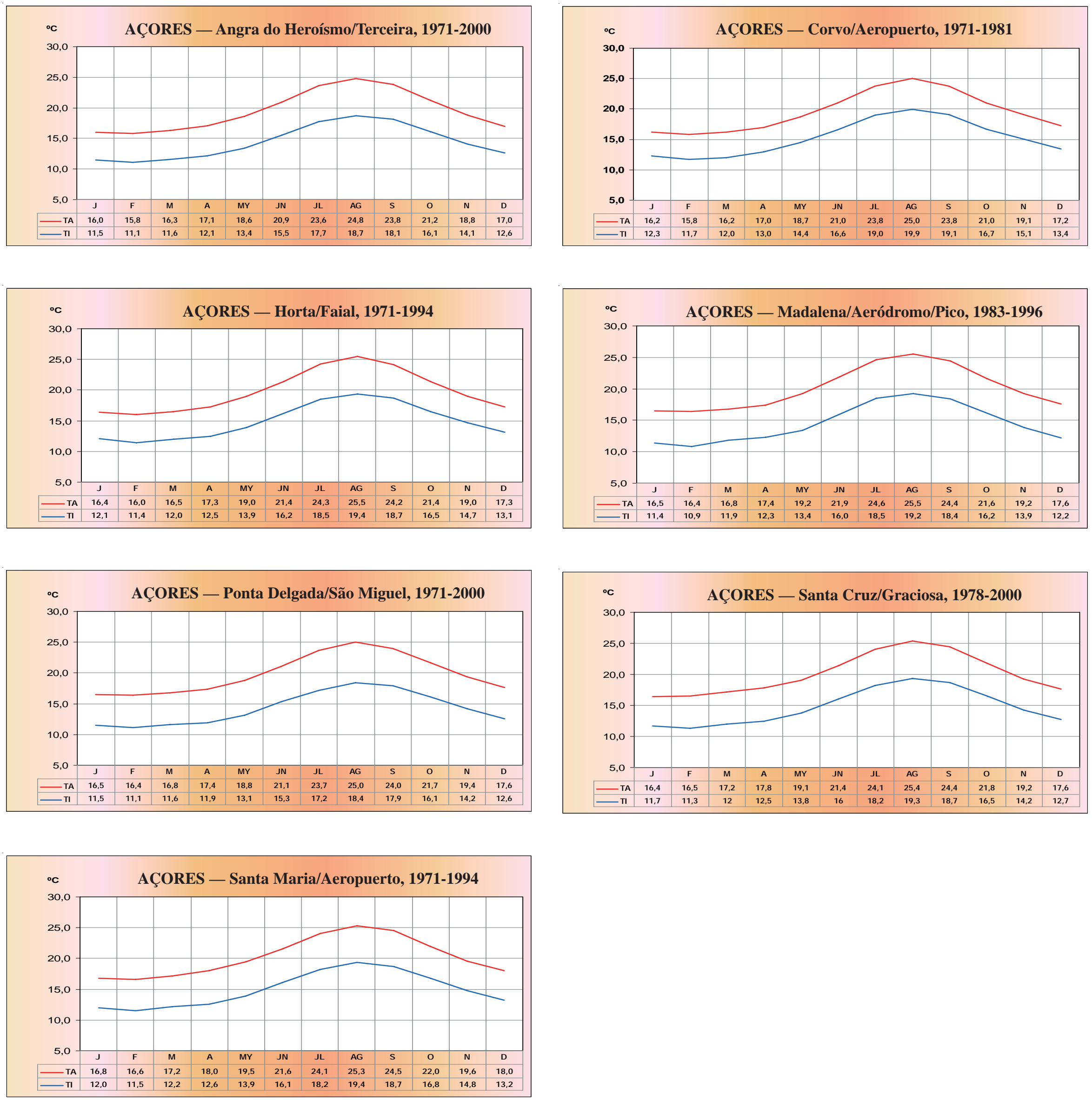

J, F, M, A, MY, JN, JL, AG, S, O, N, D

Enero, febrero, marzo, abril, mayo, junio, julio, agosto, septiembre, octubre, noviembre, diciembre

Enero, Fevereiro, Marco, Abril, Maio, Junho, Julho, Agosto, Setembro, Outubro, Novembro, Dezembro

January, February, March, April, May, June, July, August, September, October, November, December

TA Temperatura media de las máximas

Média da temperatura máxima

Average maximum temperature

TI Temperatura media de las mínimas

Média da temperatura mínima

Average minimum temperature 
Red climatológica de medida de la temperatura del aire para los archipiélagos de Canarias, Madeira y Azores / Rede climatológica da temperatura do ar nos arquipélagos das Canárias, da Madeira e dos Açores /

Climate network for air temperature in the archipelagos of the Canary Islands, Madeira and the Azores

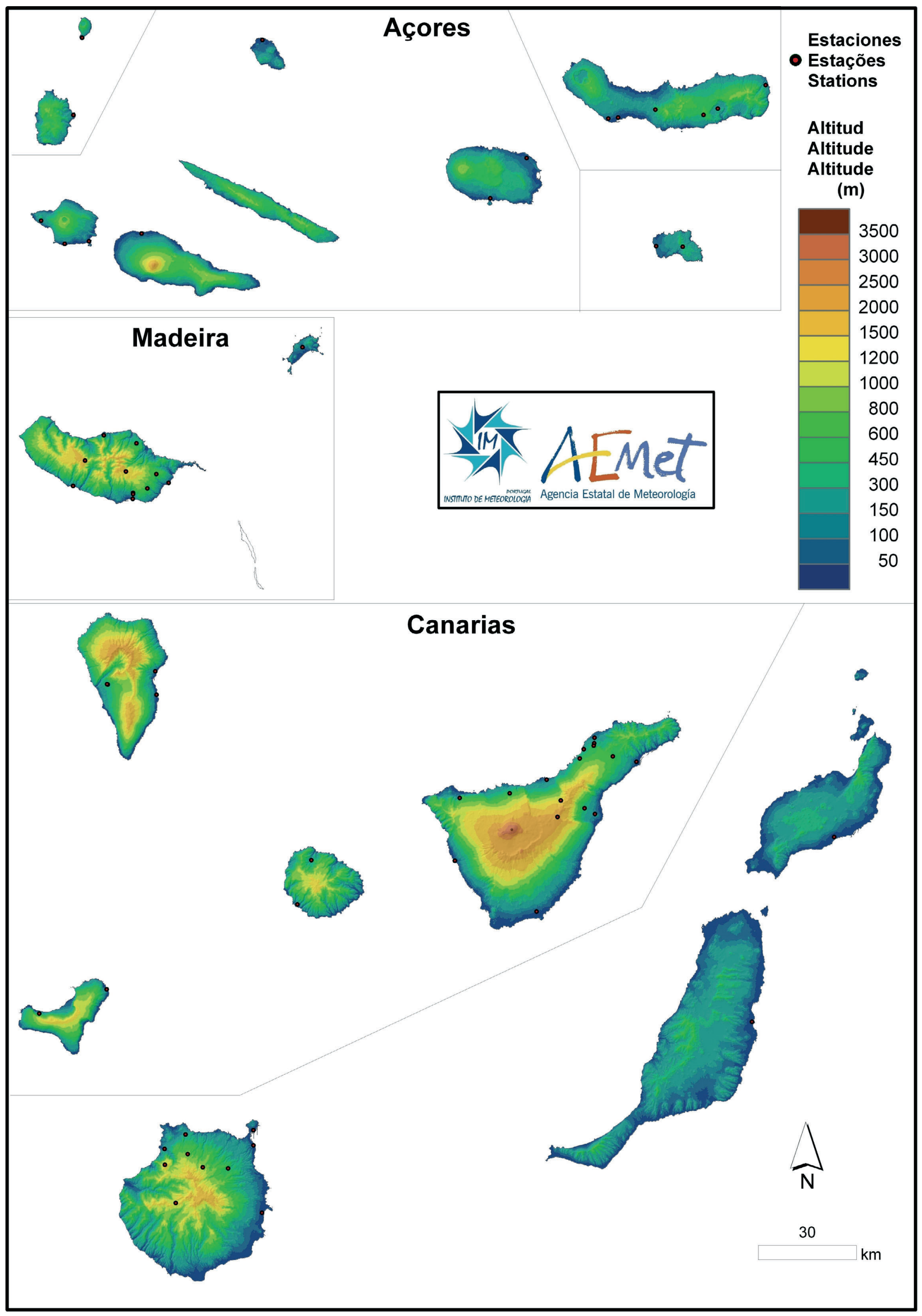

Fig. 4. Red de estaciones climatológicas de la temperatura del aire para los archipiélagos de Canarias, Madeira y Azores.

Rede climatológica da temperatura do ar nos arquipélagos das Canárias, da Madeira e dos Açores.

Climate network for air temperature in the archipelagos of the Canary Islands, Madeira and the Azores. 
Temperatura media del aire en los archipiélagos de Canarias, Madeira y Azores (1971-2000) /

Temperatura média do ar nos arquipélagos das Canárias, da Madeira e dos Açores (1971-2000) /

Mean air temperature in the archipelagos of the Canary Islands, Madeira and the Azores (1971-2000)

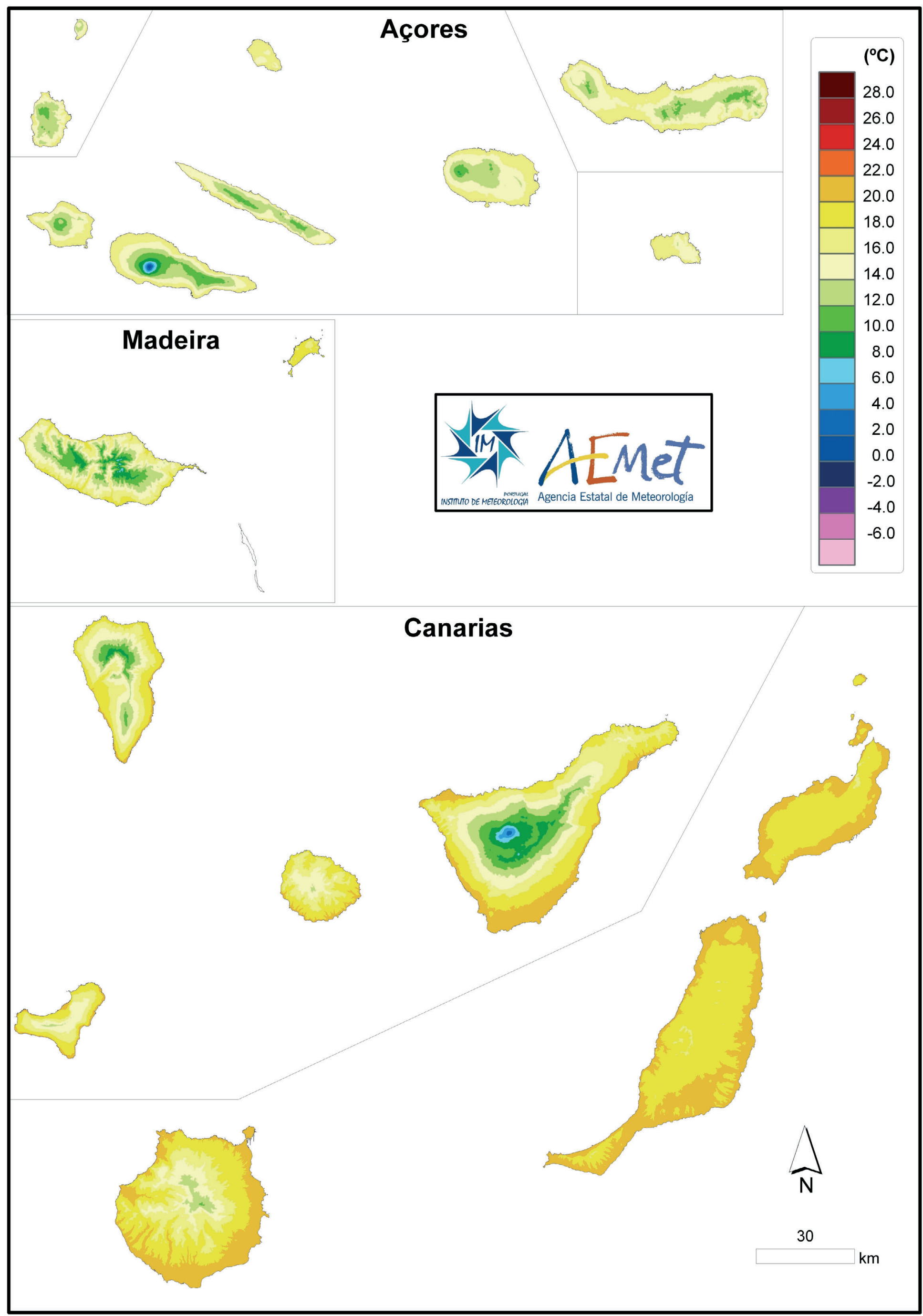

Fig. 5. Temperatura media anual.

Média da temperatura média anual.

Annual average mean temperature. 


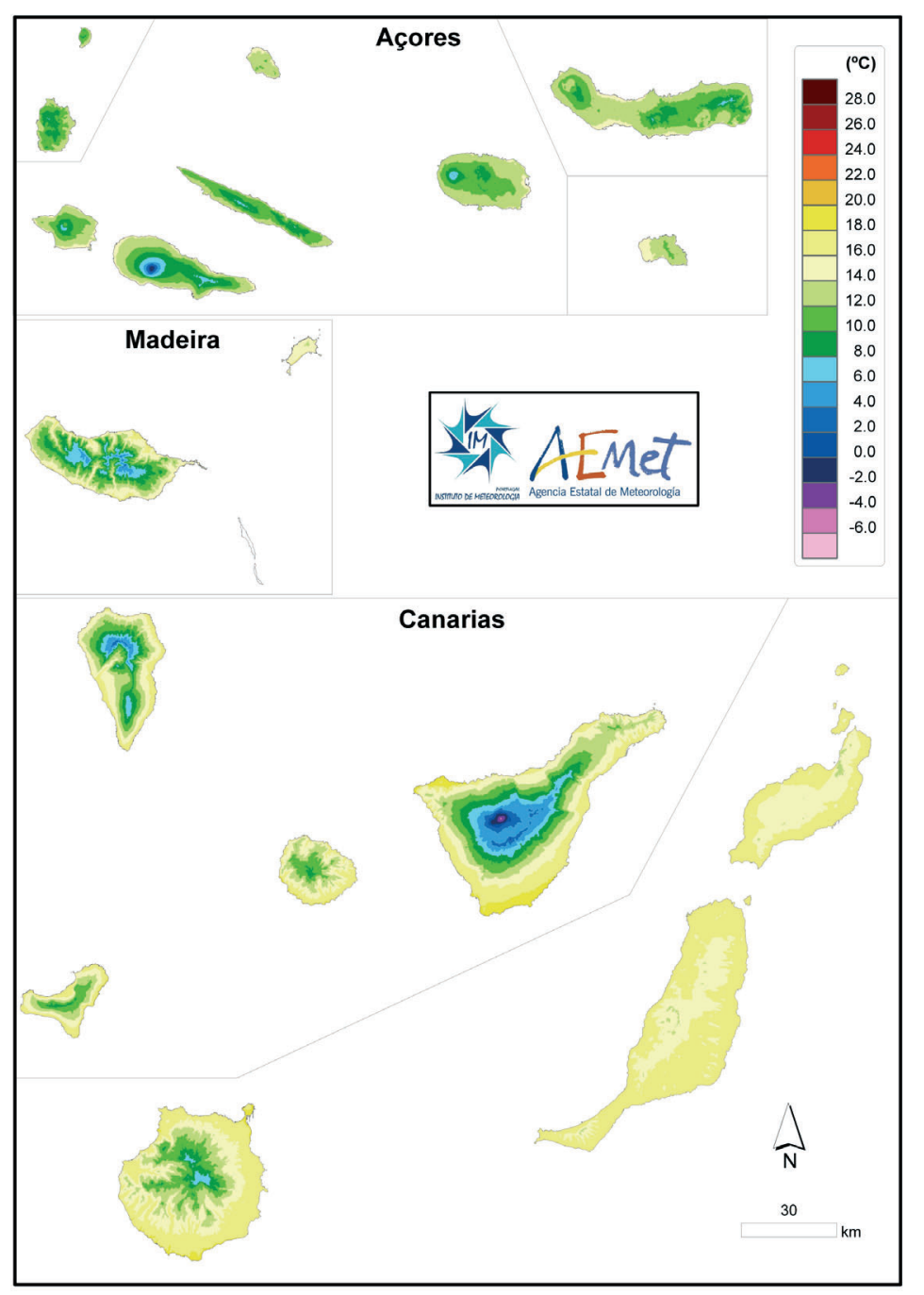

Fig. 6. Temperatura media de enero.

Média da temperatura média em Janeiro.

Average mean temperature in January.

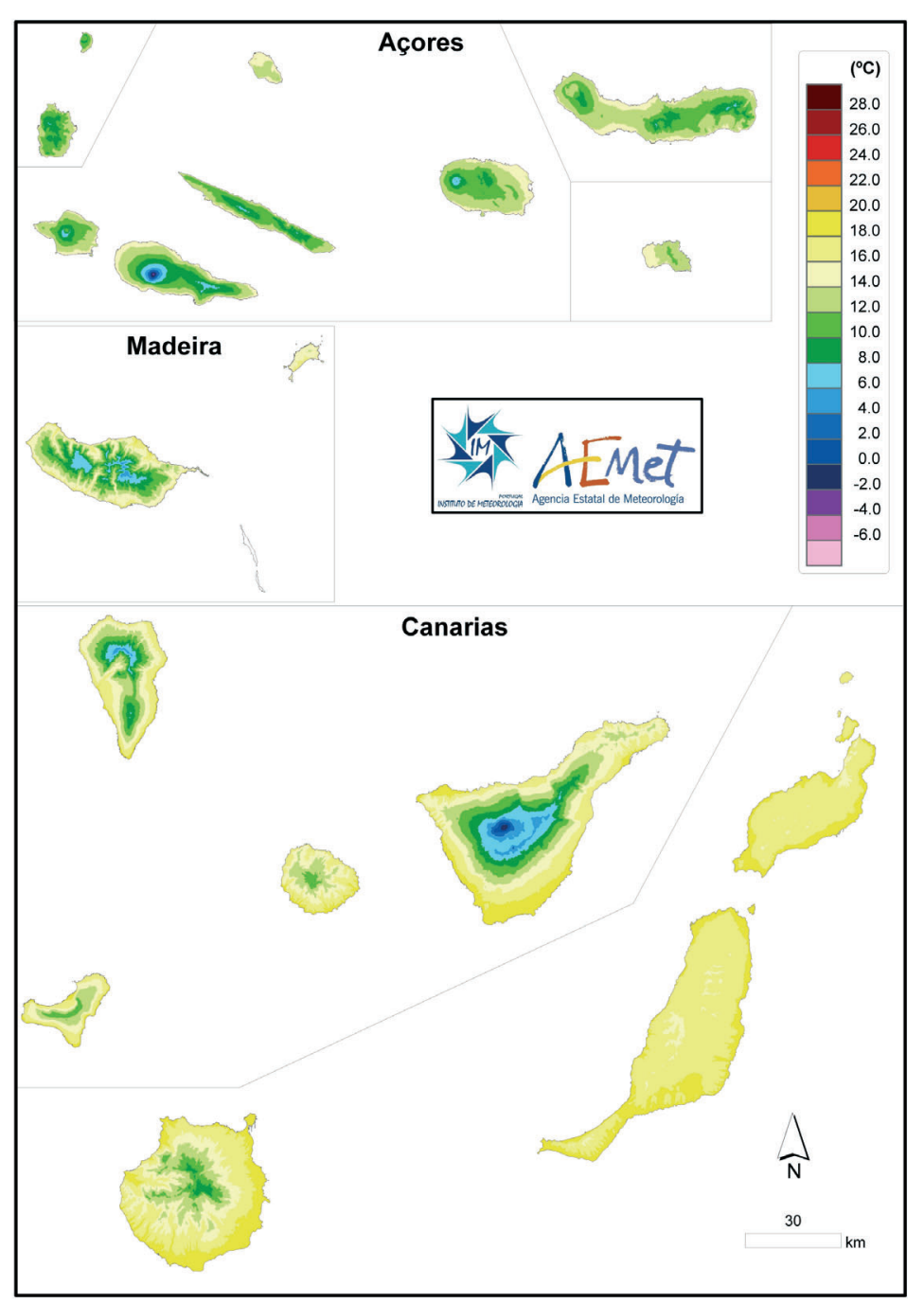

Fig. 8. Temperatura media de marzo.

Média da temperatura média em Março.

Average mean temperature in March.

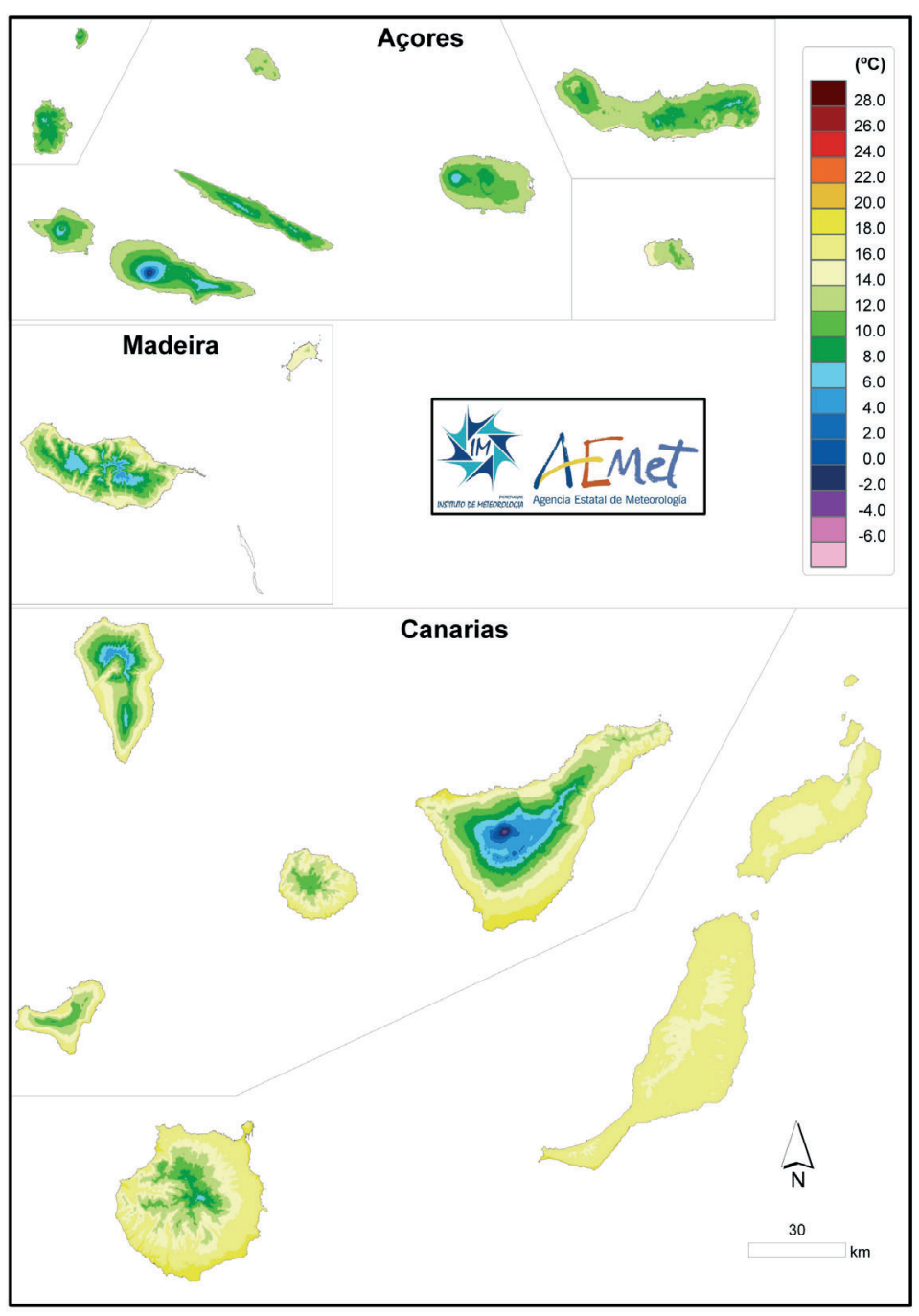

Fig. 7. Temperatura media de febrero.

Média da temperatura média em Fevereiro.

Average mean temperature in February.

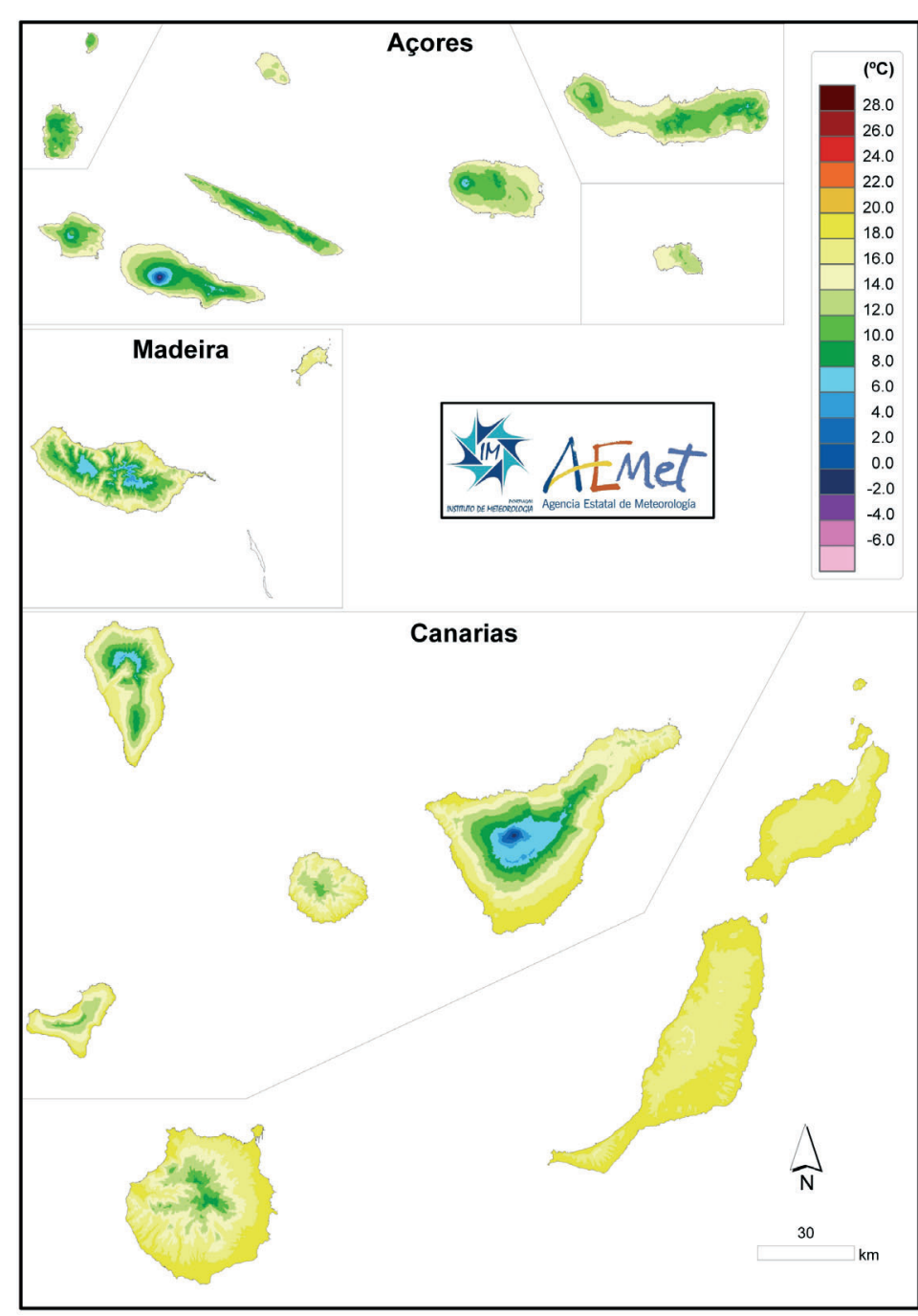

Fig. 9. Temperatura media de abril.

Média da temperatura média em Abril.

Average mean temperature in April. 


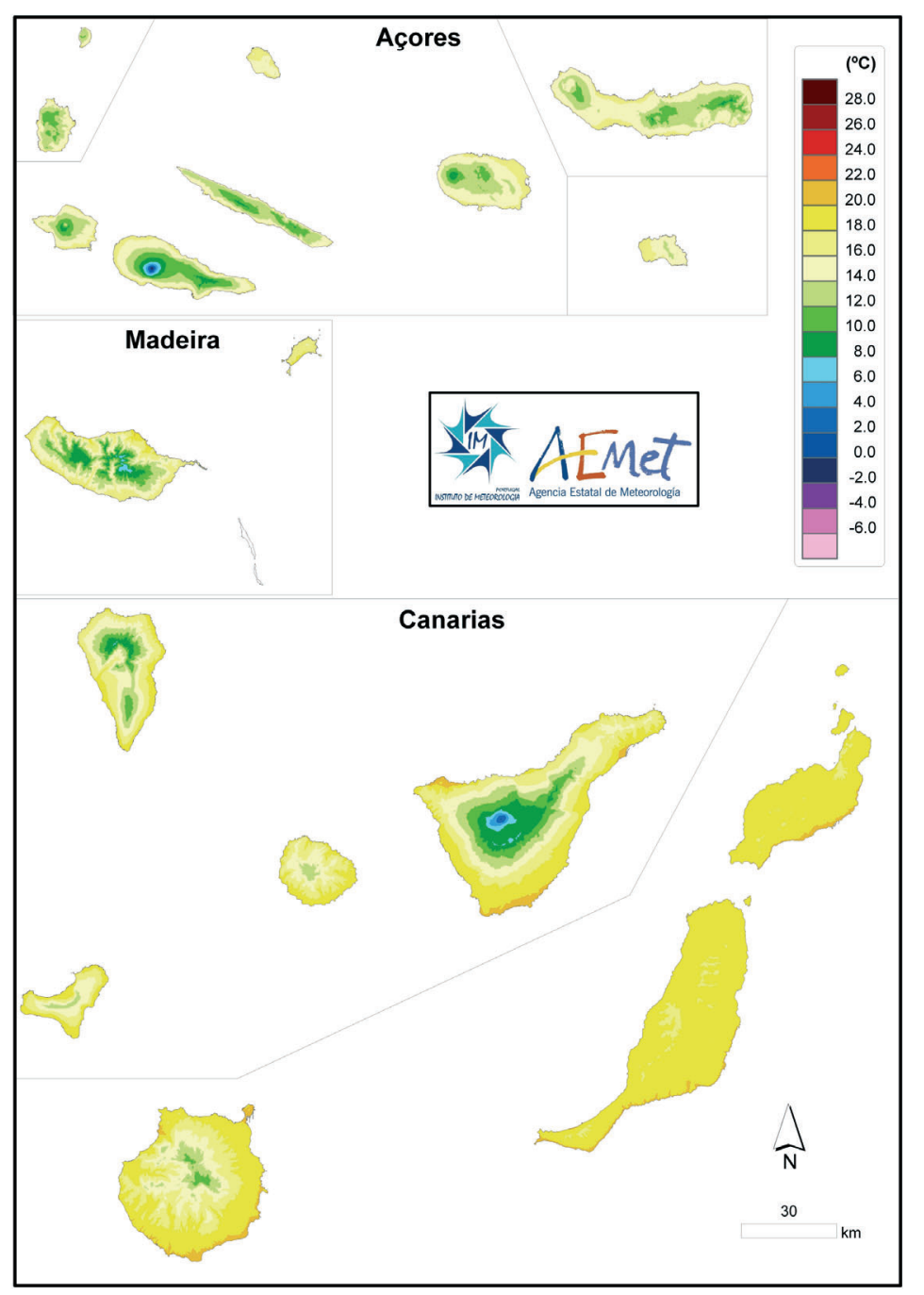

Fig. 10. Temperatura media de mayo.

Média da temperatura média em Maio.

Average mean temperature in May.

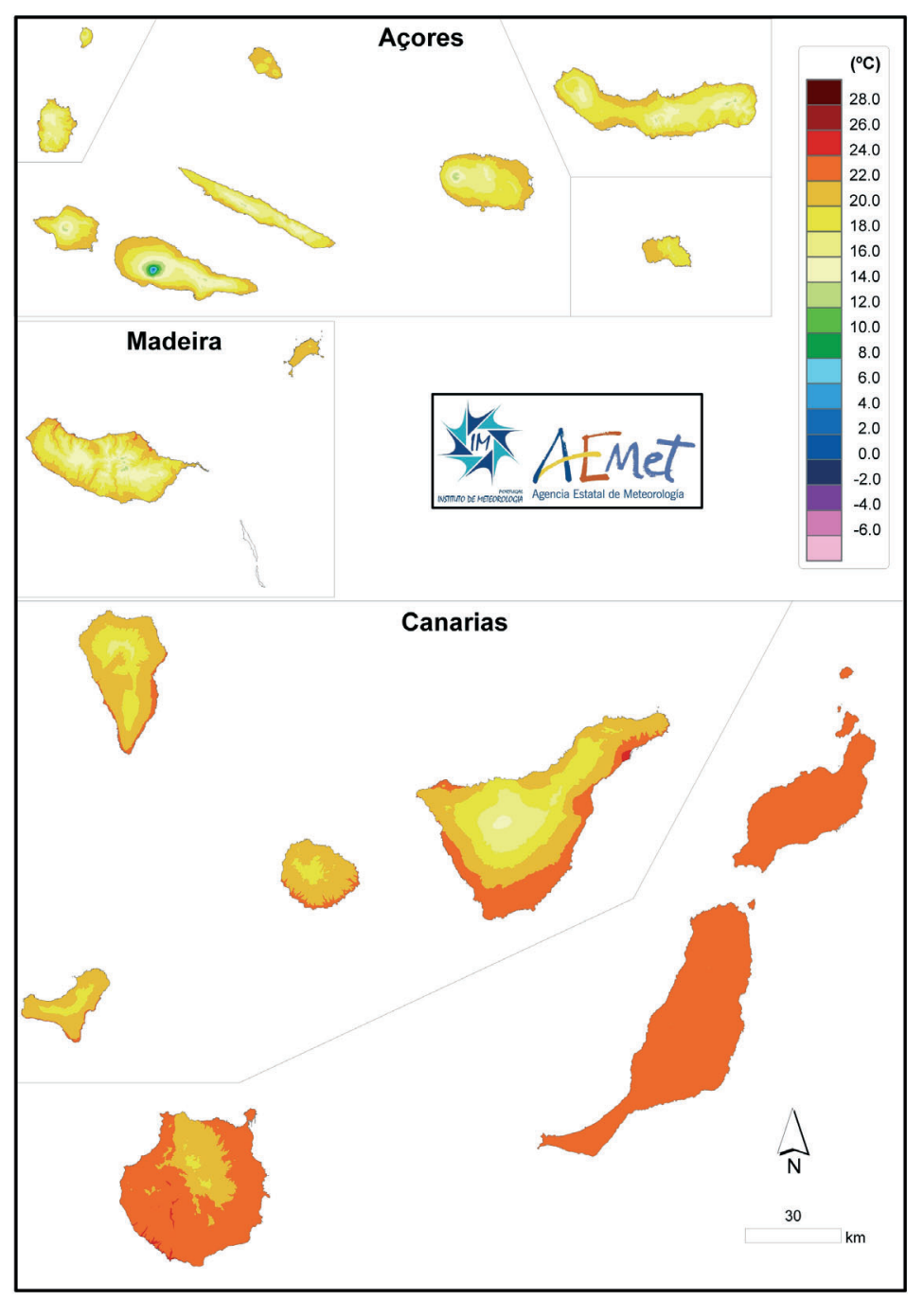

Fig. 12. Temperatura media de julio.

Média da temperatura média em Julho.

Average mean temperature in July.

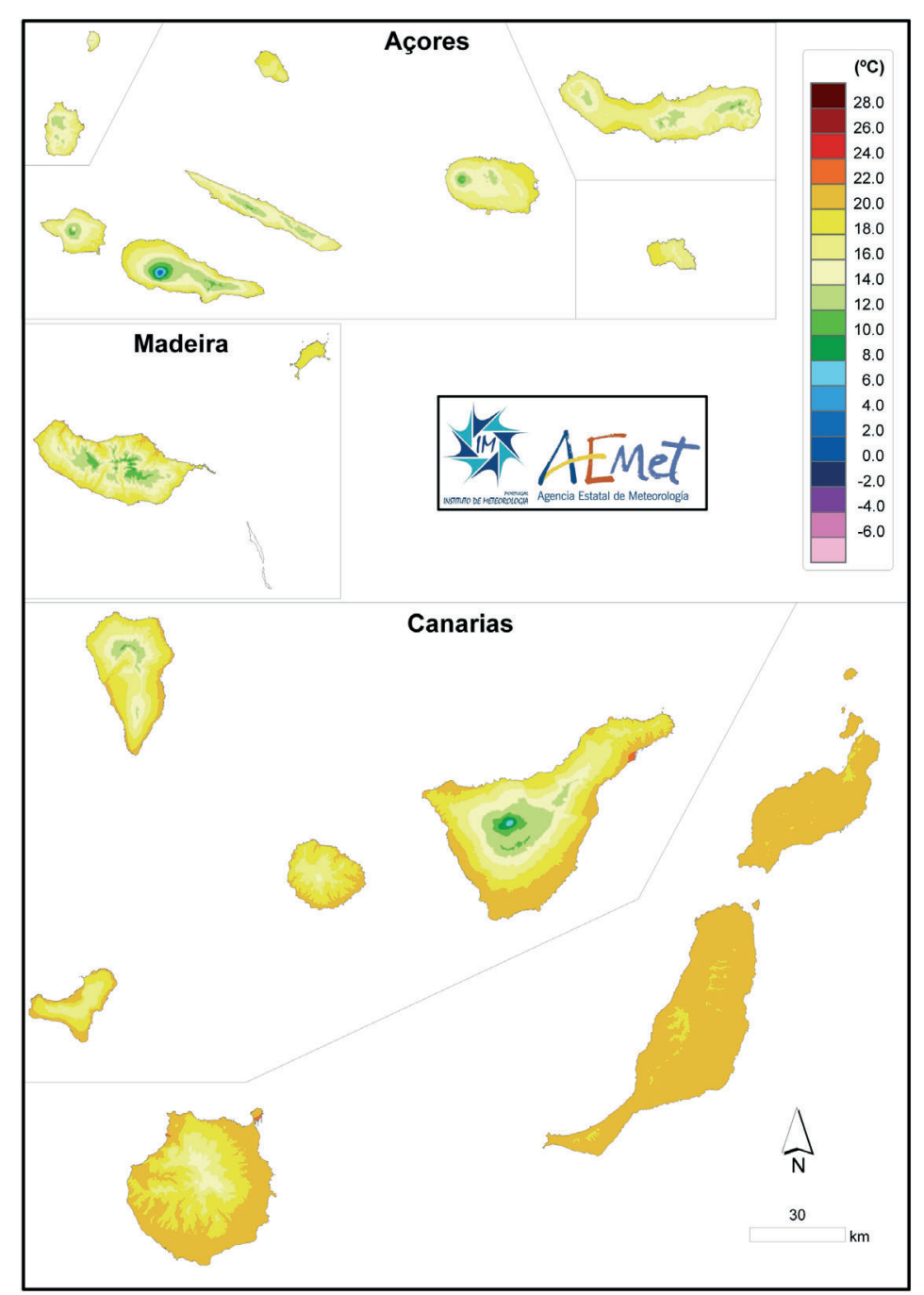

Fig. 11. Temperatura media de junio.

Média da temperatura média em Junho.

Average mean temperature in June.

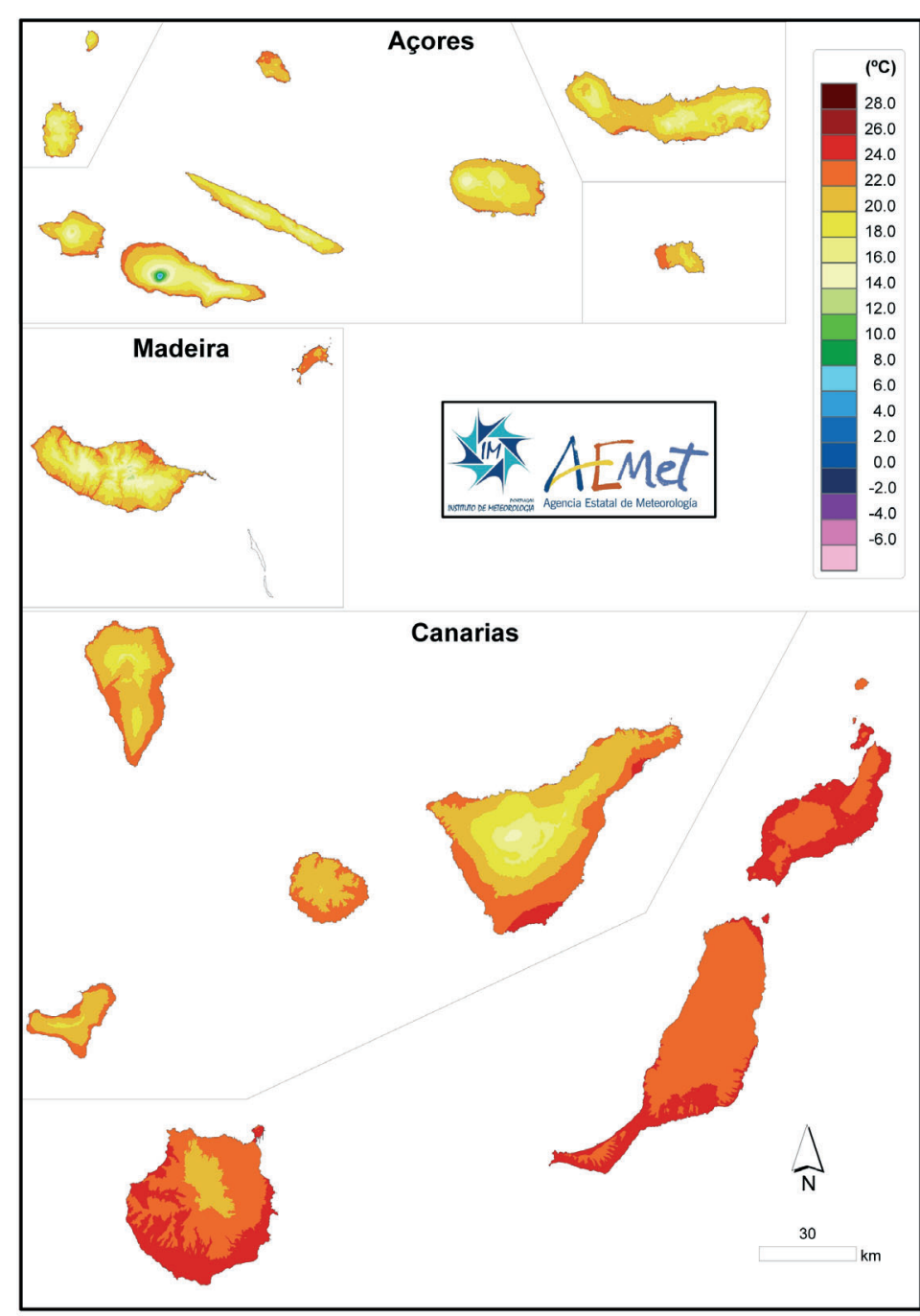

Fig. 13. Temperatura media de agosto.

Média da temperatura média em Agosto.

Average mean temperature in August. 


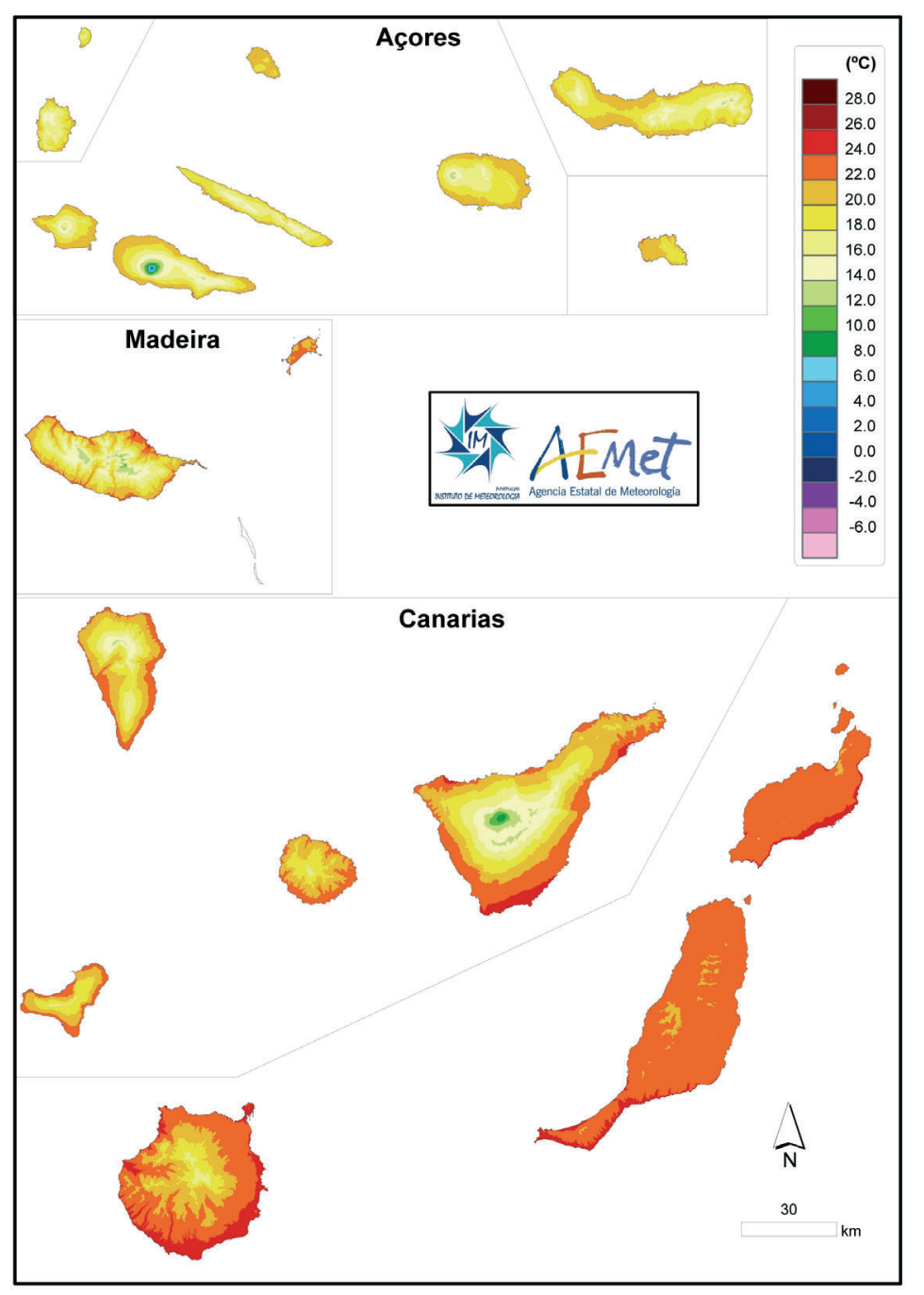

Fig. 14. Temperatura media de septiembre.

Média da temperatura média em Setembro.

Average mean temperature in September.

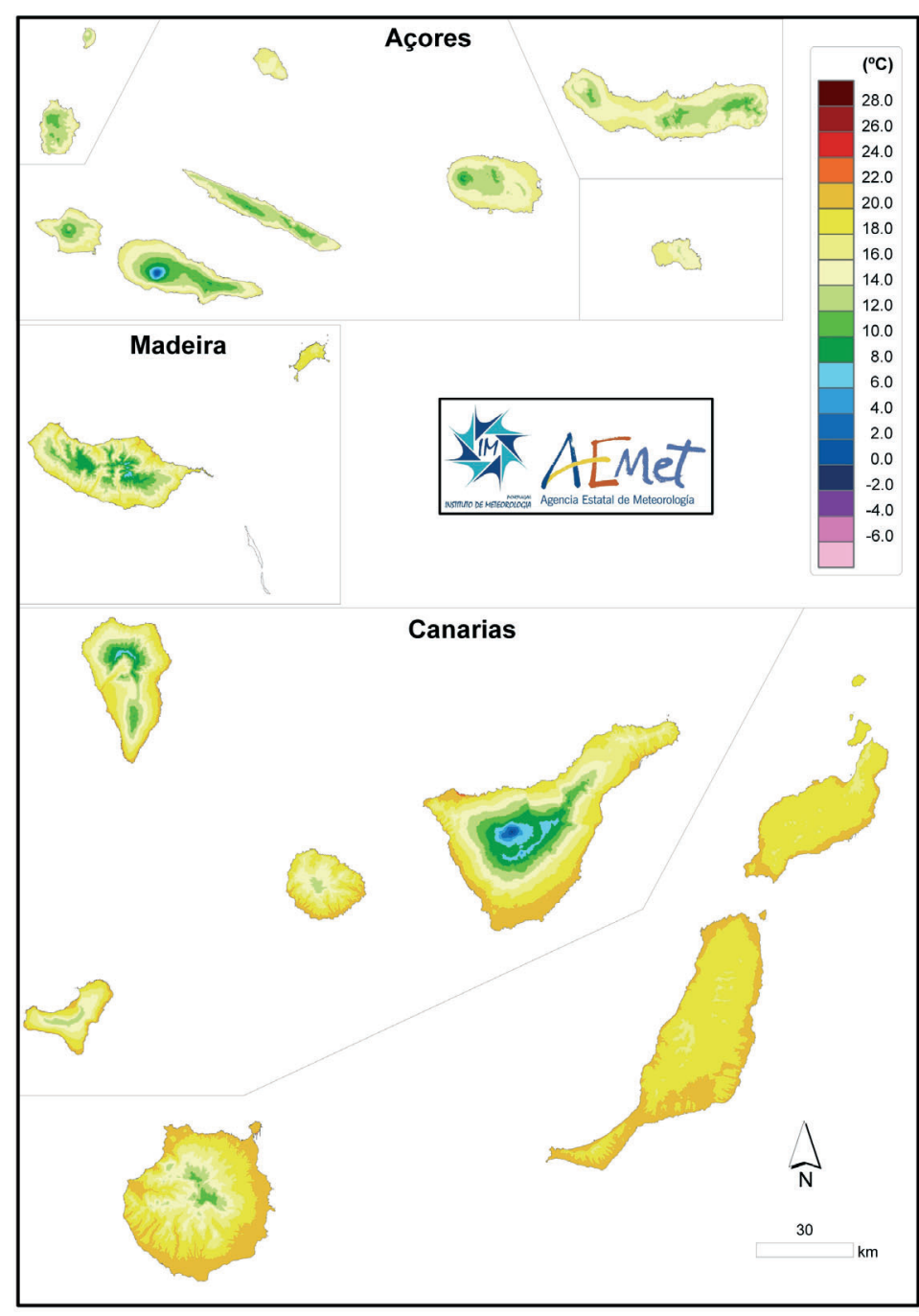

Fig. 16. Temperatura media de noviembre.

Média da temperatura média em Novembro.

Average mean temperature in November.

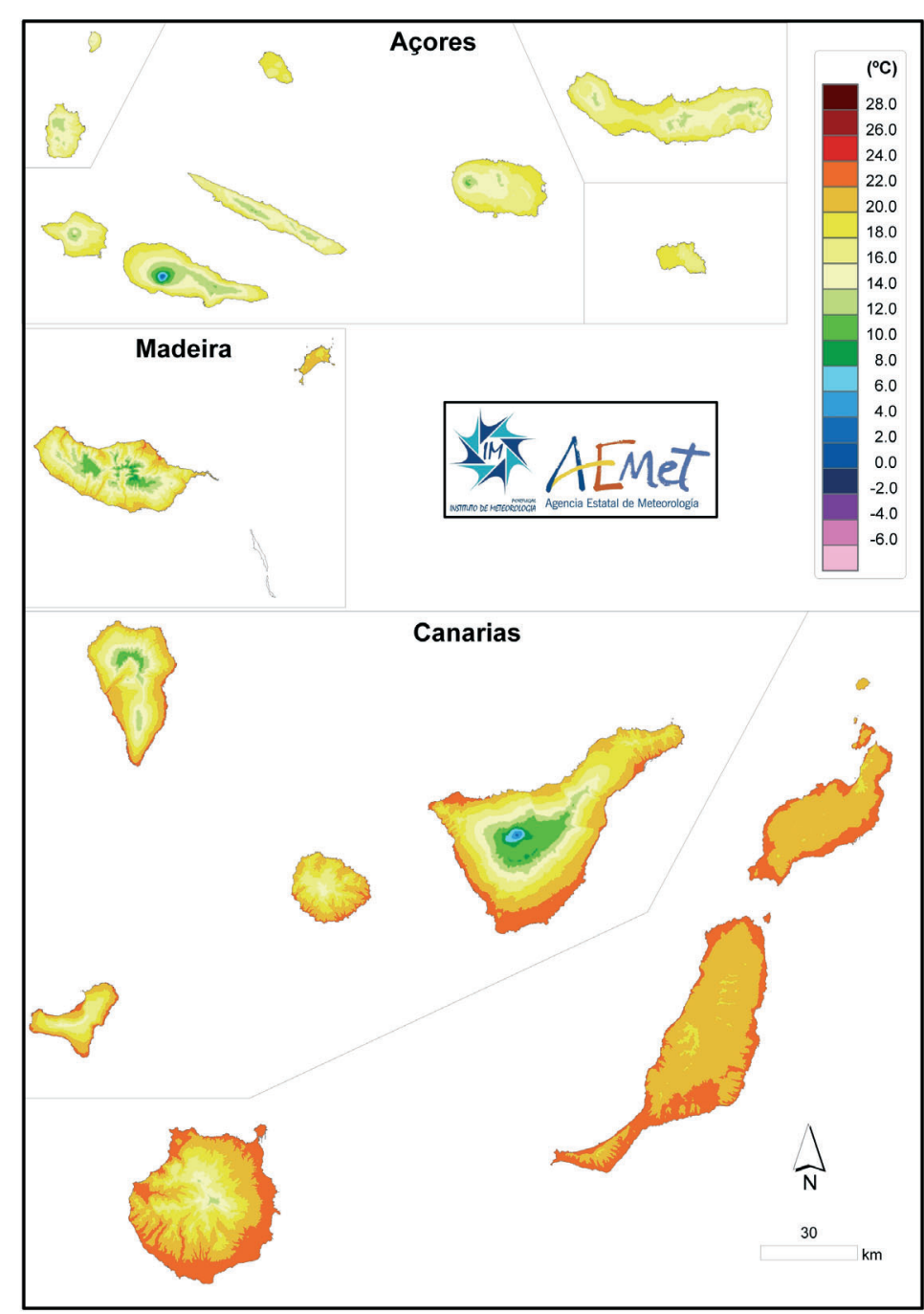

Fig. 15. Temperatura media de octubre.

Média da temperatura média em Outubro.

Average mean temperature in October.

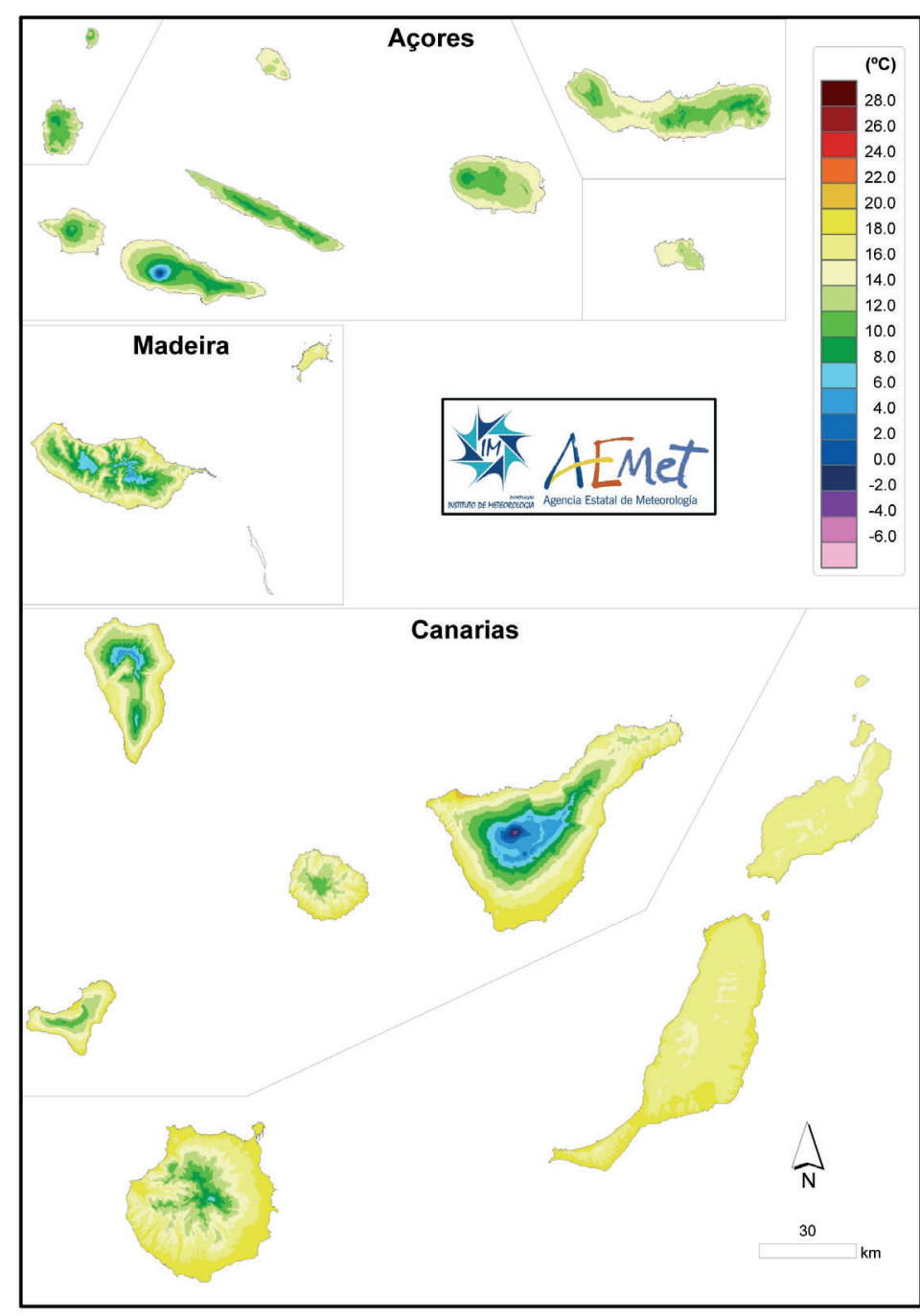

Fig. 17. Temperatura media de diciembre.

Média da temperatura média em Dezembro.

Average mean temperature in December. 


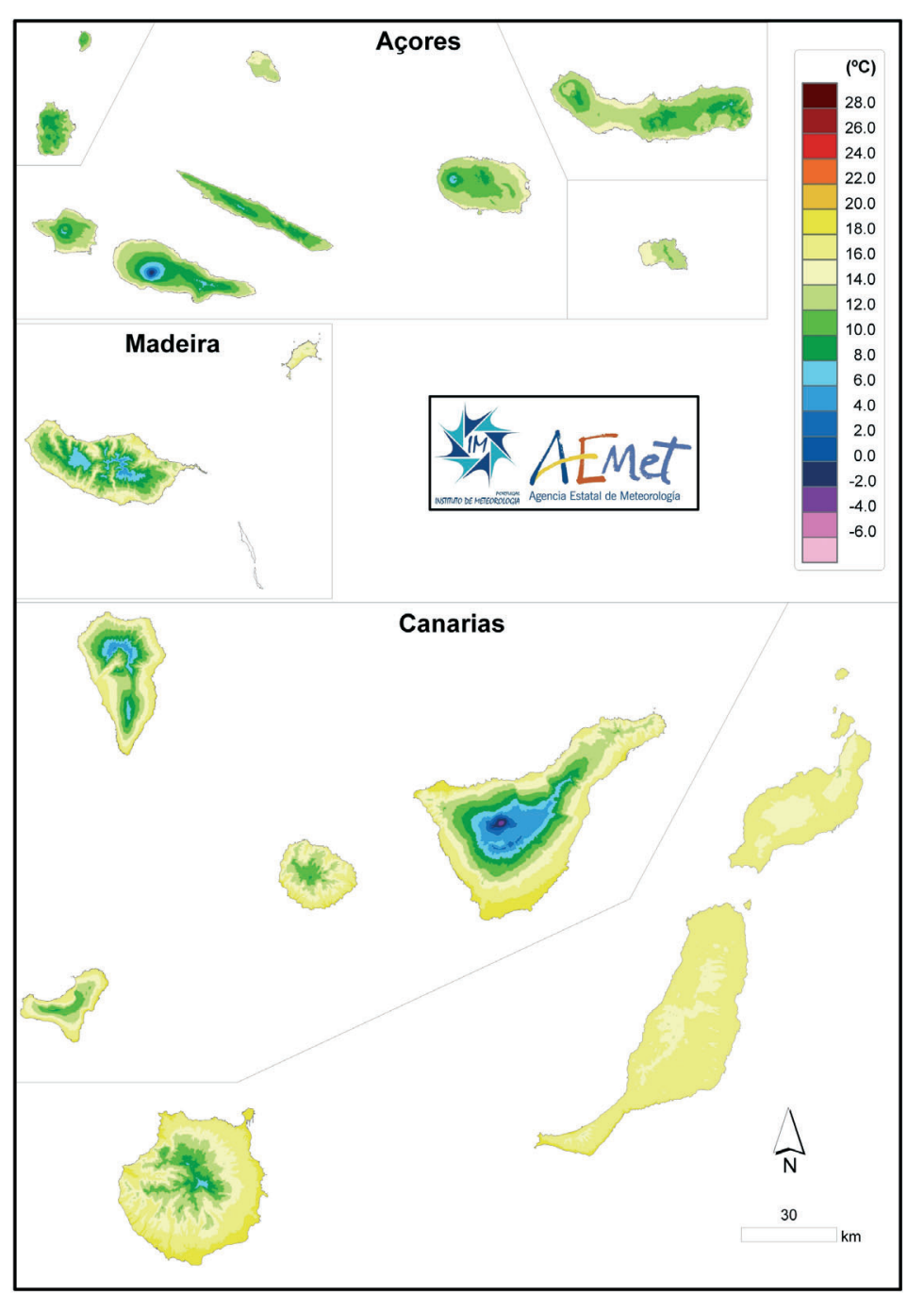

Fig. 18. Temperatura media en invierno.

Média da temperatura média no Inverno.

Average mean temperature in winter.

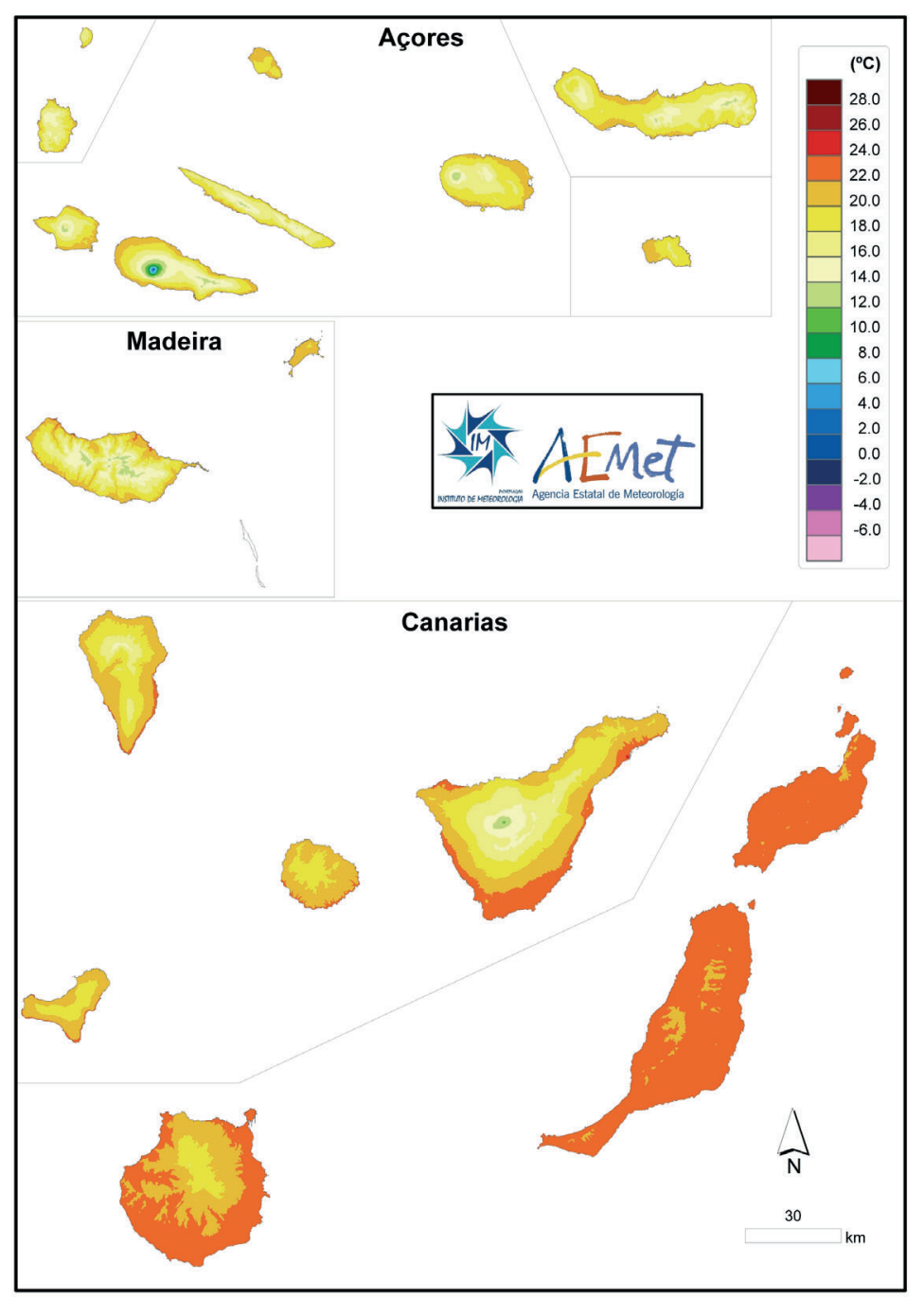

Fig. 20. Temperatura media en verano.

Média da temperatura média no Verão.

Average mean temperature in summer.

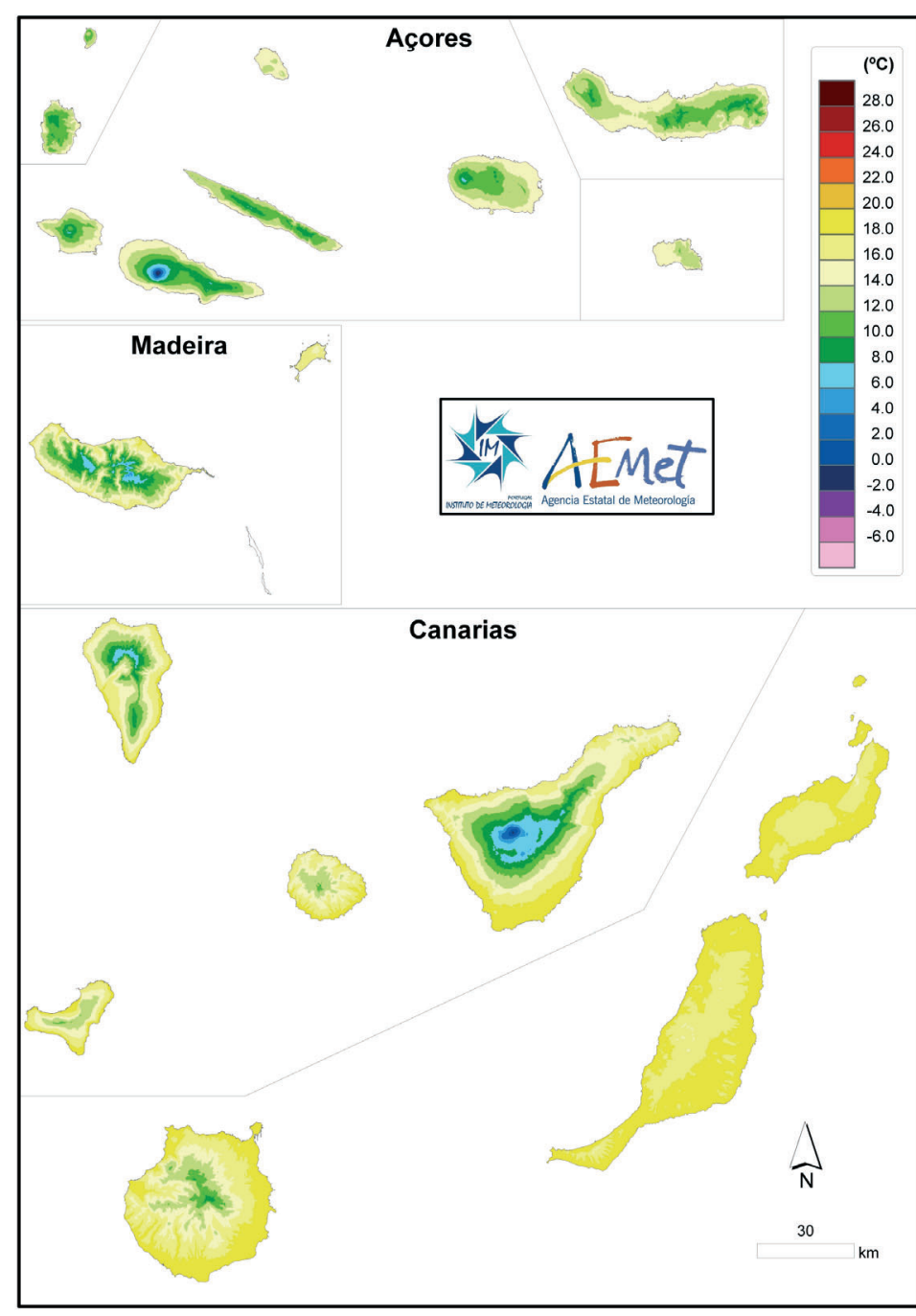

Fig. 19. Temperatura media en primavera.

Média da temperatura média na Primavera.

Average mean temperature in spring.

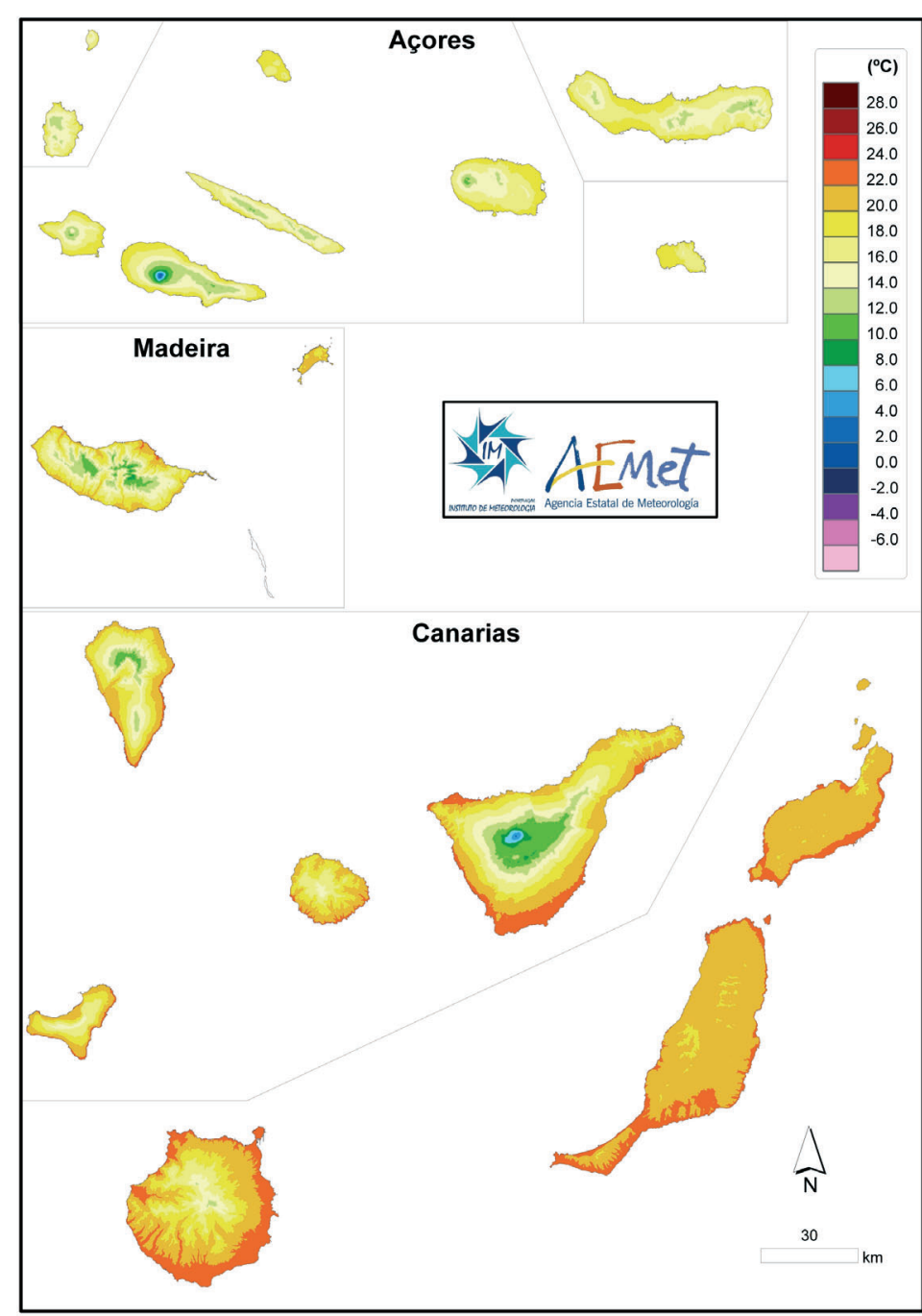

Fig. 21. Temperatura media en otoño.

Média da temperatura média no Outono.

Average mean temperature in autumn. 
Temperatura media de las mínimas en los archipiélagos de Canarias, Madeira y Azores (1971-2000) /

Média da temperatura mínima do ar nos arquipélagos das Canárias, da Madeira e dos Açores (1971-2000) / Average minimum air temperature in the archipelagos of the Canary Islands, Madeira and the Azores (1971-2000)

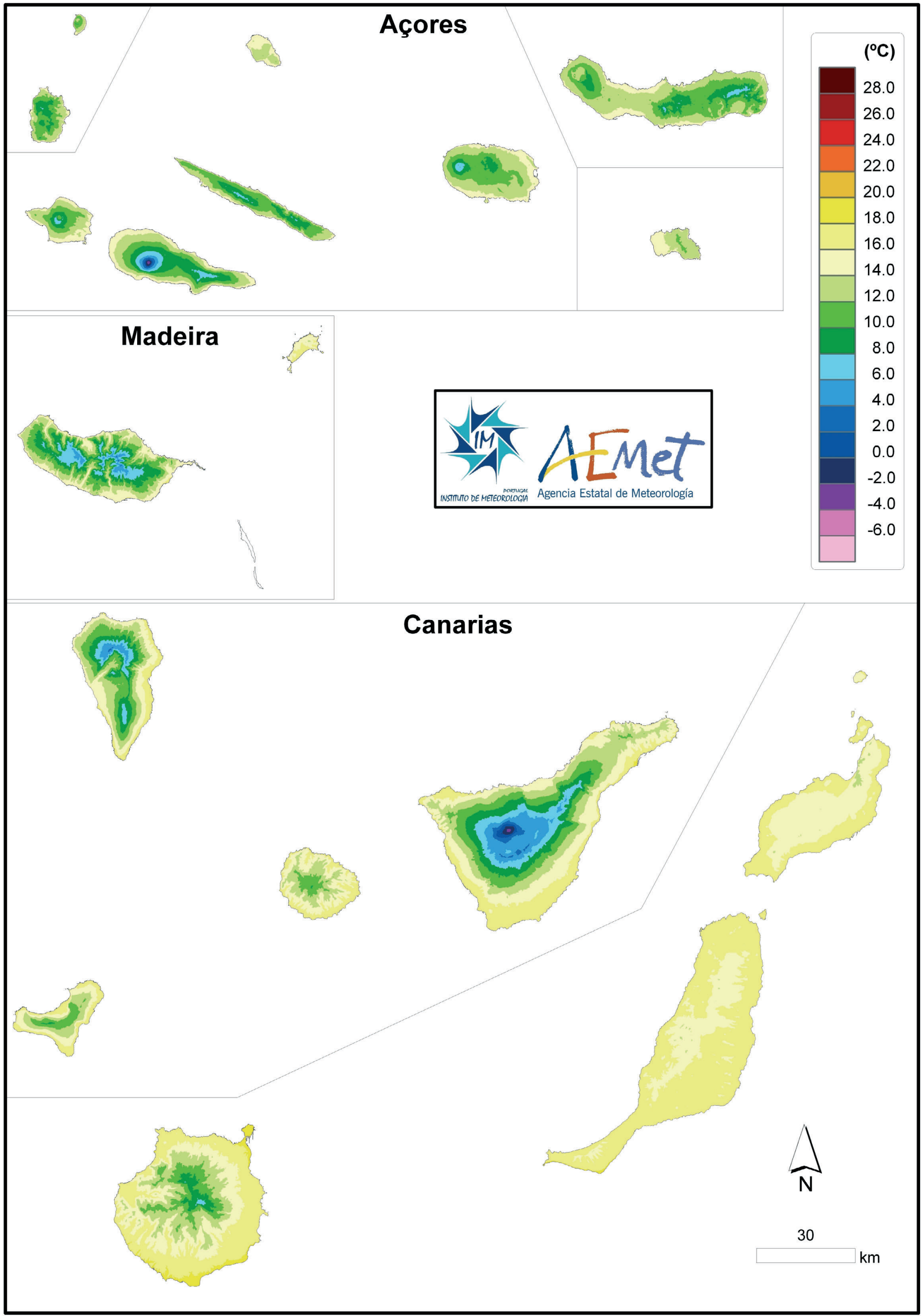

Fig. 22. Temperatura media anual de las mínimas.

Média da temperatura mínima anual.

Annual average minimum temperature. 


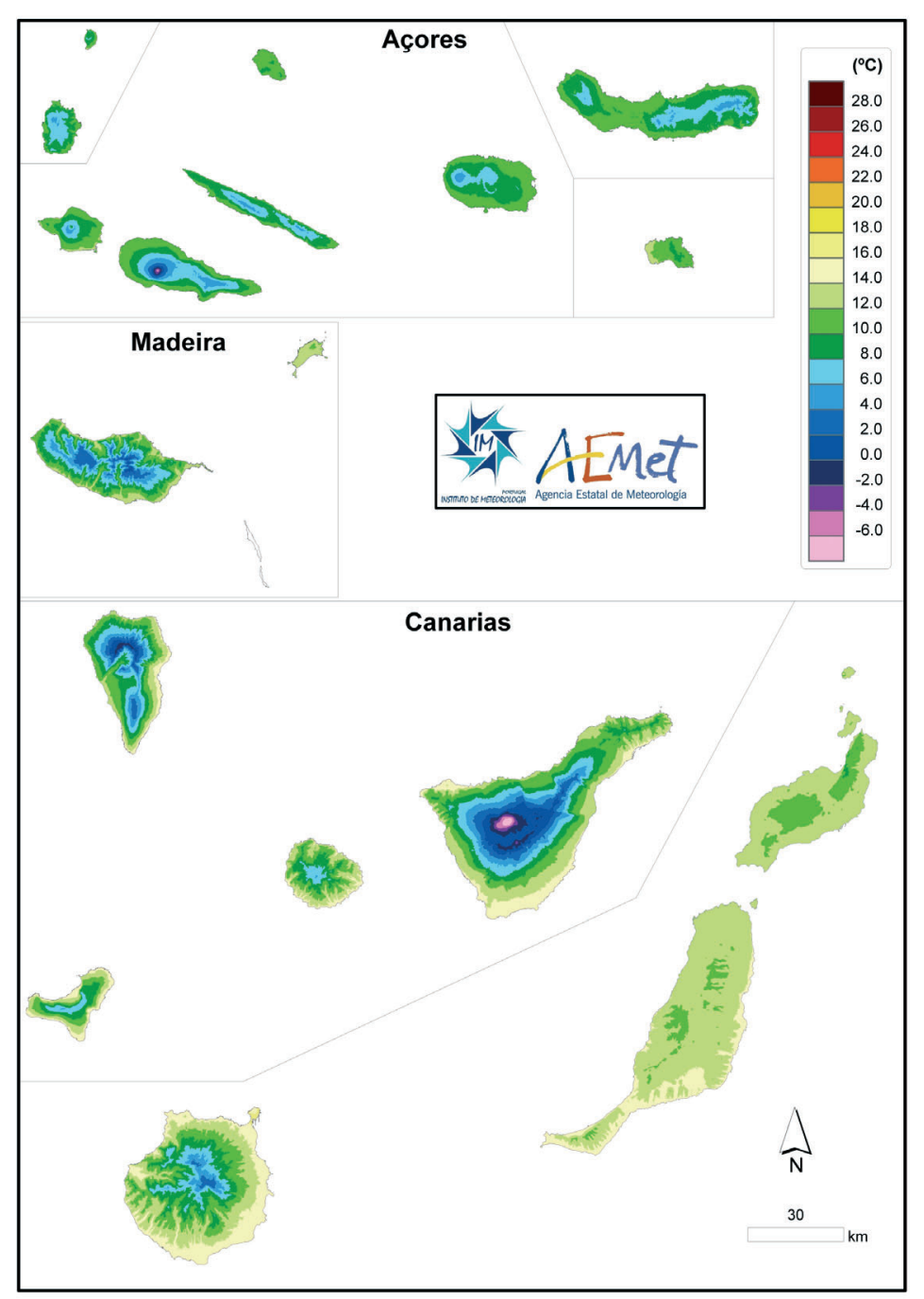

Fig. 23. Temperatura media de las mínimas de enero.

Média da temperatura mínima em Janeiro.

Average minimum temperature in January.

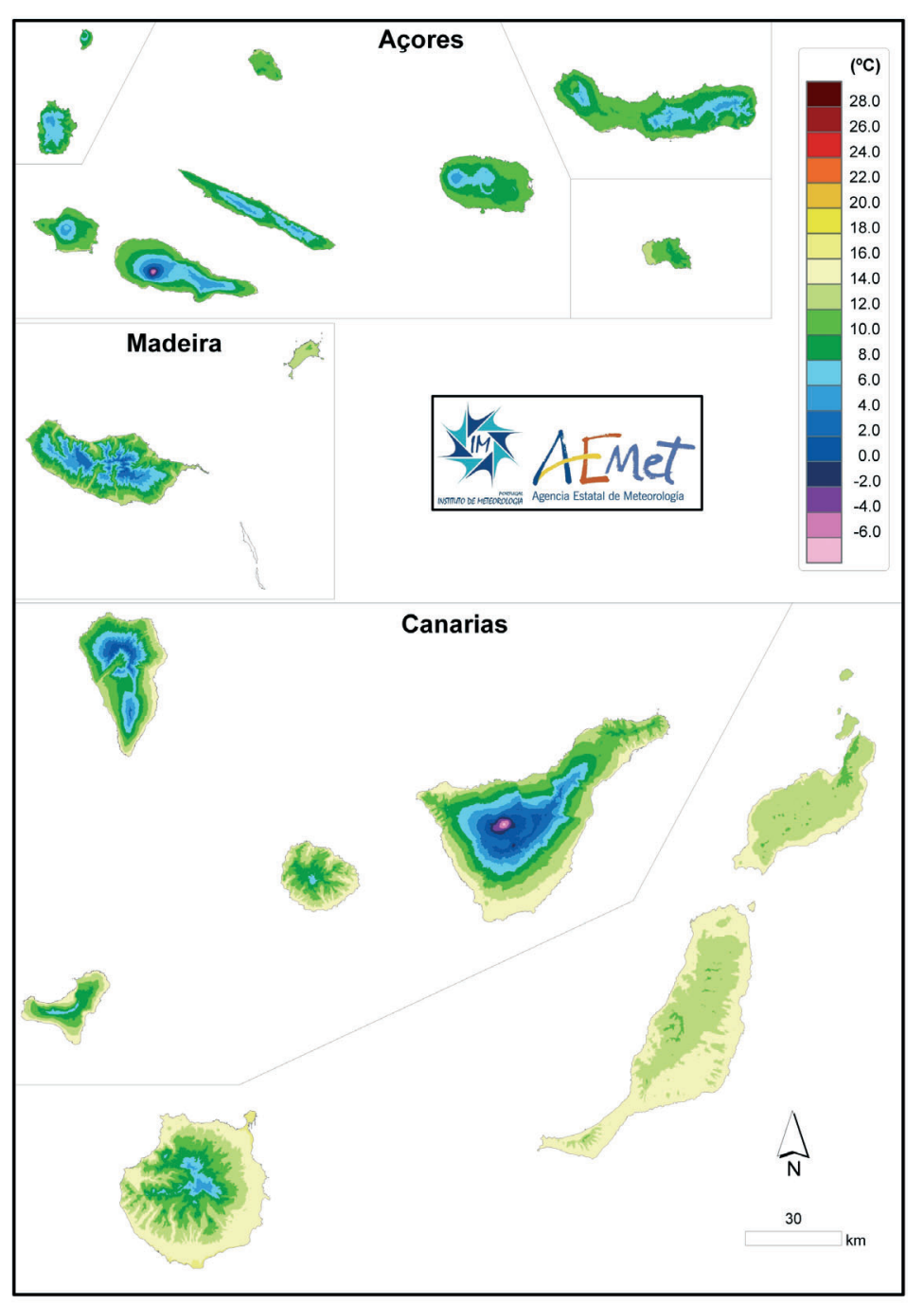

Fig. 25. Temperatura media de las mínimas de marzo.

Média da temperatura mínima em Marco.

Average minimum temperature in March.

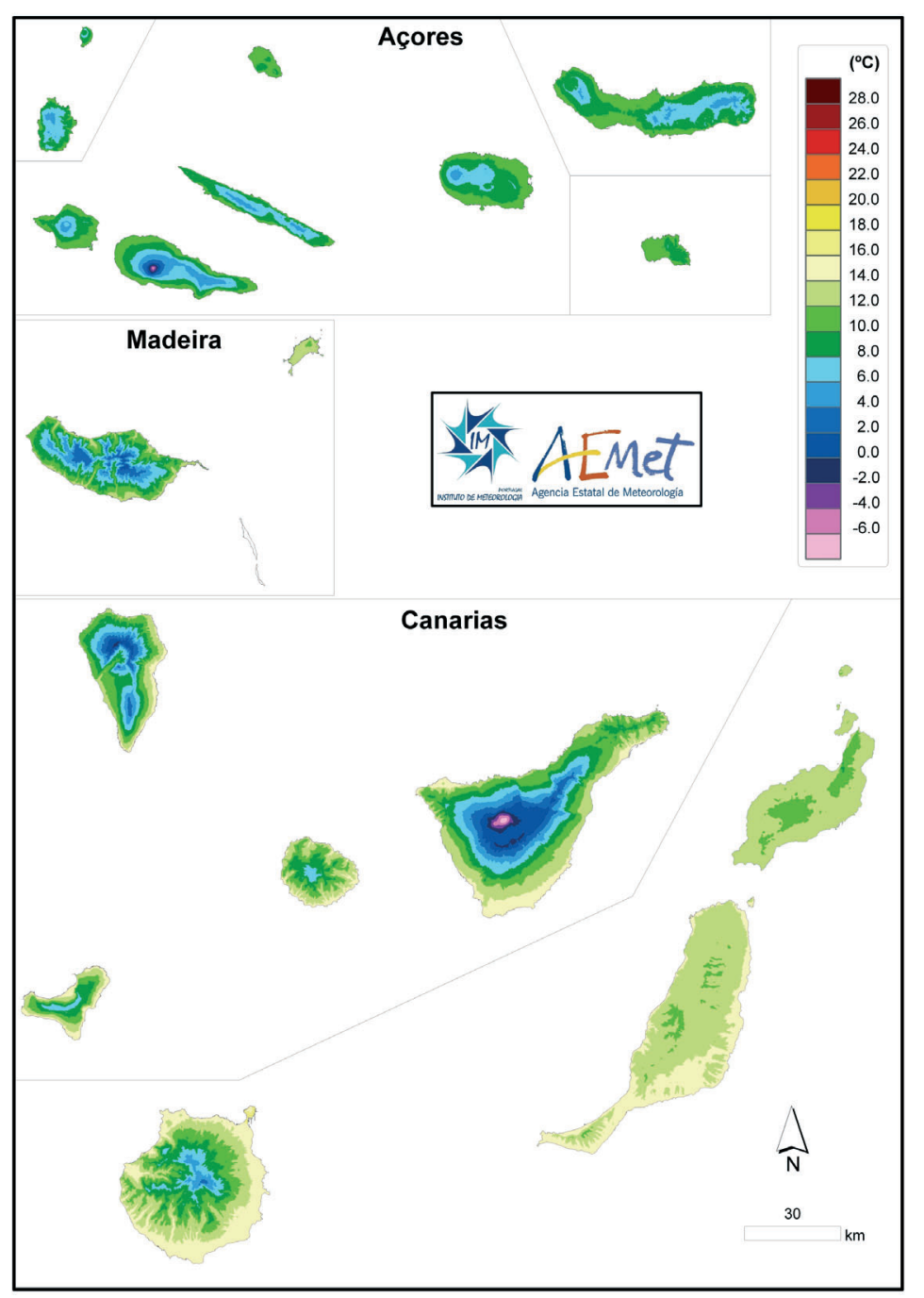

Fig. 24. Temperatura media de las mínimas de febrero.

Média da temperatura mínima em Fevereiro.

Average minimum temperature in February.

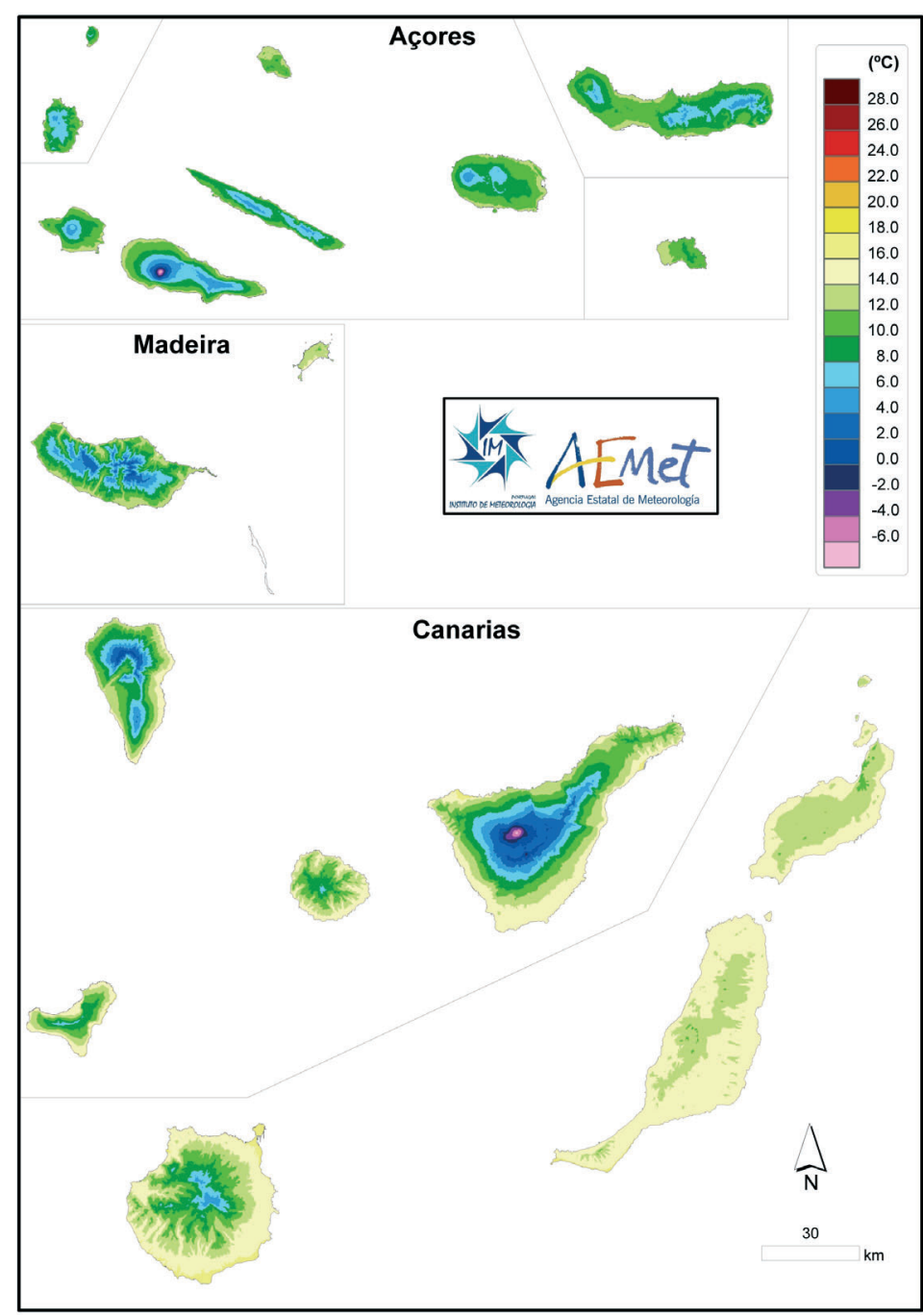

Fig. 26. Temperatura media de las mínimas de abril.

Média da temperatura mínima em Abril.

Average minimum temperature in April. 


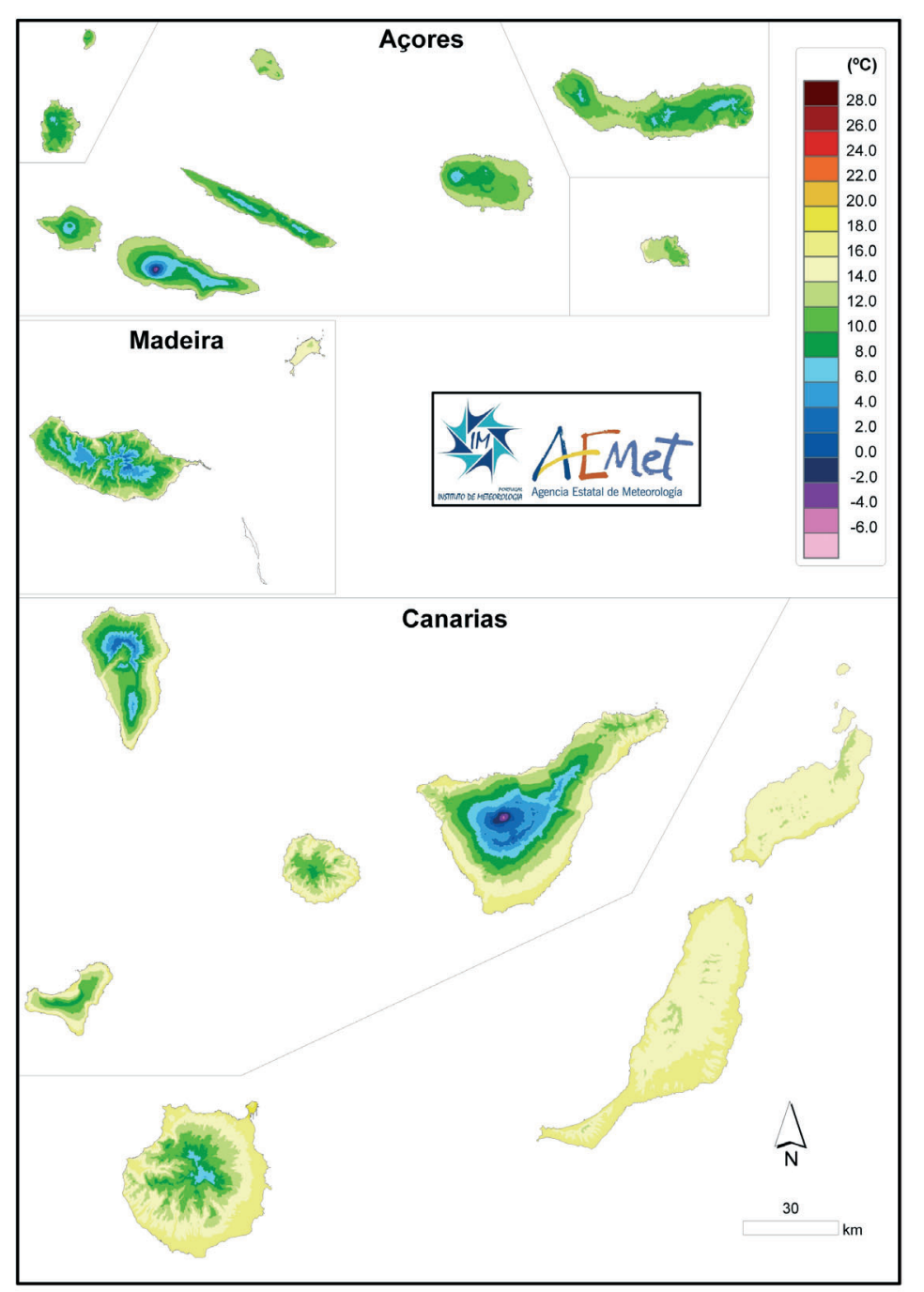

Fig. 27. Temperatura media de las mínimas de mayo.

Média da temperatura mínima em Maio.

Average minimum temperature in May.

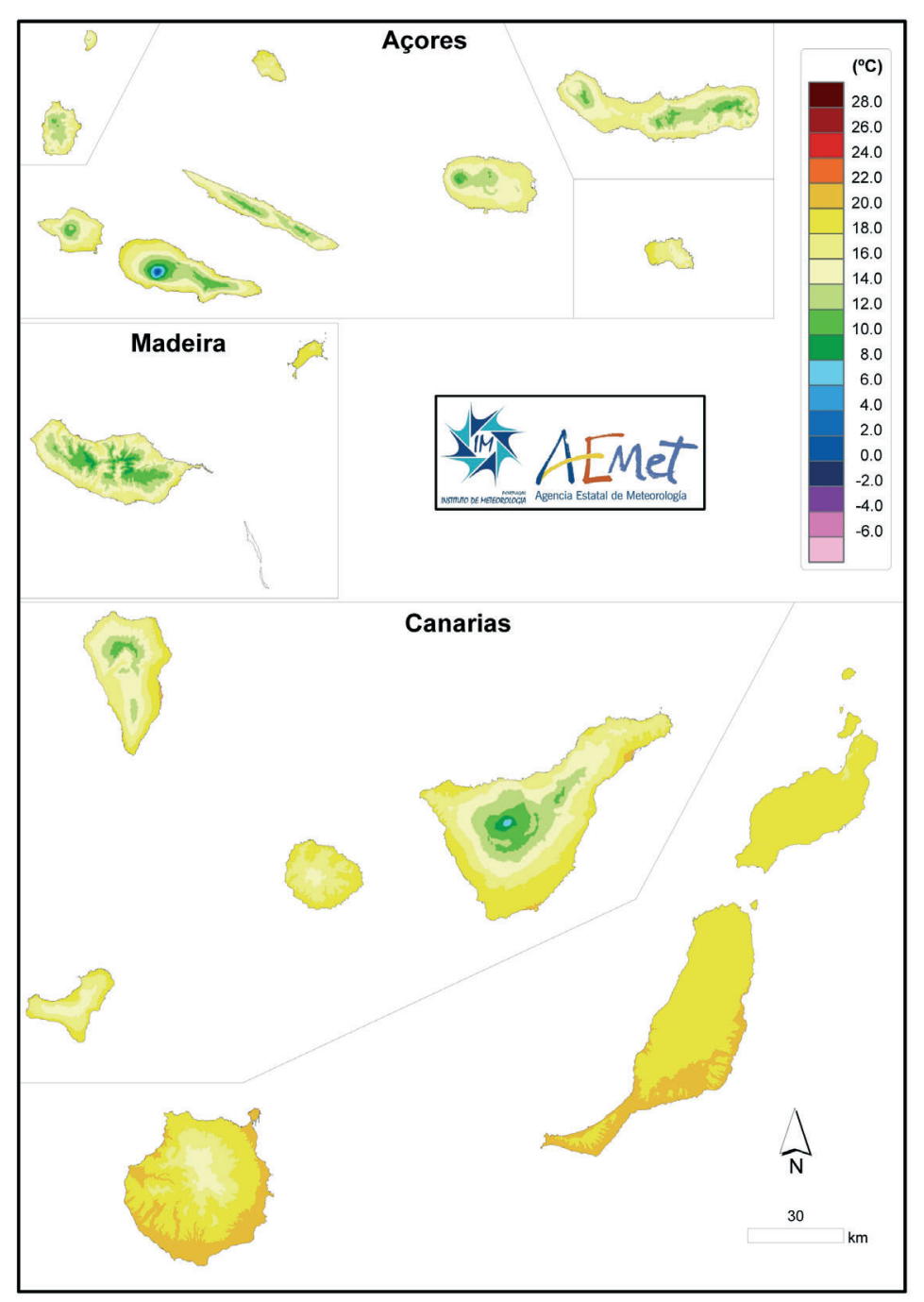

Fig. 29. Temperatura media de las mínimas de julio.

Média da temperatura mínima em Julho.

Average minimum temperature in July.

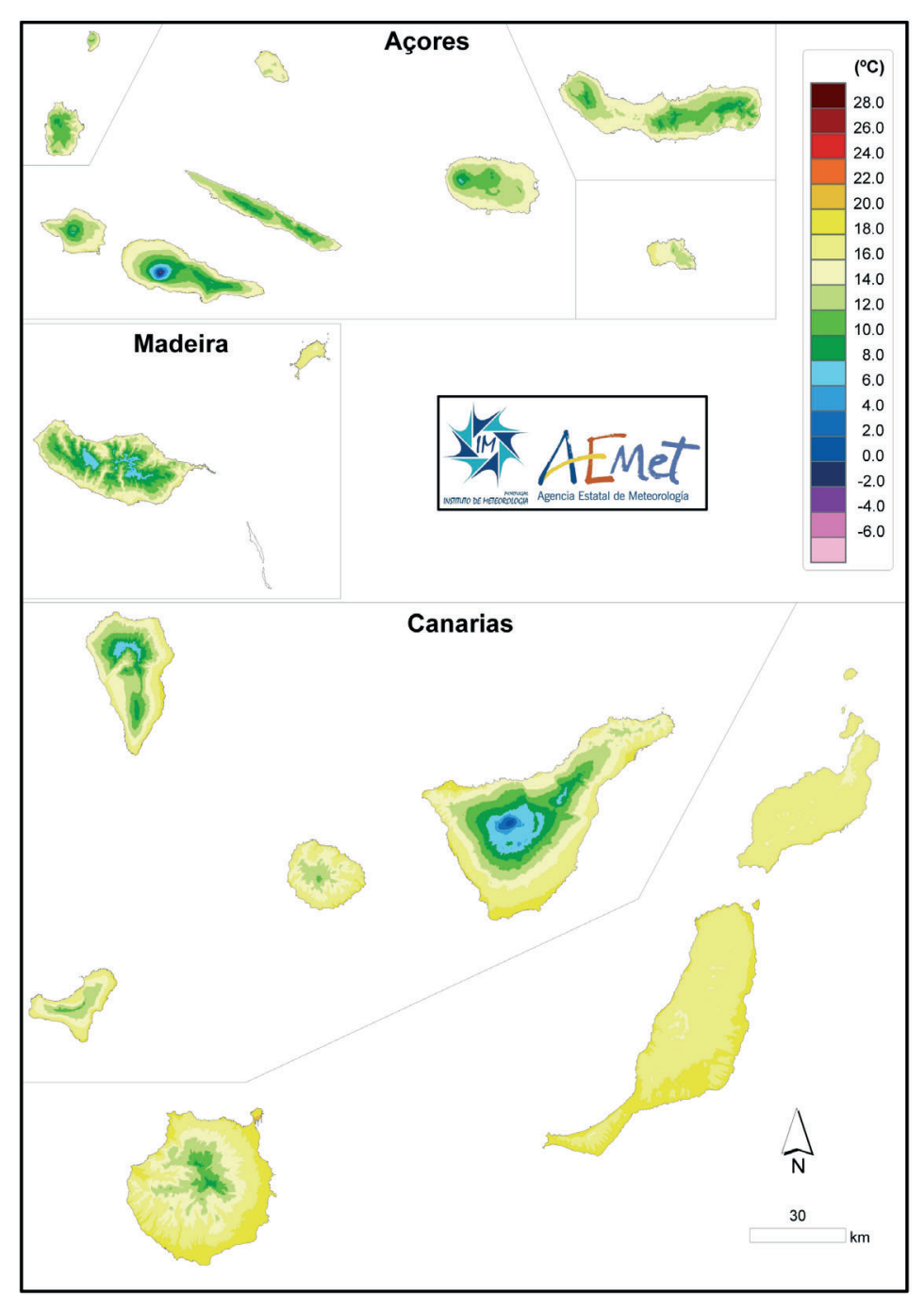

Fig. 28. Temperatura media de las mínimas de junio.

Média da temperatura mínima em Junho.

Average minimum temperature in June.

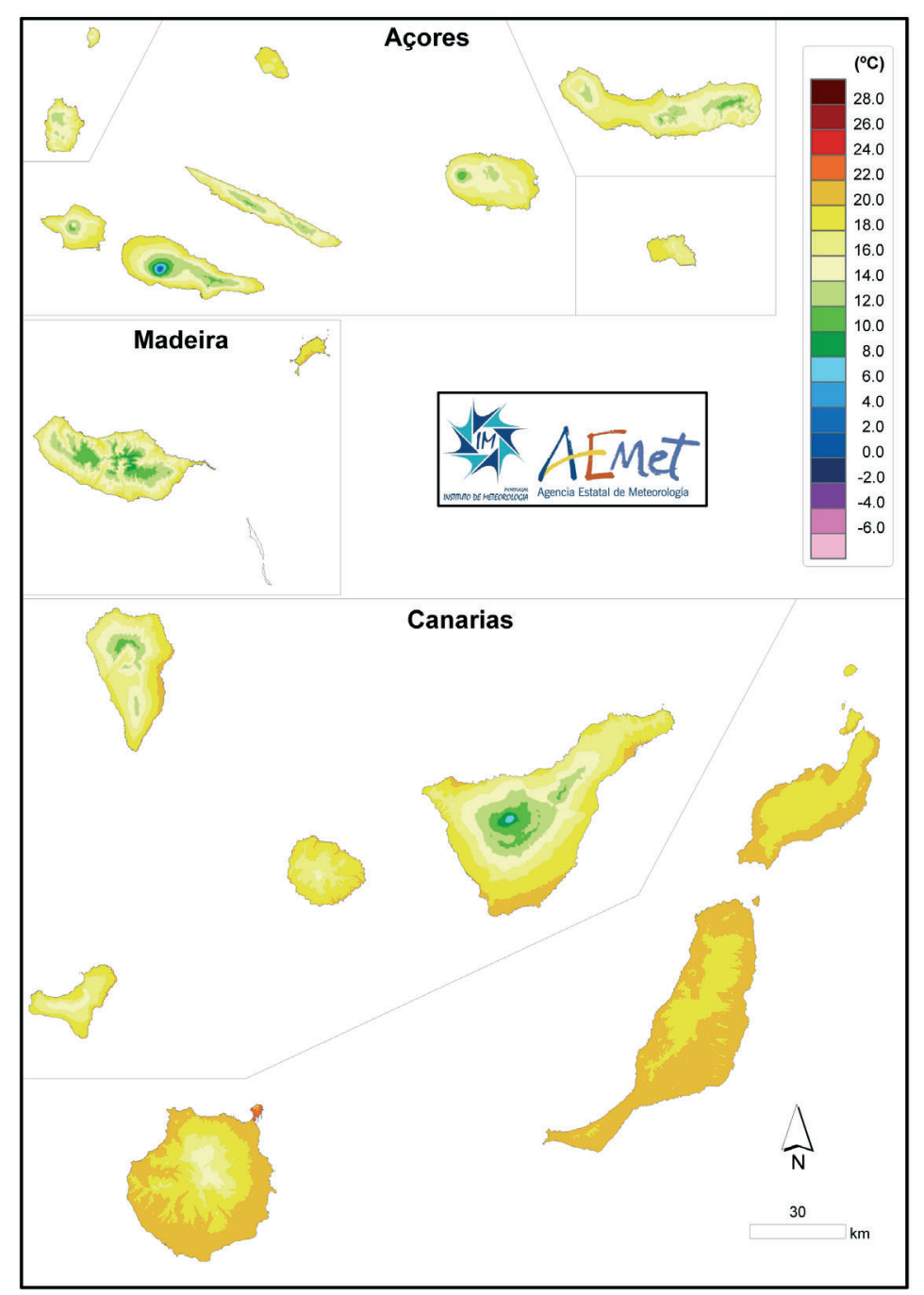

Fig. 30. Temperatura media de las mínimas de agosto.

Média da temperatura mínima em Agosto.

Average minimum temperature in August. 


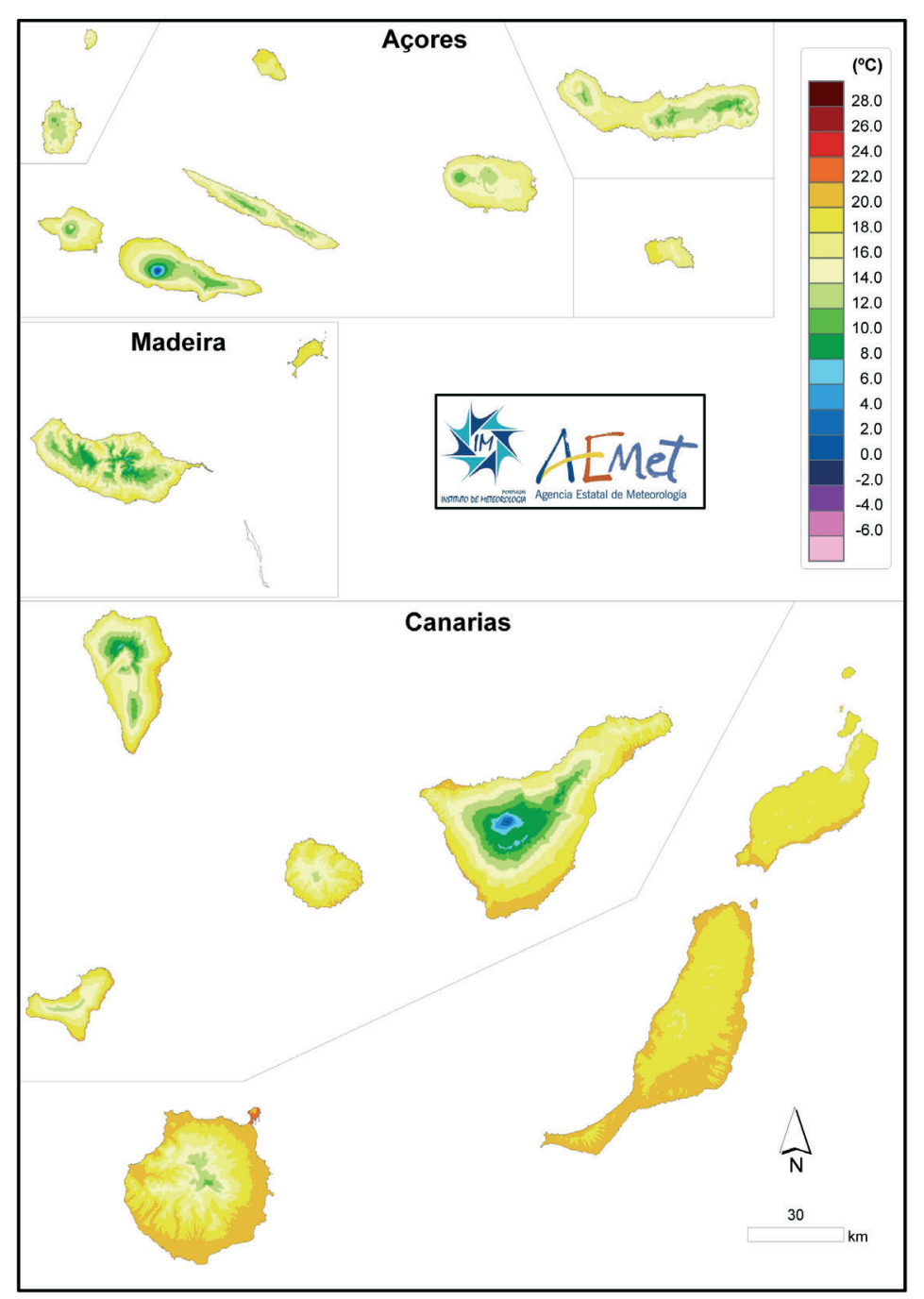

Fig. 31. Temperatura media de las mínimas de septiembre.

Média da temperatura mínima em Setembro.

Average minimum temperature in September.

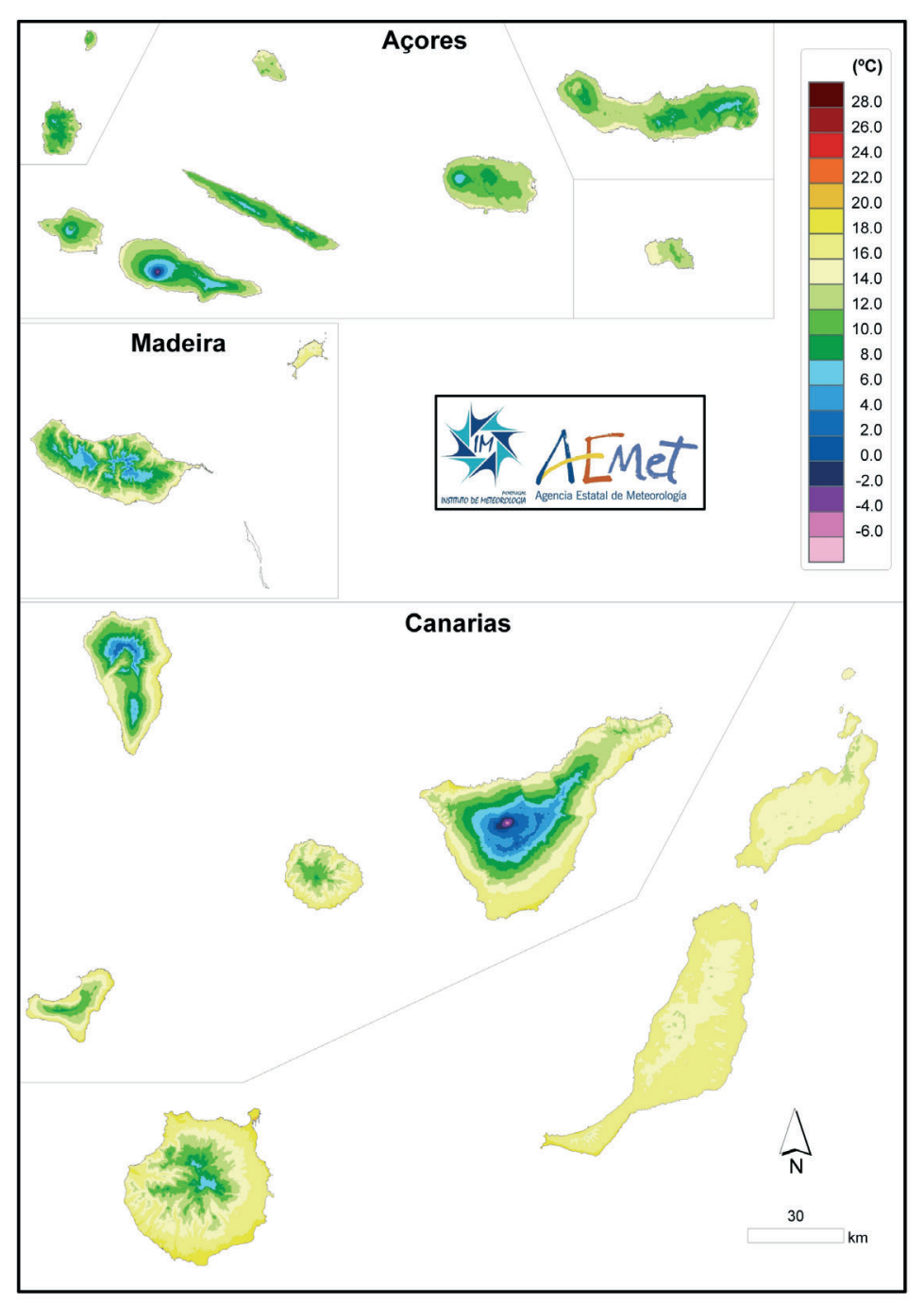

Fig. 33. Temperatura media de las mínimas de noviembre.

Média da temperatura mínima em Novembro.

Average minimum temperature in November.

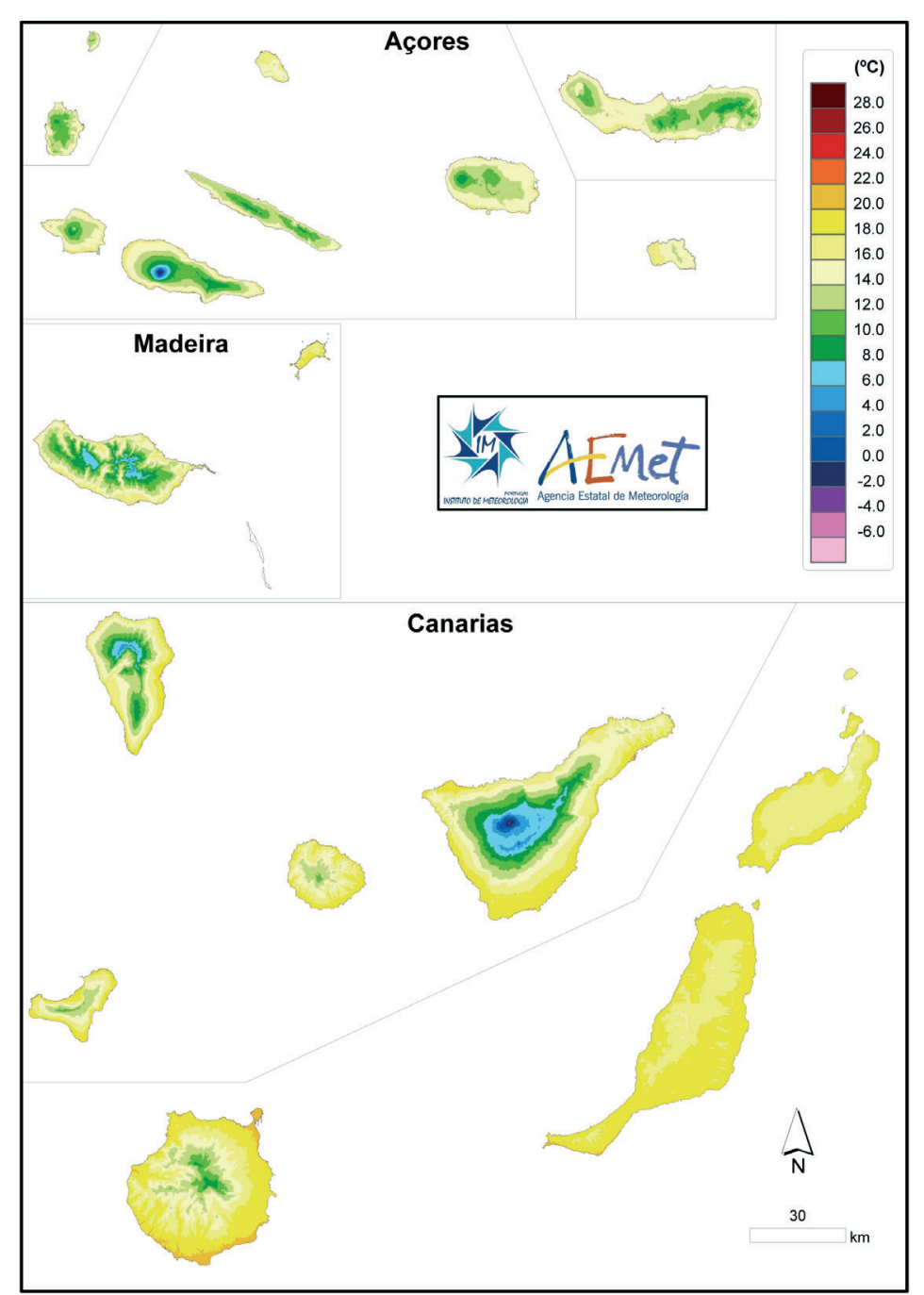

Fig. 32. Temperatura media de las mínimas de octubre.

Média da temperatura mínima em Outobro.

Average minimum temperature in October.

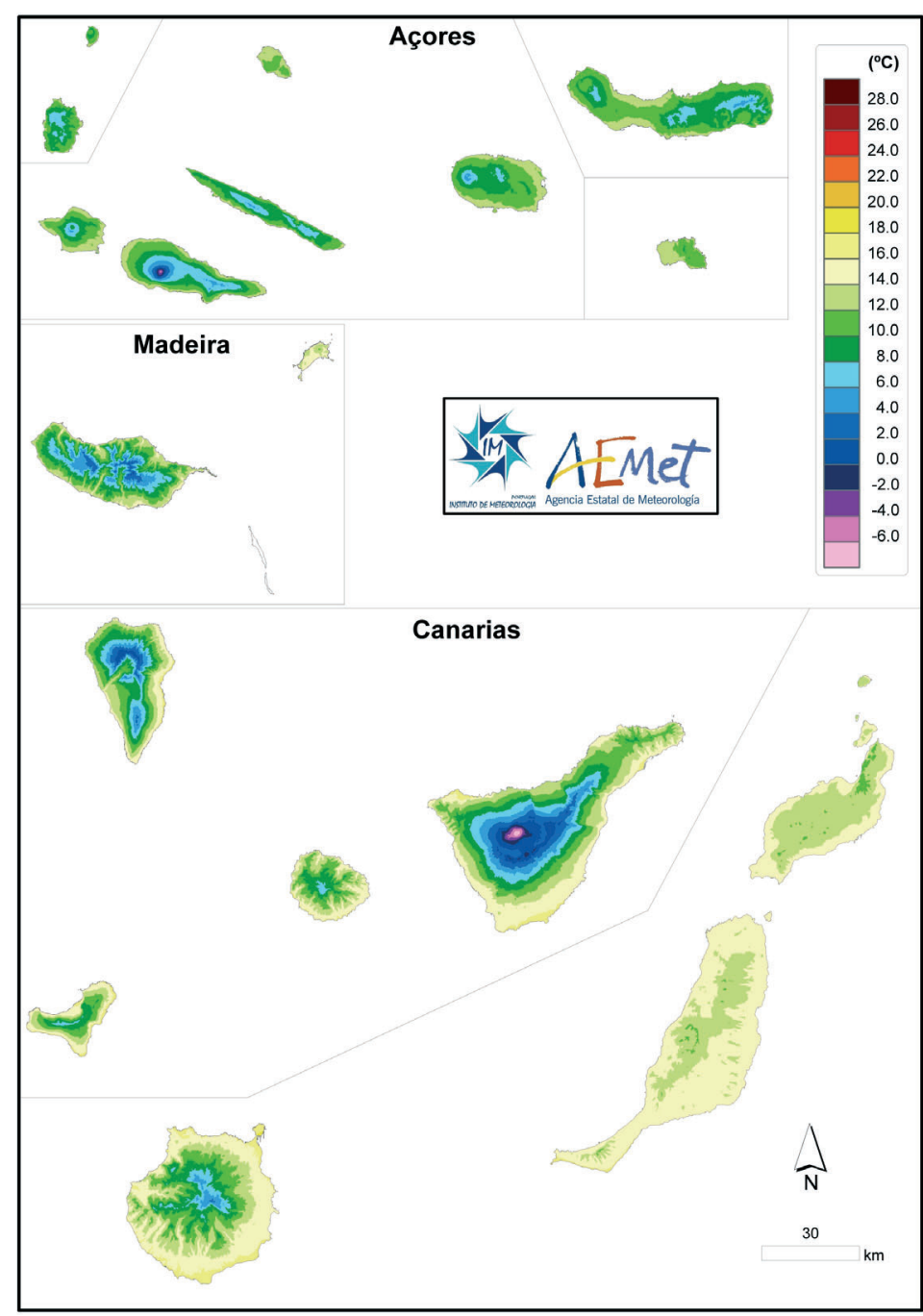

Fig. 34. Temperatura media de las mínimas de diciembre.

Média da temperatura mínima em Dezembro.

Average minimum temperature in December. 


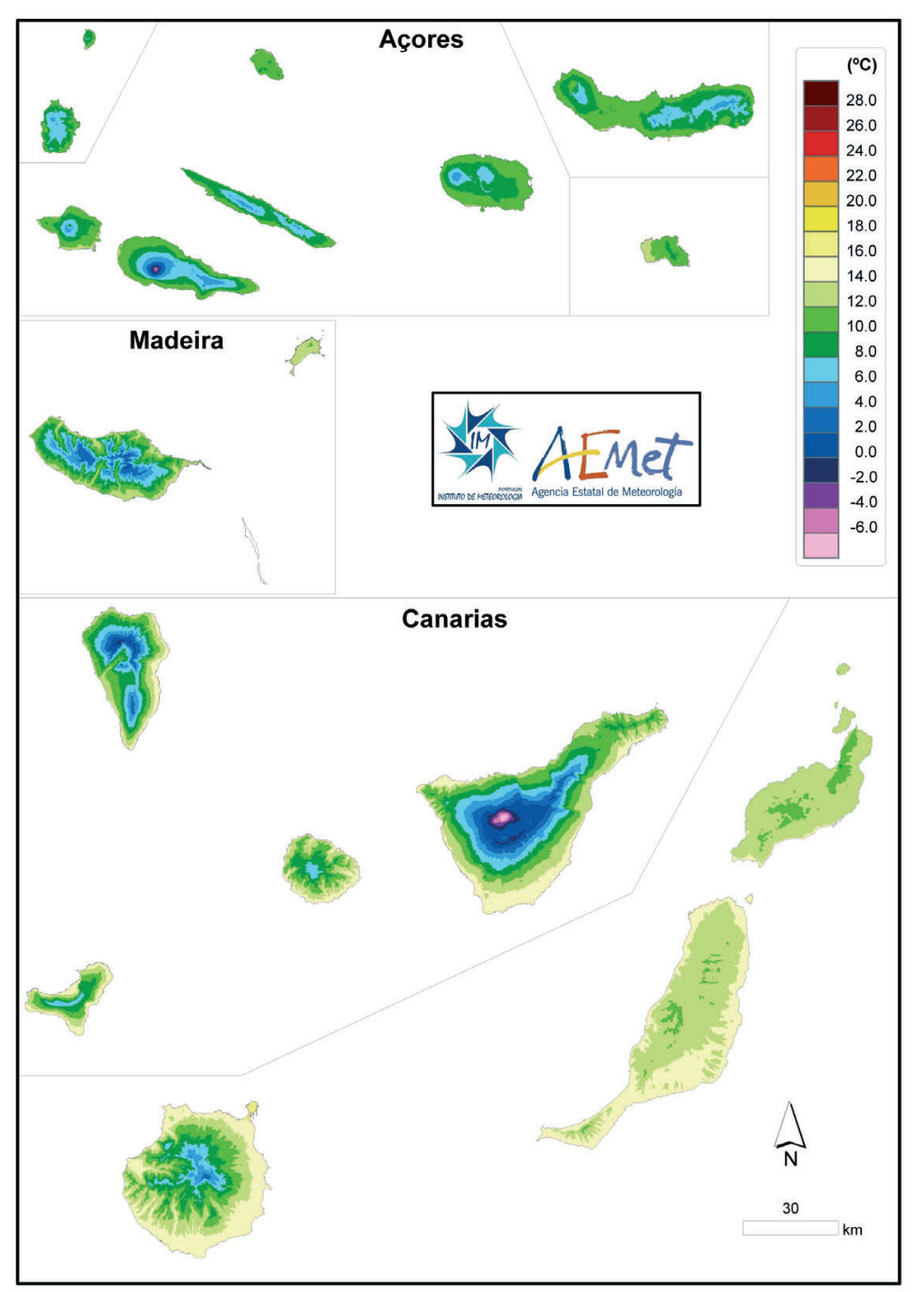

Fig. 35. Temperatura media de las mínimas en invierno.

Média da temperatura mínima no Inverno.

Average minimum temperature in winter.

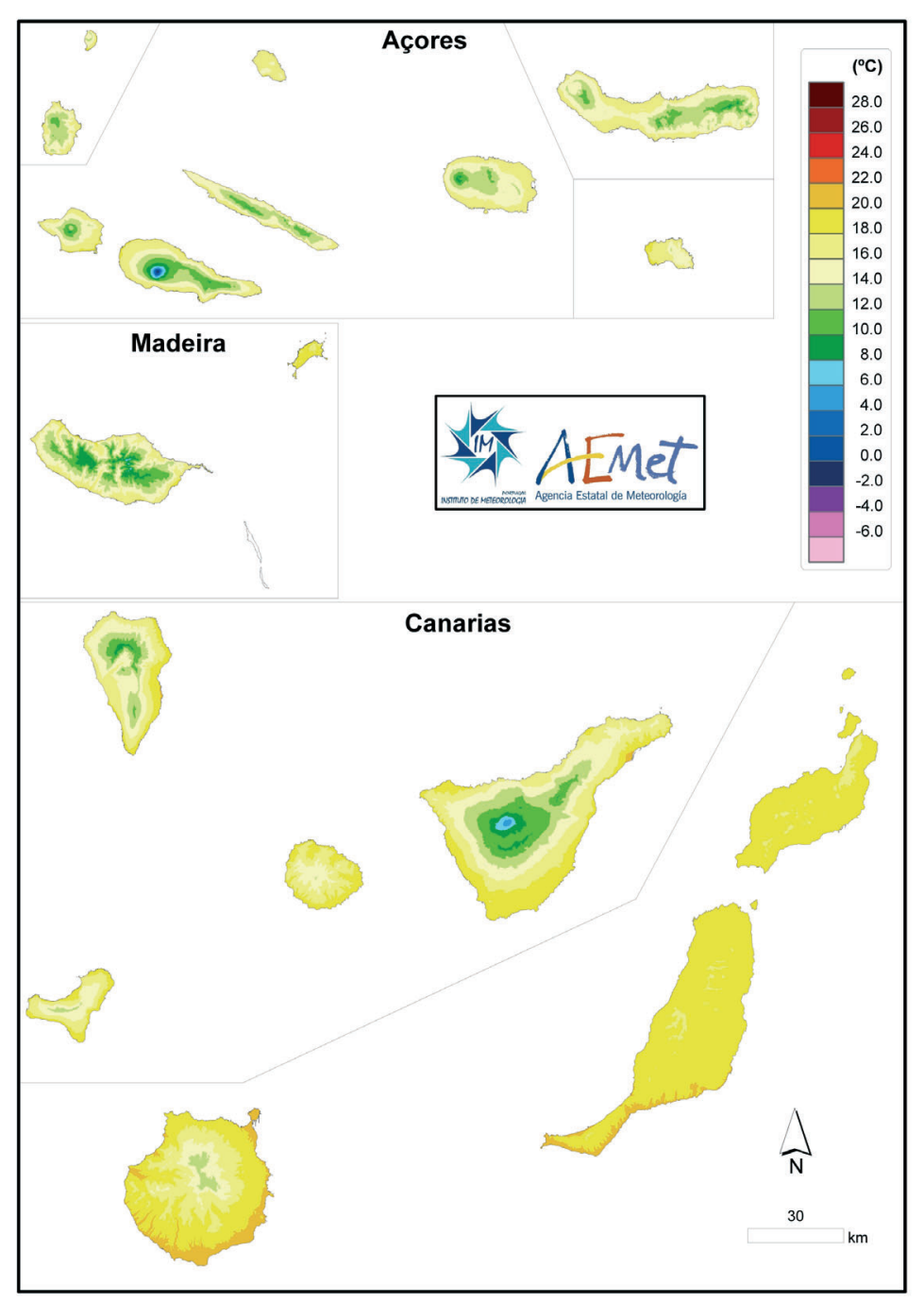

Fig. 37. Temperatura media de las mínimas en verano.

Média da temperatura mínima no Verão.

Average minimum temperature in summer.

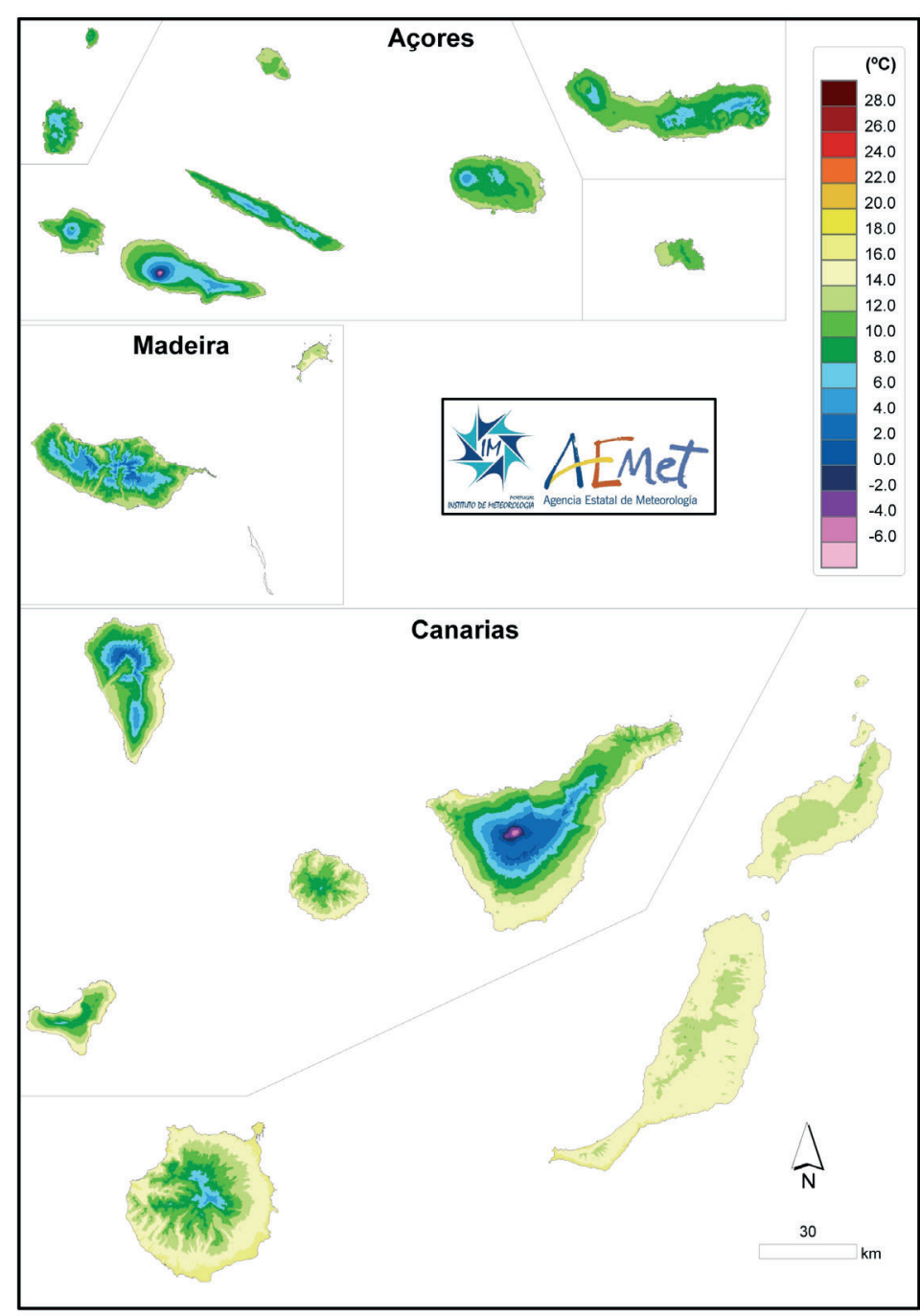

Fig. 36. Temperatura media de las mínimas en primavera.

Média da temperatura mínima na Primavera.

Average minimum temperature in spring.

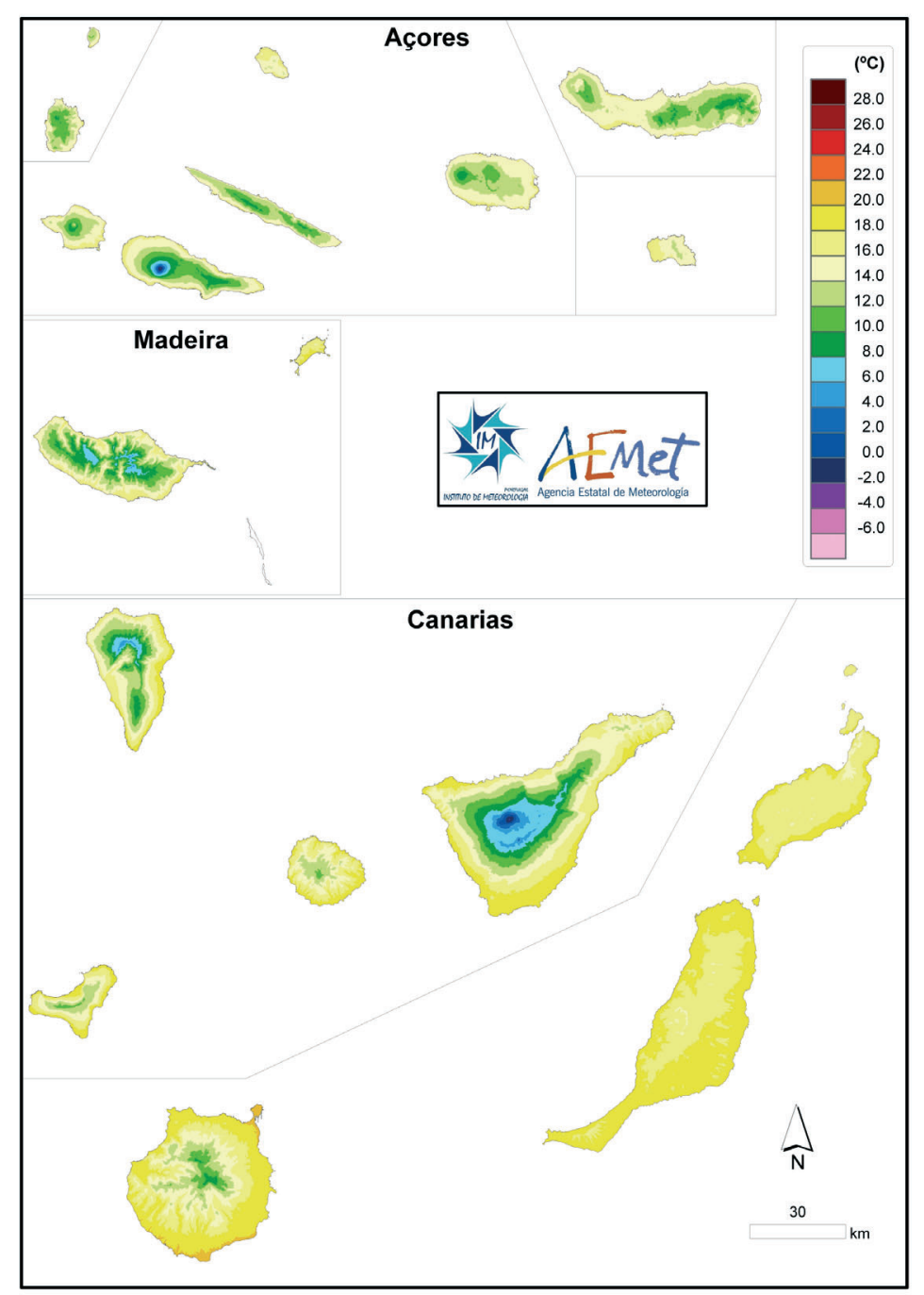

Fig. 38. Temperatura media de las mínimas de otoño.

Média da temperatura mínima em Outono.

Average minimum temperature in autumn. 
Temperatura media de las máximas en los archipiélagos de Canarias, Madeira y Azores (1971-2000) /

Média da temperatura máxima do ar nos arquipélagos das Canárias, da Madeira e dos Açores (1971-2000) / Average maximum air temperature in the archipelagos of the Canary Islands, Madeira and the Azores (1971-2000)

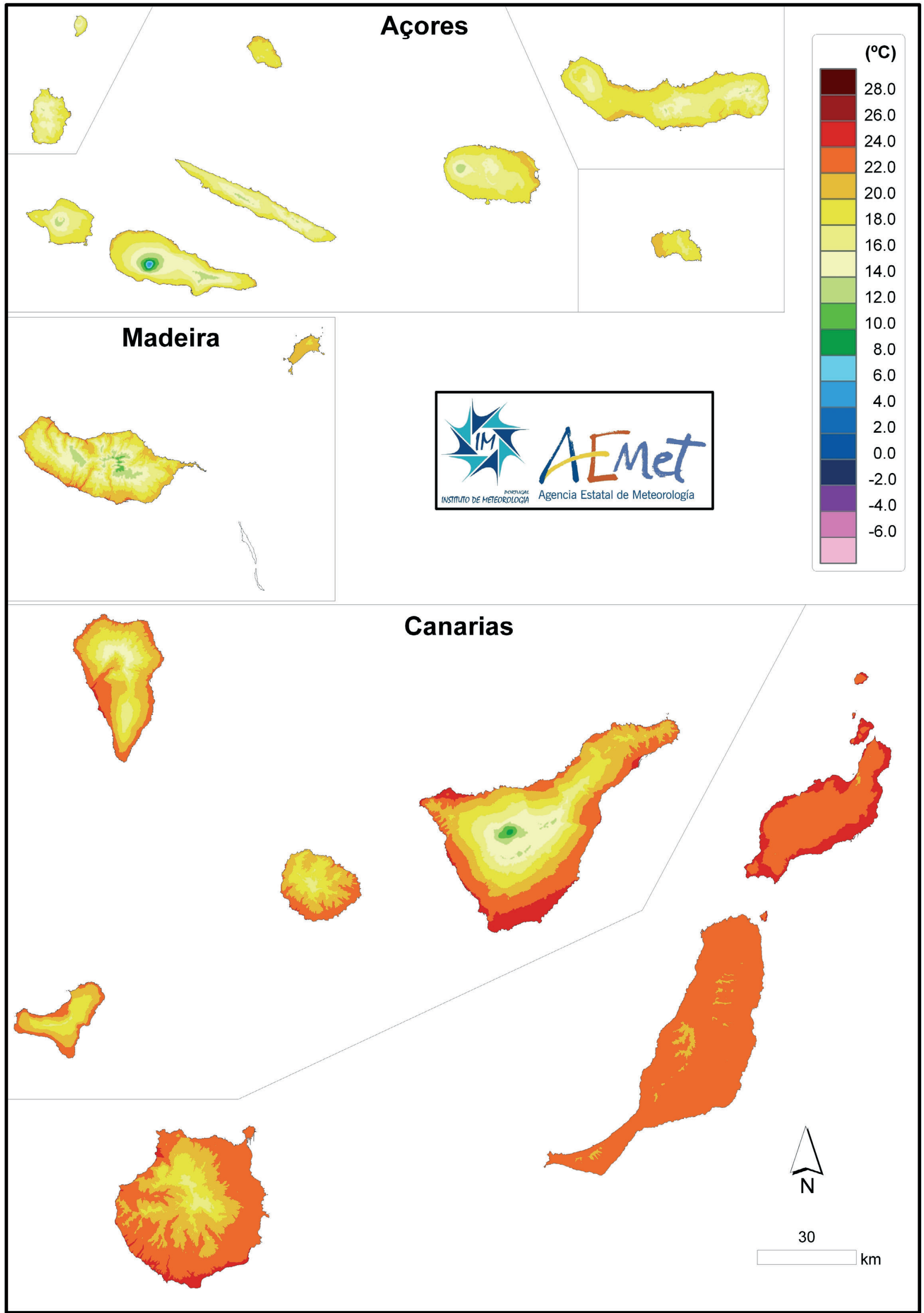

Fig. 39. Temperatura media anual de las máximas.

Média da temperatura máxima anual.

Annual average maximum temperature. 


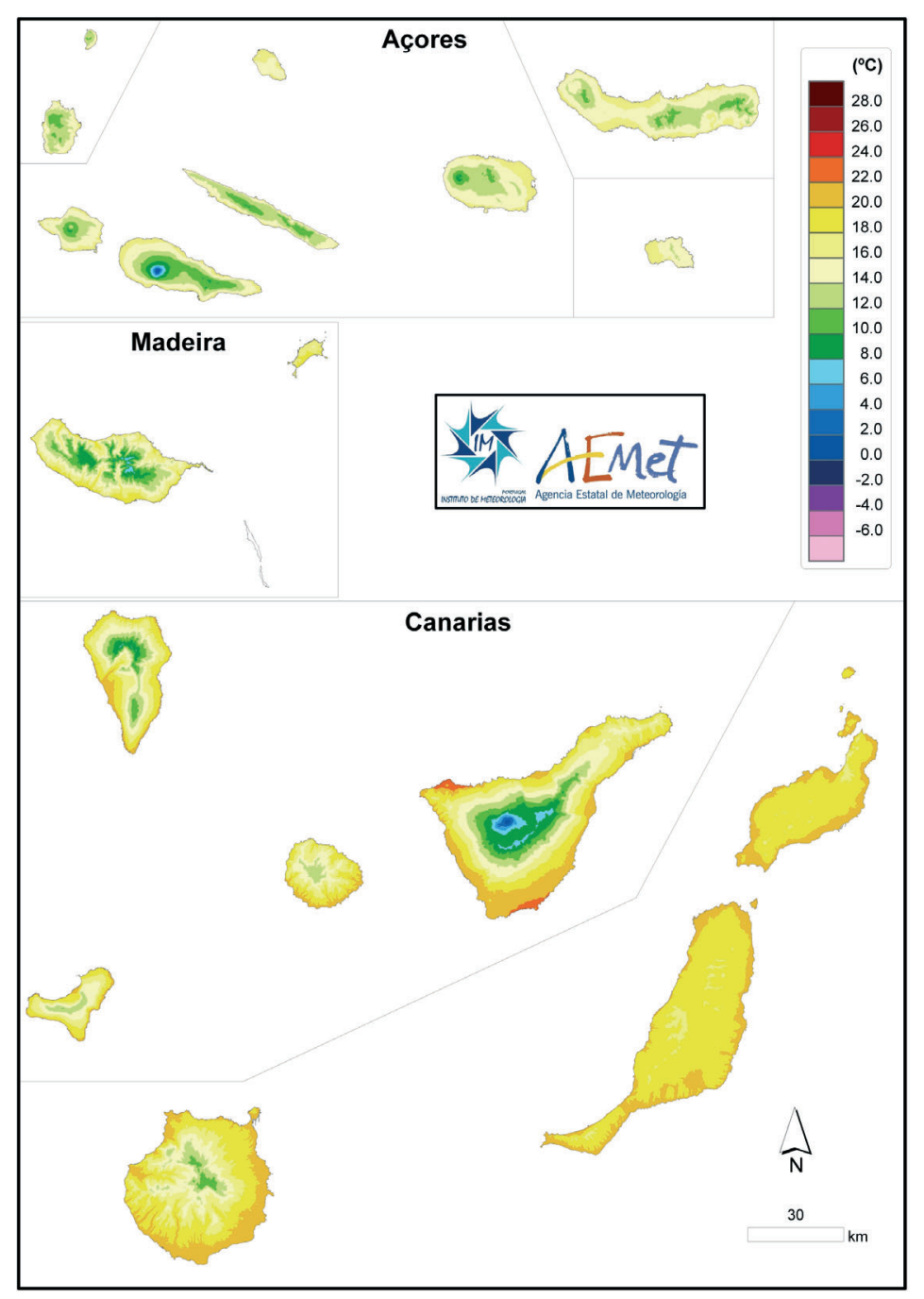

Fig. 40. Temperatura media de las máximas de enero.

Média da temperatura máxima em Janeiro.

Average maximum temperature in January.

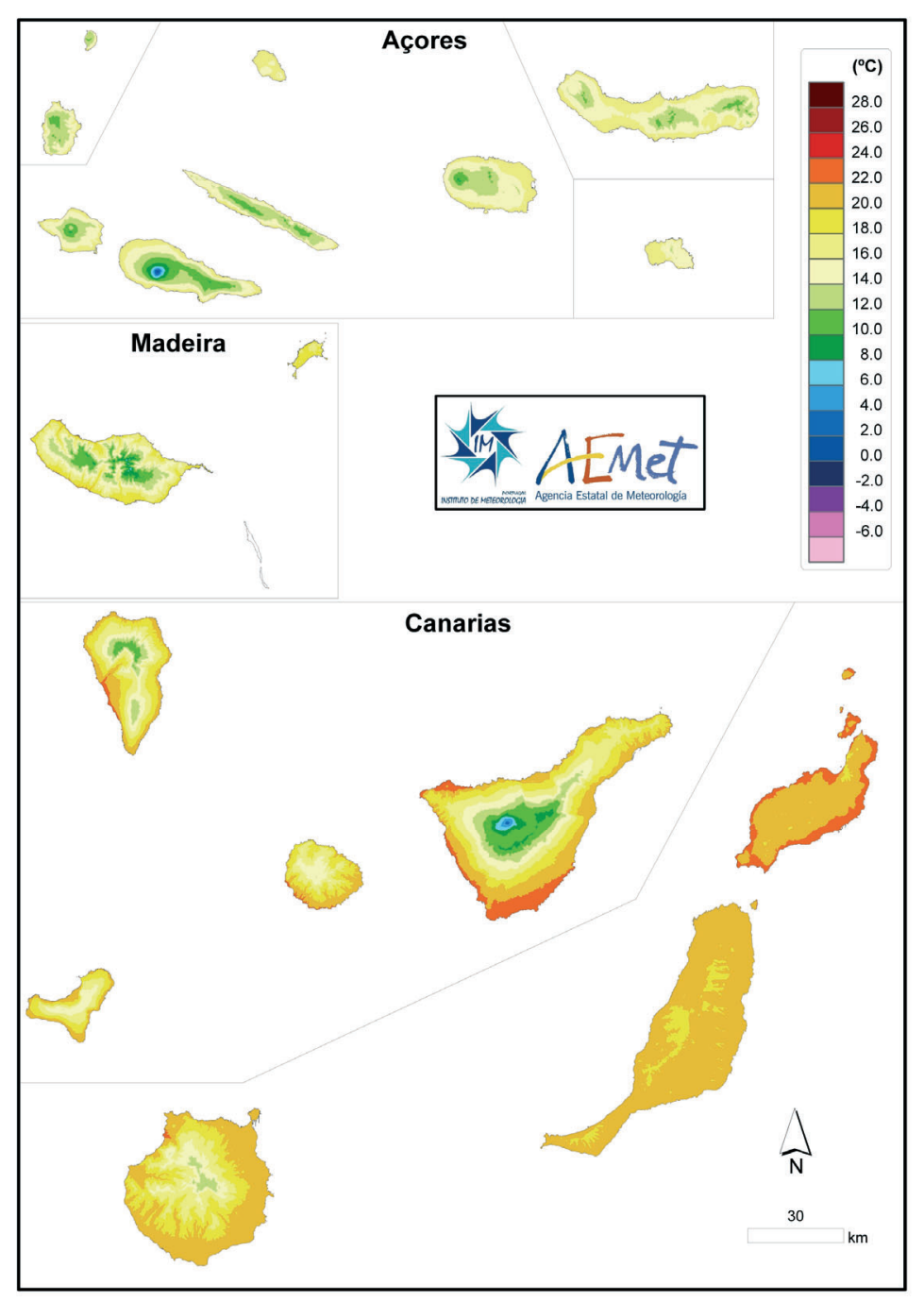

Fig. 42. Temperatura media de las máximas de marzo.

Média da temperatura máxima em Março.

Average maximum temperature in March.

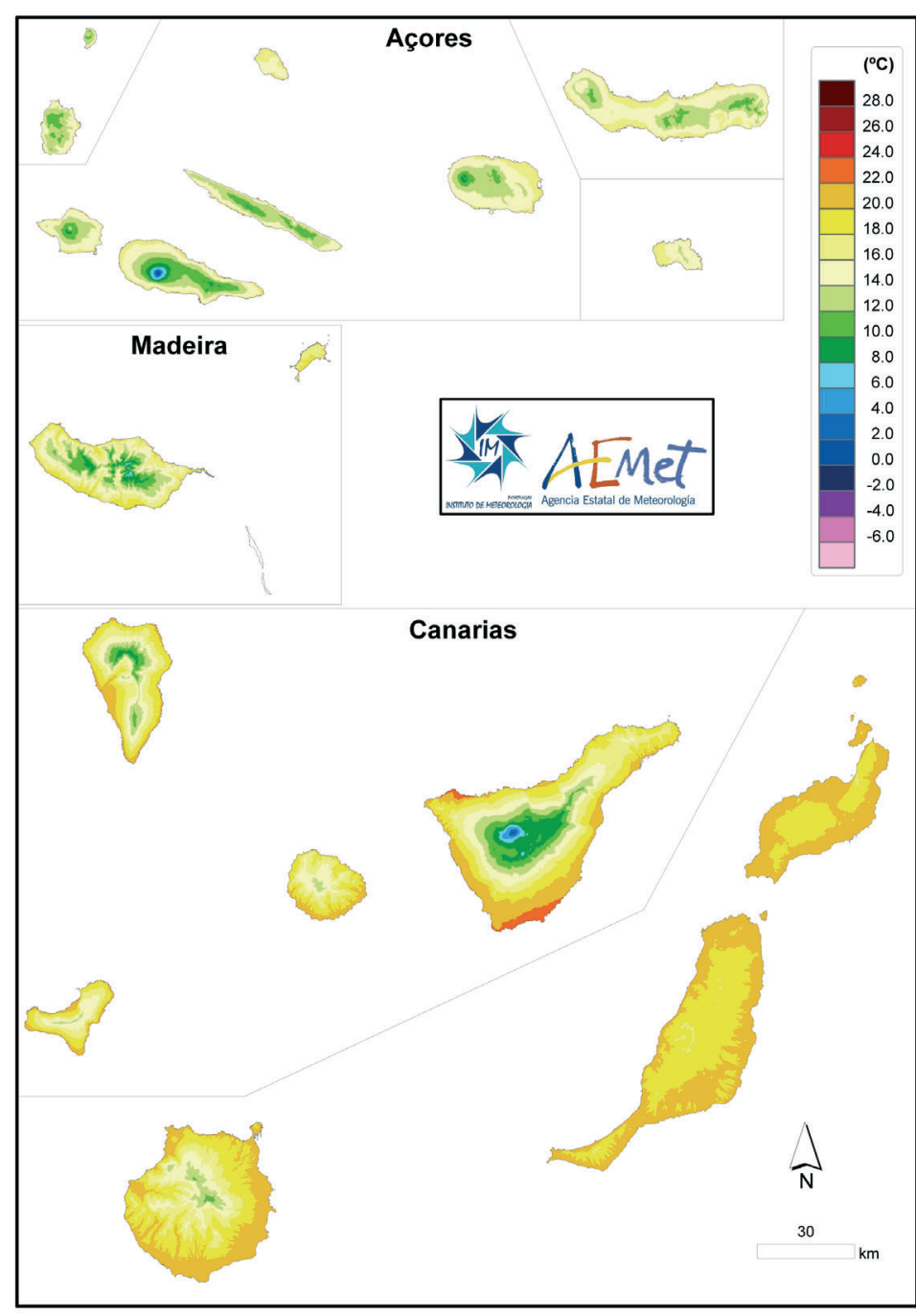

Fig. 41. Temperatura media de las máximas de febrero.

Média da temperatura máxima em Fevereiro.

Average maximum temperature in February.

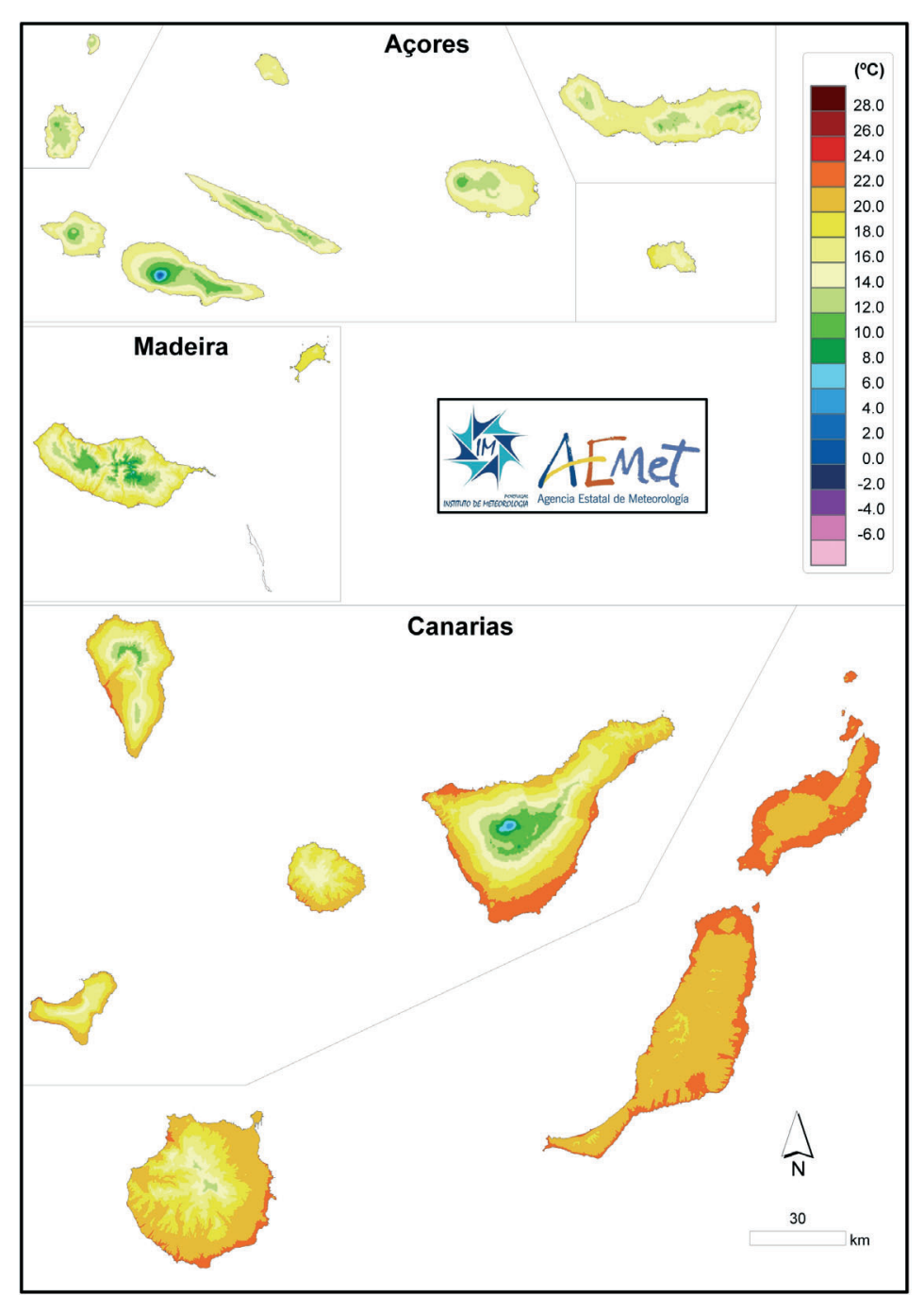

Fig. 43. Temperatura media de las máximas de abril.

Média da temperatura máxima em Abril.

Average maximum temperature in April. 


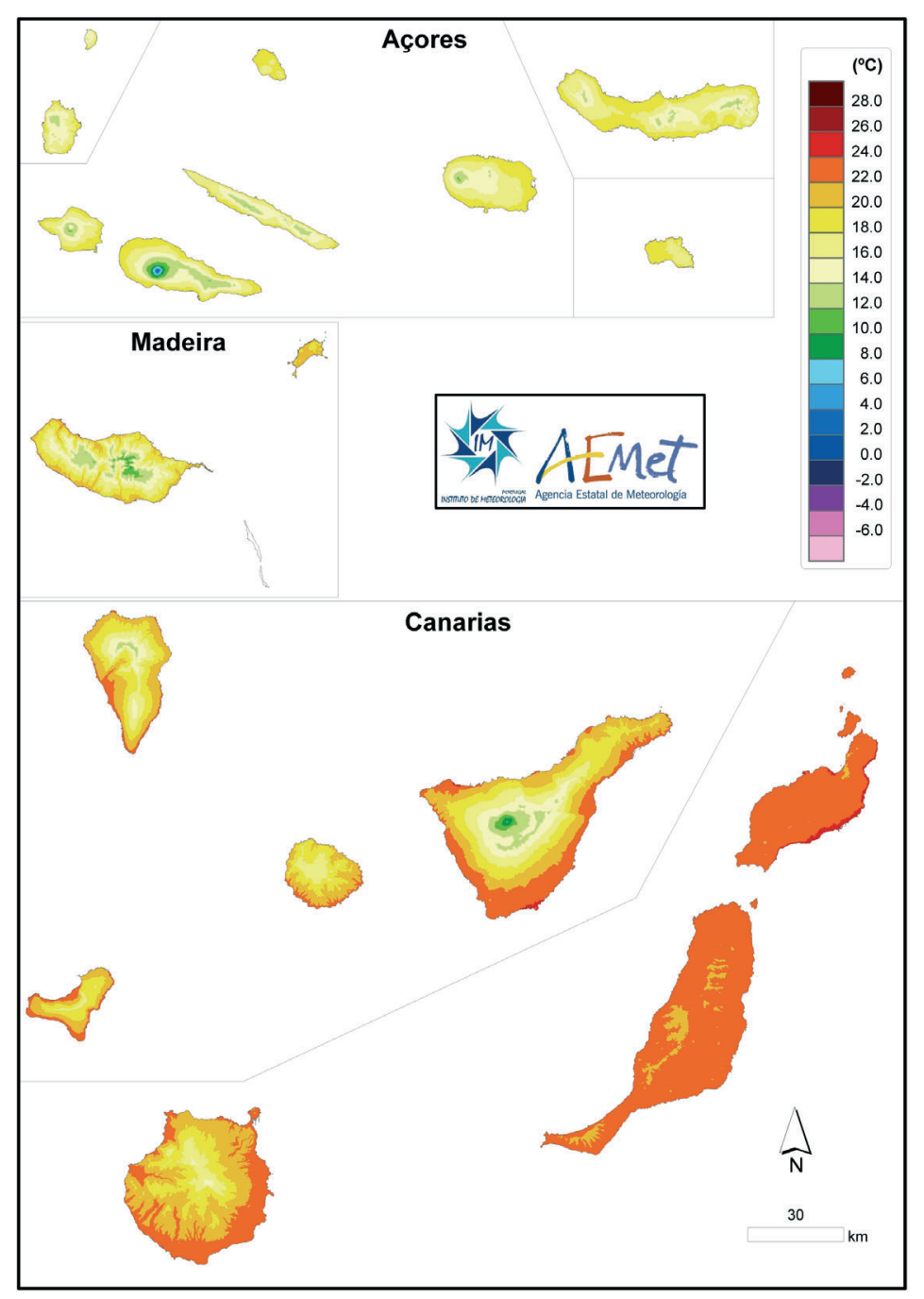

Fig. 44. Temperatura media de las máximas de mayo.

Média da temperatura máxima em Maio.

Average maximum temperature in May.

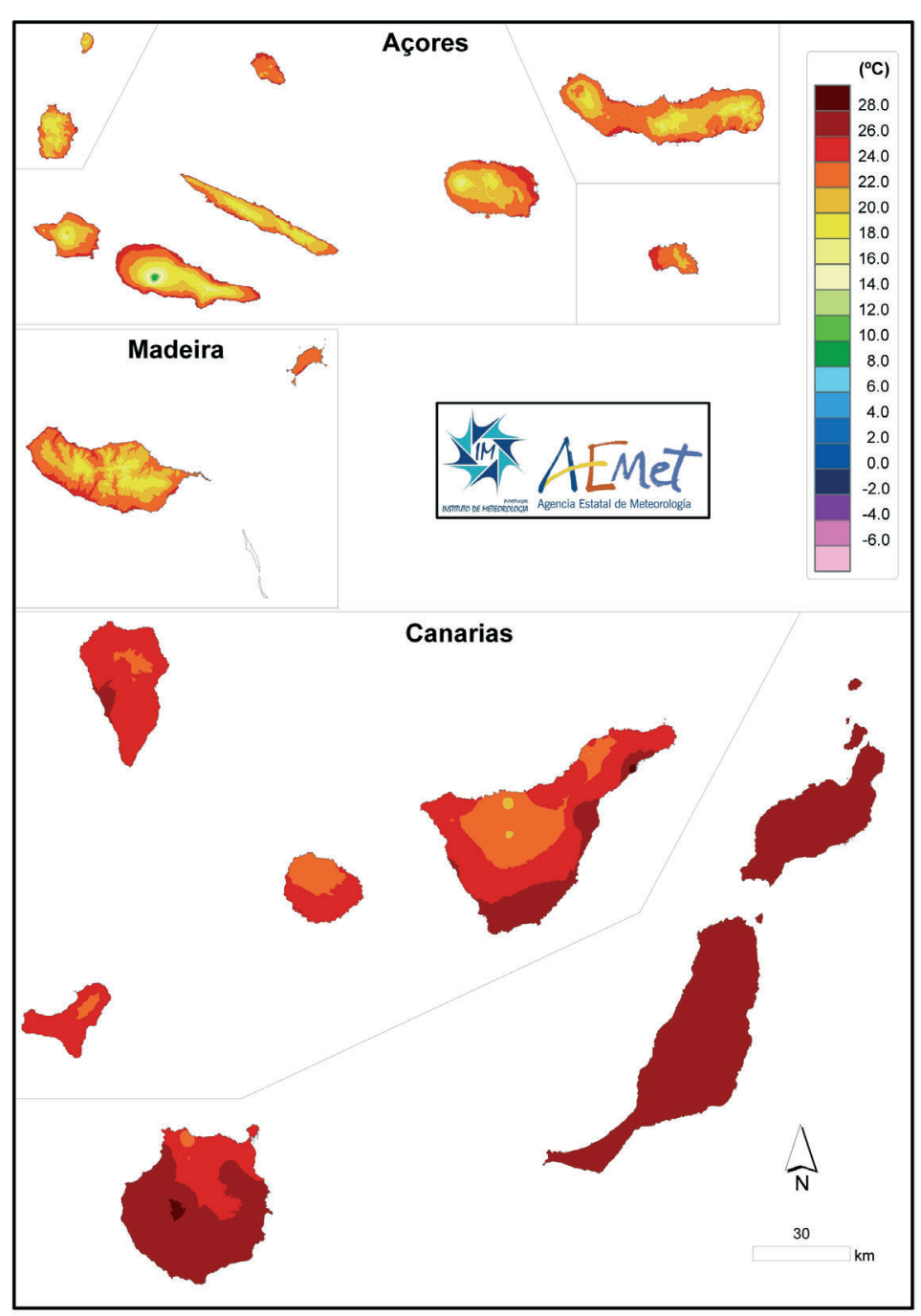

Fig. 46. Temperatura media de las máximas de julio.

Média da temperatura máxima em Julho.

Average maximum temperature in July.

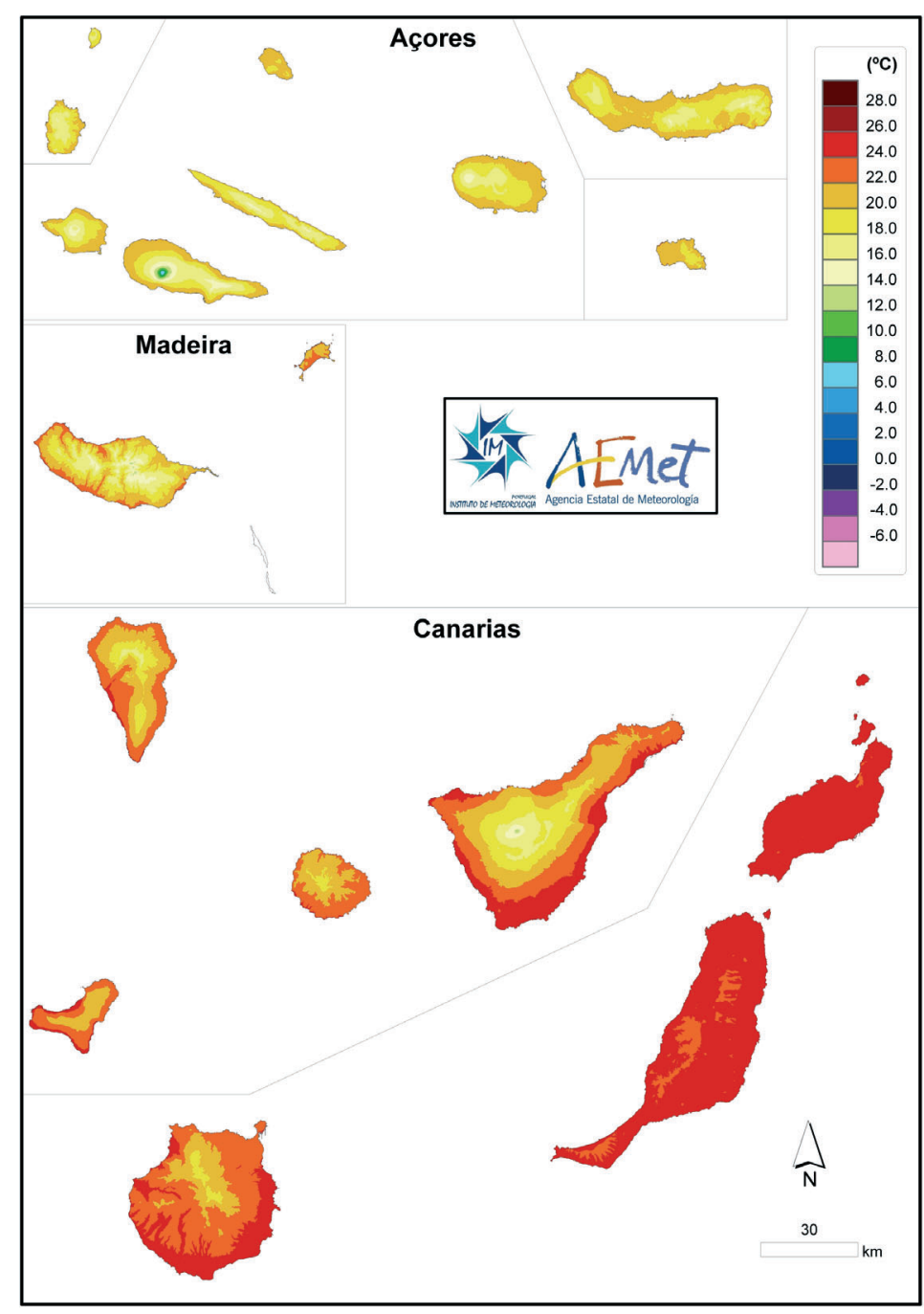

Fig. 45. Temperatura media de las máximas de junio.

Média da temperatura máxima em Junho.

Average maximum temperature in June.

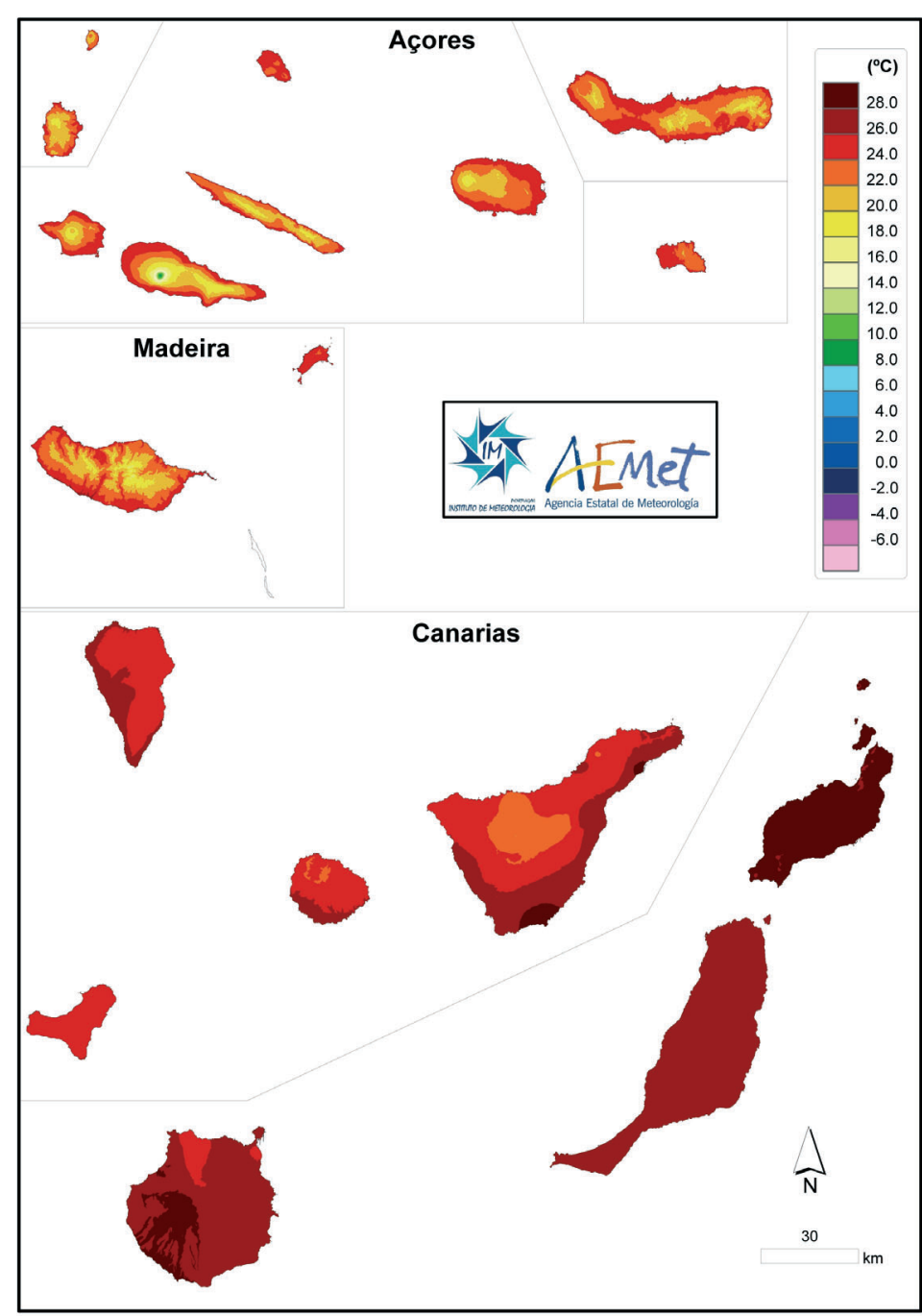

Fig. 47. Temperatura media de las máximas de agosto.

Média da temperatura máxima em Agosto.

Average maximum temperature in August. 


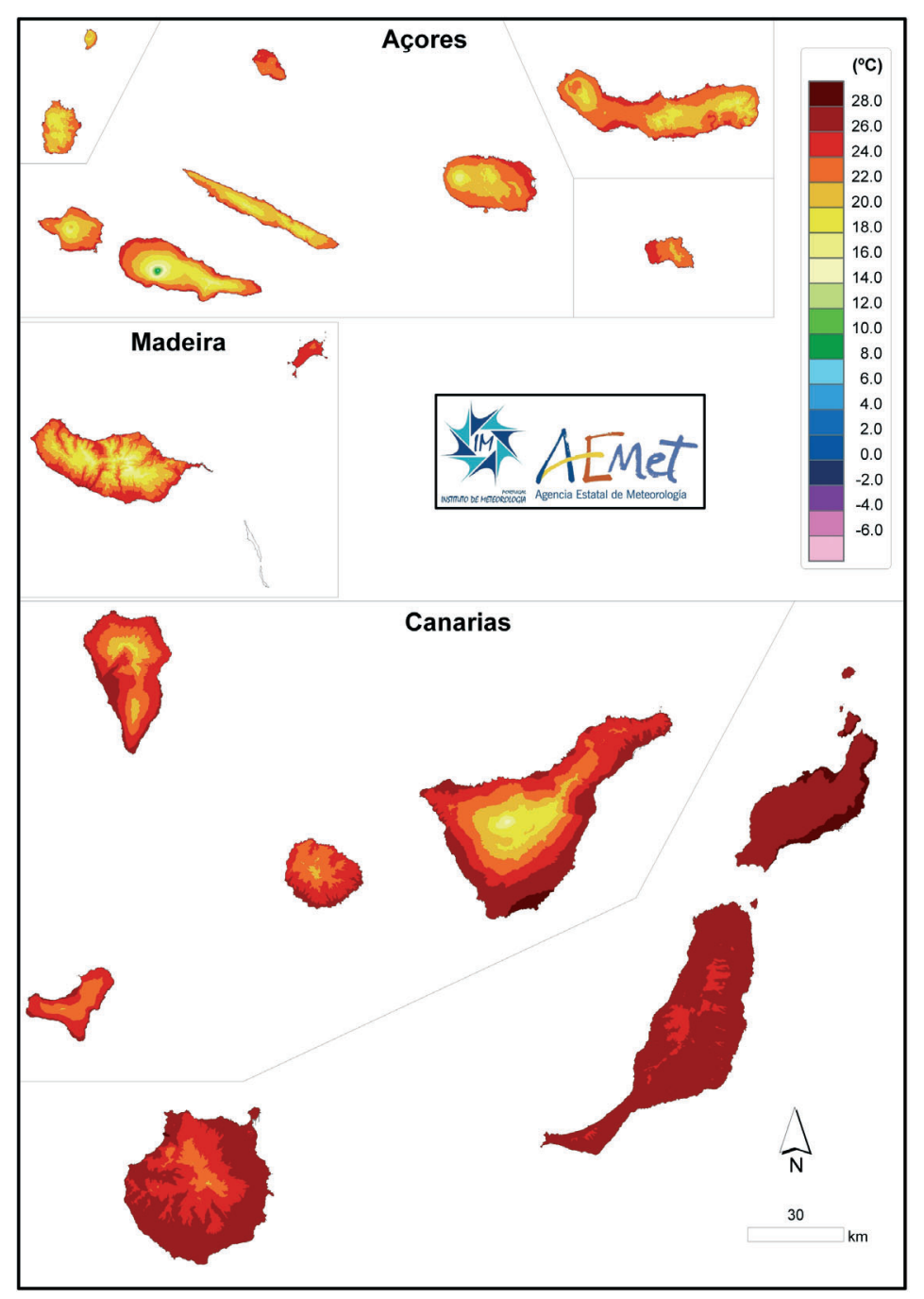

Fig. 48. Temperatura media de las máximas de septiembre.

Média da temperatura máxima em Setembro.

Average maximum temperature in September.

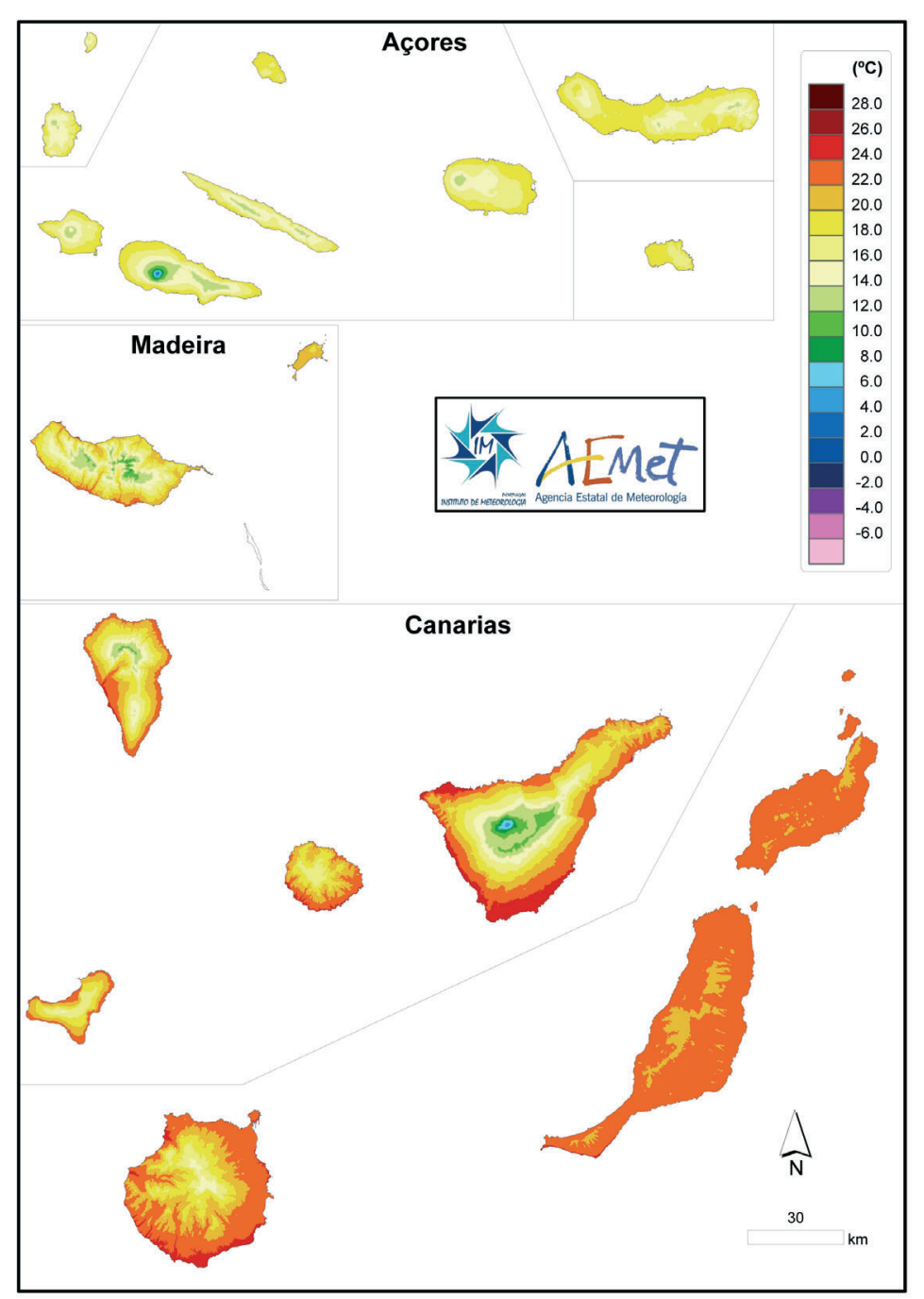

Fig. 50. Temperatura media de las máximas de noviembre.

Média da temperatura máxima em Novembro.

Average maximum temperature in November.

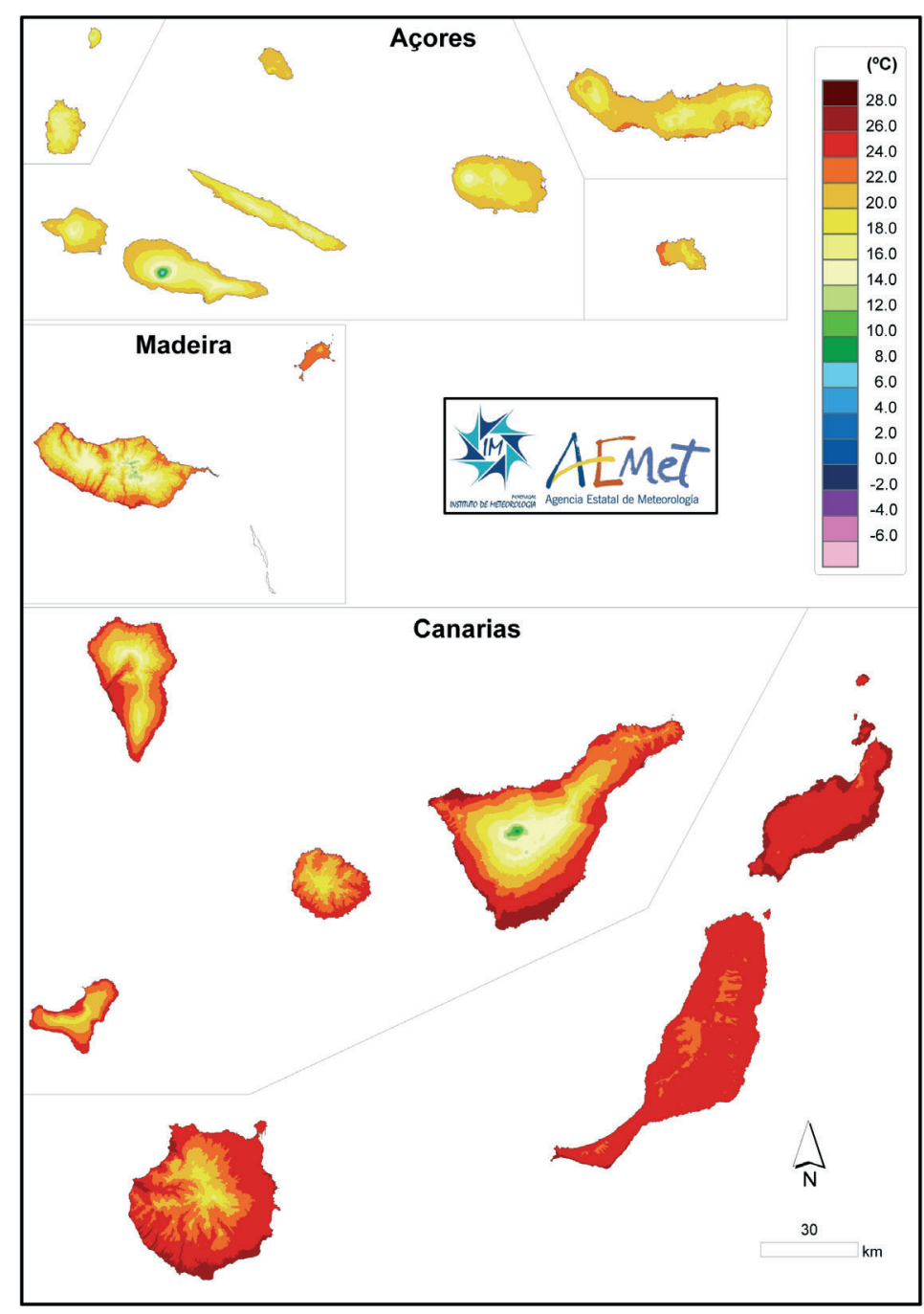

Fig. 49. Temperatura media de las máximas de octubre.

Média da temperatura máxima em Outobro.

Average maximum temperature in October.

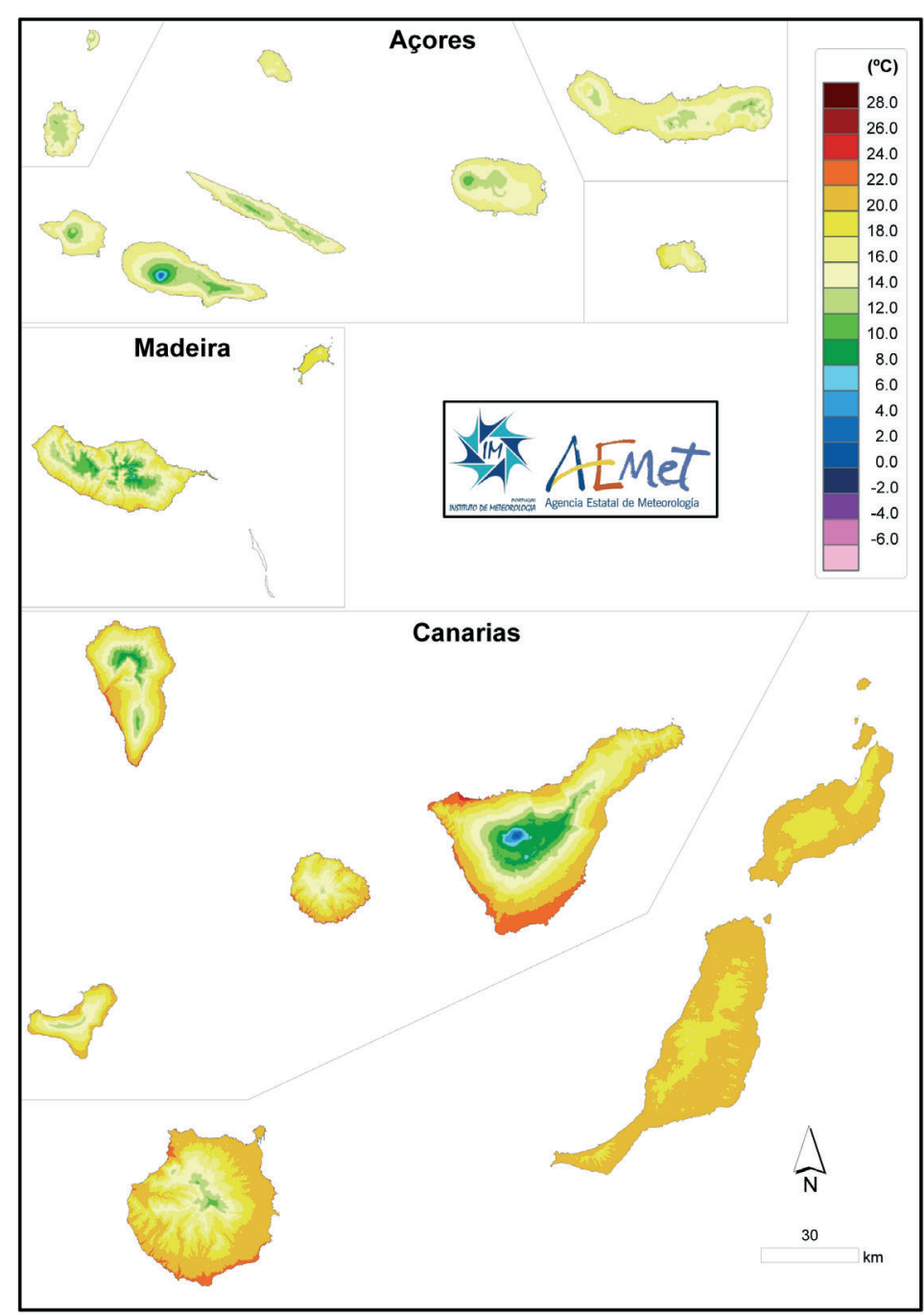

Fig. 51. Temperatura media de las máximas de diciembre.

Média da temperatura máxima em Dezembro.

Average maximum temperature in December. 


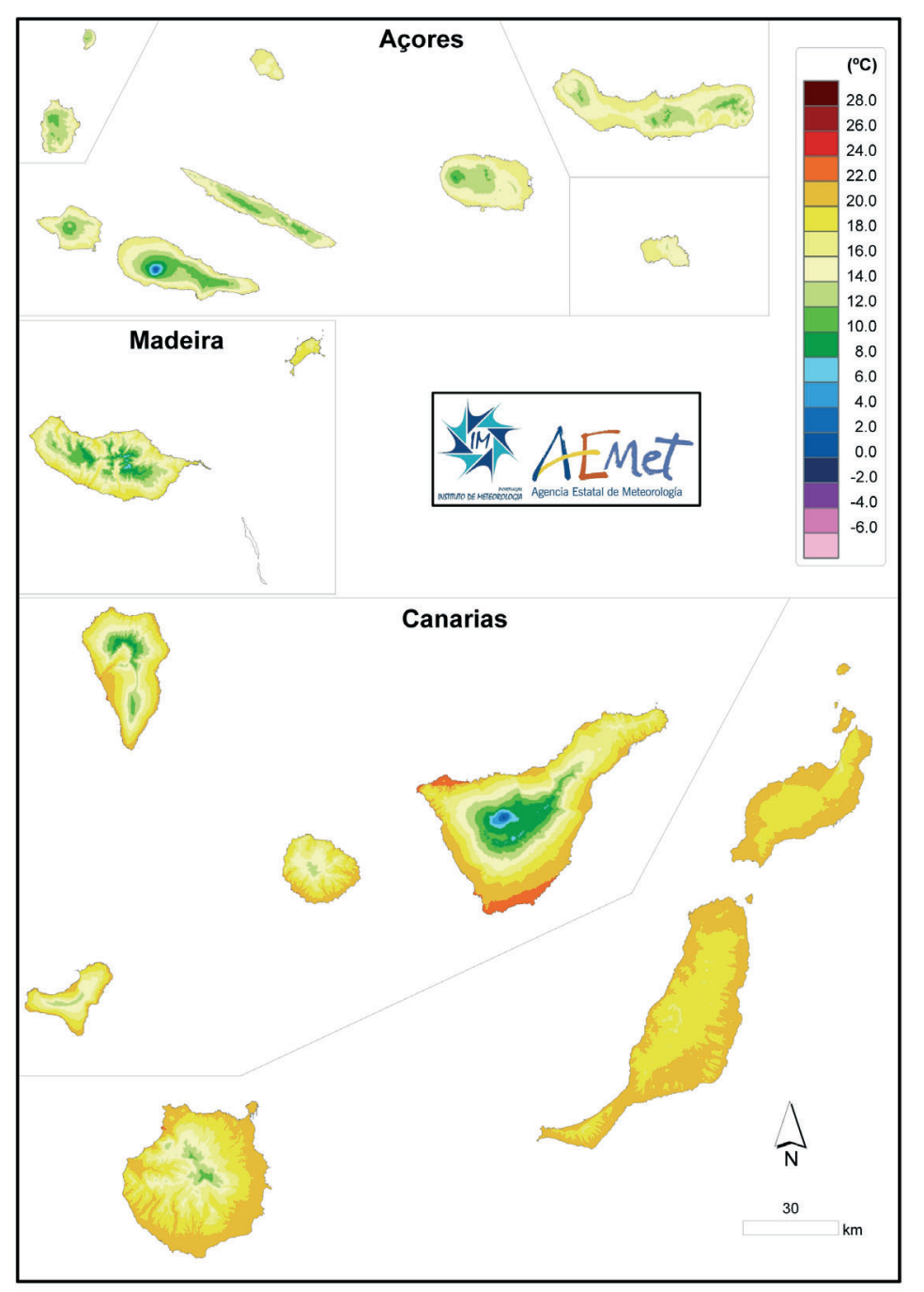

Fig. 52. Temperatura media de las máximas en invierno.

Média da temperatura máxima no Inverno.

Average maximum temperature in winter.

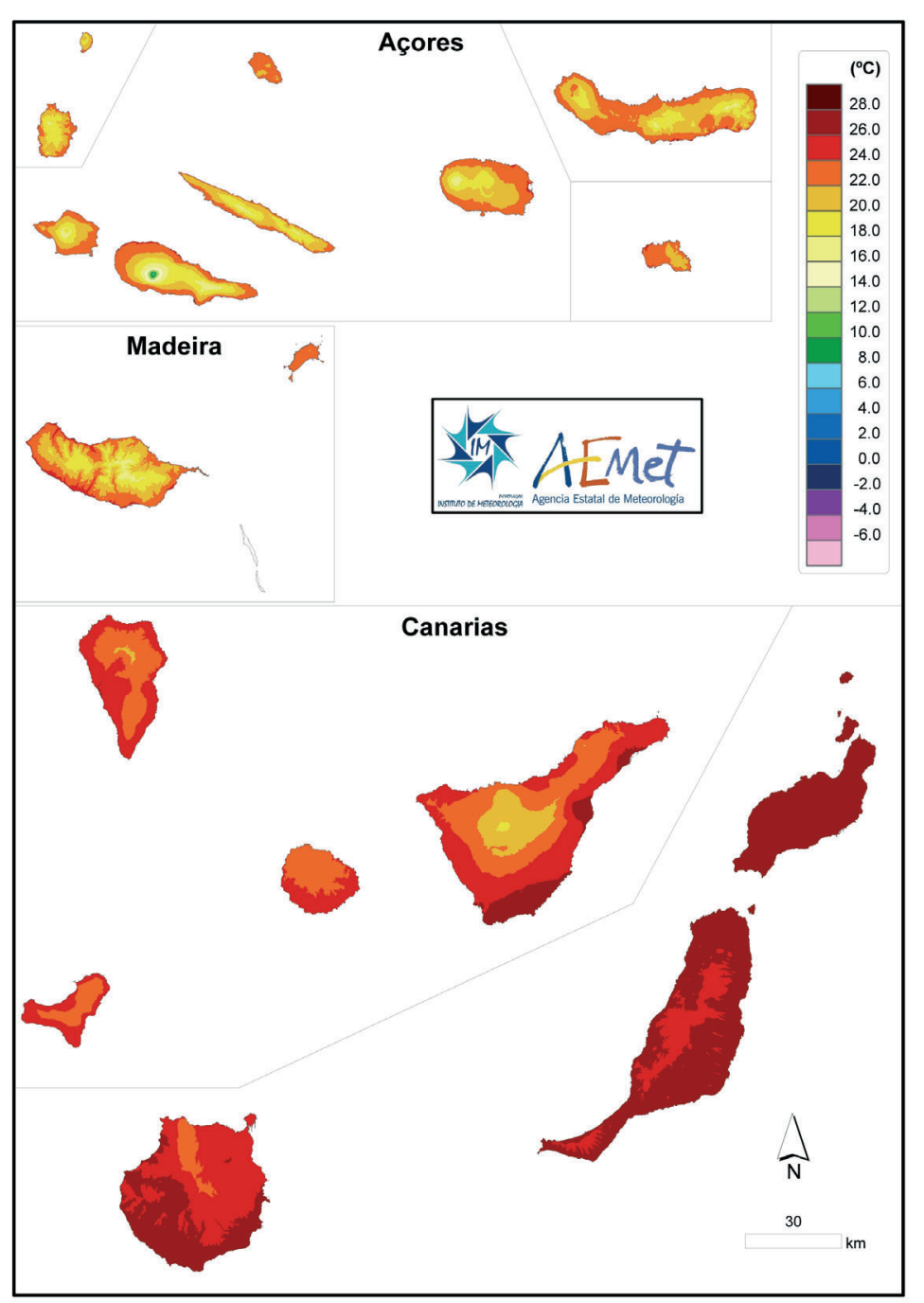

Fig. 54. Temperatura media de las máximas en verano.

Média da temperatura máxima no Verão.

Average maximum temperature in summer.

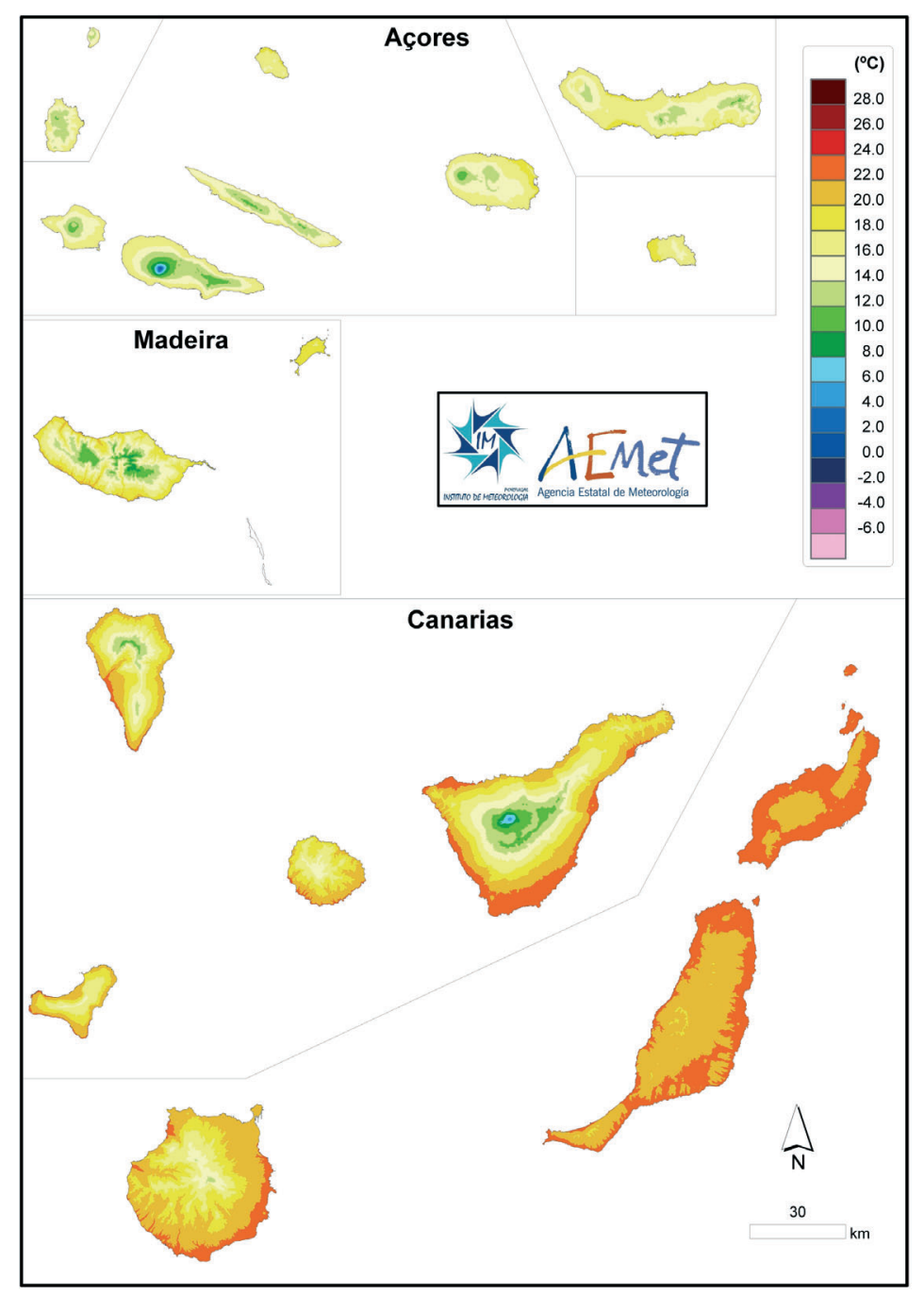

Fig. 53. Temperatura media de las máximas en primavera.

Média da temperatura máxima na Primavera.

Average maximum temperature in spring.

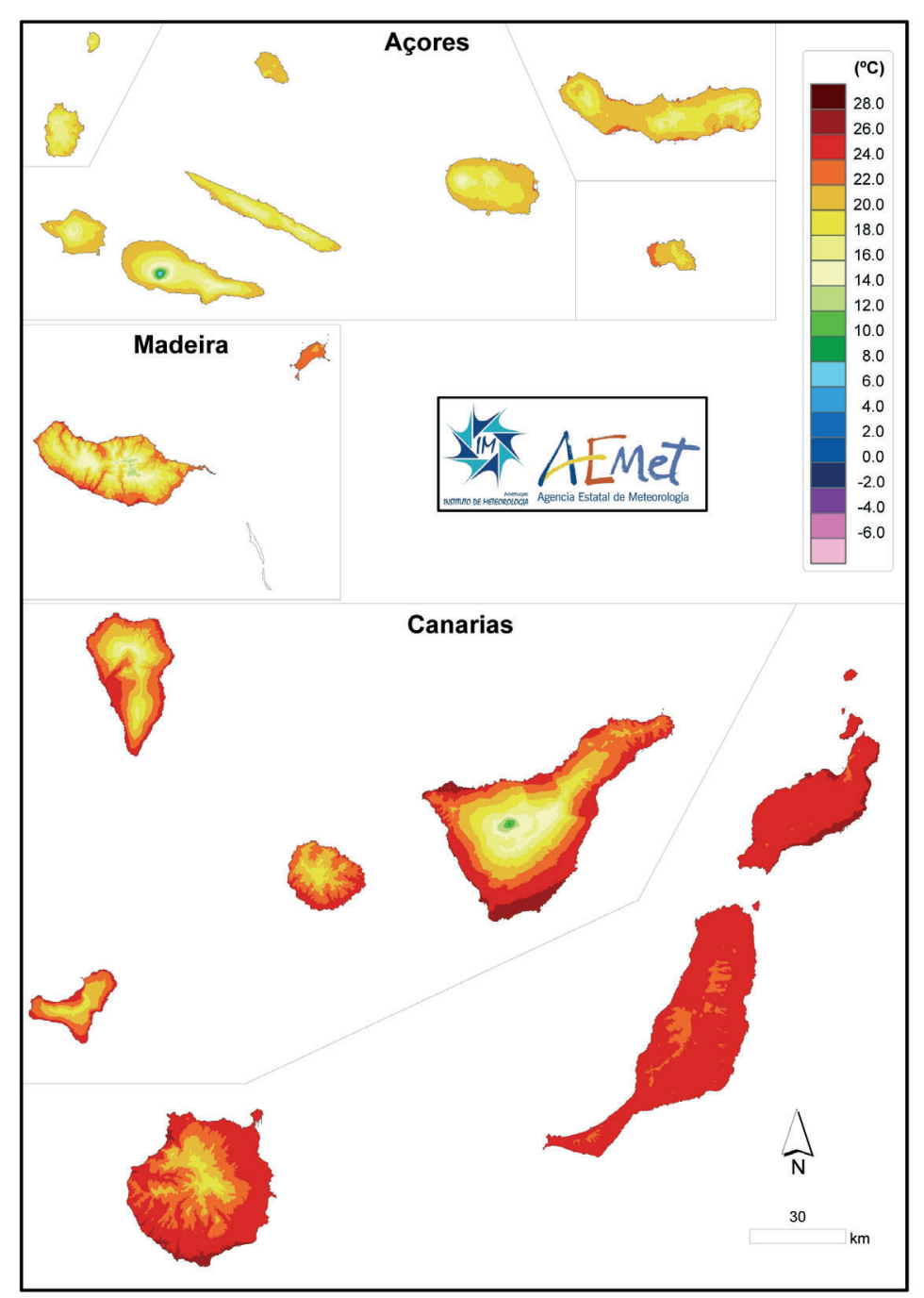

Fig. 55. Temperatura media de las máximas de otoño.

Média da temperatura máxima em Outono.

Average maximum temperature in autumn. 
Número medio de días con temperatura mínima inferior o igual a $0{ }^{\circ} \mathrm{C}$ en los archipiélagos de Canarias, Madeira y Azores (1971-2000) / Número médio de dias com temperatura mínima inferior ou igual a $0^{\circ} \mathrm{C}$ nos arquipélagos das Canárias, da Madeira e dos Açores (1971-2000) / Average number of days with minimum temperature below of equal to $0^{\circ} \mathrm{C}$ in the archipelagos of the Canary Islands, Madeira and the Azores (1971-2000)

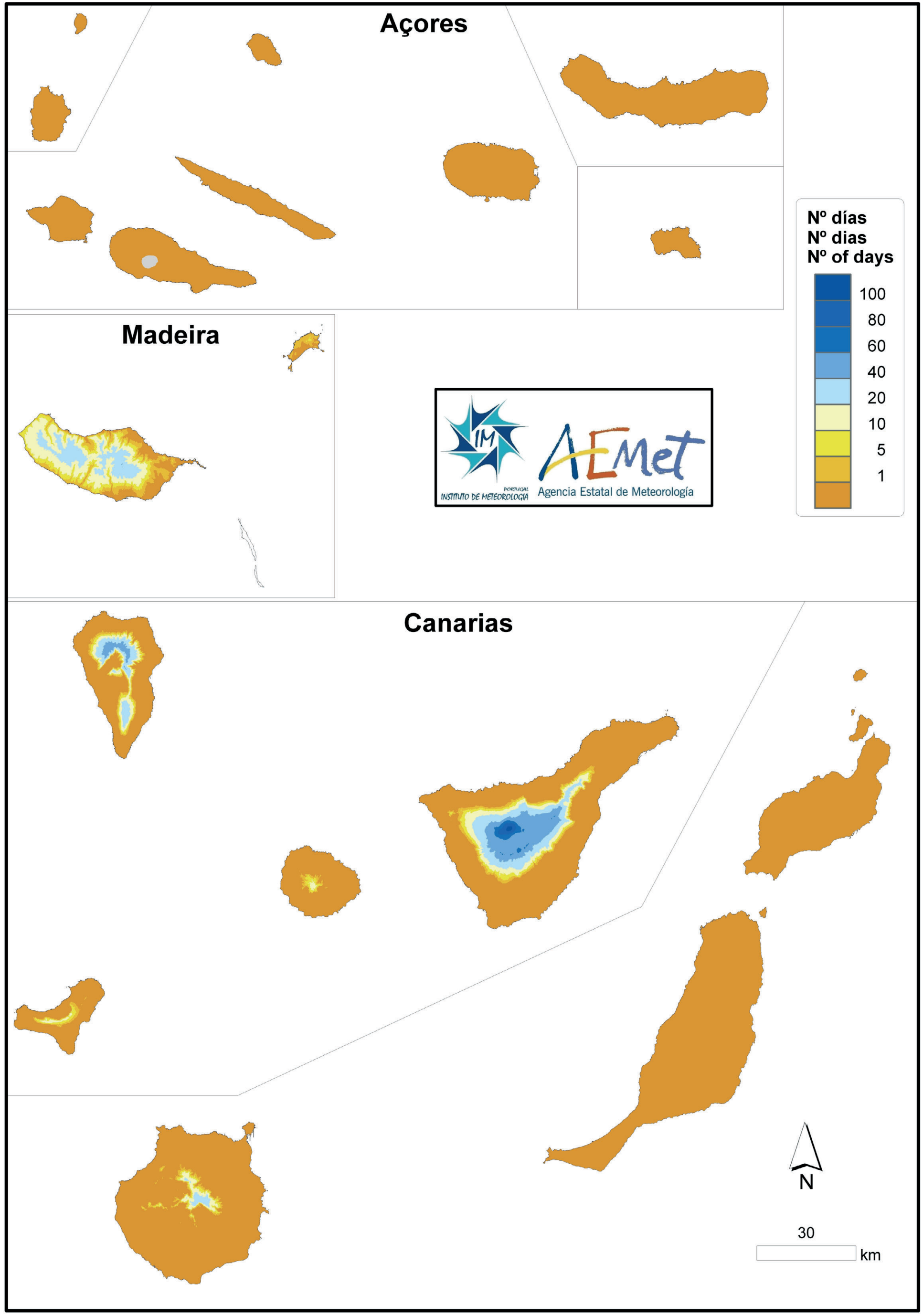

Fig. 56. Número medio anual de días con temperatura mínima $\leq 0^{\circ} \mathrm{C}$.

Número médio de dias com temperatura mínima anual $\leq 0{ }^{\circ} \mathrm{C}$

Annual average number of days with minimum temperature $\leq 0^{\circ} \mathrm{C}$. 
Número medio de días con temperatura mínima superior o igual a $20^{\circ} \mathrm{C}$ en los archipiélagos de Canarias, Madeira y Azores (1971-2000) / Número médio de dias com temperatura mínima superior ou igual a $20^{\circ} \mathrm{C}$ nos arquipélagos das Canárias, da Madeira e dos Açores (1971-2000) / Average number of days with minimum temperature above of equal to $20^{\circ} \mathrm{C}$ in the archipelagos of the Canary Islands, Madeira and the Azores (1971-2000)

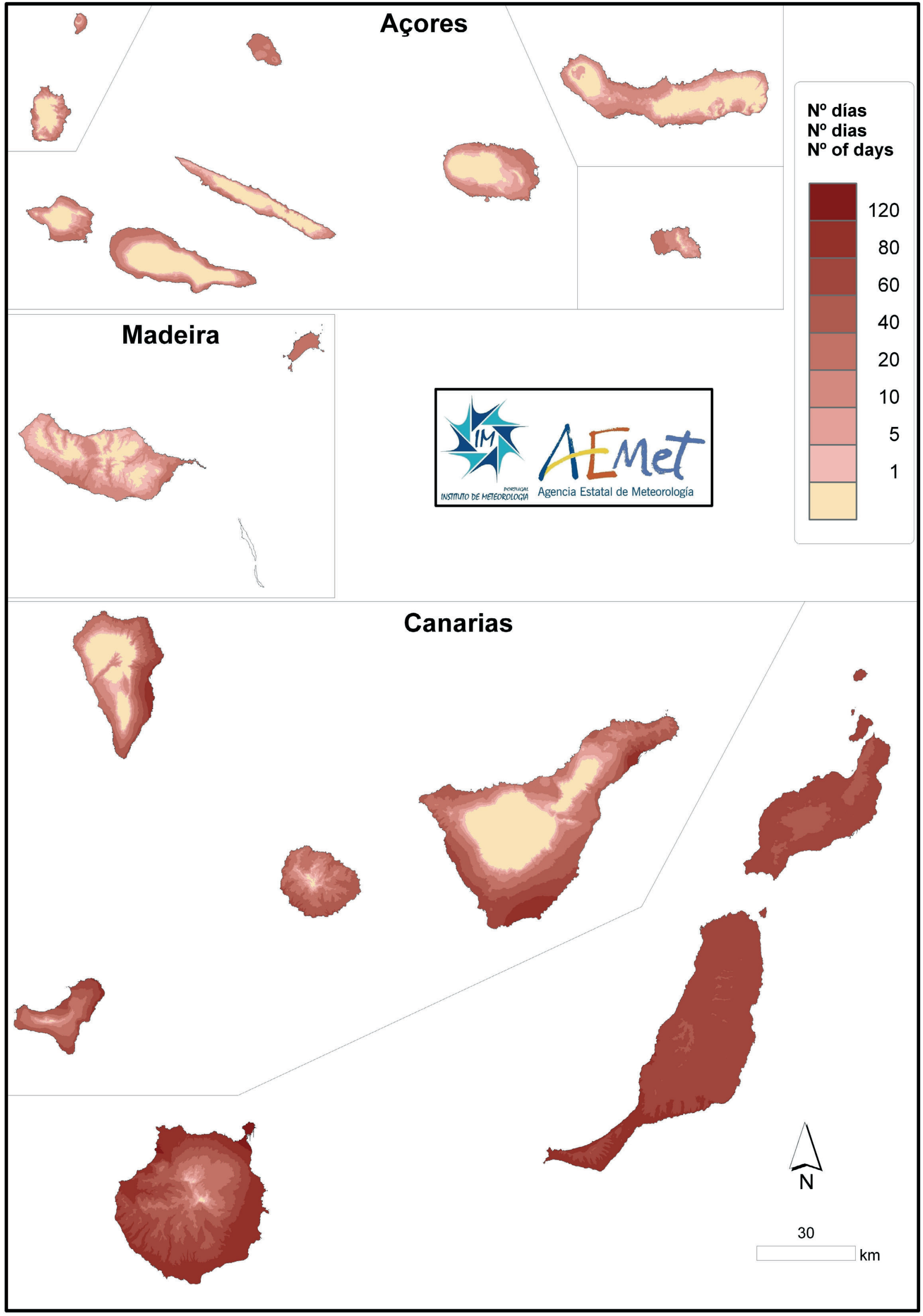

Fig. 57. Número medio anual de días con temperatura mínima $\geq 20^{\circ} \mathrm{C}$.

Número médio de dias com temperatura mínima anual $\geq 20^{\circ} \mathrm{C}$

Annual average number of days with minimum temperature $\geq 20^{\circ} \mathrm{C}$. 
Número medio de días con temperatura máxima superior o igual a $25^{\circ} \mathrm{C}$ en los archipiélagos de Canarias, Madeira y Azores (1971-2000) / Número médio de dias com temperatura máxima superior ou igual a $25^{\circ} \mathrm{C}$ nos arquipélagos das Canárias, da Madeira e dos Açores (1971-2000) / Average number of days with maximum temperature above of equal to $25^{\circ} \mathrm{C}$ in the archipelagos of the Canary Islands, Madeira and the Azores (1971-2000)

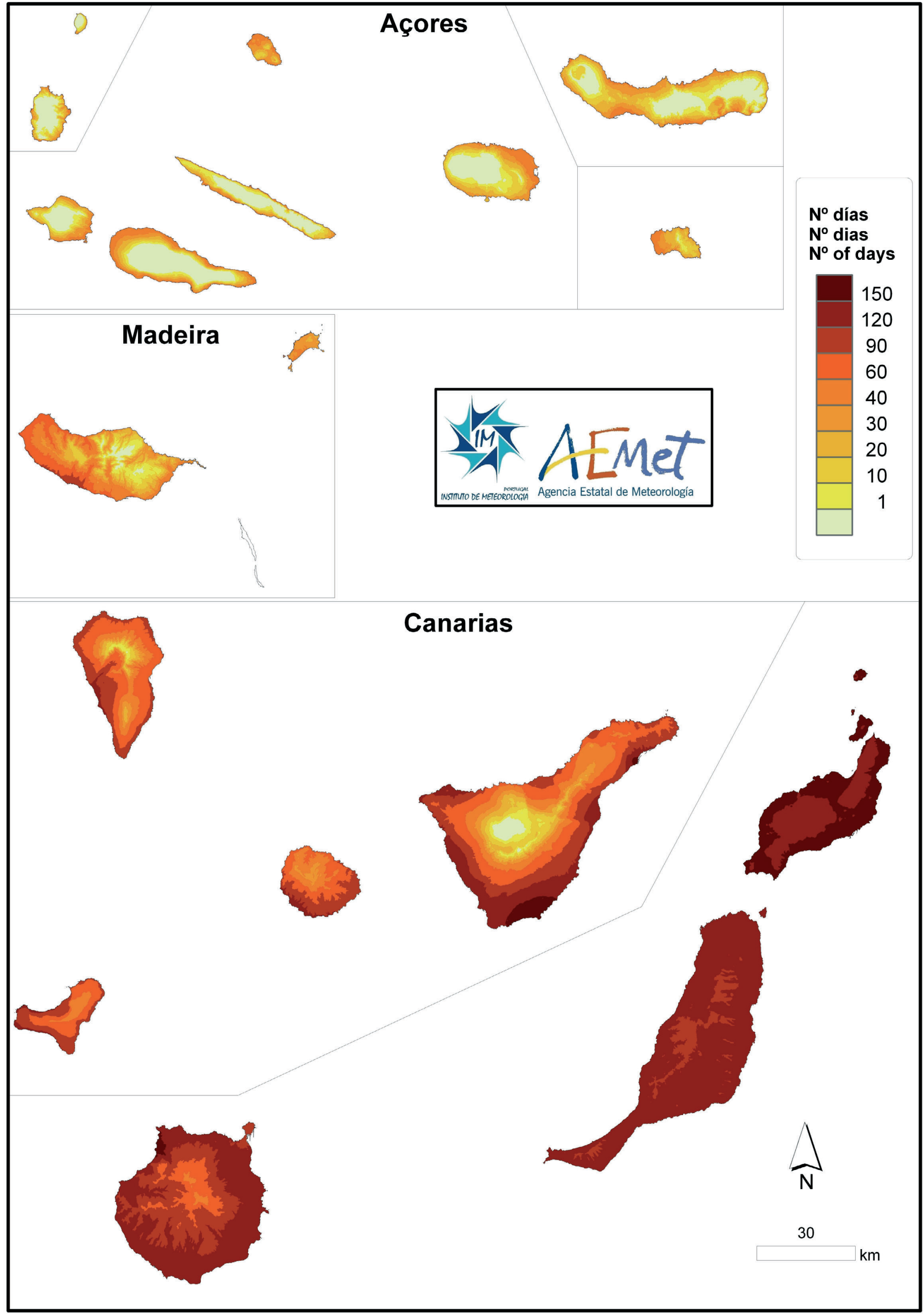

Fig. 58. Número medio anual de días con temperatura máxima $\geq 25^{\circ} \mathrm{C}$.

Número médio de dias com temperatura máxima anual $\geq 25^{\circ} \mathrm{C}$.

Annual average number of days with maximum temperature $\geq 25^{\circ} \mathrm{C}$. 


\section{Precipitación}

La caracterización del régimen de precipitaciones exige tanto el análisis de la precipitación media anual como de la forma en que esta precipitación se distribuye a lo largo del año. Por otro lado se requiere disponer del número anual medio de días en los que se registra precipitación y de la distribución mensual de este número de días, siendo también de gran interés el disponer de la frecuencia climática de ocurrencia de precipitaciones intensas, para lo que se han incluido en este Atlas de los archipiélagos de Canarias, Madeira y Azores los mapas de número medio anual de días en los que la precipitación diaria ha superado una serie de umbrales.

\section{Precipitação}

Para caracterizar o regime de precipitaçoes é importante considerar, tanto a precipitação média anual, como a sua distribuicão temporal ao longo dos meses do ano. Por outro lado, é necessário dispor do número anual médio de dias em que se regista precipitação, assim como a distribuição mensal deste número de dias. É também de grande interesse dispor da frequência climática de ocorrência de precipitações intensas, pelo que se incluíram neste Atlas dos arquipélagos dos Açores, Madeira e Canárias as cartas do número médio anual de dias com precipitação diária superior a determinados valores.

\section{Precipitation}

In order to characterize the precipitation regime it is important to consider both the average annual rainfall as well as its temporal distribution over the months of the year. Moreover, it is necessary to have available the annual number of days in which precipitation is recorded as well as the monthly distribution of this number of days. It is also of great interest to have available the climatic frequency of occurrences of intense precipitation. Therefore included in this atlas of the Azores, Madeira and the Canary Islands are maps showing the average annual number of days with daily precipitation above certain values.

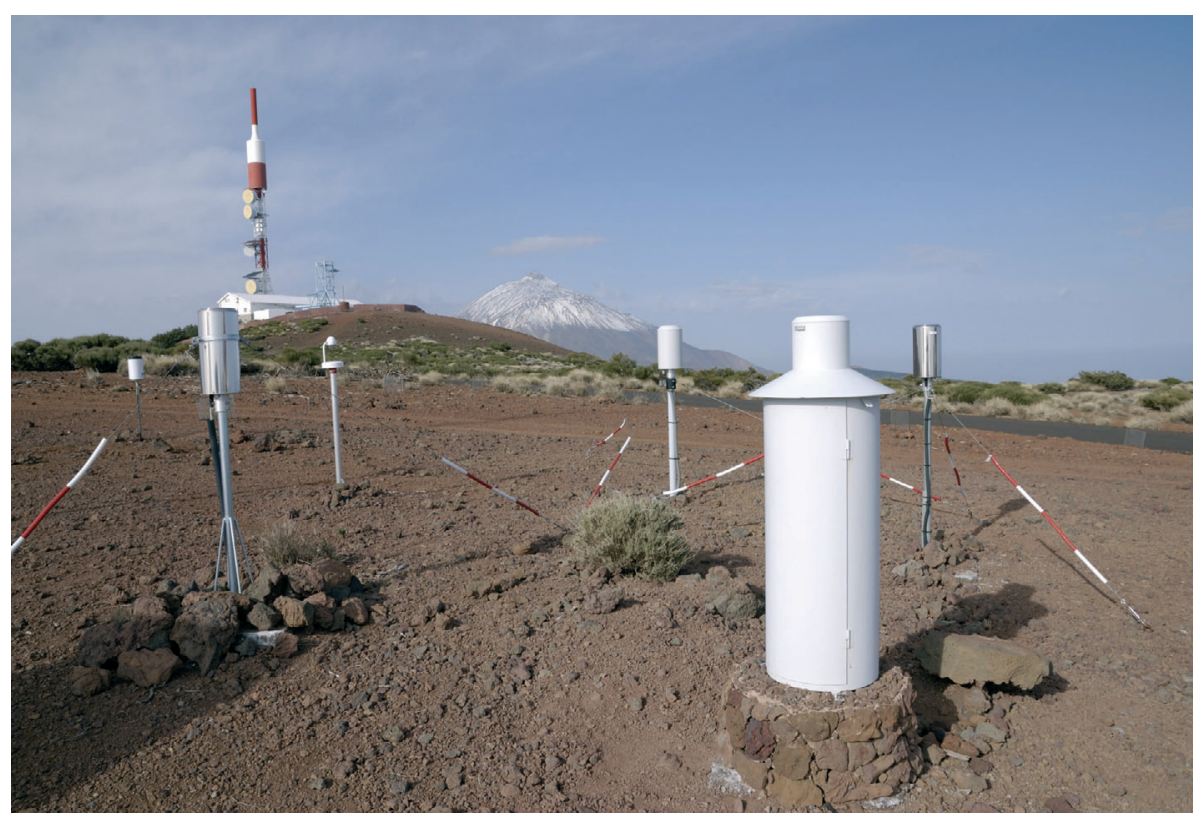

\subsection{Archipiélago de Canarias}

Como se puede observar en los mapas correspondientes, la precipitación media anual en el archipiélago canario presenta una distribución muy desigual en la que los dos factores dominantes son la altitud sobre el nivel del mar y la exposición de la zona a los vientos alisios dominantes. Los valores más elevados se sitúan por encima de los $1000 \mathrm{~mm}$ y se observan en zonas altas de la isla de La Palma, mientras que los valores más bajos, por debajo de los $100 \mathrm{~mm}$, se registran en la costa sur de las islas de Tenerife y Gran Canaria.

Las precipitaciones medias mensuales varían a lo largo del año, con una notable estacionalidad. Los meses más lluviosos en el conjunto del archipiélago canario son los de diciembre y enero. En estos meses en las zonas más altas del centro de la isla de La Palma las precipitaciones medias mensuales superan los $200 \mathrm{~mm}$, mientras que por el contrario en las zonas costeras del sur de Tenerife y Gran Canaria y del este de Fuerteventura quedan por debajo de los $20 \mathrm{~mm}$. Los meses más secos del año son los de julio y agosto.

\subsection{Arquipélago das Canárias}

Como se pode observar nas respetivas cartas, a precipitação média anual do arquipélago das Canárias apresenta uma distribuição muito desigual em que os fatores dominantes são a altitude e a exposição aos ventos alíseos dominantes. Os valores mais elevados, superiores a $1000 \mathrm{~mm}$, observam-se nas cotas mais elevadas da ilha de La Palma, enquanto os valores mais baixos, inferiores a $100 \mathrm{~mm}$, ocorrem na costa Sul das ilhas de Tenerife e Gran Canária.

As precipitações médias mensais variam ao longo do ano, com uma sazonalidade notável. Os meses mais chuvosos no conjunto do arquipélago das Canárias, são dezembro e janeiro. Nestes meses nas cotas mais elevadas do interior da ilha de La Palma as precipitações médias mensais são superiores a $200 \mathrm{~mm}$, enquanto que pelo contrário, nas áreas costeiras do Sul de Tenerife e Gran Canária e a leste de Fuerteventura são inferiores a $20 \mathrm{~mm}$. Os meses mais secos do ano são os de julho e de agosto. Na maior

\subsection{Arquipelago of the Canary Islands}

As can be seen in the respective maps, the average annual rainfall of the Archipelago of the Canary Islands presents a very uneven distribution in which the dominant factors are altitude and exposure to the prevailing trade winds. The highest values, exceeding $1000 \mathrm{~mm}$, are observed in higher altitudes of the island of La Palma, while the lowest values, less than $100 \mathrm{~mm}$, occur on the south coast of the islands of Tenerife and Gran Canaria.

The average monthly precipitation varies throughout the year, with remarkable seasonality. The rainiest months throughout the Canary Islands are December and January. In these months in the highest altitude of the interior of the island of $\mathrm{La}$ Palma the monthly average rainfall exceeds $200 \mathrm{~mm}$. While to the contrary, in the coastal areas of southern Tenerife and Gran Canaria and in the east of Fuerteventura the values are less than $20 \mathrm{~mm}$. The driest months of the year are July and August. In 
En la mayor parte del archipiélago canario no se registran prácticamente precipitaciones en julio y tan solo en algunas zonas del norte de las islas de Tenerife, La Palma y Gran Canaria la precipitación media mensual en dicho mes supera los $5 \mathrm{~mm}$.

Con relación al número anual de días de precipitación mayor de $1 \mathrm{~mm}$, los valores más elevados se registran en zonas altas de las islas de La Palma, La Gomera, El Hierro y Gran Canaria, con más de 50 días al año, mientras que los más bajos, con menos de 10 días al año, corresponden a la costa sur de Gran Canaria. La distribución geográfica de la frecuencia de precipitaciones intensas es similar a la anterior, de forma que el número medio anual de días con precipitación mayor de $10 \mathrm{~mm}$ alcanza valores por encima de 20 en el centro y norte de La Palma, nordeste de Tenerife y otras zonas altas ubicadas en el centro de Gran Canaria, La Gomera y El Hierro mientras que los valores más bajos, sin llegar en promedio a 3 días por año, se registran en las costas del sur de Gran Canaria y Tenerife y en el este de Lanzarote. Si se eleva el umbral hasta $30 \mathrm{~mm}$ el número de días de precipitación superior a este valor supera los 10 días en las zonas más altas de La Palma, mientras que no llega a un día en la isla de Lanzarote y en la mayor parte de Fuerteventura y de las zonas costeras de Gran Canaria.

\subsection{Archipiélagos de Madeira y Azores}

La distribución de la precipitación media anual registrada en el archipiélago de las Azores en las cotas más bajas varía de oeste a este, siendo más abundante en las islas del Grupo Occidental, en la isla de Flores donde se registran de media $1665,6 \mathrm{~mm}$ (Boca da Baleia), y registrándose las menores cantidades de precipitación en el Grupo Oriental, en la isla de Santa María (729,5 mm). Pero la cantidad de precipitación media anual en este archipiélago también está influenciada en gran medida por la orografía, registrándose los valores medios anuales más elevados en algunas islas con cotas más altas, como es el caso de la precipitación registrada en algunos lugares de la isla de Pico, donde pueden alcanzarse valores superiores a $4000 \mathrm{~mm} / \mathrm{año}$, como por ejemplo en la Lagoa do Caiado, con una de media 4 694,8 mm.

La precipitación en las Azores es más abundante en los meses de noviembre, diciembre y enero, registrándose de media, durante estos meses, cantidades superiores a $500 \mathrm{~m}$. Los valores más elevados se observan en cotas más altas (ej., Lagoa do Caiado con 714,0 mm en diciembre). Durante los meses de junio a agosto se alcanzan los valores medios más bajos de precipitación en las Azores, registrándose en la isla Terceira —en Farol da Serrata- 21,6 mm en julio. Pero el período seco estival en este archipiélago es muy corto; a pesar de observarse el contraste entre las islas del Grupo Occidental y Oriental y de registrarse los valores medios más altos de precipitación durante este período estival en lugares de mayor altitud, en las islas occidentales no existe estación seca.

El número de días con precipitación superior o igual a 0,1 mm en las Azores es elevado, en todas las islas se registran más de 120 días/año, siendo el número más alto en la isla de Flores/Aeropuerto (240 días/año). El número de días con precipitación superior o igual a 1 y a $10 \mathrm{~mm}$ también es elevado, registrándose más días en la isla de San Miguel/Cerrado con 178 días/año y en la isla de Faial/Cabouco/ Sátão con 71 días/año. Para el caso de precipitaciones diarias intensas, considerando el número medio anual de días con precipitación superior o igual a parte do arquipélago das Canárias não se regista praticamente precipitação em julho e apenas em algumas áreas do norte das ilhas de Tenerife, La Palma e Gran Canária supera os $5 \mathrm{~mm}$ de precipitação mensal nesse mês.

Em relação ao número médio anual de dias com precipitação superior ou igual a $1 \mathrm{~mm}$, os valores mais elevados ocorrem em áreas de maior altitude das ilhas de La Palma, La Gomera, de El Hierro, e Gran Canária, com mais de 50 dias, enquanto os mais baixos, com menos de 10 dias anuais, correspondem à costa Sul da ilha de Gran Canária. A distribuição geográfica da frequência de precipitações intensas é semelhante à anterior, de forma que o número médio anual de dias com precipitação superior ou igual a $10 \mathrm{~mm}$ atinge valores superiores a 20 dias no interior de $\mathrm{La} \mathrm{Pal}-$ ma, nordeste de Tenerife e outras áreas localizadas no centro da ilha de Gran Canária, La Gomera e de El Hierro, enquanto os valores mais baixos, que não atingem os 3 dias anuais, ocorrem nas costas Sul da ilha de Gran Canária, Tenerife e a este de Lanzarote. Se elevarmos o limiar para os $30 \mathrm{~mm}$, o número de dias com precipitação superior ou igual a este valor não atinge os 10 dias anuais nas áreas mais elevadas de La Palma, enquanto que na ilha de Lanzarote, na maior parte de Fuerteventura e nas áreas costeiras da ilha de Gran Canária não se regista nenhum dia.

\subsection{Arquipélagos da Madeira e dos Açores}

A distribuição da precipitação média anual registada no arquipélago dos Açores nas cotas mais baixas, varia de oeste para este, sendo mais abundante nas ilhas do Grupo Ocidental, na ilha das Flores onde se regista em média $1665,6 \mathrm{~mm}$ (Boca da Baleia), e registando-se as menores quantidades de precipitação no Grupo Oriental, na ilha de Santa Maria $(729,5 \mathrm{~mm})$. Mas, a quantidade de precipitação média anual, neste arquipélago, também é fortemente influenciada pela orografia, registando-se os valores médios anuais mais elevados em algumas ilhas com cotas mais altas, como é o caso da precipitação registada em alguns locais na ilha do Pico, onde podem ocorrer valores superiores a $4000 \mathrm{~mm} / \mathrm{ano}$, como por exemplo na Lagoa do Caiado, nesta ilha, que regista em média 4 694,8 mm.

A precipitação nos Açores é mais abundante nos meses de novembro, dezembro e janeiro, registandose em média, durante estes meses, quantidades superiores a $500 \mathrm{~mm}$; os valores mais elevados são registados em cotas mais altas (e.g. Lagoa do Caiado $714,0 \mathrm{~mm}$ em dezembro). Durante os meses de junho a agosto são registadas os valores médios mais baixos de precipitação nos Açores, registando-se na ilha Terceira em Farol da Serrata 21,6 mm em julho; mas, o período seco estival neste arquipélago é muito curto, apesar de se observar o contraste entre as ilhas do Grupo Ocidental e Oriental e se registarem os valores médios mais altos de precipitação durante este período estival em locais de maior altitude, nas ilhas ocidentais não existe estação seca.

O número de dias com precipitação superior ou igual a $0,1 \mathrm{~mm}$ nos Açores é elevado, em todas as ilhas são registados mais de 120 dias/ano, sendo o número mais alto na ilha das Flores/Aeroporto (240 dias/ano). O número de dias com precipitação superior ou igual a 1 e a $10 \mathrm{~mm}$ também é elevado, registando-se mais dias, na ilha de São Miguel/Cerrado com 178 dias/ano e na ilha do Faial/Cabouco/Sátão com 71 dias/ano. Para o caso de precipitações diárias intensas, considerando o número médio anual de dias com precipitação maior ou igual a $30 \mathrm{~mm}$, os maiores most of the Canary Islands almost not precipitation is recorded in July and only in some areas in the north of the islands of Tenerife, La Palma and Gran Canaria, reaching values greater than $5 \mathrm{~mm}$ of precipitation in this month.

Regarding the average annual number of days with precipitation greater than or equal to $1 \mathrm{~mm}$, the highest values occur in areas of higher altitude of the islands of La Palma, La Gomera, El Hierro and Gran Canaria, with more than 50 days, while the lowest, with less than 10 days per year, corresponds to the southern coast of the island of Gran Canaria. The geographical distribution of the frequency of intense precipitation is similar to the previous, so that the average annual number of days with precipitation greater than or equal to $10 \mathrm{~mm}$ reaches values exceeding 20 days in the interior of La Palma, northern Tenerife and other areas located in the centre of the island of Gran Canaria, La Gomera and El Hierro. Moreover the lowest values, which do not reach 3 days per year, occur in the south coasts of the island of Gran Canaria, Tenerife and to the east of Lanzarote. If we raise the threshold to $30 \mathrm{~mm}$, the number of days with precipitation greater than or equal to this value does not reach 10 days per year in the highest areas of La Palma, while on the island of Lanzarote, and in most parts of Fuerteventura and coastal areas of the island of Gran Canaria, not one day is recorded.

\subsection{Archipelagos of Madeira and the Azores}

The distribution of average annual precipitation recorded in the archipelago of the Azores, in the lower elevations, varies from west to east, being most abundant on the islands of the Western Group, on Flores Island where there is an average of $1665.6 \mathrm{~mm}$ (Boca da Baleia), with the island of Santa Maria registering the lowest amount of precipitation in the Eastern Group, $(729.5 \mathrm{~mm})$. But the amount of average annual precipitation in this archipelago is also strongly influenced by topography, with the highest annual average being registered on the islands with some of the highest altitudes, as is the case of precipitation recorded in some locations on the island of Pico, where there may be values greater than $4000 \mathrm{~mm} /$ year, for example as with in Lagoa do Caiado where an average of $4694.8 \mathrm{~mm}$ is recorded.

The precipitation is more abundant in the Azores in November, December and January, registering on average during these months, amounts greater than $500 \mathrm{~mm}$. The highest values are recorded at higher altitudes (e.g. Lagoa do Caiado $714.0 \mathrm{~mm}$ in December). During the months of June to August the average lowest precipitation values are recorded in the Azores, registering $21.6 \mathrm{~mm}$ in July at Farol da Serrata on Terceira Island. But the dry summer season on this archipelago is very short, although the contrast between the islands of the Western and Eastern Group was observed and the highest average precipitation values were recorded during this summer in locations of higher altitude, in the western islands there is no dry season.

The number of days with precipitation greater than or equal to $0.1 \mathrm{~mm}$ in the Azores is high, throughout all the islands, over 120 days/year are recorded, with the highest number on Flores Island/ Airport (240 days/year). The number of days with precipitation greater than or equal to 1.0 and $10.0 \mathrm{~mm}$ is also high, registering more days on the island of São Miguel/Cerrado with 178 days/year and in Faial/Cabouco/Sátão with 71 days/year. In the case of intense daily precipitation, taking into account the average annual number of days with pre- 
$30 \mathrm{~mm}$, el mayor número de días se observa en las islas del Grupo Central (Faial y San Jorge).

En el archipiélago de Madeira la precipitación media anual presenta una variación entre islas, siendo la cantidad de precipitación más abundante en la isla de Madeira que en la isla de Porto Santo (Aeropuerto, 361,3 mm), registrándose en Funchal de media 596,4 mm. En la isla de Madeira se observa que la cantidad media de precipitación anual está muy influenciada por la orografía, siendo más abundante en las cotas más altas de la isla (Encumeada, 2 794,0; Bica da Cana, 2 635,0; y Arieiro, 2620,0 mm/año) y también se puede apreciar una diferencia entre las vertientes septentrionales y las vertientes meridionales de la isla, siendo más elevadas las cantidades de precipitación en las primeras.

La precipitación en el archipiélago es más abundante en los meses de diciembre y de enero y en la isla de Madeira se registra una gran variación de la precipitación entre las cotas más bajas y las más altas, alcanzándose las cantidades más bajas en el litoral de la costa sur de la isla. En Funchal, en diciembre, se registran 109,4 mm y en los lugares de cotas más altas se registran 477,4 mm (Encumeada). El período seco en algunos puntos de la isla de Madeira es muy corto, limitándose al mes de julio, pero durante el período estival (junio a agosto) los valores de las cantidades medias de precipitación son bajos. A pesar de observarse una variación de la cantidad media de precipitación entre las cotas más bajas y las más altas, se registran respectivamente 2,3 mm en Lugar de Baixo en julio y 66,0 mm en Bica da Cana en junio.

El número de días con precipitación superior o igual a $0,1 \mathrm{~mm}$ presenta una gran variación entre las islas del archipiélago, observándose el mayor número de días en los puntos más altos de la isla de Madeira (Arieiro, 188 días/año) y el menor en las cotas más bajas (Lugar de Baixo, 65 días/año). En el número de días con precipitación superior o igual a 1 y a $10 \mathrm{~mm}$, los valores más elevados se observan también en los puntos más altos de la isla de Madeira, respectivamente, en Arieiro, 157 días/año, y en Bica da Cana, 70,1 días/año. El número de días con precipitación superior o igual a $10 \mathrm{~mm}$ es bajo en Funchal (19 días/año) y en Porto Santo (9 días/año). El número medio anual de días con precipitación superior o igual a $30 \mathrm{~mm}$ en las cotas más bajas de la isla de Madeira y en Porto Santo es muy bajo, respectivamente, Machico 2 días/año y Porto Santo 1 día/año y los valores más elevados se registran en cotas más altas de la isla de Madeira (Encumeada, 28 días/año). números de dias registam-se nas ilhas do Grupo Central (Faial e São Jorge).

No arquipélago da Madeira a precipitação média anual apresenta uma variação inter-ilhas, sendo a quantidade de precipitação mais abundante na ilha da Madeira que na ilha de Porto Santo (Aeroporto $361,3 \mathrm{~mm})$, registando-se no Funchal em média $596,4 \mathrm{~mm}$. Na ilha da Madeira observa-se que a quantidade média da precipitação anual é fortemente influenciada pela orografia, sendo mais abundante nas cotas mais altas da ilha (Encumeada, 2 794,0; Bica da Cana, 2 635,0; e Arieiro, 2620,0 mm/ano) e ainda uma distinção da precipitação entre as vertentes setentrionais relativamente à registada nas vertentes meridionais da ilha, sendo que nas primeiras as quantidades de precipitação são mais elevadas.

A precipitação no arquipélago é mais abundante nos meses de dezembro e de janeiro e na ilha da Madeira verifica-se uma grande variação da precipitacão entre as cotas mais baixas e as mais altas, registando-se as quantidades mais baixas junto ao litoral da costa sul da ilha; no Funchal em dezembro registam-se 109,4 mm e nos locais de cotas mais altas registam-se 477,4 mm (Encumeada). O período seco em alguns pontos da ilha da Madeira é muito curto, resumindo-se apenas ao mês de julho, mas durante o período estival (junho a agosto) os valores das quantidades médias de precipitação são baixos. Apesar de se observar uma variação da quantidade média de precipitação entre as cotas mais baixas e as mais altas, regista-se, respetivamente, 2,3 $\mathrm{mm}$ em Lugar de Baixo em julho e $66,0 \mathrm{~mm}$ em Bica da Cana em junho.

$\mathrm{O}$ número de dias com precipitação superior ou igual $0,1 \mathrm{~mm}$ apresenta uma grande variação entre as ilhas do arquipélago, observando-se o maior número de dias nos pontos mais altos da ilha da Madeira (Arieiro, 188 dias/ano) e o menor nas as cotas mais baixas (Lugar de Baixo, 65 dias/ano). No número de dias com precipitação superior ou igual a 1 e a $10 \mathrm{~mm}$, os valores mais elevados observam-se também nos pontos mais altos da ilha da Madeira, respetivamente, no Arieiro 157 dias/ano e em Bica da Cana 70,1 dias/ ano. O número de dias com precipitação superior ou igual $10 \mathrm{~mm}$ é baixo no Funchal (19 dias/ano) e em Porto Santo (9 dias/ano). O número médio anual de dias com precipitação superior ou igual a $30 \mathrm{~mm}$ nas cotas mais baixas da ilha da Madeira e no Porto Santo são muito baixos, respetivamente, Machico 2 dias/ ano e Porto Santo 1 dia/ano, e os valores mais elevados registam-se em cotas mais altas da ilha da Madeira (Encumeada, 28 dias/ano). cipitation greater than or equal to $30 \mathrm{~mm}$, the highest number of days is recorded on the islands of the Central Group (Faial and São Jorge).

On the Madeira Islands the average annual precipitation shows a variation between the islands, with the precipitation being more abundant on the island of Madeira than on the island of Porto Santo (Airport $361.3 \mathrm{~mm}$ ), registering an average of $596.4 \mathrm{~mm}$ in Funchal. On the island of Madeira it is observed that the average annual precipitation is strongly influenced by topography. There is a higher amount of precipitation in higher altitudes on the island (Encumeada 2 794.0, and Bica da Cana 2635.0 and Arieiro $2620.0 \mathrm{~mm}$ /year) and a there is a difference in precipitation between the values on the northern parts compared to that recorded on the southern parts of the island, and in the former the quantities of precipitation are greater.

The precipitation is more abundant in the archipelago during the months of December and January and in Madeira there is a wide variation in precipitation between the lower and higher elevations, registering the lowest amounts along the south coast of the island. In Funchal in December the value registered is $109.4 \mathrm{~mm}$ and in locations of higher altitudes values of $477.4 \mathrm{~mm}$ are recorded (Encumeada). The dry period in some parts of the island of Madeira is very short, covering only the month of July, but during the summer period (June to August) the values of the average amounts of precipitation are low. While observing a variation of the average amount of precipitation between the lower and higher elevations, values of $2.3 \mathrm{~mm}$ in Lugar de Baixo in July, and $66.0 \mathrm{~mm}$ in Bica da Cana in June are recorded respectively.

The number of days with precipitation greater than or equal to $0.1 \mathrm{~mm}$ shows a wide variation between the islands of the archipelago, with the highest number of days in the upper parts of the island of Madeira (Arieiro, 188 days/year) being observed and the lowest value at the lowest altitudes (Lugar de Baixo, 65 days/year). In the number of days with precipitation greater than or equal to 1 and $10 \mathrm{~mm}$, the highest values were also observed in the upper parts of the island of Madeira, respectively, in Arieiro 157 days/year and in Bica da Cana 70.1 days/year. The number of days with precipitation greater than or equal to $10 \mathrm{~mm}$ is low in Funchal (19 days/year) and Porto Santo (9 days/year). The average annual number of days with precipitation greater than or equal to $30 \mathrm{~mm}$ in the lower elevations of Madeira and Porto Santo are very low, respectively, Machico 2 days/year and Porto Santo 1 day/year and the highest values are recorded in higher altitudes of Madeira (Encumeada, 28 days/year). 
Valores medios anuales y extremos más altos de la precipitación en el período 1971-2000

Maiores valores médios anuais e extremos da precipitação no período 1971-2000

Highest annual average and extreme values for precipitation for the period 1971-2000

\begin{tabular}{|c|c|c|c|c|}
\hline \multicolumn{5}{|c|}{$\begin{array}{l}\text { VALORES MEDIOS ANUALES MÁS ALTOS DE LA CANTIDAD DE PRECIPITACIÓN } \\
\text { MAIORES VALORES MÉDIOS ANUAIS DA QUANTIDADE DE PRECIPITAÇÃO } \\
\text { HIGHEST ANNUAL AVERAGE VALUES FOR PRECIPITATION }\end{array}$} \\
\hline \multirow{2}{*}{$\begin{array}{l}\text { Archipiélago } \\
\text { Arquipélago } \\
\text { Archipelago }\end{array}$} & \multirow{2}{*}{$\begin{array}{l}\text { Lugar } \\
\text { Local } \\
\text { Location }\end{array}$} & \multirow{2}{*}{\begin{tabular}{|c|}
$\begin{array}{c}\text { Media anual } \\
\text { Média anual } \\
\text { Annual average }\end{array}$ \\
(mm) \\
\end{tabular}} & \multicolumn{2}{|c|}{$\begin{array}{l}\text { Valor más alto } \\
\text { Maior valor } \\
\text { Highest value }\end{array}$} \\
\hline & & & $(\mathbf{m m})$ & Año/Ano/Year \\
\hline \multirow{5}{*}{ CANARIAS } & Vallehermoso-Igualero/La Gomera ${ }^{1}$ & 634,0 & 1083,1 & 1987 \\
\hline & Tacoronte-Caridad/Tenerife ${ }^{2}$ & 632,2 & 989,8 & 1989 \\
\hline & $\begin{array}{l}\text { Moya-Lomo La Majadilla/ } \\
\text { Gran Canaria }^{3}\end{array}$ & 593,0 & 973,9 & 1979 \\
\hline & Garafía-Tricias/La Palma ${ }^{3}$ & 585,4 & 886,8 & 1987 \\
\hline & $\begin{array}{l}\text { San Mateo-Cueva Grande/ } \\
\text { Gran Canaria }^{4}\end{array}$ & 574,2 & 951,2 & 1984 \\
\hline \multirow{5}{*}{ MADEIRA } & Encumeada/Madeira & 2794,0 & 4383,2 & 1985 \\
\hline & Bica da Cana/Madeira & 2635,4 & 4327,1 & 1987 \\
\hline & Arieiro/Madeira ${ }^{5}$ & 2620,0 & 3802,1 & 1987 \\
\hline & Ribeiro Frio/Madeira $^{5}$ & 2160,4 & 3143,8 & 1985 \\
\hline & Poiso/Madeira $^{5}$ & 2077,0 & 2978,4 & 1985 \\
\hline \multirow{5}{*}{ AÇORES } & Lagoa do Caiado/Pico ${ }^{6}$ & 4697,8 & 7092,8 & 1987 \\
\hline & Paul/Pico ${ }^{6}$ & 3356,8 & 4651,7 & 1987 \\
\hline & Monte Escuro/São Miguel ${ }^{7}$ & 3197,3 & 4388,6 & 1987 \\
\hline & Espigão Ponte/São Miguel ${ }^{8}$ & 3 194,0 & 7638,0 & 1995 \\
\hline & Lagoa Fogo 3/São Miguel & 3027,8 & 4868,4 & 1977 \\
\hline
\end{tabular}

\begin{tabular}{|c|c|c|c|c|}
\hline \multicolumn{5}{|c|}{$\begin{array}{l}\text { VALORES MEDIOS ANUALES MÁS BAJOS DE LA CANTIDAD DE PRECIPITACIÓN } \\
\text { MENORES VALORES MÉDIOS ANUAIS DA QUANTIDADE DE PRECIPITAÇÃO } \\
\text { LOWEST ANNUAL AVERAGE VALUES FOR PRECIPITATION }\end{array}$} \\
\hline \multirow{2}{*}{$\begin{array}{l}\text { Archipiélago } \\
\text { Arquipélago } \\
\text { Archipelago }\end{array}$} & \multirow{2}{*}{$\begin{array}{l}\text { Lugar } \\
\text { Local } \\
\text { Location }\end{array}$} & \multirow{2}{*}{\begin{tabular}{|c|}
$\begin{array}{c}\text { Media anual } \\
\text { Média anual } \\
\text { Annual average }\end{array}$ \\
(mm)
\end{tabular}} & \multicolumn{2}{|c|}{$\begin{array}{l}\text { Valor más bajo } \\
\text { Menor valor } \\
\text { Lowest value }\end{array}$} \\
\hline & & & $(\mathrm{mm})$ & Año/Ano/Year \\
\hline \multirow{5}{*}{ CANARIAS } & Fuerteventura/Aeropuerto & 104,9 & 31,5 & 1983 \\
\hline & Lanzarote/Aeropuerto ${ }^{9}$ & 109,5 & 45,8 & 1992 \\
\hline & $\begin{array}{l}\text { Las Palmas de Gran Canaria/ } \\
\text { Las Canteras }{ }^{9}\end{array}$ & 115,5 & 34,8 & 1998 \\
\hline & Gando/Gran Canaria $^{9}$ & 136,6 & 43,3 & 1975 \\
\hline & Haría-Orzola/Lanzarote ${ }^{4}$ & 159,4 & 61,1 & 1992 \\
\hline \multirow{5}{*}{ MADEIRA } & Aeroporto/Porto Santo & 361,3 & 144,2 & 1994 \\
\hline & Machico/Madeira $^{5}$ & 518,7 & 258,1 & 1994 \\
\hline & Funchal/Madeira & 596,4 & 310,8 & 1986 \\
\hline & Lugar de Baixo/Madeira & 600,2 & 331,9 & 1994 \\
\hline & Aeroporto de Santa Catarina ${ }^{5}$ & 693,6 & 459,1 & 1981 \\
\hline \multirow{5}{*}{ AÇORES } & Aeroporto/Santa Maria & 729,5 & 444,9 & 1994 \\
\hline & Carapacho/Graciosa ${ }^{10}$ & 786,0 & 583,6 & 1988 \\
\hline & Santa Cruz/Graciosa ${ }^{11}$ & 844,6 & 587,1 & 1984 \\
\hline & Vitoria/Graciosa ${ }^{12}$ & 850,0 & 643,6 & 1984 \\
\hline & Farol Serreta/Terceira ${ }^{13}$ & 881,8 & 303,2 & 1977 \\
\hline
\end{tabular}

\begin{tabular}{|c|c|c|c|}
\hline \multicolumn{4}{|c|}{$\begin{array}{l}\text { VALORES MÁS ALTOS DE LA PRECIPITACIÓN DIARIA (09-09 UTC) } \\
\text { MAIORES VALORES DA QUANTIDADE DE PRECIPITAÇÃO DIÁRIA (09-09 UTC) } \\
\text { HIGHEST VALUES FOR DAILY PRECIPITATION (09-09 UTC) }\end{array}$} \\
\hline \multirow{2}{*}{$\begin{array}{l}\text { Archipiélago } \\
\text { Arquipélago } \\
\text { Archipelago }\end{array}$} & \multirow{2}{*}{$\begin{array}{l}\text { Lugar } \\
\text { Local } \\
\text { Location }\end{array}$} & \multicolumn{2}{|c|}{$\begin{array}{l}\text { Precipitación máxima diaria }(1971-2000) \\
\text { Precipitação máxima diária }(1971-2000) \\
\text { Maximum daily rainfall }(1971-2000)\end{array}$} \\
\hline & & $(\mathrm{mm})$ & Fecha/Data/Date \\
\hline \multirow{5}{*}{ CANARIAS } & San Andrés/El Hierro & 590,0 & $24 / 02 / 1988$ \\
\hline & Sauces-Espigón Atravesado/La Palma & 450,0 & 27/02/1988 \\
\hline & Caldera de Taburiente-Taburiente/La Palma & 399,3 & $10 / 02 / 1978$ \\
\hline & Vilaflor/Tenerife & 358,9 & $11 / 04 / 1977$ \\
\hline & Mazo-Tigalate/La Palma & 350,0 & 17/12/1991 \\
\hline \multirow{5}{*}{ MADEIRA } & Encumeada de São Vicente/Madeira & 277,0 & 09/12/1976 \\
\hline & Bica da Cana/Madeira & 259,6 & 15/12/1976 \\
\hline & Poiso/Madeira & 251,8 & 21/12/1977 \\
\hline & Santo da Serra/Madeira & 247,5 & 20/10/1997 \\
\hline & Bica da Cana/Madeira & 245,9 & 27/03/1985 \\
\hline \multirow{5}{*}{ AÇORES } & Nordeste/São Miguel & 228,1 & 19/11/1975 \\
\hline & Lajes/Aeroporto/Terceira & 225,8 & $03 / 10 / 1974$ \\
\hline & Povoação/São Miguel & 220,0 & 25/12/1989 \\
\hline & Ponta Delgada/Nordela/São Miguel & 209,6 & $01 / 10 / 1998$ \\
\hline & Nordeste/São Miguel & 208,4 & $02 / 09 / 1986$ \\
\hline
\end{tabular}

1 Serie de 26 años completos en el período 1971-2000 Série de 26 anos completos no período 1971-2000 Series of 26 complete years in the period 1971-2000

2 Serie de 29 años completos en el período 1971-2000 Serie de 29 años completos en el período 1971-2000 Serie de 29 años completos en el período 1971-2000 3 Serie de 27 años completos en el período 1971-2000 Série de 27 anos completos no período 1971-2000

Series of 27 complete years in the period 1971-2000

4 Serie de 25 años completos en el período 1971-2000 Série de 25 anos completos no período 1971-2000

Series of 25 complete years in the period 1971-2000

5 Datos de 1971 a 1995

Dados de 1971 a 1995

Data from 1971 to 1995

6 Datos de 1982 a 2000

Dados de 1982 a 2000

Data from 1982 to 2000

Datos de 1979 a 2000

Dados de 1979 a 2000

Data from 1979 to 2000

8 Datos de 1977 a 2000

Dados de 1977 a 2000

Data from 1977 to 2000

Serie de 28 años completos en el período 1971-2000 Série de 28 anos completos no período 1971-2000

Series of 28 complete years in the period 1971-2000

10 Datos de 1973 a 1996

Dados de 1973 a 1996

Data from 1973 to 1996

${ }^{11}$ Datos de 1978 a 2000

Dados de 1978 a 2000

Data from 1978 to 2000

12 Datos de 1975 a 1996

Dados de 1975 a 1996

Data from 1975 to 1996

${ }^{13}$ Datos de 1971 a 1996

Dados de 1971 a 1996

Data from 1971 to 1996 
Normales climatológicas de la precipitación en las Islas Canarias (1971-2000) /

Normais climatológicas da precipitação nas Ilhas Canárias (1971-2000) /

Climate normal values for precipitation in the Canary Islands (1971-2000)

CANARIAS - El Hierro/Aeropuerto, 1975-2000
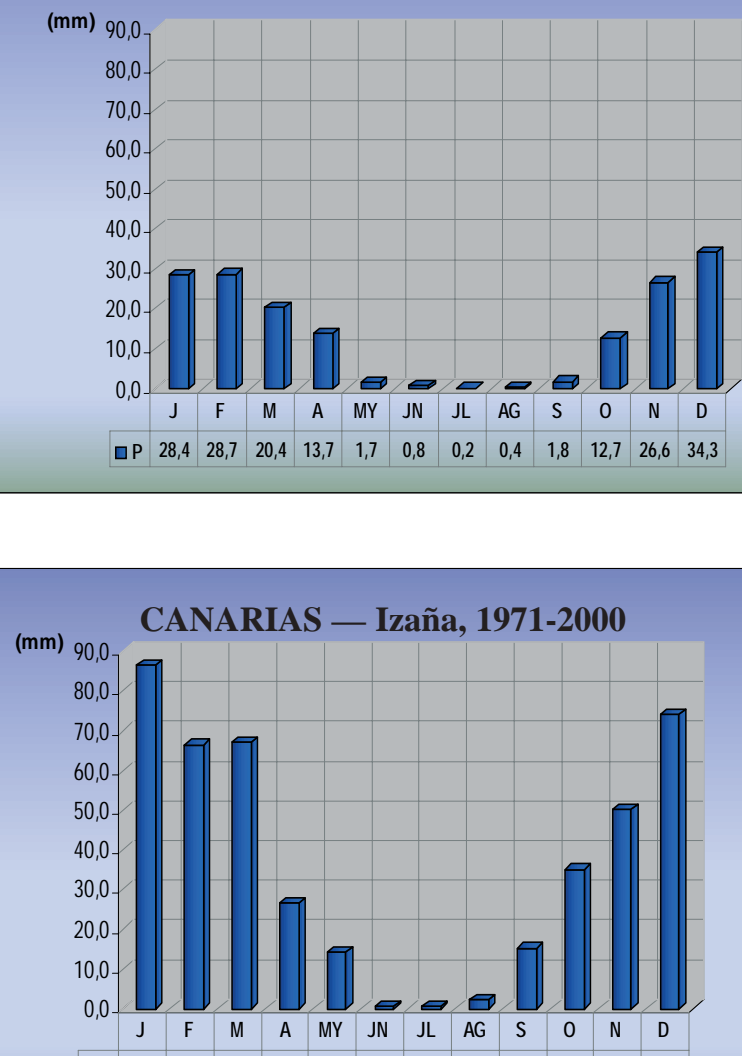

\begin{tabular}{llllllllllllllll}
\hline $\mathrm{P}$ & 86,6 & 66,5 & 67,2 & 26,7 & 14,3 & 0,6 & 0,4 & 2,4 & 15,3 & 35,1 & 50,1 & 74,3
\end{tabular}

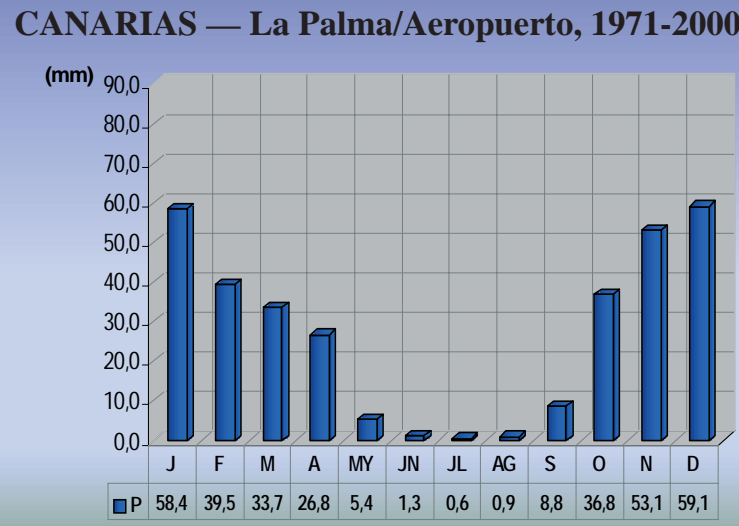

CANARIAS — Las Palmas de Gran Canaria/Gando, 1971-2000

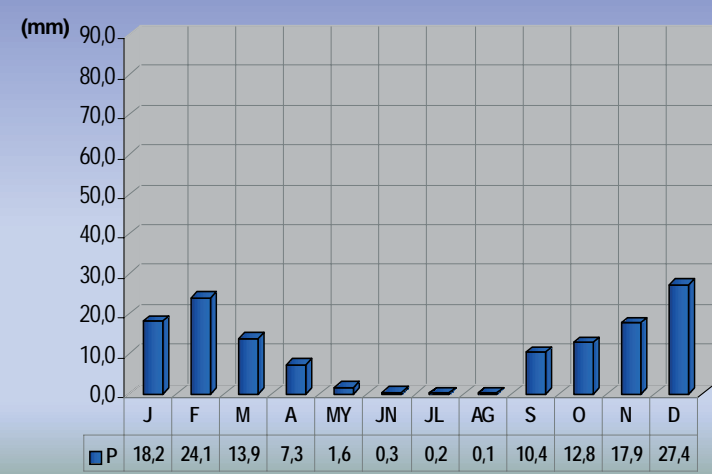

CANARIAS - Fuerteventura/Aeropuerto, 1971-2000
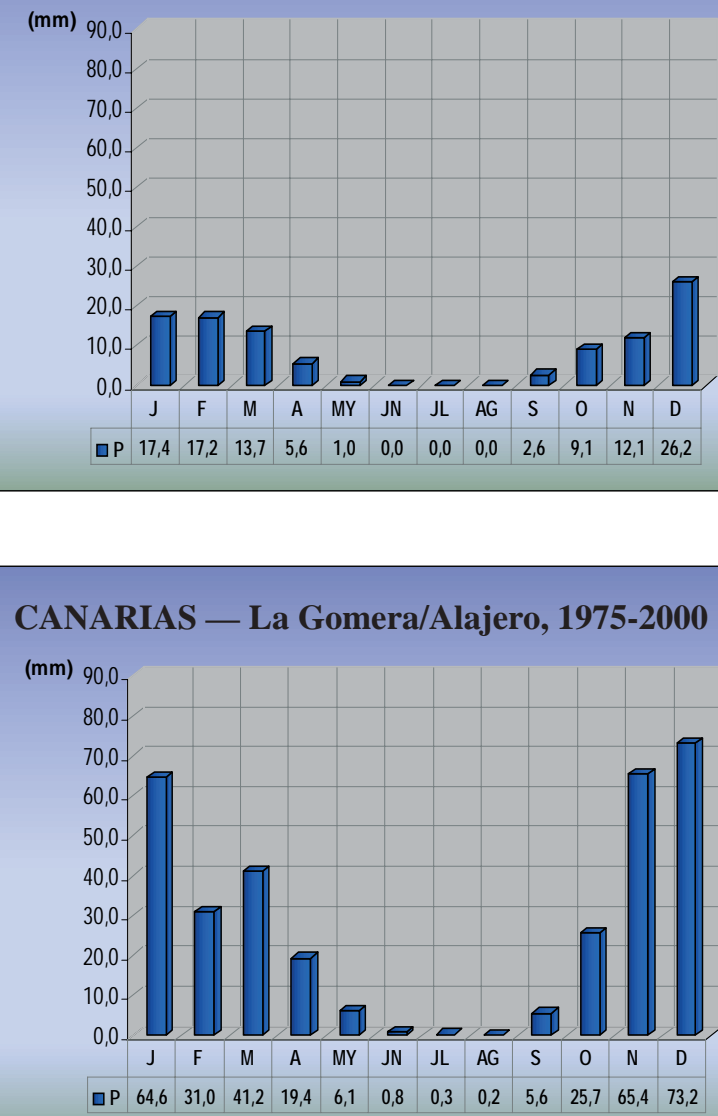

CANARIAS — Lanzarote/Aeropuerto, 1973-2000

(mm) 90,0

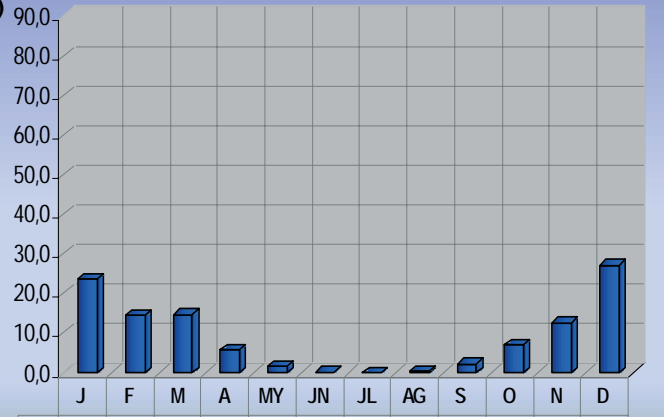

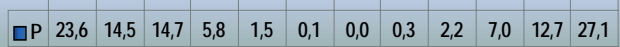

CANARIAS - Santa Cruz de Tenerife, 1971-2000

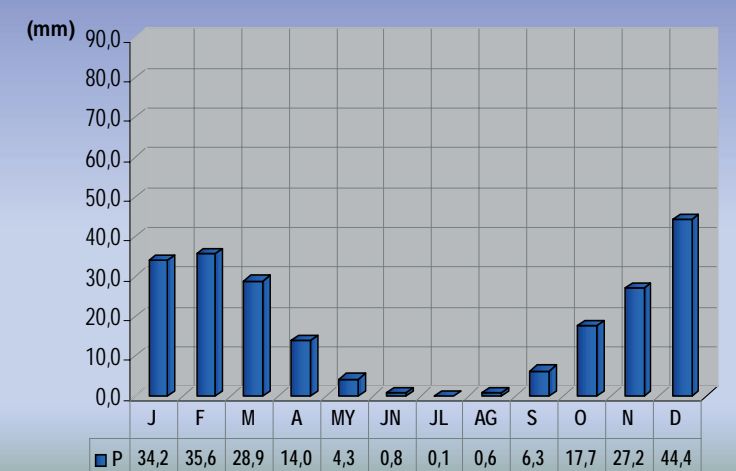

\section{J, F, M, A, MY, JN, JL, AG, S, O, N, D}

Enero, febrero, marzo, abril, mayo, junio, julio, agosto, septiembre, octubre, noviembre, diciembre

Enero, Fevereiro, Março, Abril, Maio, Junho, Julho, Agosto, Setembro, Outubro, Novembro, Dezembro

January, February, March, April, May, June, July, August, September, October, November, December

P Precipitación total media

Média da quantidade de precipitação total

Average total precipitation 
Normales climatológicas de la precipitación en el archipiélago de Madeira (1971-2000) /

Normais climatológicas da precipitação no arquipélago da Madeira (1971-2000) /

Climate normal values for precipitation in the archipelago of Madeira (1971-2000)
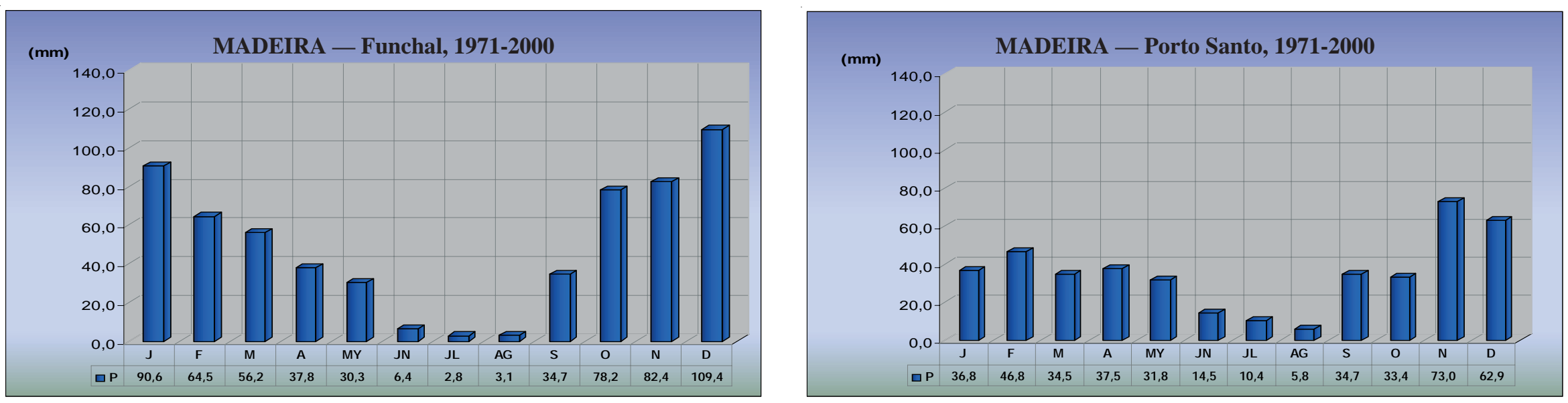

J, F, M, A, MY, JN, JL, AG, S, O, N, D

Enero, febrero, marzo, abril, mayo, junio, julio, agosto, septiembre, octubre, noviembre, diciembre

Enero, Fevereiro, Marco, Abril, Maio, Junho, Julho, Agosto, Setembro, Outubro, Novembro, Dezembro

January, February, March, April, May, June, July, August, September, October, November, December

P Precipitación total media

Média da quantidade de precipitação total

Average total precipitation 
Normales climatológicas de la precipitación en el archipiélago de Azores (1971-2000) /

Normais climatológicas da precipitação no arquipélago dos Açores (1971-2000) /

Climate normal values for precipitation in the archipelago of the Azores (1971-2000)
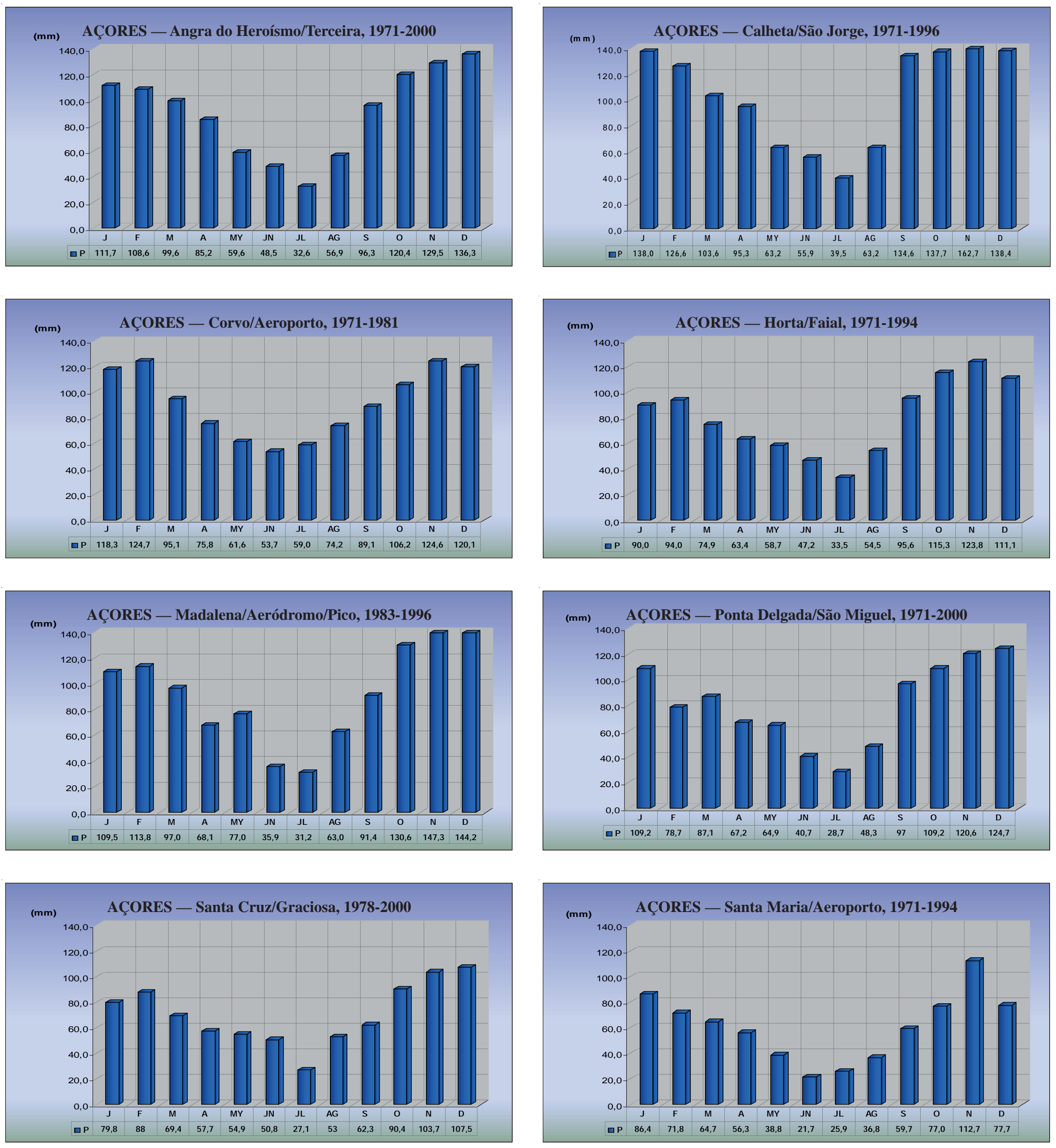

\section{J, F, M, A, MY, JN, JL, AG, S, O, N, D}

Enero, febrero, marzo, abril, mayo, junio, julio, agosto, septiembre, octubre, noviembre, diciembre

Enero, Fevereiro, Março, Abril, Maio, Junho, Julho, Agosto, Setembro, Outubro, Novembro, Dezembro

January, February, March, April, May, June, July, August, September, October, November, December

P Precipitación total media

Média da quantidade de precipitação total

Average total precipitation 
Red pluviométrica para los archipiélagos de Canarias, Madeira y Azores /

Rede meteorológica da precipitação nos arquipélagos das Canárias, da Madeira e dos Açores /

Climatological network for precipitation in the archipelagos of the Canary Islands, Madeira and the Azores

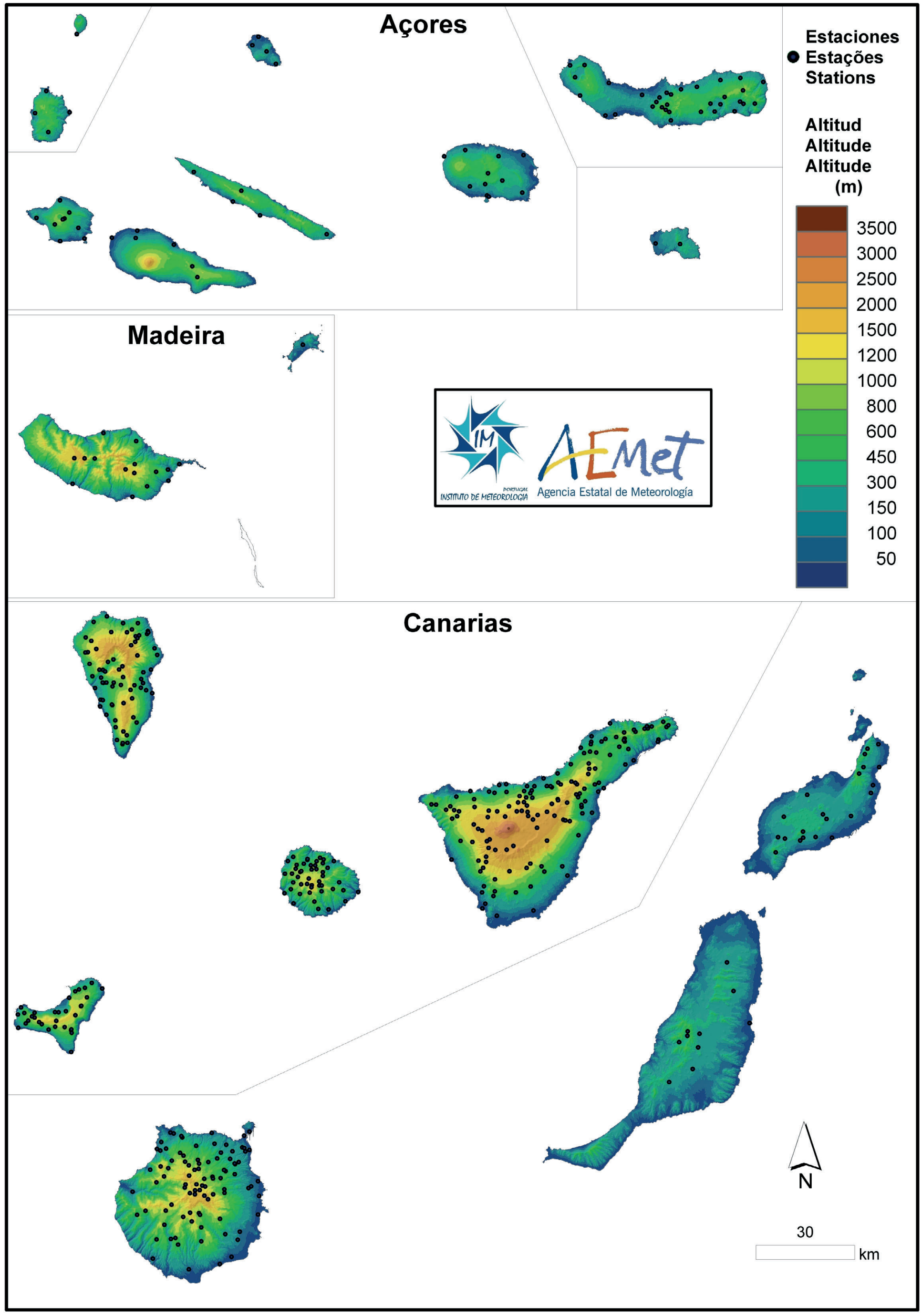

Fig. 59. Red pluviométrica para los archipiélagos de Canarias, Madeira y Azores.

Rede meteorológica da precipitaç̃o nos arquipélagos das Canárias, da Madeira e dos Acores.

Climatological network for precipitation in the archipelagos of the Canary Islands, Madeira and the Azores. 
Precipitación media para los archipiélagos de Canarias, Madeira y Azores (1971-2000) /

Média da precipitação total nos arquipélagos das Canárias, da Madeira e dos Açores (1971-2000) /

Average total precipitation in the archipelagos of the Canary Islands, Madeira and the Azores (1971-2000)

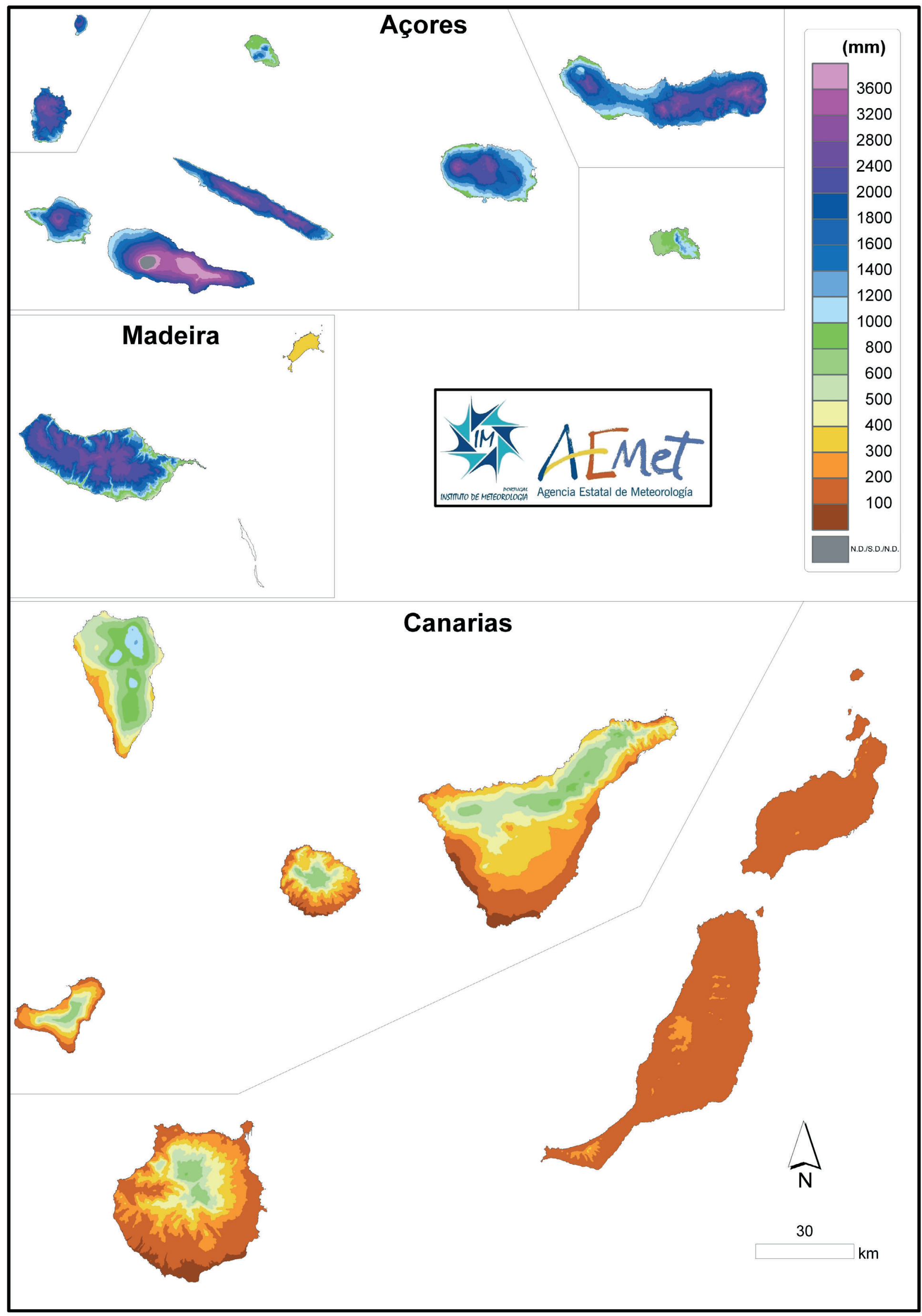

Fig. 60. Precipitación media anual.

Média da precipitação total anual.

Average total annual precipitation. 


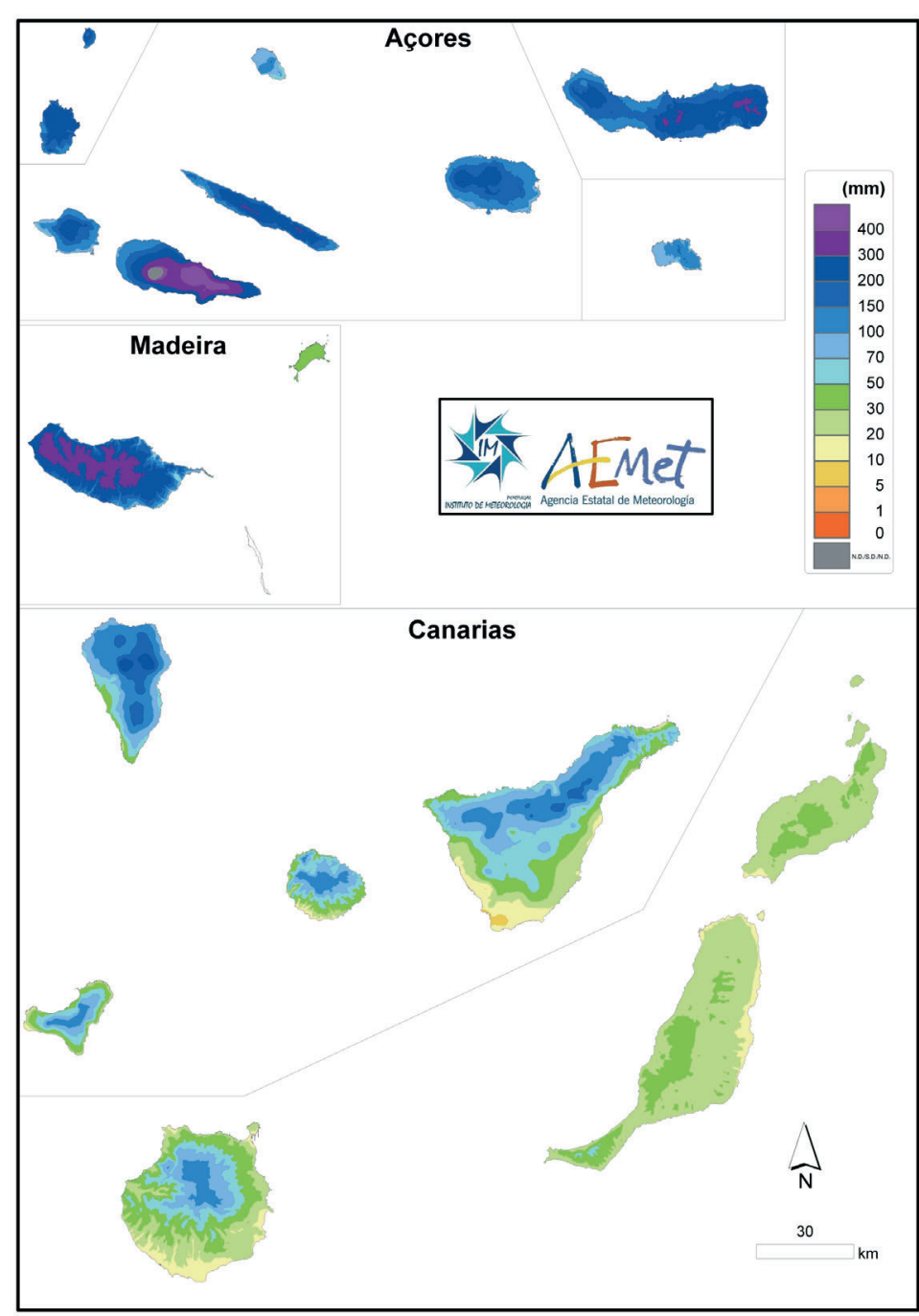

Fig. 61. Precipitación media de enero.

Média da precipitação total em Janeiro.

Average total precipitation in January.

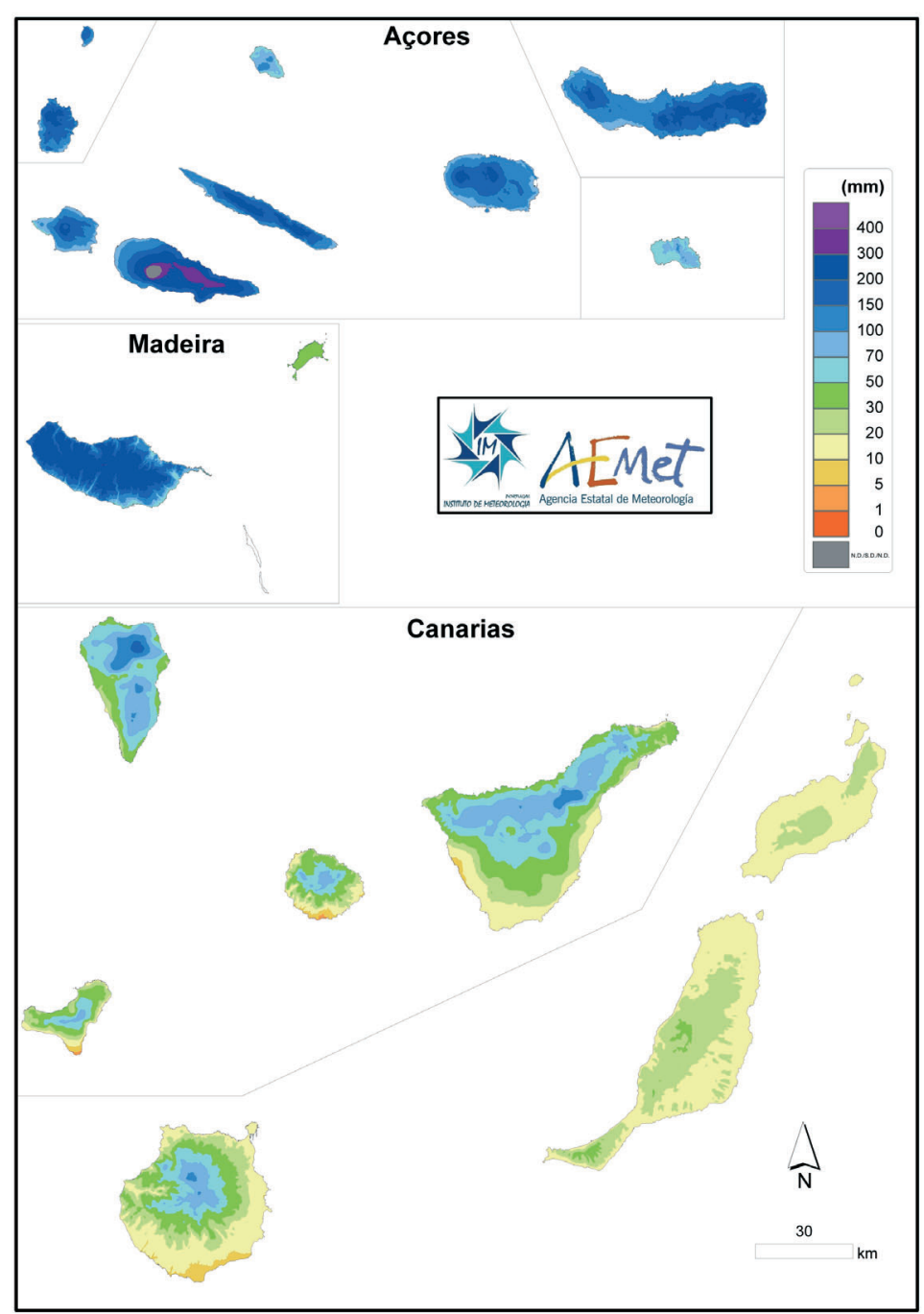

Fig. 63. Precipitación media de marzo.

Média da precipitação total em Março.

Average total precipitation in March.

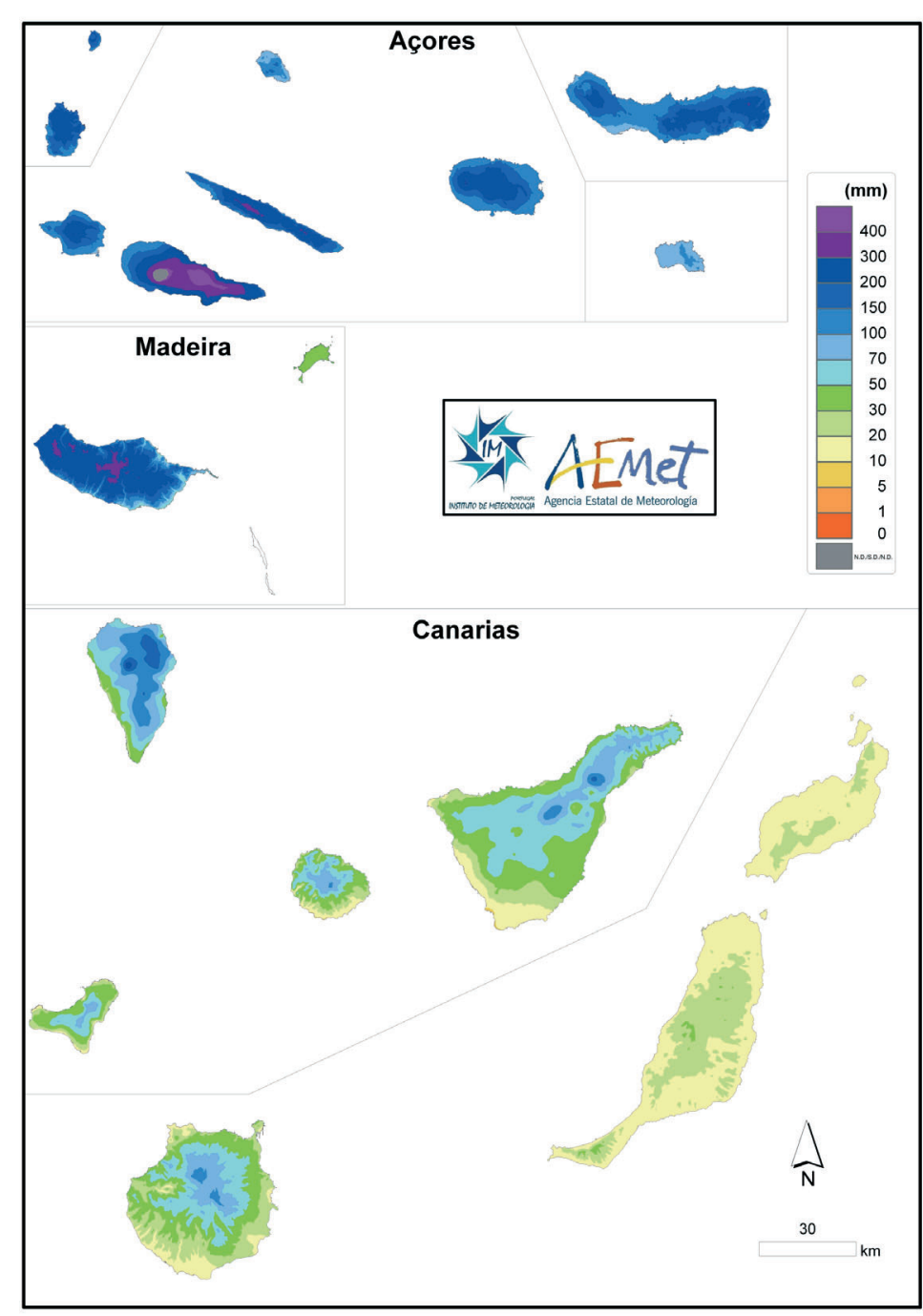

Fig. 62. Precipitación media de febrero.

Média da precipitação total em Fevereiro.

Average total precipitation in February.

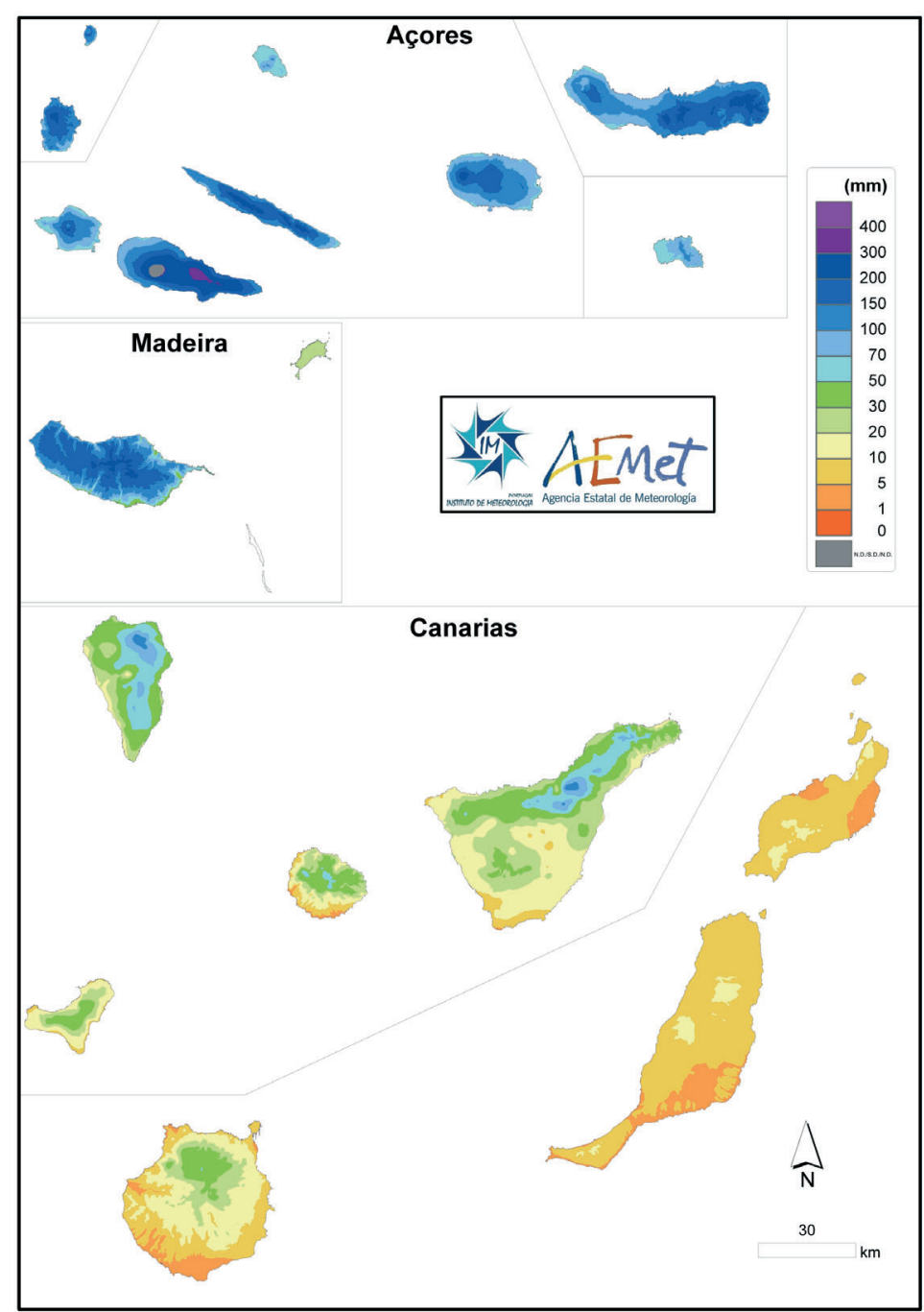

Fig. 64. Precipitación media de abril.

Média da precipitação total em Abril.

Average total precipitation in April. 


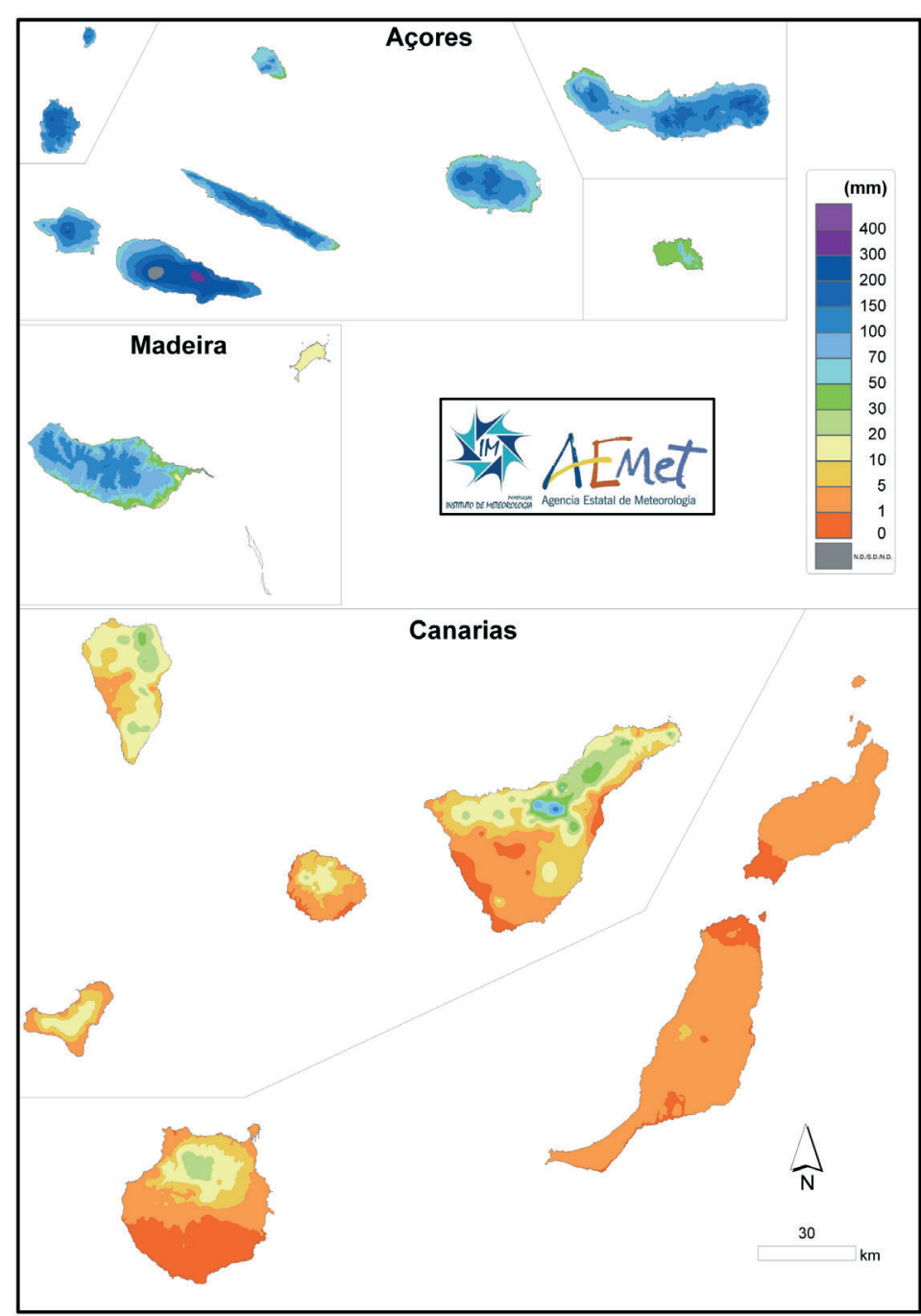

Fig. 65. Precipitación media de mayo.

Média da precipitaç̃o total em Maio.

Average total precipitation in May.

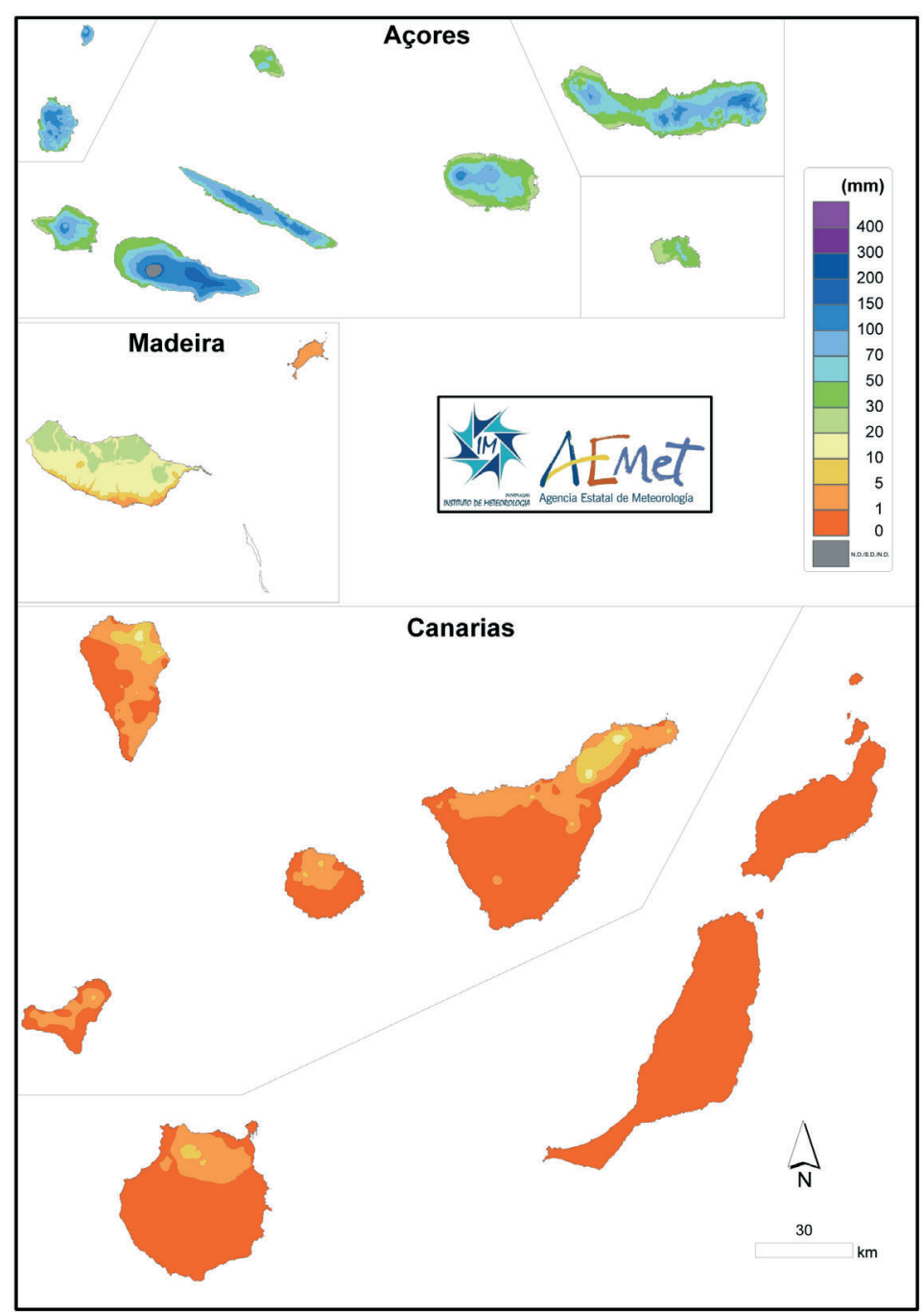

Fig. 67. Precipitación media de julio.

Média da precipitação total em Julho.

Average total precipitation in July.

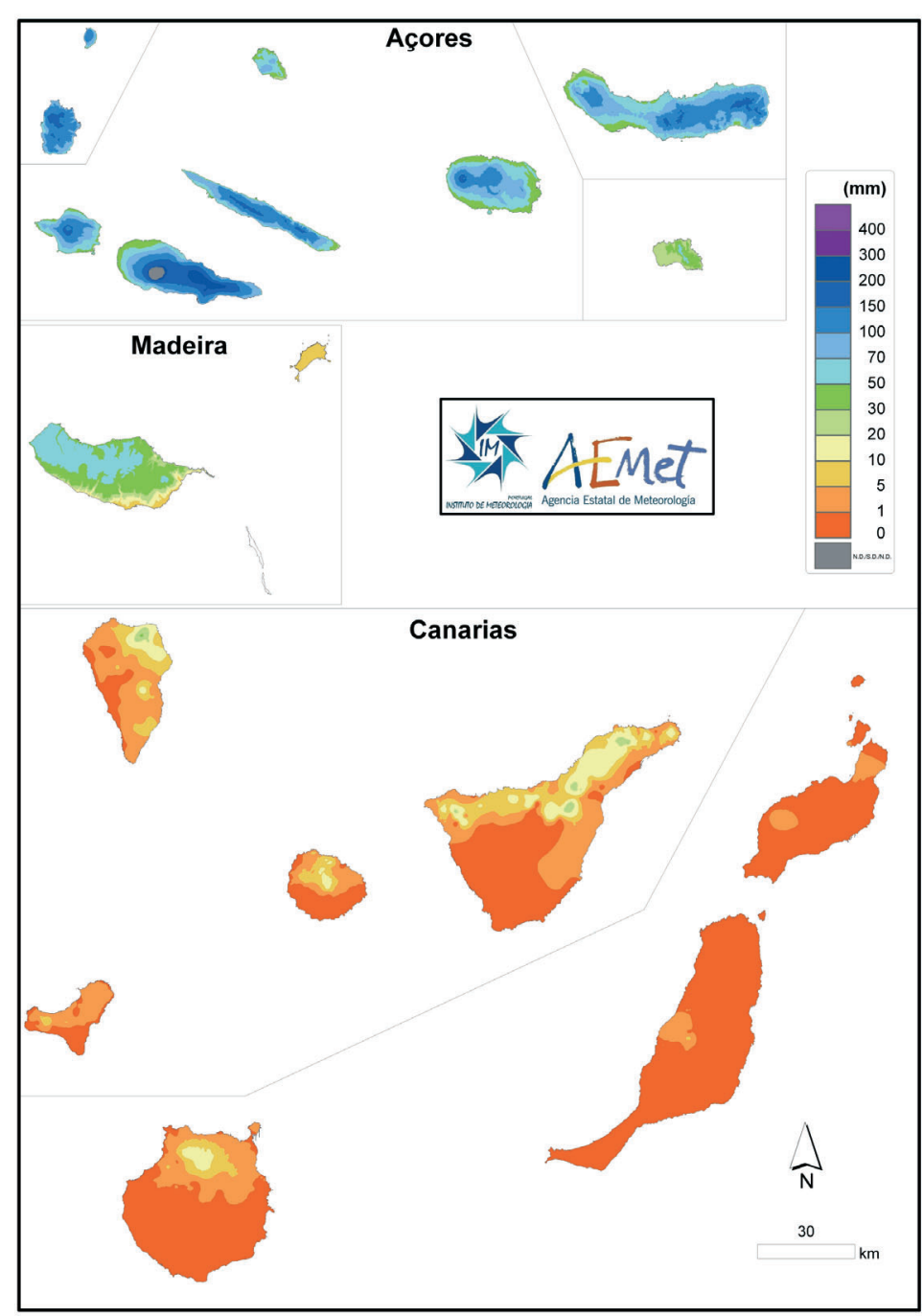

Fig. 66. Precipitación media de junio.

Média da precipitação total em Junho.

Average total precipitation in June.

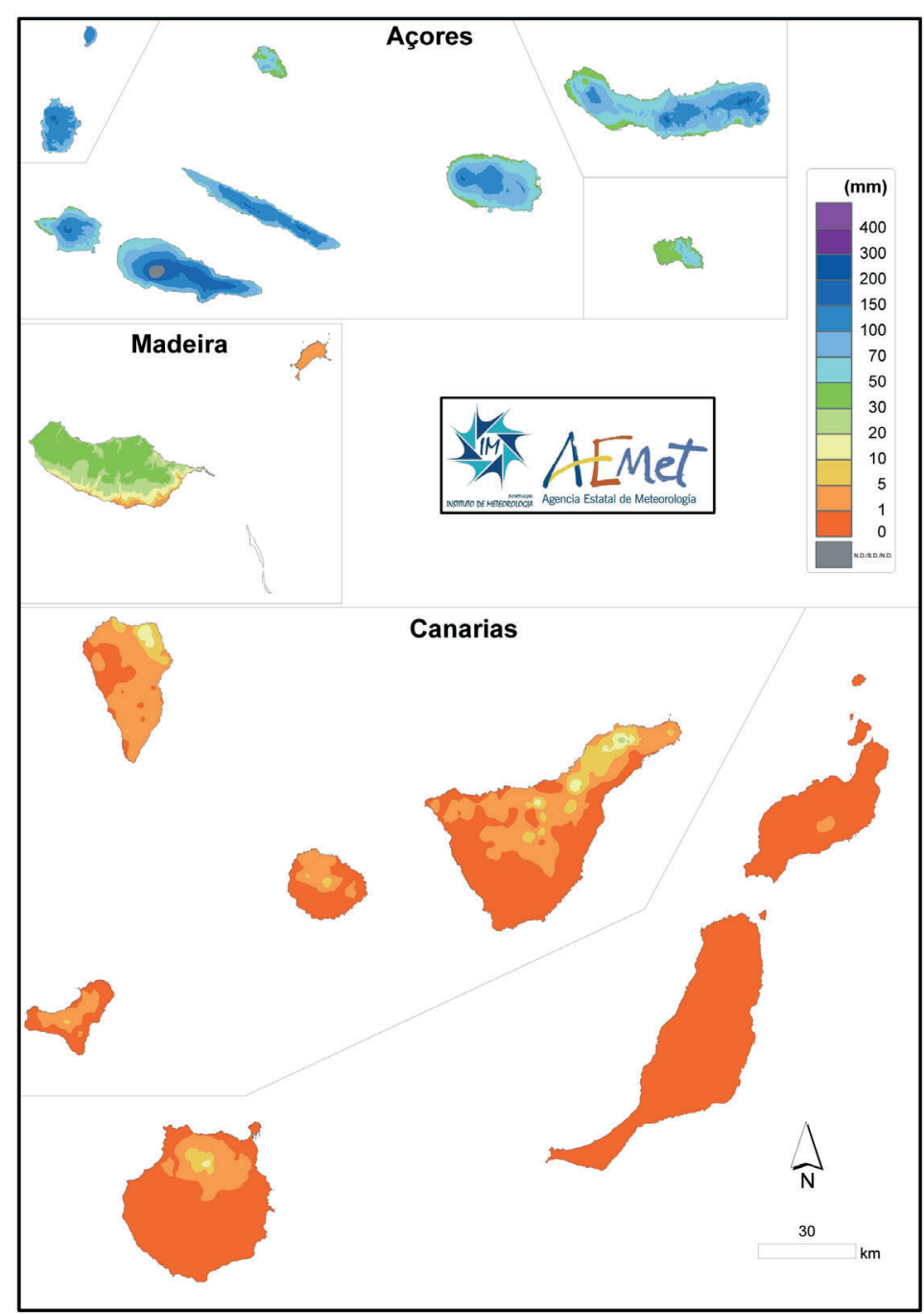

Fig. 68. Precipitación media de agosto.

Média da precipitação total em Agosto.

Average total precipitation in August. 


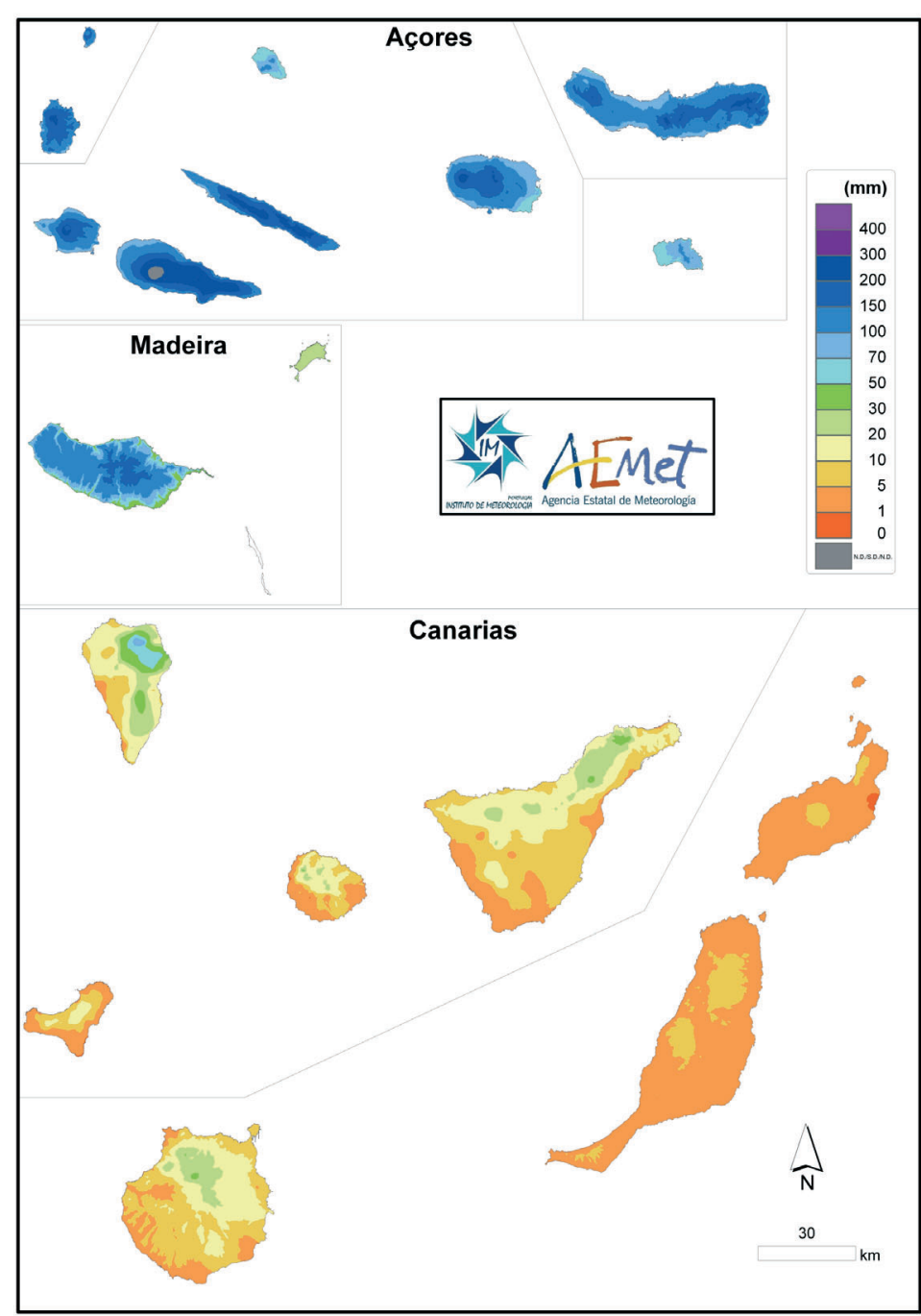

Fig. 69. Precipitación media de septiembre.

Média da precipitação total em Setembro.

Average total precipitation in September.

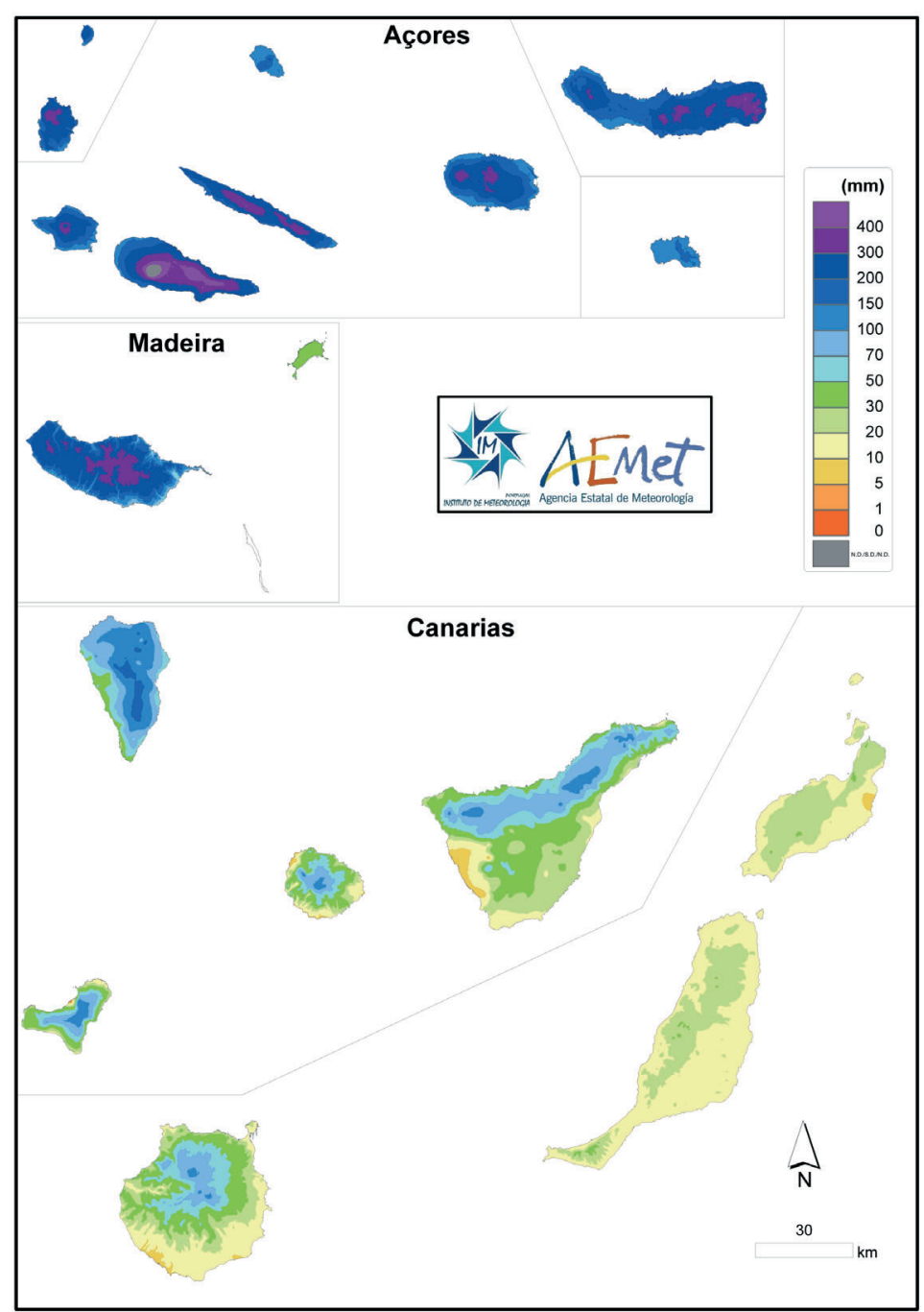

Fig. 71. Precipitación media de noviembre.

Média da precipitação total em Novembro.

Average total precipitation in November.

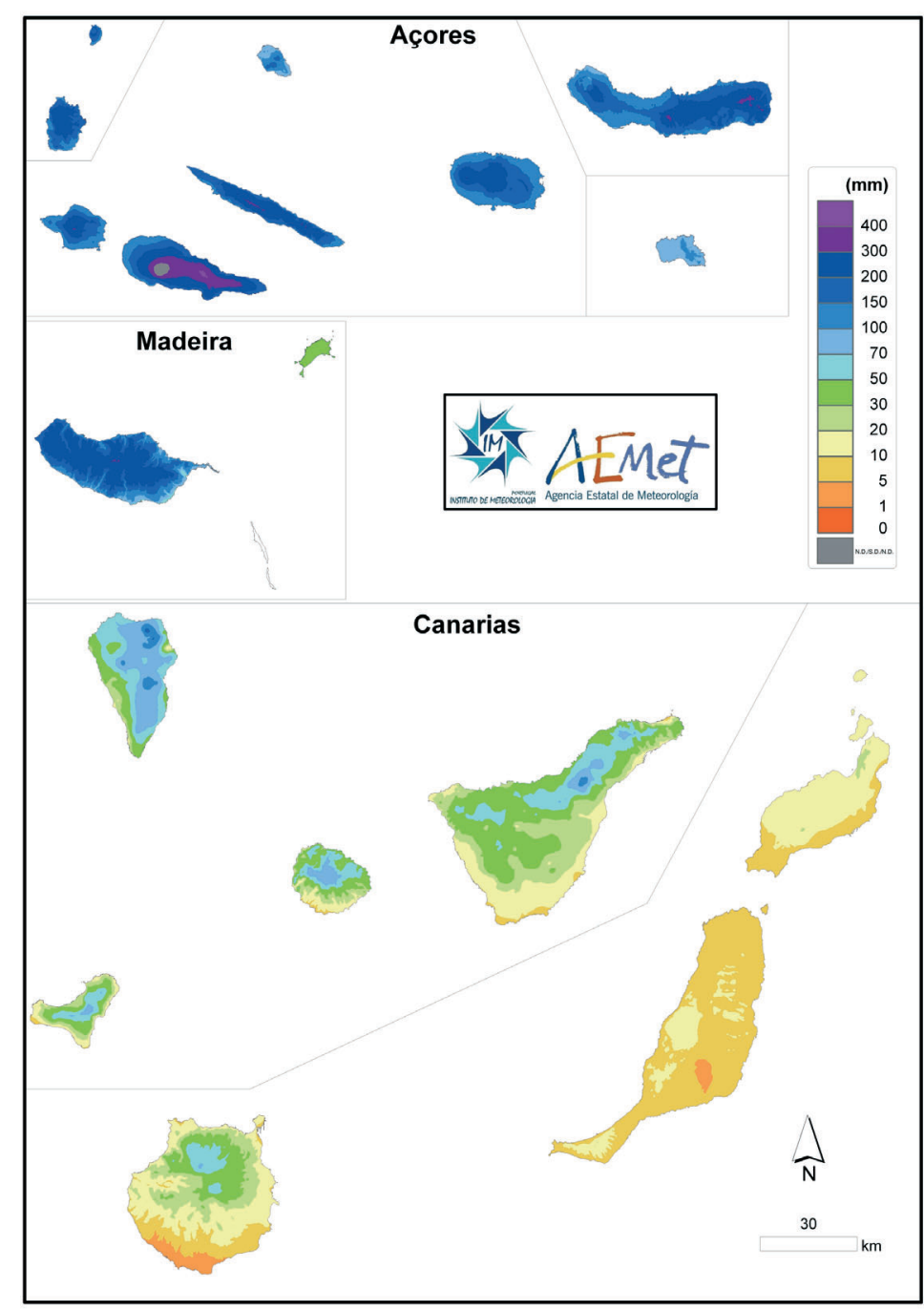

Fig. 70. Precipitación media de octubre.

Média da precipitaç̃o total em Outubro.

Average total precipitation in October.

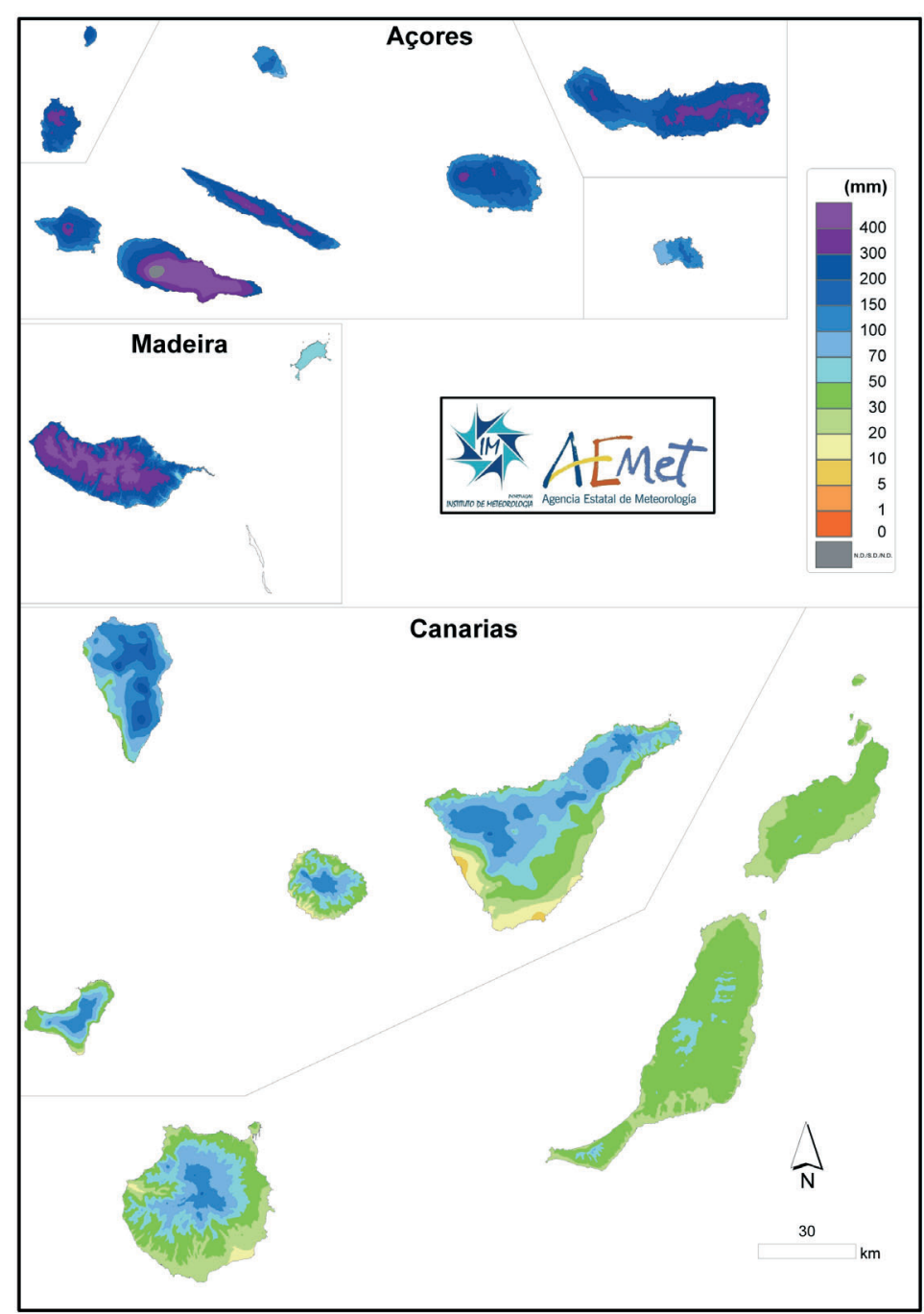

Fig. 72. Precipitación media de diciembre.

Média da precipitação total em Dezembro.

Average total precipitation in December. 
Número medio de días con precipitación superior o igual a 0,1 mm en los archipiélagos de Canarias, Madeira y Azores (1971-2000) / Número médio de dias com precipitação superior ou igual a 0,1 mm nos arquipélagos das Canárias, da Madeira e dos Açores (1971-2000) / Average number of days with precipitation higher of equal to $0.1 \mathrm{~mm}$ in the archipelagos of the Canary Islands, Madeira and the Azores (1971-2000)

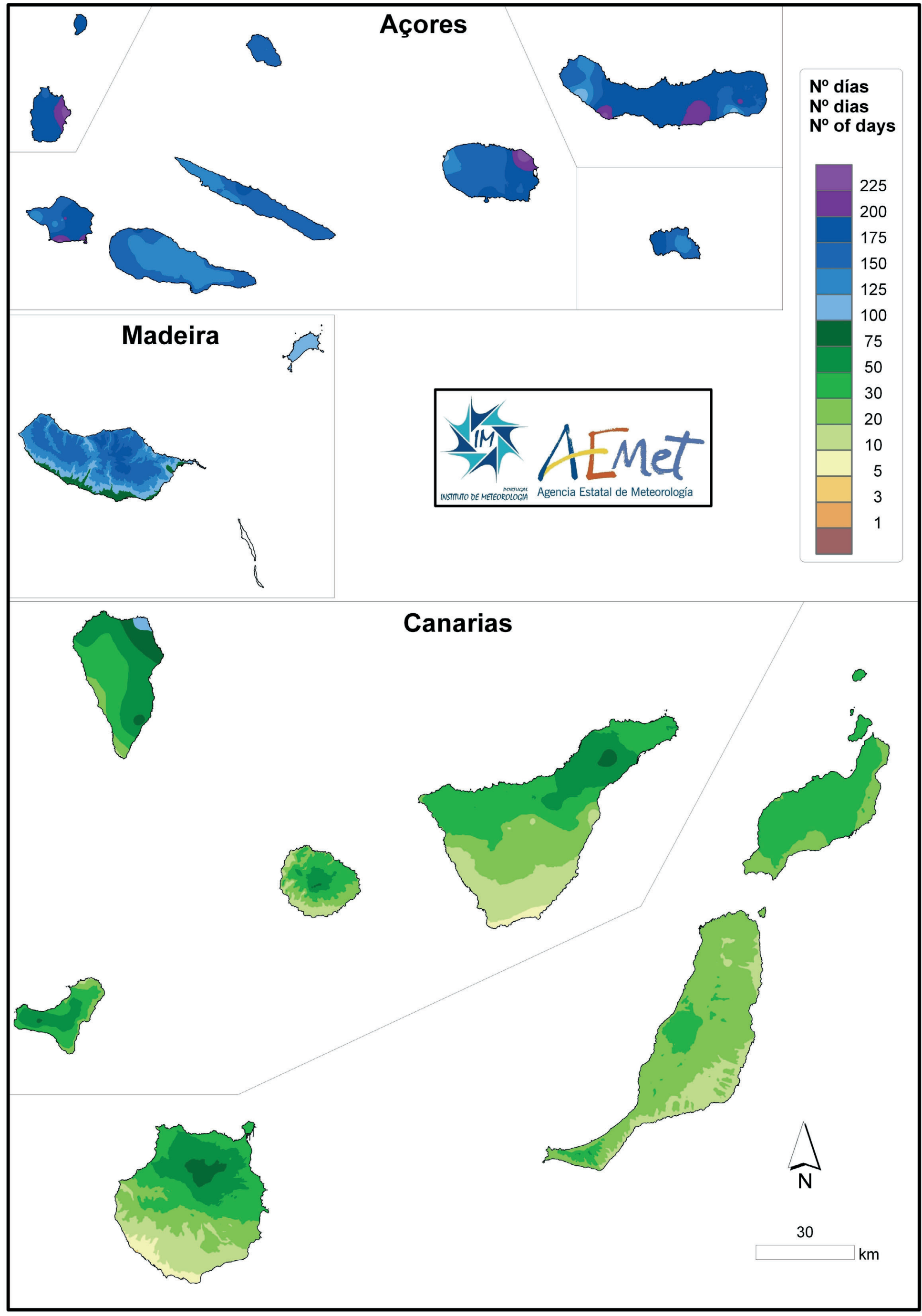

Fig. 73. Número medio anual de días con precipitación $\geq 0,1 \mathrm{~mm}$.

Número médio de dias com precipitação anual $\geq 0,1 \mathrm{~mm}$.

Average number of days with precipitation $\geq 0.1 \mathrm{~mm}$ annual. 
Número medio de días con precipitación superior o igual a 1 mm en los archipiélagos de Canarias, Madeira y Azores (1971-2000) / Número médio de dias com precipitação superior ou igual a $1 \mathrm{~mm}$ nos arquipélagos das Canárias, da Madeira e dos Açores (1971-2000) / Average number of days with precipitation higher of equal to $1 \mathrm{~mm}$ in the archipelagos of the Canary Islands, Madeira and the Azores (1971-2000)

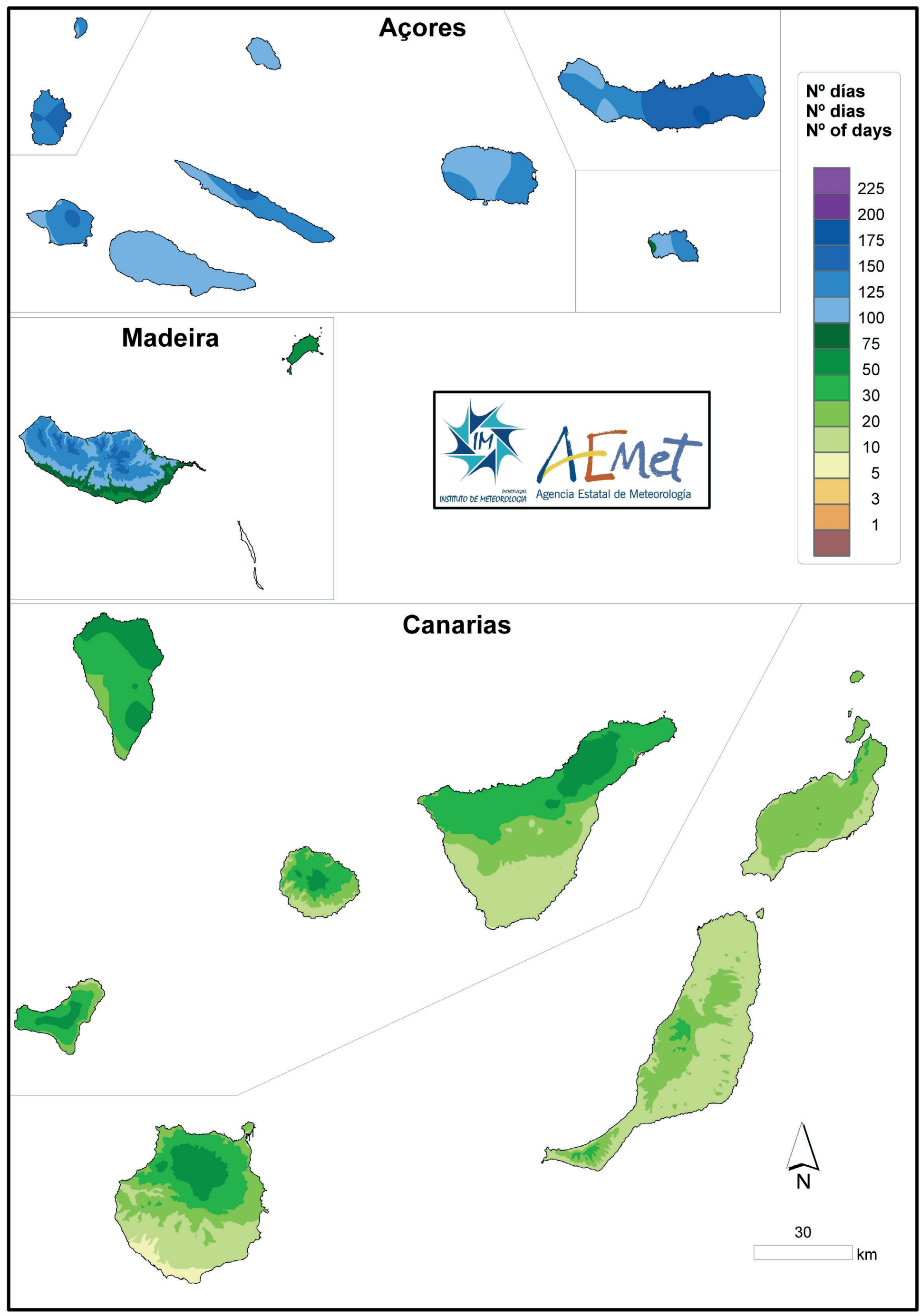

Fig. 74. Número medio anual de días con precipitación $\geq 1 \mathrm{~mm}$.

Número médio de dias com precipitação anual $\geq 1 \mathrm{~mm}$.

Average number of days with precipitation $\geq 1 \mathrm{~mm}$ annual. 
Número medio de días con precipitación superior o igual a $10 \mathrm{~mm}$ en los archipiélagos de Canarias, Madeira y Azores (1971-2000) / Número médio de dias com precipitação superior ou igual a $10 \mathrm{~mm}$ nos arquipélagos das Canárias, da Madeira e dos Açores (1971-2000) / Average number of days with precipitation higher of equal to $10 \mathrm{~mm}$ in the archipelagos of the Canary Islands, Madeira and the Azores (1971-2000)

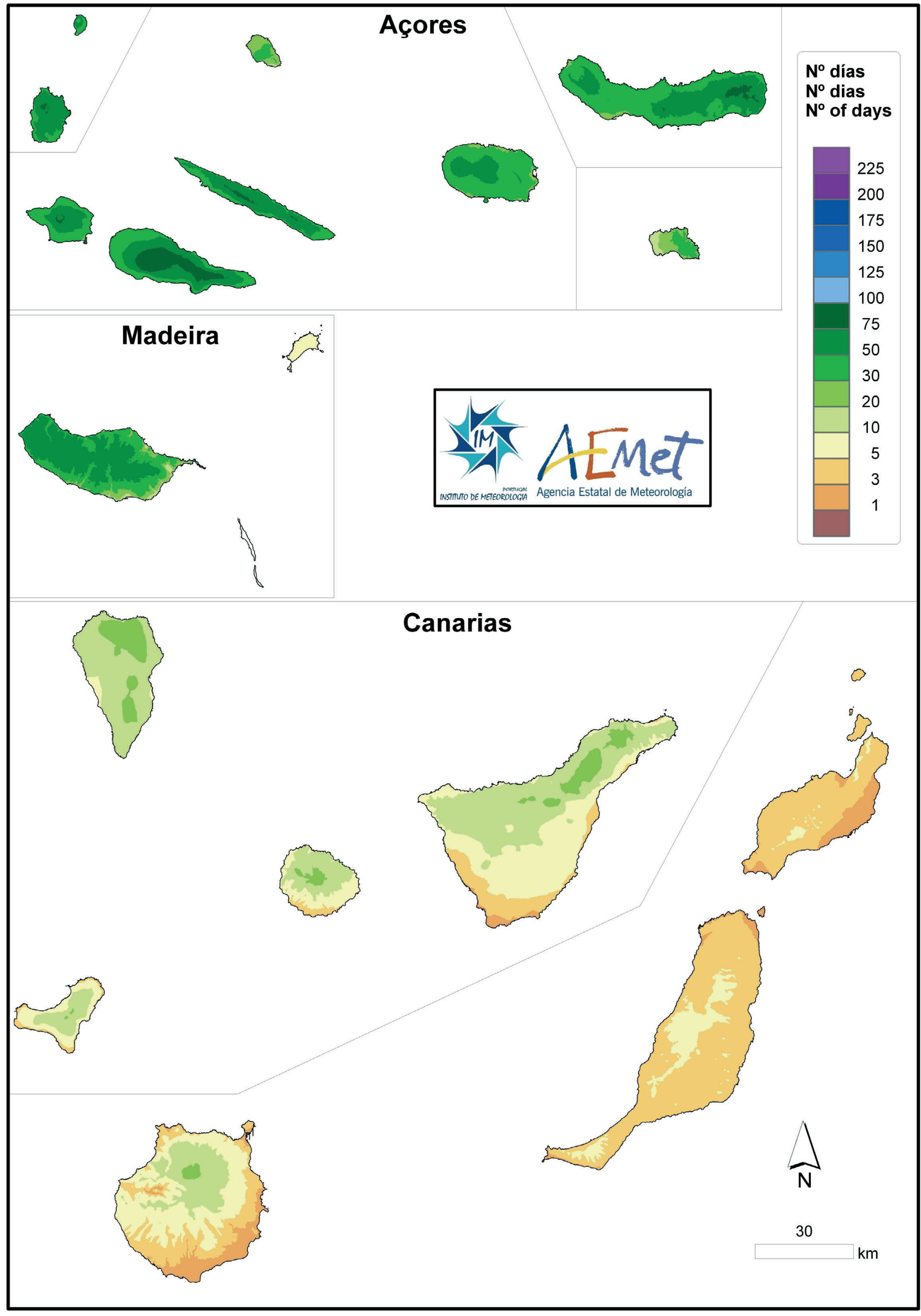

Fig. 75. Número medio anual de días con precipitación $\geq 10 \mathrm{~mm}$.

Número médio de dias com precipitação anual $\geq 10 \mathrm{~mm}$.

Average number of days with precipitation $\geq 10 \mathrm{~mm}$ annual. 
Número medio de días con precipitación superior o igual a $30 \mathrm{~mm}$ en los archipiélagos de Canarias, Madeira y Azores (1971-2000) / Número médio de dias com precipitação superior ou igual a $30 \mathrm{~mm}$ nos arquipélagos das Canárias, da Madeira e dos Açores (1971-2000) / Average number of days with precipitation higher of equal to $30 \mathrm{~mm}$ in the archipelagos of the Canary Islands, Madeira and the Azores (1971-2000)

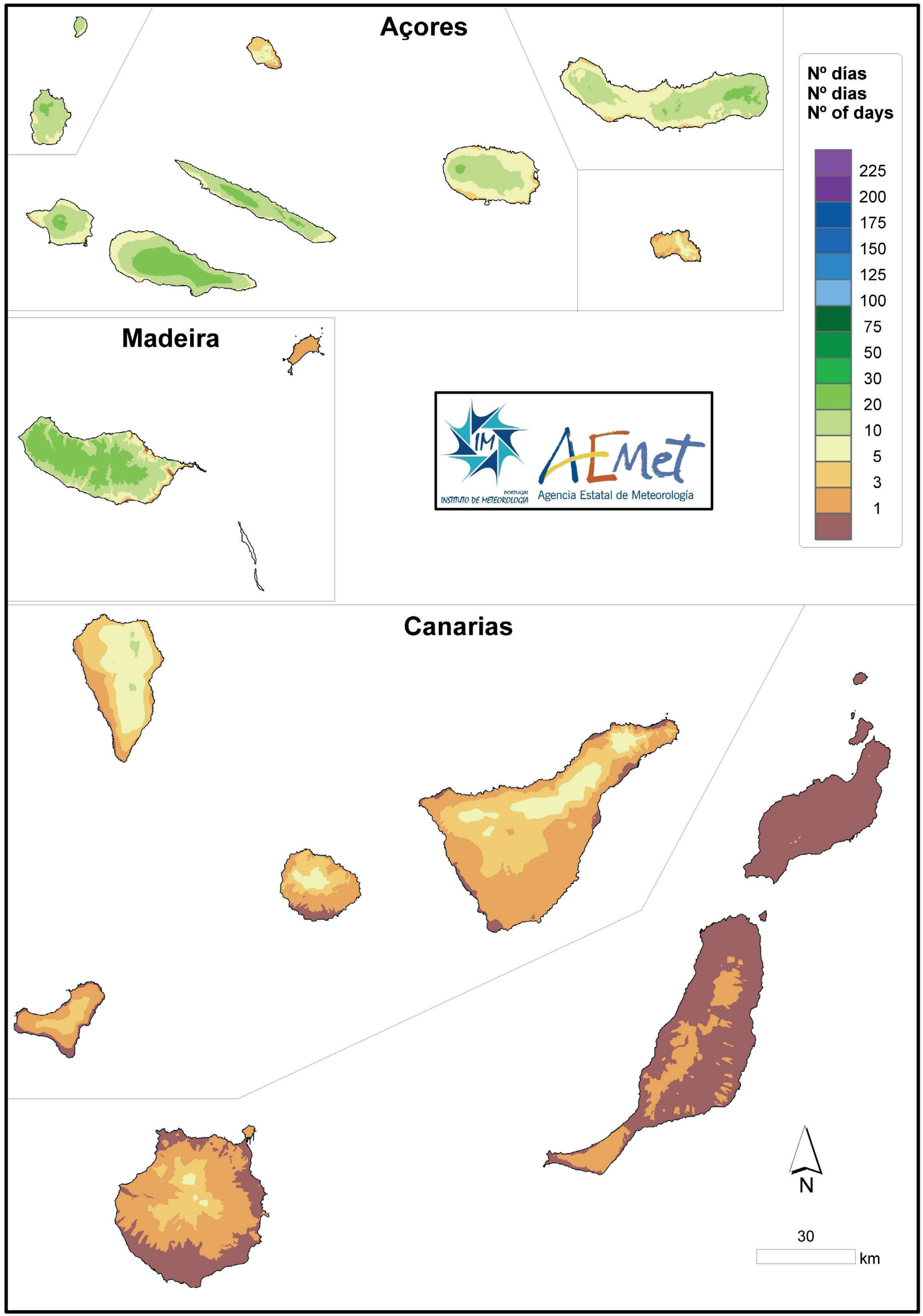

Fig. 76. Número medio anual de días con precipitación $\geq 30 \mathrm{~mm}$.

Número médio de dias com precipitaç̃o anual $\geq 30 \mathrm{~mm}$.

Average number of days with precipitation $\geq 30 \mathrm{~mm}$ annual. 


\section{Referencias}

Agencia estatal de Meteorología (AEMET), Instituto de Meteorologia (I. P.), 2011: Atlas Climático Ibérico - Temperatura del aire y precipitación, 1971-2000.

Azevedo, E. B., 1996: Modelação do Clima Insular à Escala Local. Modelo CIELO aplicado à ilha Terceira. Tese de Doutoramento. Universidade dos Açores, 247 pp.

Azevedo, E. B., L. S. Pereira, B. Itier, 1999: Simulation of local Climate in Islands Environments using a GIS interated model. En: A. Musy, L. S. Pereira \& M. Fritsch (eds.), Emerging Technologies for Sustainable land Use and Water Management (EnviroWater99). Lausanne, Switzerland.

Buch, L. von, 1823: Remarques sur le climat des iles Canaries. Annales Chim. et Phys., Vol 22., pp. 281-304. Paris.

Cuevas, E., 2008: El Centro de Investigación Atmosférica de Izaña, hoy. En: Calendario Meteorológico, 2009, pp. 294-304. Ed. AEMET, Ministerio de Medio Ambiente, Rural y Marino.

Essenwanger, O. M., 2001: General Climatology 1C: Classification of Climates. Elsevier Science.

Font Tullot, I., 1959: El clima de las Islas Canarias. Anuario de estudios atlánticos, n. ${ }^{\circ} 5$. pp. 57-103.

Fragoso Soares Pereira Meirelles, M. G., 2008: Homogeneização de séries temporais de temperatura observadas na região dos Açores. Geração de uma série de referência. Tese de Doutoramento. Ponta Delgada.

Instituto de Meteorologia (I. P.), 2009: Atlas Climatológico de Portugal Continental, 1971-2000: Temperatura do ar e Precipitação. Versão Digital.

Instituto Geográfico Nacional de España, 2004: Atlas Nacional de España, Sección II, Grupo 9: Climatología. Segunda edición.

Instituto Geográfico Português, 2011: Carta Administrativa Oficial de Portugal (CAOP), versão 2011. http://www.igeo.pt/produtos/cadastro/caop/ caop_vigor.htm, accedido el 17-10-2011.

Intergovernmental Panel on Climate Change (IPCC): $h t t p: / / w w w . i p c c . c h / g l o s s a r y / i n d e x . h t m$, accedido el 26-06-2009.

Jarvis, A., H. I. Reuter, A. Nelson, E. Guevara, 2008: Hole-filled SRTM for the globe Version 4, CGIAR-CSI SRTM 90m Database, http:// srtm.csi.cgiar.org, accedido el 09-02-2009.

\section{Referências}

Agencia estatal de Meteorología (AEMeT), Instituto de Meteorologia (I. P.), 2011: Atlas Climático Ibérico - Temperatura do ar e precipitação, 1971-2000.

Azevedo, E. B., 1996: Modelacão do Clima Insular à Escala Local. Modelo CIELO aplicado à ilha Terceira. Tese de Doutoramento. Universidade dos Açores, 247 pp.

Azevedo, E. B., L. S. Pereira, B. Itier, 1999: Simulation of local Climate in Islands Environments using a GIS interated model. Em: A. Musy, L. S. Pereira \& M. Fritsch (eds.), Emerging Technologies for Sustainable land Use and Water Management (EnviroWater99). Lausanne, Switzerland.

Buch, L. vON, 1823: Remarques sur le climat des iles Canaries. Annales Chim. et Phys., Vol, 22. pp. 281-304. Paris.

Cuevas, E., 2008: El Centro de Investigación Atmosférica de Izaña, hoy. Em: Calendario Meteorológico, 2009, pp. 294-304. Ed. AEMET, Ministerio de Medio Ambiente, Rural y Marino.

Essenwanger, O. M., 2001: General Climatology 1C: Classification of Climates. Elsevier Science.

Font Tullot, I., 1959: El clima de las Islas Canarias. Anuario de estudios atlánticos, n. ${ }^{\circ} 5$. pp. $57-103$.

Fragoso Soares Pereira Meirelles, M. G., 2008: Homogeneização de séries temporais de temperatura observadas na região dos Acores. Geração de uma série de referência. Tese de Doutoramento. Ponta Delgada.

Instituto de Meteorologia (I. P.), 2009: Atlas Climatológico de Portugal Continental, 1971-2000: Temperatura do ar e Precipitação. Versão Digital.

Instituto Geográfico Nacional de España, 2004: Atlas Nacional de España, Sección II, Grupo 9: Climatología. Segunda edición.

Instituto Geográfico Português, 2011: Carta Administrativa Oficial de Portugal (CAOP), versão 2011. http://www.igeo.pt/produtos/cadastro/caop/ caop_vigor.htm, acedido em 17-10-2011.

Intergovernmental Panel on Climate Change (IPCC): http://www.ipcc.ch/glossary/index.htm, acedido em 26-06-2009.

Jarvis, A., H. I. Reuter, A. Nelson, E. Guevara, 2008: Hole-filled SRTM for the globe Version 4, CGIAR-CSI SRTM 90m Database, http:// srtm.csi.cgiar.org, acedido em 2009-02-09.

\section{References}

Agencia estatal de Meteorología (AEMET), Instituto de Meteorologia (I. P.), 2011: Iberian Climate Atlas - Air temperature and precipitation, 1971-2000

Azevedo, E. B., 1996: Modelação do Clima Insular à Escala Local. Modelo CIELO aplicado à ilha Terceira. Tese de Doutoramento. Universidade dos Açores, 247 pp.

Azevedo, E. B., L. S. Pereira, B. Itier, 1999 Simulation of local Climate in Islands Environments using a GIS interated model. In: A. Musy, L. S Pereira \& M. Fritsch (eds.), Emerging Technologies for Sustainable land Use and Water Management (EnviroWater99). Lausanne, Switzerland.

Buch, L. vON, 1823: Remarques sur le climat des iles Canaries. Annales Chim. et Phys., Vol, 22. pp. 281-304. Paris.

Cuevas, E., 2008: El Centro de Investigación Atmosférica de Izaña, hoy. In: Calendario Meteorológico, 2009, pp. 294-304. Ed. AEMET, Ministerio de Medio Ambiente, Rural y Marino.

Essenwanger, O. M., 2001: General Climatology 1C: Classification of Climates. Elsevier Science.

Font Tullot, I., 1959: El clima de las Islas Canarias. Anuario de estudios atlánticos, n. ${ }^{\circ} 5$ pp. 57-103.

Fragoso Soares Pereira Meirelles, M. G., 2008 Homogeneização de séries temporais de temperatura observadas na região dos Açores. Geração de uma série de referência. Tese de Doutoramento. Ponta Delgada.

Instituto de Meteorologia (I. P.), 2009: Atlas Climatológico de Portugal Continental, 1971-2000: Temperatura do ar e Precipitação. Versão Digital.

Instituto Geográfico Nacional de España, 2004: Atlas Nacional de España, Sección II, Grupo 9: Climatología. Segunda edición.

Instituto Geográfico Português, 2009: Carta Administrativa Oficial de Portugal (CAOP), versão 2011. bttp://www.igeo.pt/produtos/cadastro/caop/ caop_vigor.htm, accessed 2011-10-17.

Intergovernmental Panel on Climate Change (IPCC): http://www.ipcc.ch/glossary/index.htm, accessed 2009-06-26.

Jarvis, A., H. I. Reuter, A. Nelson, E. Guevara, 2008: Hole-filled SRTM for the globe Version 4, CGIAR-CSI SRTM 90m Database, bttp:// srtm.csi.cgiar.org, accessed 2009-02-09. 
Köppen, W., 1936: Das geographisca System der Klimate. En: Handbuch der Klimatologie, band I, teil C. Edited by Köppen, W. and Geiger. Berlin.

Machado, M. S., 1988: Atividades portuguesas no campo da meteorologia e algumas notas históricas nas etapas do seu desenvolvimento. Monografia de Meteorologia e Geofísica, n. ${ }^{\circ}$ 8. Serviço de Meteorologia, Divisão de Hidrometeorologia, Instituto Nacional de Meteorologia e Geofísica, Lisboa.

ORY, F. DE, 2007: El Observatorio Atmosférico de Izaña en Tenerife (1909-1984): Historia y vida de una institución científica española. Ed. INM, Ministerio de Medio Ambiente. Madrid.

Ory, F. De, M. Palomares, 2004: The observation of the atmosphere in Tenerife island during the last centuries and the mountain observatory in Izaña. Proceedings of ICHM. Polling, Germany, 5-9 July 2004.

Peel, M. C., B. L. Finlayson, T. A. McMahon, 2007: Updated world map of the Köppen-Geiger climate classification. Hydrology and Earth System Sciences, 11, 1633-1644.

Prada, S., 2000: Geologia e Recursos Hídricos Subterrâneos da Ilha da Madeira. Tese de Doutoramento. Universidade da Madeira, Funchal.

Serviço Meteorológico Nacional (SMN), 1955 Açores e Madeira, O Clima de Portugal, Fascículo VIII. Lisboa.

Serviço Meteorológico Nacional (SMN), 1970: Normais Climatológicas do Continente, Açores e Madeira correspondentes a 1931-1960. O Clima de Portugal, Fascículo XIII, 2. ${ }^{a}$ edição, Lisboa.

Sistema Nacional de Informação de Recursos HíDRICOS (SNIRH): http://snirh.pt/index.php, accedido el 27-01-2012.

World Meteorological Organization (WMO), 1989: Calculation of monthly and annual 30-year standard normals. WCDP-No. 10, WMO-TD/No. 341.

World Meteorological Organization (WMO), 1983. Guía de Prácticas Climatológicas. WMO No. 100, 2. a edición.
KöPpen, W., 1936: Das geographisca System der Klimate. Em: Handbuch der Klimatologie, band I, teil C. Edited by Köppen, W. and Geiger. Berlin.

Machado, M. S., 1988: Atividades portuguesas no campo da meteorologia e algumas notas históricas nas etapas do seu desenvolvimento. Monografia de Meteorologia e Geofísica, n. ${ }^{\circ}$ 8. Serviço de Meteorologia, Divisão de Hidrometeorologia, Instituto Nacional de Meteorologia e Geofísica, Lisboa.

Ory, F. DE, 2007: El Observatorio Atmosférico de Izaña en Tenerife (1909-1984): Historia y vida de una institución científica española. Ed. INM, Ministerio de Medio Ambiente. Madrid.

Ory, F. De, M. Palomares, 2004: The observation of the atmosphere in Tenerife island during the last centuries and the mountain observatory in Izaña. Proceedings of ICHM. Polling, Germany, 5-9 July 2004 .

Peel, M. C., B. L. Finlayson, T. A. McMahon, 2007: Updated world map of the Köppen-Geiger climate classification. Hydrology and Earth System Sciences, 11, 1633-1644.

Prada, S., 2000: Geologia e Recursos Hídricos Subterrâneos da Ilha da Madeira. Tese de Doutoramento. Universidade da Madeira, Funchal.

Serviço Meteorológico Nacional (SMN), 1955: Açores e Madeira, O Clima de Portugal, Fascículo VIII. Lisboa.

Serviço Meteorológico NaCional (SMN), 1970: Normais Climatológicas do Continente, Açores e Madeira correspondentes a 1931-1960. O Clima de Portugal, Fascículo XIII, 2.a edição, Lisboa.

Sistema Nacional de Informação de Recursos Hídricos (SNIRH): http://snirh.pt/index.php, acedido em 27-01-2012.

World Meteorological Organization (WMO), 1989: Calculation of monthly and annual 30-year standard normals. WCDP-No. 10, WMO-TD/No. 341.

World Meteorological Organization (WMO), 1983. Guia de Práticas Climatológicas. WMO No. 100, $2^{\underline{a}}$ edição.
Köppen, W., 1936: Das geographisca System der Klimate. In: Handbuch der Klimatologie, band I, teil C. Edited by Köppen, W. and Geiger. Berlin.

Machado, M. S., 1988: Atividades portuguesas no campo da meteorologia e algumas notas históricas nas etapas do seu desenvolvimento. Monografia de Meteorologia e Geofísica, n. ${ }^{\circ}$ 8. Serviço de Meteorologia, Divisão de Hidrometeorologia, Instituto Nacional de Meteorologia e Geofísica, Lisboa.

Ory, F. DE, 2007: El Observatorio Atmosférico de Izaña en Tenerife (1909-1984): Historia y vida de una institución científica española. Ed. INM, Ministerio de Medio Ambiente. Madrid.

Ory, F. De, M. Palomares, 2004: The observation of the atmosphere in Tenerife island during the last centuries and the mountain observatory in Izaña. Proceedings of ICHM. Polling, Germany, 5-9 July 2004.

Peel, M. C., B. L. Finlayson, T. A. McMahon, 2007: Updated world map of the Köppen-Geiger climate classification. Hydrology and Earth System Sciences, 11, 1633-1644.

Prada, S., 2000: Geologia e Recursos Hídricos Subterrâneos da Ilha da Madeira. Tese de Doutoramento. Universidade da Madeira, Funchal.

Serviço Meteorológico Nacional (SMN), 1955: Açores e Madeira, O Clima de Portugal, Fascículo VIII. Lisboa.

Serviço Meteorológico Nacional (SMN), 1970: Normais Climatológicas do Continente Açores e Madeira correspondentes a 1931-1960. O Clima de Portugal, Fascículo XIII, 2. ${ }^{a}$ edição, Lisboa.

Sistema Nacional de Informação de Recursos Hídricos (SNIRH): http://snirh.pt/index.php, accessed 2012-27-01.

World Meteorological Organization (WMO) 1989: Calculation of monthly and annual 30-year standard normals. WCDP-No. 10, WMO-TD/No. 341.

World Meteorological Organization (WMO), 1983. Guide to Climatological Practices. WMO No. 100, 2nd edition. 

El atlas climático constituye un medio de presentar, de forma gráfica, una síntesis de los conocimientos referentes al clima de un país o de una región, que se destina a un gran abanico de usuarios. El presente Atlas Climático pretende describir las principales características climatológicas de los archipiélagos de Canarias, Madeira y Azores, conforme a lo acordado entre los Servicios Meteorológicos de Portugal (IM, I.P.) y de España (AEMet), complementando el Atlas Climático Ibérico editado anteriormente. La información básica utilizada en la elaboración del Atlas ha sido la de las normales climatológicas (valores medios) correspondientes al período 1971-2000. Los elementos climáticos que constan en este volumen son la Temperatura del Aire y la Precipitación, tomando como base los datos de observación de estaciones meteorológicas y pluviométricas de las redes nacionales de Portugal y España.

O atlas climático constitui um meio de apresentar, na forma gráfica, uma síntese dos conhecimentos referentes ao clima de um país ou de uma região, que se destina a uma gama alargada de utilizadores. O presente Atlas Climático pretende descrever as principais características climatológicas dos arquipélagos das Canárias, da Madeira e dos Açores, conforme acordado entre Serviços meteorológicos de Portugal (IM, I.P.) e de Espanha (AEMet), complementando o Atlas Climático Ibérico editado anteriormente. A informação de base utilizada na elaboração do Atlas foi a das normais climatológicas (valores médios) correspondentes ao período 1971-2000. Os elementos climáticos que constam neste volume são a Temperatura do ar e a Precipitação, tendo por base os dados de observação de estações meteorológicas e postos udométricos das redes nacionais de Portugal e Espanha.

A climate atlas is composed of graphically information relating to the climate of a country or region, where this information is to be used for a wide range of different users. This Climate Atlas is intended to describe the main climatological characteristics of the archipelagos of the Canary Islands, Madeira and the Azores, as agreed by the meteorological services of both Portugal (IM, I.P.) and Spain (AEMet), as complement to previously published Atlas Climático Ibérico. The basic information used to produce this Atlas was, in general, taken from climate normals concerning 1971-2000 period. The climate elements included in this volume are air temperature and precipitation, based on the observation data of meteorological stations and udometric stations within the national networks of Portugal and Spain.
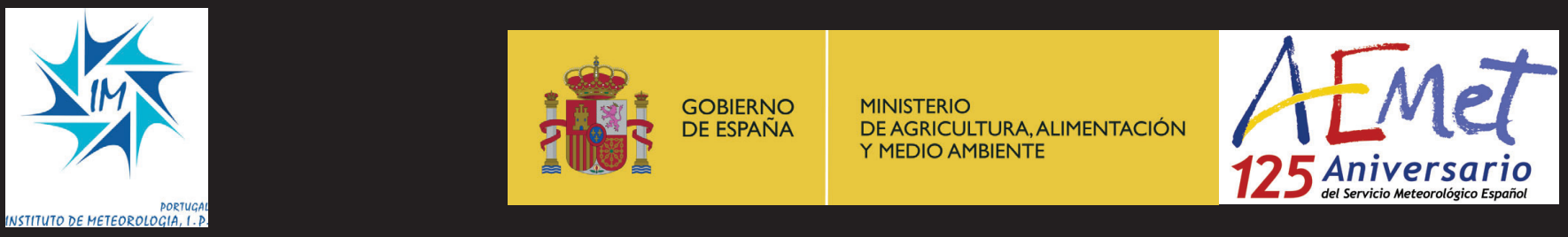